\title{
FEASIBILITY STUDY
}

COMPARISON OF CDAL- AND NUCLEAR-FUELED

ALTERNATIVES FOR PROCESS STEAM

AND BY PRODUCT ELECTRICAL POWER GENERATION

FOR THE

E.I, DU PONT DE NEMOURS \& COMPANY, INCORPORATED

PLANT SITE

VICTORIA，TEXAS 


\section{DISCLAIMER}

This report was prepared as an account of work sponsored by an agency of the United States Government. Neither the United States Government nor any agency Thereof, nor any of their employees, makes any warranty, express or implied, or assumes any legal liability or responsibility for the accuracy, completeness, or usefulness of any information, apparatus, product, or process disclosed, or represents that its use would not infringe privately owned rights. Reference herein to any specific commercial product, process, or service by trade name, trademark, manufacturer, or otherwise does not necessarily constitute or imply its endorsement, recommendation, or favoring by the United States Government or any agency thereof. The views and opinions of authors expressed herein do not necessarily state or reflect those of the United States Government or any agency thereof. 


\section{DISCLAIMER}

Portions of this document may be illegible in electronic image products. Images are produced from the best available original document. 
FEASIBILITY STUDY

COMPARISON OF COAL- AND NUCLEAR-FUELED

ALTERNATIVES FOR PROCESS STEAM

AND BY PRODUCT ELECTRICAL POWER GENERATION

FOR THE

E.I. DU PONT DE. NEMOURS \& COMPANY, INCORPORATED

PLANT SITE

VICTORIA, TEXAS

Report prepared by

POWER SYSTEMS ENGINEERING, INCORPORATED

P. O. Box 19398

Houston, Texas 77024

July, 1978

for

OAK RIDGE NATIONAL IAABORATORY

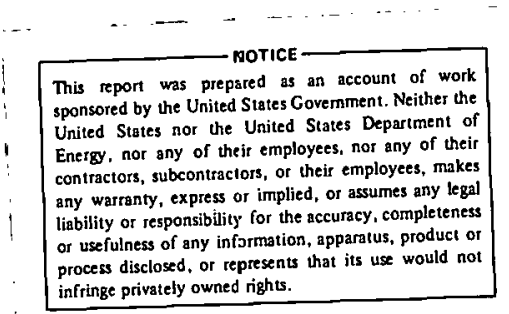

infringe privately owned rights.

\author{
Oak Ridge, Tennessee 37830 \\ operated by \\ UNION CARBIDE CORPORATION \\ for the \\ DEPARTMENT OF ENERGY \\ Contract No: W-7405-eng-26
}

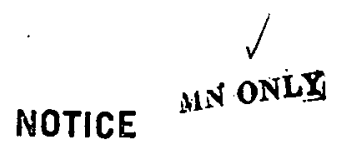

PORTIONS OF THIS REPORT ARE ILLEGIBLE It

has been renroduced from the best available

copy to permit the broadest possible avail: ability. 
This report was prepared as an account of work sponsored by the United States Government. Neither the United States nor the U.S. Department of Energy, nor any of their contractors, subcontractors, or their employees, make any warranty, express or implied, or assumes any legal liability or responsibility for the accuracy, completeness, or usefulness of any information, apparatus, product, or process disclosed, or represents that its use would not infringe privately owned rights.

Printed in the United States of America Available from

National Technical Information Service

Springfield, Virginia. 22151

Price: Printed Copy $\$ 7.25 ;$ Microfiche $\$ 3.00$ 
This feasibility study has been funded by the Department of Energy (DOE) and is the product of the joint efforts of the following participants :

Power Systems Engineering, Incorporated

The Babcock and Wilcox Company, Nuclear Power Generation Division

United Engineers and Constructors, Incorporated

Oak Ridge National Laboratory

E. I. Du Pont De Nemours and Company, Incorporated

PSE acknowledges the participation of the above organizations and appreciates their assistance in the preparation and review of this report. 
TABLE OF CONTENTS

PAGE No.

1.0 EXECUTIVE SUMMARY . . . . . . . . . . . . . . . . . . . . . . 1-1

1.1 . Project Background and Description . . . . . . . . . . . 1-1

1.2 Major Considerations and Conclusions . . . . . . . . . . .1-2

1.2.1 Site Feasibility . . . . . . . . . . . . . . . . . . . . . 1-2

1.2.2 Economic Feasibility . . . . . . . . . . . . . . . 1-3

1.3 Study Scope . . . . . . . . . . . . . . . . . 1-5

1.4 System Designs . . . . . . . . . . . . . . . .1-6

1.4 .1 Nuclear Systems . . . . . . . . . . . . . . 1-6

1.4 .2 Coal Systems . . . . . . . . . . . . . . . . .1-8

1.5 Summary of Recommendations . . . . . . . . . . .1-8

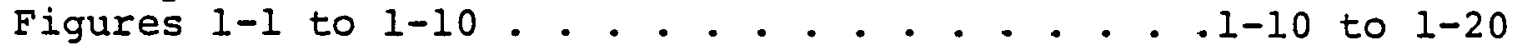

Tables $1-1$ to $1-3 . . . . . . . . . . .1-21$ to $1-22$

2.0 INTRODUCTION. . . . . . . . . . . . . . . . . . 2-1

3.0 SYSTEMS DESCRIPTIONS . . . . . . . . . . . . . . . . . . . . . . I

3.1 Design Requirements . . . . . . . . . . . . . . 3-1

3.1.1. Description of Existing Plant . . . . . . . . . . 3-1

3.1.1.1 General . . . . . . ........... . . . . . . .

3.1.1.2 Historical and Structural Geology . . . . . . . . . . 3-1

3.1.1.3 Site Geology . . . . . . . . . . . . . . . . . . 3-2

3.1.2 Steam and Power Requirements............. . . 3-3

3.1.3 Study Premises ................... . . 3-3

3.2

3.2 .1

Study Systems . . . . . . . . . . . . . . . . .3-4

3.2 .1 .1

3.2 .1 .2

PE-CNSG. . . . . . . . . . . . . . . . . 3-4

3.2 .1 .2 .1

Plant Layout . . . . . . . . . . . . . . . 3-4

3.2 .1 .2 .2

Nuclear Steam Generating System . . . . . . . . 3-6

$3.2 \cdot 1.2 \cdot 3$

Reactor Coolant System . . . . . . . . . . 3-6

3.2 .1 .2 .4

Auxiliary Systems . . . . . . . . : . . . . .3-7

Reactor Plant Instrumentation \& Control System . . 3-8

3.2 .1 .3

Containment . . . . . . . . . . . . . . . .3-8

Refueling, Maintenance, and Inspection . . . . . 3-9

$3.2 \cdot 1.4$

3.2 .1 .4 .1

Secondary/Tertiary Systems . . . . . . . . . 3-10

$3.2 \cdot 1 \cdot 4.2$

3.2 .1 .4 .3

Introduction. . . . . . . . . . . . . . 3-10

Study Cases . . . . . . . . . . . . . . 3-10

3.2 .1 .4 .4

Secondary System Description . . . . . . . . . 3-11

$3.2 \cdot 1 \cdot 4 \cdot 5$

Tertiary Systems . . . . . . . . . . . . . 3-12

3.2 .1 .4 .6

System Control . . . . . . . . . . . . . . .3-12

$3.2 \cdot 1.5$

3.2 .2

3.2 .2 .1

3.2 .2 .2

3.2 .2 .3

$3.2 \cdot 2 \cdot 3.1$

3.2 .2 .3 .2

$3.2 \cdot 2 \cdot 3 \cdot 3$

Condensing Cycle Turbine-Generator System. . . . . 3-14

Construction Techniques . . . . . . . . . . . 3-14

Coal Fueled Steam/Power Plant . . . . . . . . 3-15

Plant Layout. . . . . . . . . . . . . . . 3-15

Study Cases.................. . . 3-16

Design Criteria.. . . . . . . . . . . 3-16

Coal Yard . . . . . . . . . . . . . . 3-16

Boilers . . . . . . . . . . . . . . 3-17

Electrostatic Precipitator... . . . . . . . 3-17 
TABLE OF CONTENTS (Continued)

$3.2 \cdot 2 \cdot 3 \cdot 4$

$3 \cdot 2 \cdot 2 \cdot 3 \cdot 5$

$3.2 \cdot 2 \cdot 3 \cdot 6$

Flue Gas Desulfurization (FGD) System . . . . . . 3-17

3.2 .2 .4

Bottom Ash Disposal System . . . . . . . . . .3-18

Stean Turbine Generator . . . . . . . . . . 3-18

Construction Schedule . . . . . . . . . . . . 3-18

Figures 3-1 to 3-24... . . . . . . . 3-19 to 3-42

Table 3-1. . . . . . . . . . . . . . . . 3-43

4.0 ECONOMICS . . . . . . . . . . . . . . . . . . . . . . 4-1

4.1 Economic Philosophy and Methods . . . . . . . . . 4-1

4.1 .1

4.1 .1 .1

Escalation Schedules . . . . . . . . . . . . .4-2

4.1 .1 .2

General Inflation Escalation Rate....... . . . 4-2

4.1 .1 .3

Construction Labor Escalation Rate . . . . . . . .4-2

4.1 .1 .4

$4 \cdot 1 \cdot 1 \cdot 5$

4.1 .1 .6

4.1 .1 .7

4.1 .1 .8

Construction Material Escalation Rate . . . . . . 4-2

Construction Composite Escalation Rate . . . . . . . .4-2

Operating Labor Escalation Rate . . . . . . . . . . 4-2

Operation Composite Escalation Rate . . . . . . . 4-2

4.1 .2

Fuel (Primary) Escalation Rate.............4-3

$4.1 \cdot 3$

4.1 .4

4.1 .5

4.1 .5

4.1 .7

4.1 .8

4.1 .9

4.1 .10

4.1 .11

4.1 .12

4.1 .13

4.1 .14

4.1 .15

4.1 .16

4.1.16.1

4.1 .16 .2

4.1 .16 .3

4.1 .16 .4

4.1 .16 .5

4.1 .16 .6

4.1 .16 .7

4.1 .16 .8

4.1.16.9

4.1 .16 .10

Number 6 Fuel Oil Escalation Rate... . . . . . 4-3

Federal Income Tax Rate . . . . . . . . . . 4-3

Investment Tax Credit . . . . . . . . . . . 4-3

State Tax (Ad Valorem) Rate . . . . . . . . . 4-3

State Sales Tax Rate... . . . . . . . . . . .4-3

Insurance Rate . . . . . . . . . . . . . . . .4-4

Construction Labor . . . . . . . . . . . . . .4-4

Operations Labor . . . . . . . . . . . . . . .4-4

Plant Availability . . . . . . . . . . . . . .4-4

Plant Factor . . . . . . . . . . . . . . . .4-4

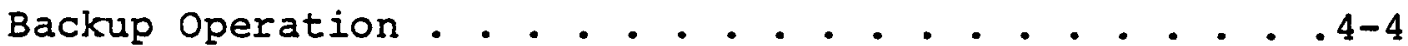

Electrical Power Expense or Credit . . . . . . . .4-5

Working Capital ... . . . . . . . . . . . 4-5

Introductory Expense . . . . . . . . . . . . .4-5

Depreciation . . . . . . . . . . . . . . .4-6

Cash Flow Pro Forma Statement . . . .. . . . . 4-6.

Column (1) Capital Expense . . . . . . . . . .4-6

Column (2) Backup Operating Expense . . . . . . . . 4-6

Column (3) Net Change in Working Capital . . . . . 4-6

Column (4) Investment Cash Flow .......... . 4-6

Column (5) Fuel Expense . . . . . . . . . . 4-6

Collum (6) Operating Expense . . . . . . . . . .4-7

Collimn (7) Total Annual Expense . . . . . . . . 4-7

Column (8) Depreciation . . . . . . . . . . . 4-7

Collum (9) Introductory Expense . . . . . . . . . 4-7

Column (10) Adjusted Operating Expense . . . . . . .4-7

4.1 .16 .11

4.1 .16 .12

4.1 .16 .13

4.1 .16 .14

4.1 .16 .15

Column

Column

(11) Federal Income Tax . . . . . . . . .4-7

(12) Net Operating Expense . . . . . . . . 4-7

Column (13) Investment Tax Credit... . . . . . . 4-8

Column (14) Total Cash Flow . . . . . . . . . 4-8

Column (15) Net Nash Flow . . . . . . . . . 4-8 
4.1.16.16 Column (16) Discounted Cash Flow . . . . . . . . . .4-8

4.1.16.17 Column (17) Net Present Value............ . . 4-8

4.1 .17

4.2

4.2 .1

4.2 .2

4.3

4.3 .1

4.3 .2

$4 \cdot 3 \cdot 3$

4.4

4. 4.1

4.4 .2

$4 \cdot 4 \cdot 2.1$

4.4 .2 .2

4.4 .3

Steam Cost . . . . . . . . . . . . . . . .4-8

Capital Estimates . . . . . . . . . . . . .4-10

Nuclear Plants . . . . . . . . . . . . . . 4-10

Coal Plants................... . .4-13

Fuel Economics . . . . . . . . . . . . . . 4-14

Nuclear Fuel . . . . . . . . . . . . . . 4-14

Coal . . . . . . . . . . . . . . . . . 4-15

Number 6 Fuel oil . . . . . . . . . . . . . .4-16

Operating Economics... . . . . . . . . . . . .4-16

Operating Load and Backup Expense . . . . . . . . .4-16

Plant Availability . . . . . . . . . . . . . 4-17

Nuclear Plants... . . . . . . . . . . . . 4-17

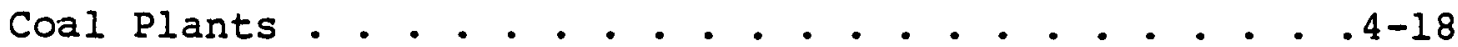

$4 \cdot 4 \cdot 3 \cdot 1$

Annual Operating Expense . . . . . . . . . . 4-19

4.4 .3 .2

Nuclear Plants.

4.5

Coal Plants......................4-19

4.5 .1

Comparative Economics

4.5 .1 .1

Nuclear Plants. . . . . . . . . . . . . . . 4-20

Plants Satisfying Process Steam Temperature

Requirements . . . . . . . . . . . . . . 4-20

$4: 5 \cdot 1.2$

Benchmark Plants

$4-20$

4.5 .2

$4 \cdot 5 \cdot 3$

Coal Plants . . . . . . . . . . . . . . . . . 4-21

Economic Comparison of Optimum Coal and

Nuclear Plants. . . . . . . . ... . . . . . .4-22

4.6

NPV Sensitivity to Variations in Economic

Parameters . . . . . . . . . . . . . . . 4-22

4.6 .1

4.6 .2

NPV Sensitivity to Variation in Capital Investment . 4-23

4.6 .3

4.6 .4

NPV Sensitivity to Primary Fuel Cost . . . . . . . . . 4-23

NPV Sensitivity to Variations in Primary Fuel Cost

Escalation Rate . . . . . . . . . . . . . . .4-23 NPV Sensitivity to Variations in Number 6 Fuel

Oil Costs .. . . . . . . . . . . . . . . .4-23

4.6 .5 NPV Sensitivity to Variations in Number 6 Fuel

Oil Costs Escalation Rate........... . . . . 4-23

4.6 .6

4.6 .7

4.6 .8

NPV Sensitivity to Annual Operating Costs . . . . . .4-24

NPV Sensitivity to Power Credit... . . . . . . . .4-24

NPV Sensitivity to Availability . . . . . . . . . 4 4-24

4.6 .9

Use of Table 4-13

Figures $4-1$ to $4-27$

Table 4-1 to 4-13

. . . . 4-24

$4-25$ to $4-54$

$4-55$ to $4-73$

5.0 CONCLUSIONS

$\cdot \cdot \cdot \cdot \cdot \cdot \cdot 5-1$

5.2

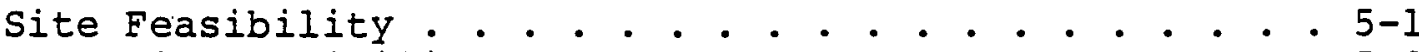

5.3

Economic Feasibility . . . . . . . . . . . . . 5-2

Technical Feasibility . . . . . . . . . . . . . 5-3

6.0 RECOMMENDATIONS . . . . . . . . . . . . . . . . . . 6-1

REFERENCES 


\section{ABSTRACT}

The purpose of the study was to evaluate the technical and economic feasibility of a small., (3.65 MWt) nuclear reactor for supplying process steam and electricity as a replacement for energy sources using increasingly scarce natural gas or oil. The Du Pont Chemical Plant Site at Victoria, Texas, was chosen as representative of industrial installations that require sizeable amounts of process steam and electricity. For comparison purposes conventional coal-fired boilers were also evaluated.

It was determined that both nuclear- and coal-based process energy supply systems are technically feasible. For the specific steam/electricity demands a the reference site, the coal-fired plant proved to be economically more attractive than the nuclear units. For an application requiring a base-loaded supply of saturated steam, utilizing full. reactor capacity, the nuclear option appears competitive for coal costing $\$ 37 /$ ton in 1978 dollars. 


\subsection{EXECUTIVE SUMMARY}

\subsection{Project Background and Description}

The work discussed in this report has been sponsored by the Department of Energy (DOE). Participants in the cooperative study included Oak Ridge National Laboratory (ORNL); Power Systems Engineering, Inc. (PSE), Houston, Texas; The Babcock and Wilcox Compary, Nuclear Power Generation Division ( $B \& W)$, Lynchburg, Virginia; and United Engineers and Constructors, Inc. (UE\&C), Philadelphia, Pennsylvania. PSE acted as the study coordinator under subcontract ORNL-Sub-7257 and was supported by ORNL, B\&W, and UE\&C.

The present study is an outgrowth of previous DOE - sponsored studies by ORNL, $B \& W$, and UE\&C, in which the generalized economic and commercial feasibility of utilizing small nuclear reactors to provide industrial process steam was investigated (References 1 and 2). The work being reported herein addresses the specific siting, technical, and economic feasibility of utilizing B\&W's Process Energy Consolidated Nuclear Steam Generator ( $P E-C N S G)$ design as a process steam generator for an existing chemical facility. To provide a comparative basis for evaluating the economic feasibility of the PE-CNSG, the study included a comparable site, technical and economic evaluation of coal-fired process steam generation systems. Coal was chosen as the alternative fuel because it is the most abundant domestic fuel resource and because of the great emphasis being placed on its use.

The Du Pont plant site at Victoria, Texas, was chosen as one of three to be studied in the Gulf Area (References 3 and 4). This site was chosen as representative of large industrial process steam users and because it appeared to be suited for both the PE-CNSG and the coal applications. The study was designed to yield results applicable at numerous sites. In the course of the study, Du Pont provided such site, technical and economic inputs as were required in order to generate a complete and meaningful feasibility evaluation for the specific site under study. The DuilPont participation was contributed by Du Pont. Without this support on the part of Du Pont, winich amounted to approximately four man-months, this study would not have been possible.

This section is a summary of the work accomplished and summarizes information contained in more detail in later sections of the report.

The stated objective of the work performed was the evaluation of the site, technical and economic feasibility of utilizing a small nuclear reactor as a process steam generator at a specific industrial site. Generalized feasibility has previously been investigated for the hypothetical "Middletown, U.S.A." site for the B\&W PE-CNSG nuclear system. (Reference 2). In order to demonstrate economic feasibility, the nuclear system must be compared to an alternative steam supply system, either an existing system at the site, or a new system. Since Du Pont currently uses natural gas or fuel oil at its victori-a site, and since neither of these fuels is as domestically abundant as coal, it was decided to evaluate a new coal-fired facility as the alternative to the 


\subsection{Project Background and Description - (Continued)}

PE-CNSG. B\&W, UE\&C, and ORNL provided all site evaluations, technical information, and cost estimates for three candidate nuclear systems plus two benchmark systems. The benchmark systems were studied to aid in evaluating the economic impact of the addition of electrical generation and oil-fired superheating to the basic nuclear steam generator system. FSE's scope of work included estimating fuel-oil fired superheat systems for those nuclear plant system options requiring them, as well as the development of the coal plant configuration and cost estimates for comparison with the nuclear plants. The eight coal plant designs were developed, estimated and analyzed, including four highsulfur Illinois coal-fired and four low-sulfur Wyoming coal-fired plants. PSE then performed the economic evaluations of the coal/nuclear alternatives using net present value (NPV) cash flow economic methods.

The base date for all economic comparisons is January 1, 1978. Cash flows reported in current dollars are escalated beyond January 1, 1978. Where discount rates have been applied, the "present" date is January 1, 1978. The study assumes all equity funding, i.e., no..cost of capital or debt service has been considered.

\subsection{Major Cons-derations and Conclusions}

\subsubsection{Site Feasibility}

The preliminary site feasibility study has been based on existing geological, topographic, meteorological, population, and seismic information supplied by Du Pont for their Victoria, Texas Plant site. The study failed to disclose any condition that would preclude the construction and operation of either the PE-CNSG or coal-fired process steam systems. There was no attempt made to generate new site information, and the conclusions infer no assurance that in-depth site studies will bear out these preliminary conclusions. The available data indicate that this site is probably quite well suited for nuclear as well as for fossil-fueled installations of the type studied. Final site suitability would be subject to detailed study.

Figure 1-1 shows the PE-CNSG plant layout which has been selected for the study. Figure 1-2 presents the coal plant layout. The study plants were located in areas designated by Du Pont as acceptable. They are not necessarily optimum locations, but are judged to be representative and feasible locations. 


\subsubsection{Economic Feasibility}

A total of five. PE-CNSG plant configurations and eight coal plant configurations were evaluated on the basis of economics tailored to the Victoria plant site. Each nuclear plant and each coal plant was compared on the basis of net present value (NPV). over a 30 year total project life in order to arrive at an optimum pair of plants from which to make the final economic choice. No attempt has been made to compare these study plants with existing facilities.

Because of the seven year construction period for the nuclear plants and the four year period for the coal plants, economic comparisons were made under two sets of assumptions regarding project start times. In both comparisons, the nuclear plants are assumed to begin construction on January 1, 1978. Coal plant economics were generated first under the assumption that the coal plants start construction concurrently with the nuclear plants. An additional set of coal plant economics was generated under the assumption that the coal plants were to start operation concurrently with the nuclear plants (i.e., start construction on January 1,1981 ). The major economic impact that occurs as a result of the difference in nuclear and coal plant constuction time requirements is the penalty incurred by the nuclear plants for the number 6 fuel oil equivalent of the steam required by the user during the last three years of nuclear plant construction for the cases where the coal plants go into operation three years prior to the nuclear plants. The removal of this three year fuel oil expense from the nuclear plant economics improves its net present value as shown when comparing Figures $1-3$ and $1-5$.

Capital cost estimates are of a quality consistent with the scope of this feasibility study; i.e., they are budgetary in nature. The estimates represent neither the maximum nor minimum costs, but rather represent average costs to be expected for the systems under study. Capital investment costs for each study plant are summarized in Tables $1-1$ and 1-2. Refer to section 1.4 .1 and 1.4 .2 for plant descriptions.

The optimum nuclear plant configuration within the constraint of Dupont steam requirements, is one which delivers a maximum of 1,000,000 lb/hr process steam flow at $550 \mathrm{psig}$ and $7500 \mathrm{~F}$, while generating an average of 26.1 MW net electrical power via a condensing-cycle turbinegenerator in the PE-CNSG secondary steam loop. This is identified as Nuclear Case 5 in the body of the report. For this study, it is considered to be "Nth-of-a-Kind" and exclusive of "First-of-a-Kind" costs.

For both assumptions for construction start date, the optimum coal plant configuration is one which delivers a maximum of 1,000,000 1b/hr process steam at $550 \mathrm{psig}$ and $7500 \mathrm{~F}$ while generating an average 36.1 MW net electrical power via an extraction-condensing turbine generator. Boiler design steam conditions are 1500 psig at $950 \% \mathrm{~F}$. This plant is Coal

Case 7 .

The results for these two plants are shown in Figures $1-3$ through $1-6$ for both the concurrent nuclear/coal plant construction start date and the concurrent nuclear/coal plant operation start date. 


\subsubsection{Economic Zeasibility - (Continued)}

The nuclear plan= is presented for both reprocessing and non-reprocessing fuel cycles, while the coal plant is presented as a high-sulfur coal plant with flue gas scrubbing for 1978 delivered coal prices of $\$ 1.20, \$ 1.40$ and $\$ 1.60 / 10^{6}$ Btu.

Under the assumptions in force for this study, the coal plant is seen to be the economic choice for 1978 coal prices up to approximately $\$ 2.10-\$ 2.20 / 106 \mathrm{Btu}$ for concurrent nuclear/coal plant construction start diate and up to $\$ 2.40-\$ 2.50 / 106 \mathrm{Btu}$ for concurrent nuclear/coal plant operation start date.

-

Since these 1978 coal prices are quite high and not to be realistically expected, the coal plant is the economic choice of this study. It is judged to be possible to obtain $\$ 1.20 / 10^{6} \mathrm{Btu}$ high-sulfur coal and the $\$ 1.40-\$ 1.60 \mathrm{high}$ sulfur coal price is quite likely obtainable on long term contract.

The PE-CNSG plants are much more capital-intensive projects than the coal-fired plants. Even though the PE-CNSG annual operating costs are substantially lower than annual costs for coal plants, the large capital investment required for the PE-CNSG results in low NPV's that are not competitive with the coal-fired option. studied.

For comparison purposes, Figures $1-4$ and $1-6$ also show the fuel cost of process steam derived from number 6 fuel oil. This comparison is idealized in that it assumes that all capital related costs have ceased and that operating and maintenance costs are zero. For the idealized conditions just cited, oil may be an attractive alternative to either coal or nuclear systems.

The relatively high energy costs predicted for nuclear (compared to earlier estimates) arise from several factors. The average industrial steam load of $723,000 \mathrm{lb} / \mathrm{hr}$. amounts to only $56 \%$ of rated reactor capacity, and while the excess steaming capacity is used to generate electricity, power generation does not provide sufficient net revenue to yield attractive overall steam production costs. For a PE-CNSG producing steam only, a rise in industrial steam load from 56\% to $100 \%$ of reactor capacity would lower steam cost by about $20 \%$.

The requirement for superheated steam imposes an additional cost penalty on the PE-CNSG since a supplemental oil fired superheater is required to elevate the reactor steam to about $750^{\circ} \mathrm{F}$. Thus, oil provides about one-fifth of the energy consumed to produce process steam during normal operations. Superheating increases steam costs by about $10 \%$.

A PE-CNSG application for supplying base-load saturated steam to industry, either prime steam or via cogeneration, probably would be more attractive. 


\subsubsection{Economic Feasibility - (Continued)}

Present results project saturated steam costs of about $\$ 2 / 10^{6} \mathrm{Btu}$ in 1978 dollars for a $1,288,000 \mathrm{lb} / \mathrm{hr}$ constant steam demand and a $15 \%$ discount rate. Oil based superheat would increase the steam cost to about $\$ 2.20 / 106 \mathrm{Btu}$; this is roughly equal to the cost of superheated process steam from a Case 7 coal based plant with a 0.85 plant availability factor and burning high sulfur coal costing $\$ 1.70 / 106$ Btu or $\$ 37 /$ ton.

\subsubsection{Technical Feasibility}

A11 PE-CNSG and coal-fired process steam generation systems studied are technically feasible. Both types of systems represent essentially state-of-the-art technology. An application of the PE-CNSG would be a First-of-a-Kind (FOAK) installation and as such the Nuclear Regulatory Commission (NRC) would have to be satisfied concerning the PE-CNSG safety features. There is no reason to anticipate that the PE-CNSG would prove technically unsatisfactory to the NRC in light of both its small size and its application of essentially state-of-the-art technology. Considerable preparation for soliciting NRC approval has already been factored into the PE-CNSG design.

The coal plant poses no apparent problems from a technical licensing standpoint. However there is a degree of uncertainty about future environmental requirements. Based on current environmental regulations, the coal plant design studied are acceptable in the Victoria, Texas area if the flue-gas is scrubbed.

\section{3 study scope}

This feasibility study has been designed specifically around the requirements of the Du Pont plant site at Victoria, Texas. The study includes site, technical, and economic comparisons between B\&W's PE-CNSG and coal-fired facilities for the generation of up to $1,000,0001 \mathrm{~b} / \mathrm{hr}$. of process steam at $550 \mathrm{psig}$ and $750^{\circ} \mathrm{F}$. Several alternatives of each concept (nuclear/coal) have been investigated, some of which include cogeneration of electrical power. PE-CNSG and coal cycles have been individually developed to make best use of the potentials inherent in each, subject to the conditions required by the Du Pont plant site application. The most economically attractive nuclear and coal options are compared in detail.

In order to insure that this study is compatible with the specific plant site, Du Pont has supplied certain site, technical, and economic information. This information includes site layout anc topography, suggested study sites, soil and subsoil data, and economic inputs including state and local tax rates, insurance rates, labor rates, and backup steam supply costs. Information not supplied by Du PCnt has been estimated. All of the above parameters are documented in the body of the report. 


\subsection{Study Scope - (Continued)}

Significant study premises are itemized below:

(1) Du Pont supplies, at their existing header; deaerated and treated boiler feedwater (including makeup) in sufficient quantities for each study plant. The feedwater is supplied at $50 \mathrm{psig}$ and $280^{\circ} \mathrm{F}$.

(2) Du pont receives, at their existing header, 550 psig, $7500 \mathrm{~F}$. steam from the study plants. Two of the five nuclear study plants supply saturated steam to the process. These plants were studied to gain insight into the effects of superheating with fuel oil and of operating the PE-CNSG at reduced load.

(3) Study plants having different availabilities, capacities or operating life are equalized economically by charging the study plant with the number 6 fuel oil equivalent of any. steam deficit with reference to the steam flow requirement. In so doing, each plant is compared on the basis of equal total $B$ tu production over the life of the project.

(4) Study plants having power generating capability are charged a utility backup fee for capability in excess of 15 MWe. Auxiliary power and/or net power generated by study plants is routed through Du Pont's existing substation, PPS-3.

(5) Service water, potable water, and fire water are provided by Du Pont at existing headers.

(6) Estimates include provisions for absorbing additional heat rejection loads resulting from the operation of the study plants.

(7) The study plants include provisions for all other items necessary for engineering, construction and operation. The cost of Du Pont internal administration and management has not been estimated.

This feasibility study compares the PE-CNSG with coal-fired alternatives. No attempt has been made to compare these systems with those facilities currently being cperated by Du. Pont.

\subsection{System Desicns}

\subsubsection{Nuclear Systems}

The PE-CNSG is an integral pressurized water reactor (PWR) pressurized by an electrically heated, external pressurizer. The reactor pumps are of the wet-motor type with impeller located within the reactor vessel. The steam generator consists of 12 modular, once-through units 


\subsubsection{Nuclear Systems - (Continued)}

located above the top level of the core in the annulus between the core and pressure vessel. See Figure 1-7. Steam from the steam generators is delivered to reboilers where tertiary (process) steam is generated. This process steam is then delivered either directly to process or to a fired superheater as required. Electrical power can be generated in the secondary steam loop if total secondary steam is not required for process steam generation.

See Figure 1-8 for the PE-CNSG containment arrangement and Table 1-3 for reactor coolant system design parameters. Reference 1 gives a complete description of the basic PE-CNSG system, and section 3. of this report summarizes the design features particular to this study.

Five configurations of this standard PE-CNSG were designed and studied. Reboiler, superheater, fuel cycle and electrical generation designs have been varied. See Figure $1-9$ for the simplified diagram of the cases. The following design points were considered:

Case $1-810,000 \mathrm{lb} / \mathrm{hr}$ maximum $(649,000 \mathrm{lb} / \mathrm{hr}$ average) process steam at $550 \mathrm{psig}, 750 \mathrm{~F}$. Du Pont to supply steam in excess of $810,000 \mathrm{lb} / \mathrm{hr}$. No electrical generation. Plant Factor, 0.41 Fig. 3-6

Case 2 - I,000,000 1b/hr maximum $(723,000 \mathrm{lb} / \mathrm{hr}$ average) process steam at $550 \mathrm{psig}, 750^{\circ} \mathrm{F}$. No electrical generation. Plant Factor, 0.45 - Fig. 3-7

Case $3-810,000 \mathrm{lb} / \mathrm{hr}$ maximum $(649,000 \mathrm{lb} / \mathrm{hr}$ average) process steam at $550 \mathrm{psig}$, saturated. No electrical generation. Plant Factor, 0.41 - Fig. 3-8

Case $4-1,288,000 \mathrm{lb} / \mathrm{hr}$ process steam flow (maximum that the CNSG with reboilers will deliver) at 550 psig, saturated. No electrical generation. Plant Factor, 0.80. - Fig. 3-9.

Case 5 - 1,000,000 $1 \mathrm{~b} / \mathrm{hr}$ maximum $(723,000 \mathrm{lb} / \mathrm{hr}$ average) process steam flow at $550 \mathrm{psig}, 7500 \mathrm{~F}$ with provisions for generating condensing cycle electrical power with reactor secondary steam when system is delivering less than design steam flow to process. Plant Factor, 0.80 - Fig. 3-10.

Plant Factor is-defined as annual energy output divided by maximum possible annual energy output assuming continuous, full load reactor operation. 


\section{4.2 Coal Systems}

Four coal-fueled boiler cycles were studied and each cycle was developed to fire either high-sulfur Illinois coal $(10,900 \mathrm{Btu} / 1 \mathrm{~b})$ with flue gas scrubbing or lcw-sulfur Wyoming coal $(8,250 \mathrm{Btu} / \mathrm{lb})$ without flue gas scrubbing, for a total of eight coal plant designs. See Figure 1-10 for a typical schematic arrangement of a high-sulfur coal-fired steam generator system. Each of the coal plant designs satisfies the 1,000,000 1b/hr peak process steam flow requirement. Electrical cogeneration was investigated tc more fully utilize the potential of the coal plant concept. The following cases were considered:

Case $1-1,000,000 \mathrm{lb} / \mathrm{hr}$ maximum $(723,000 \mathrm{lb} / \mathrm{hr}$ average) process steam flow at $550 \mathrm{psig}, 750^{\circ} \mathrm{F}$. No electrical generation. Boiler designed at 580 psig, 7500F. Illinois Coal. Plant Factor, 0.67

Case 2 - Same as 1 except Wyoming coal.

Case $3-1,000,0001 \mathrm{~b} / \mathrm{hr}$ maximum $(723,0001 \mathrm{~b} / \mathrm{hr}$ average) process steam flow at 550 psig, $750^{\circ} \mathrm{F}$ with steam flow not required for process directed through a condensing cycle turbine-generator. Boiler designed at $580 \mathrm{psig}, 750^{\circ} \mathrm{F}$. Illinois coal. Plant Factor, 0.92 .

Case 4 - Same as 3 except Wyoming Coal.

Case 5 - 1,000,000 1b/hr maximum $(723,0001 \mathrm{~b} / \mathrm{hr}$ average) process steam flow cenerated at $1,500 \mathrm{psig}, 950^{\circ} \mathrm{F}$, and delivered to process. at $550 \mathrm{psig}, 750^{\circ} \mathrm{F}$ through a back pressure turbine-generator. Illincis coal. Plant Factor, 0.67 .

Case 6 - Same as 5 except wyoming Coal.

Case 7 - 1,000,000 1b/hr maximum $(723,0001 \mathrm{~b} / \mathrm{hr}$ average) process steam flow generated at 1,500 psig, $950 \circ \mathrm{F}$ and delivered to process through an extraction-condensing turbine-generator at 550 psig, 750\%F. Illinois Coal. Plant Factor, 0.92 .

Case 8 - Same as 7 except Wyoming Coal.

Plant Factor is defined in Section 1.4.1.

\subsection{Summary of Recommendations}

The economic analyses have shown that on an all-equity, NPV basis, the nuclear plants are not competitive economically with coal fired plants for this specific application under the present ground rules. A. number of constraints particular to this application have been identified which seems to place an economic penalty on the nuclear option. The following recommendations, if pursued, might determine if removal of the constraints would bring about a significant improvement in the relative ranking of small industrial reactors. 


\subsection{Summary of Recommendations - (Continued)}

(1) Consider debt financing in cash flow analyses. This is necessary due to the wide differences in capital investment required between the nuclear and coal plants.

(2) Study the economics of converting existing plants to accept saturated steam. This improves the economcis of the CNSG plant considerably, especially as the steam demand increases towards the CNSG generating capacity.

(3) If use of saturated steam is not feasible, consider alternative fuels for superheating, including waste or by-product fuels. Since Du Pont is currently firing their waste fuels to produce steam, this recommendation does not apply to them. It is stated here as a recommendation for similar applications where waste or by-product fuel sources exist but are not being used to generate steam. 
A

B

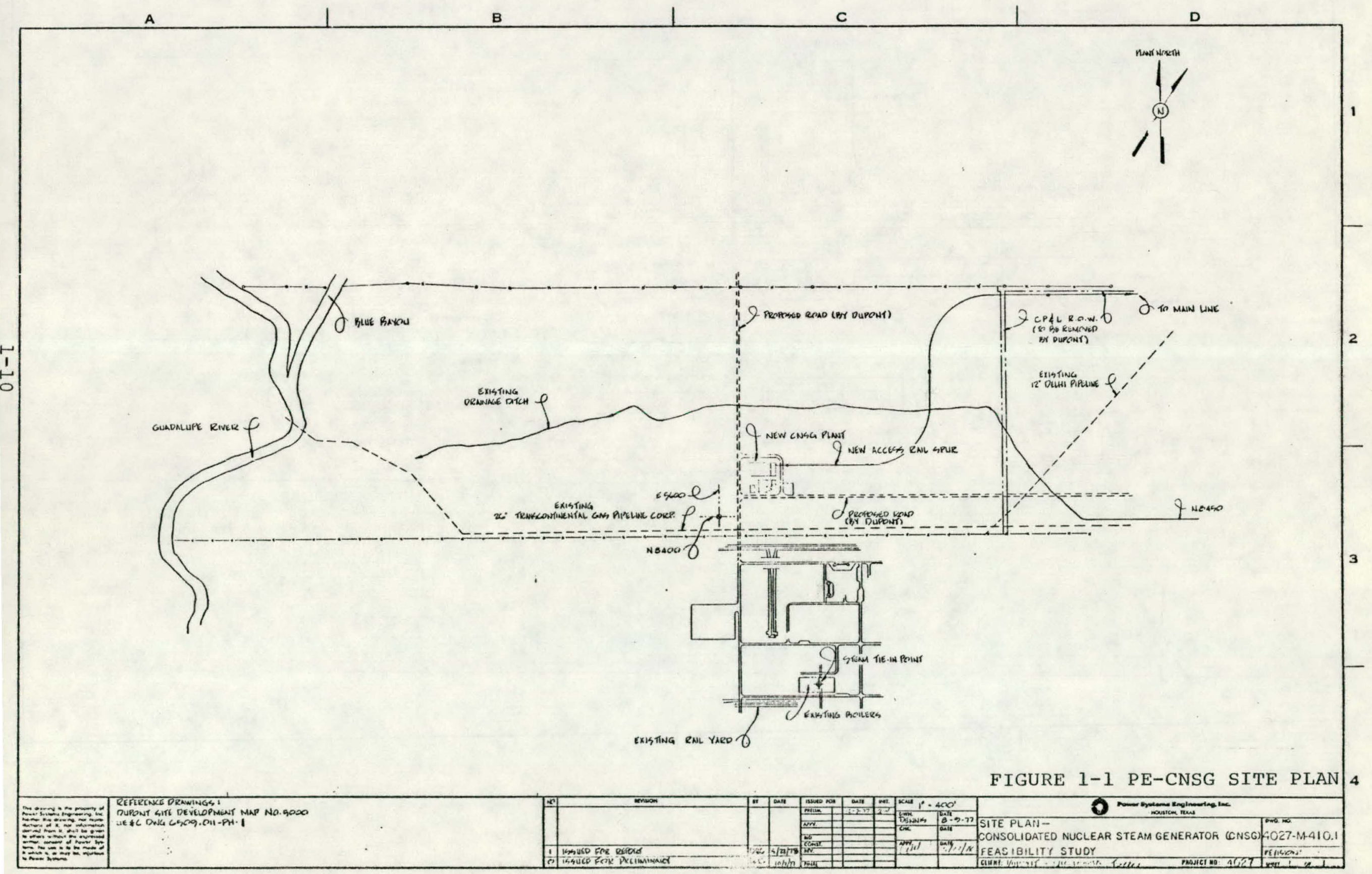


A

B

c
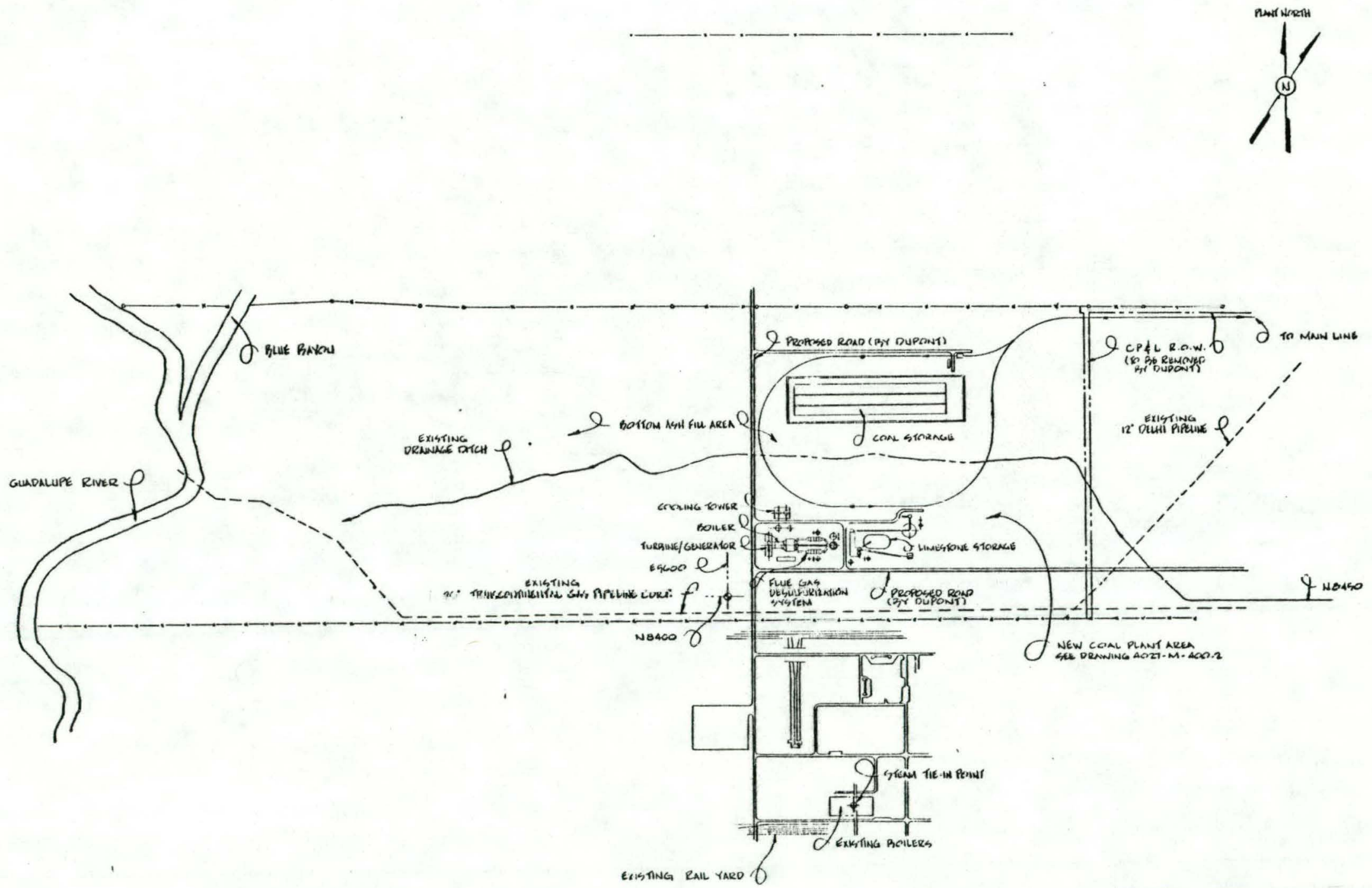

FIGURE 1-2 COAL PLANT SITE PLAN 


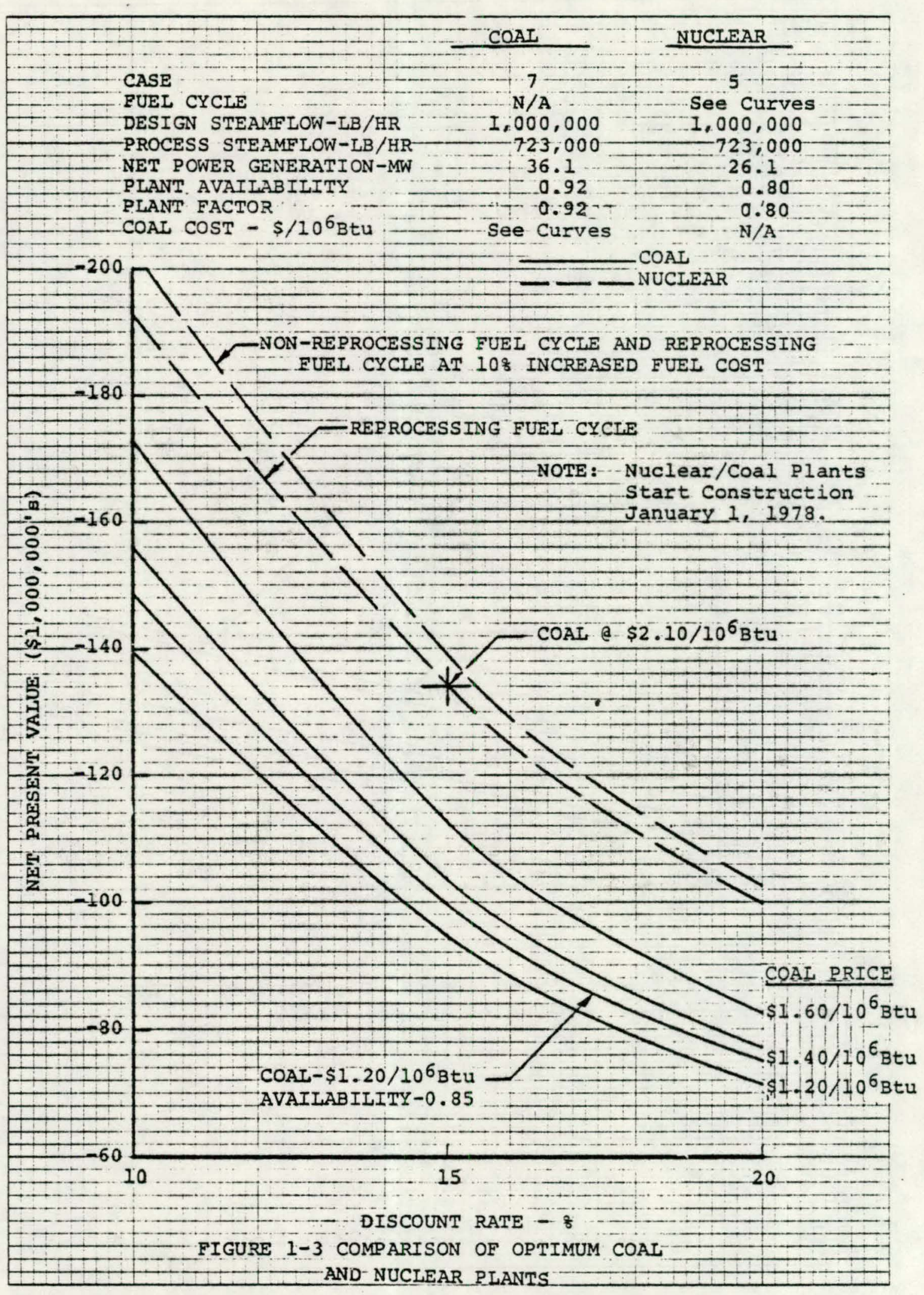

$1-12$ 


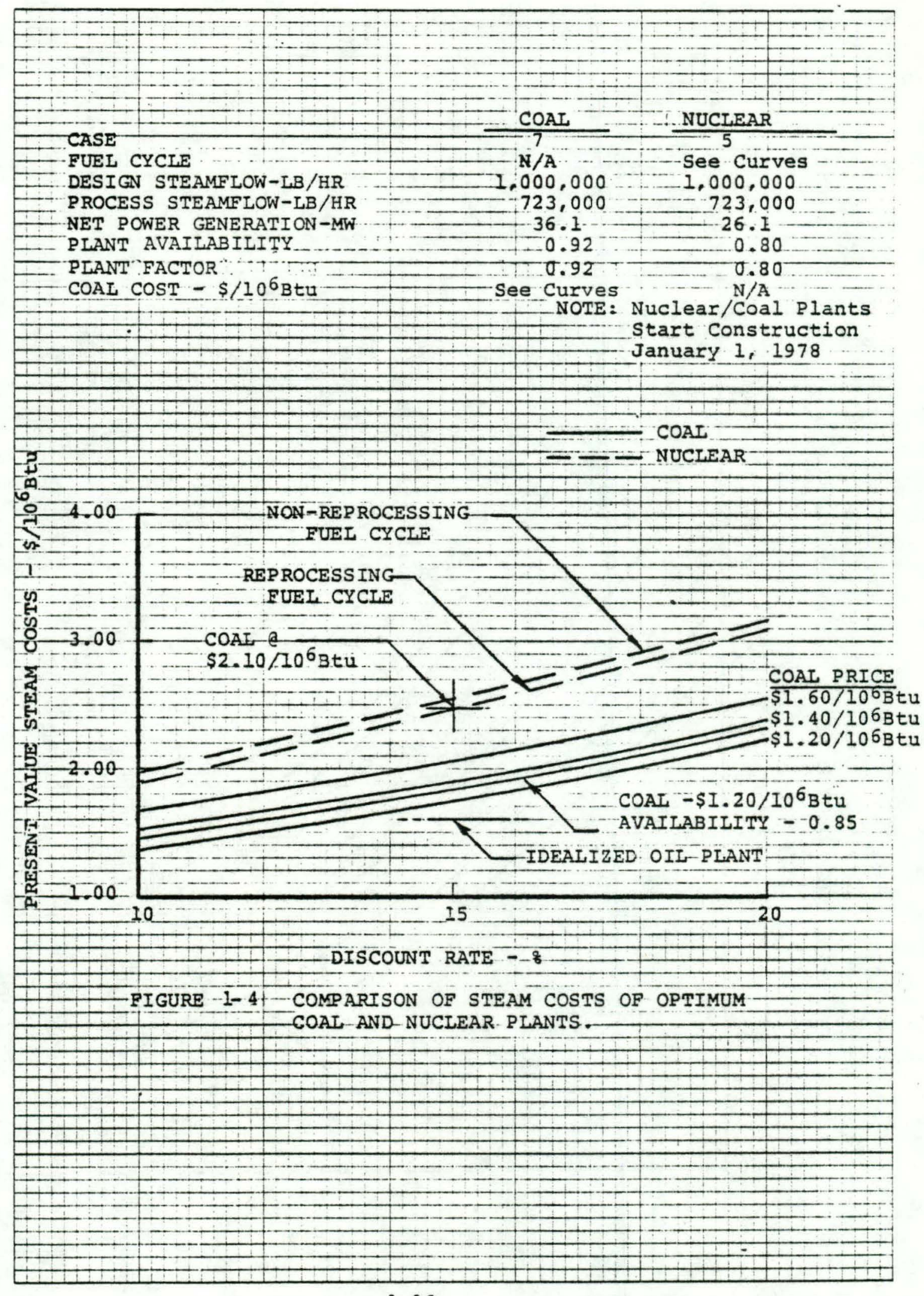

1-13 


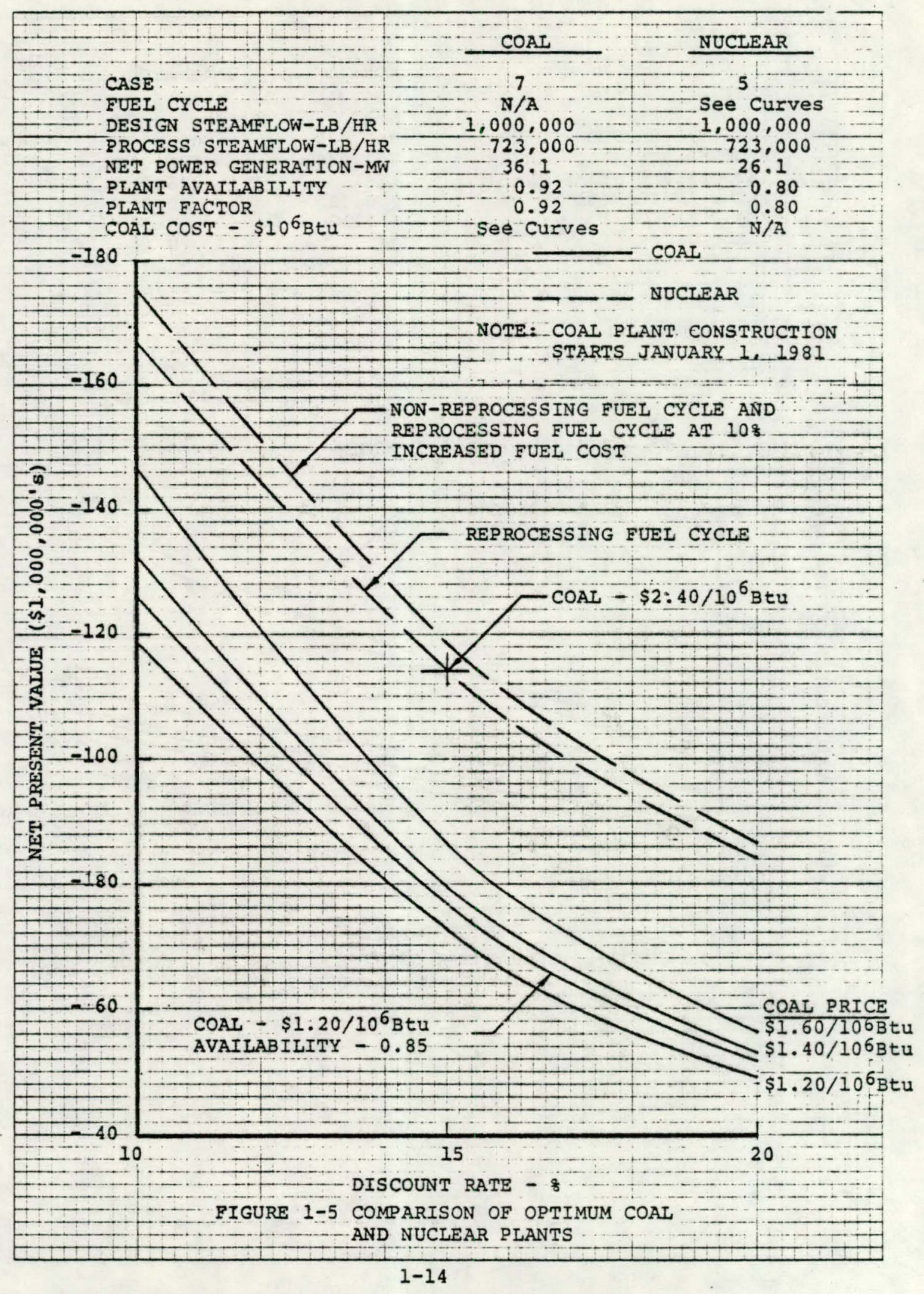




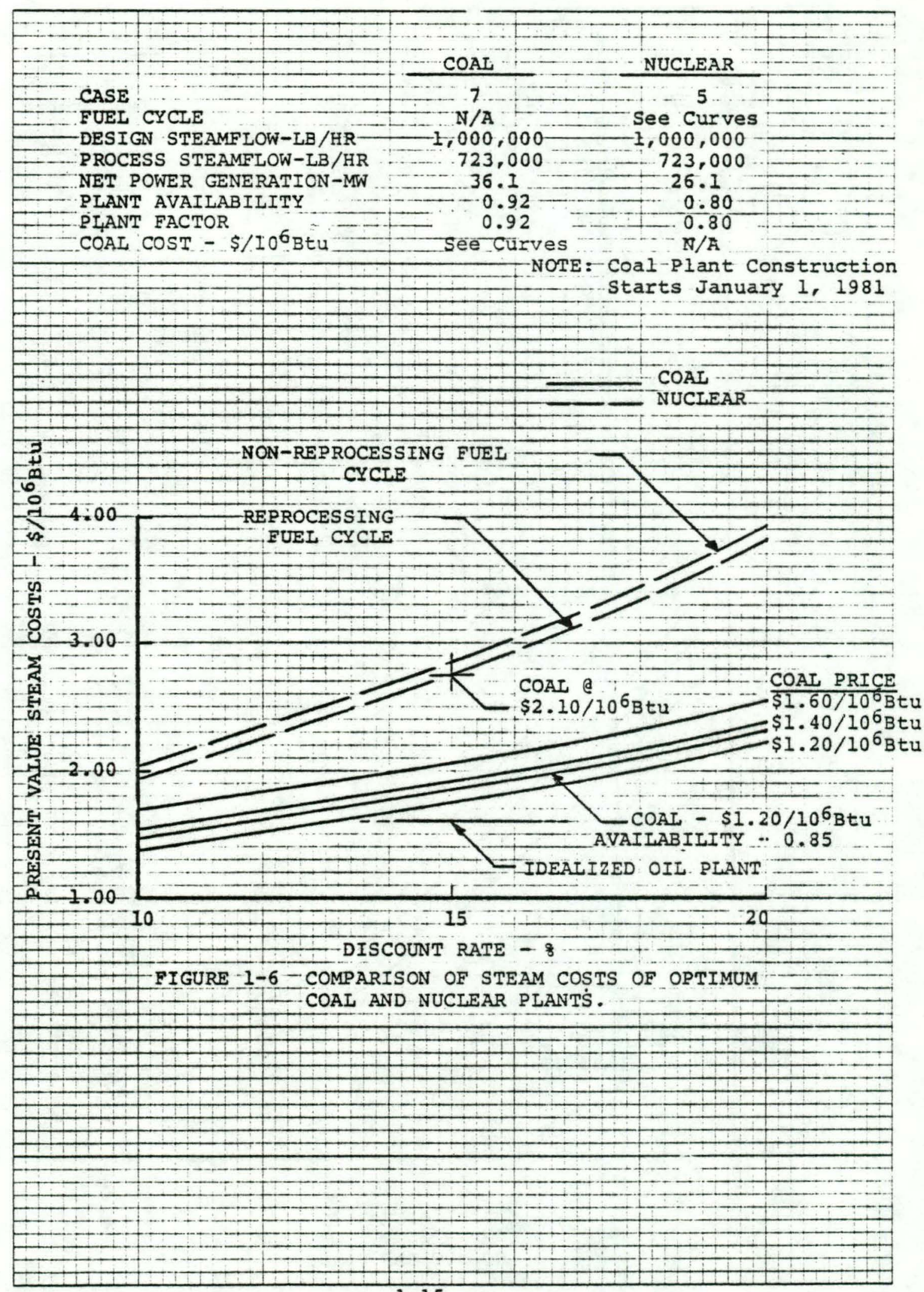

$1-15$ 
Figure 1-7 PE-CNSG Reactor Vessel

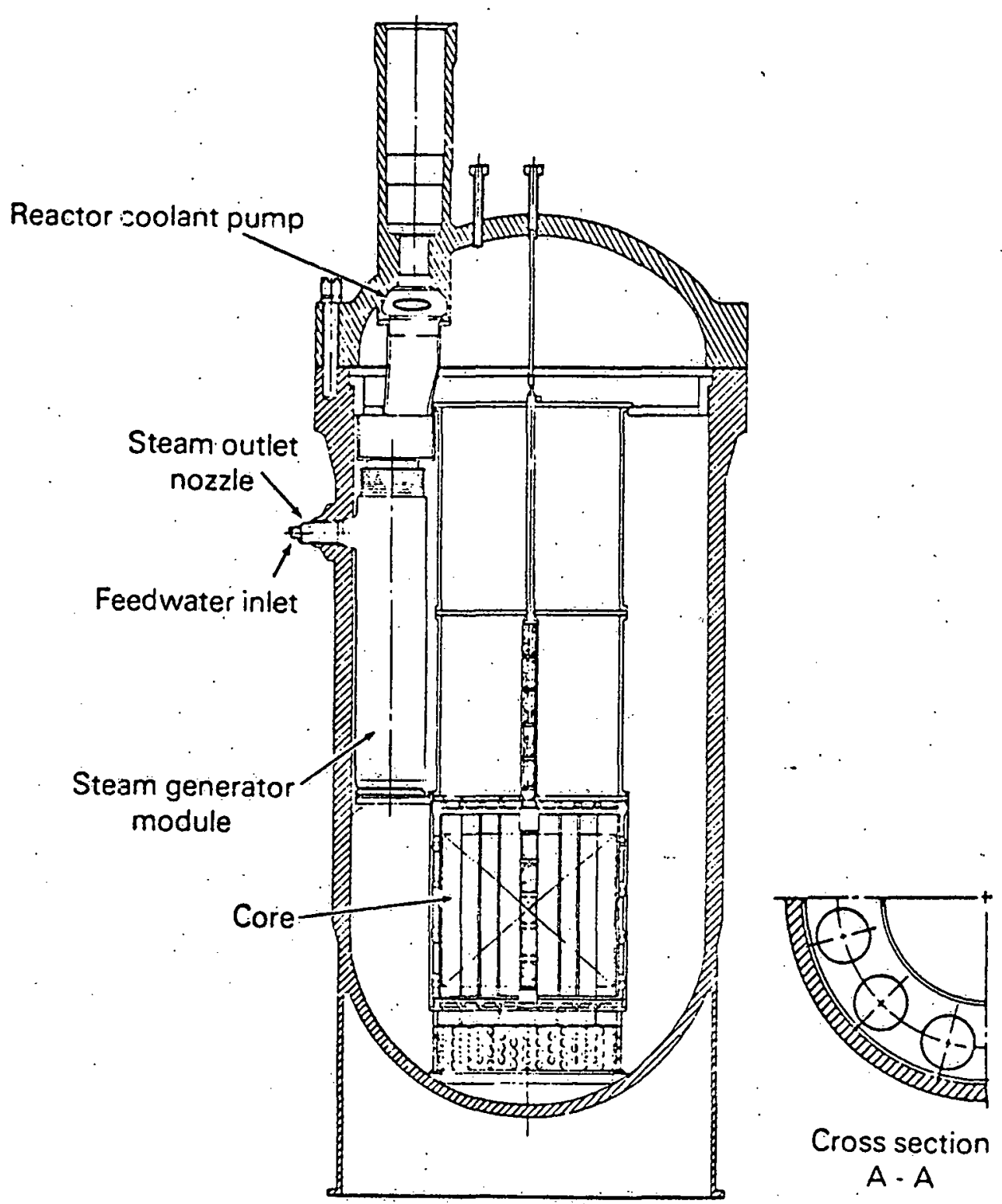


FIGURE $\quad 1-8$

355 MiNt PE-CNSG CONTAINMENT afRANGEMENT

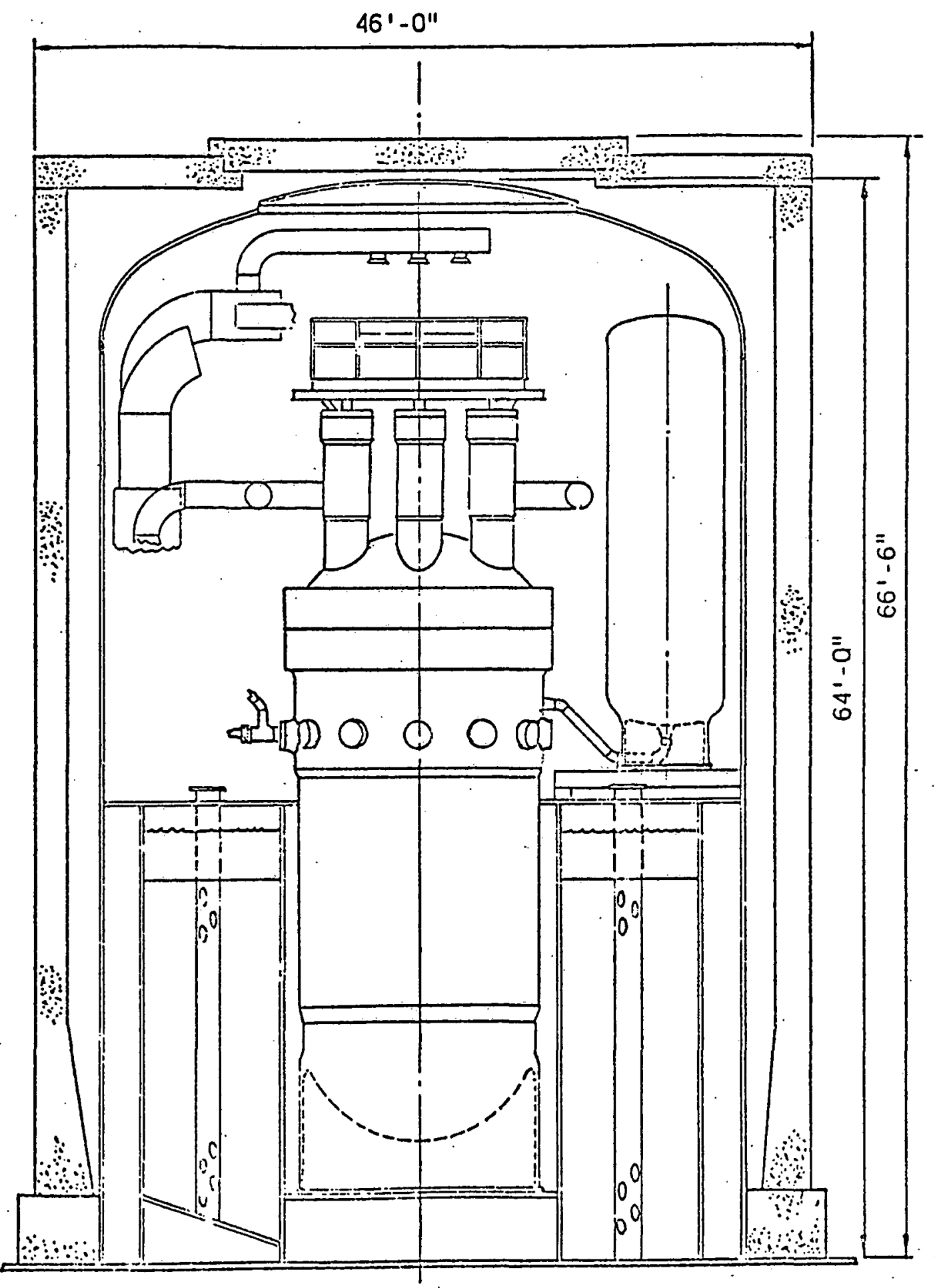


FIGURE 1-9

DUPONT STUOY CASES
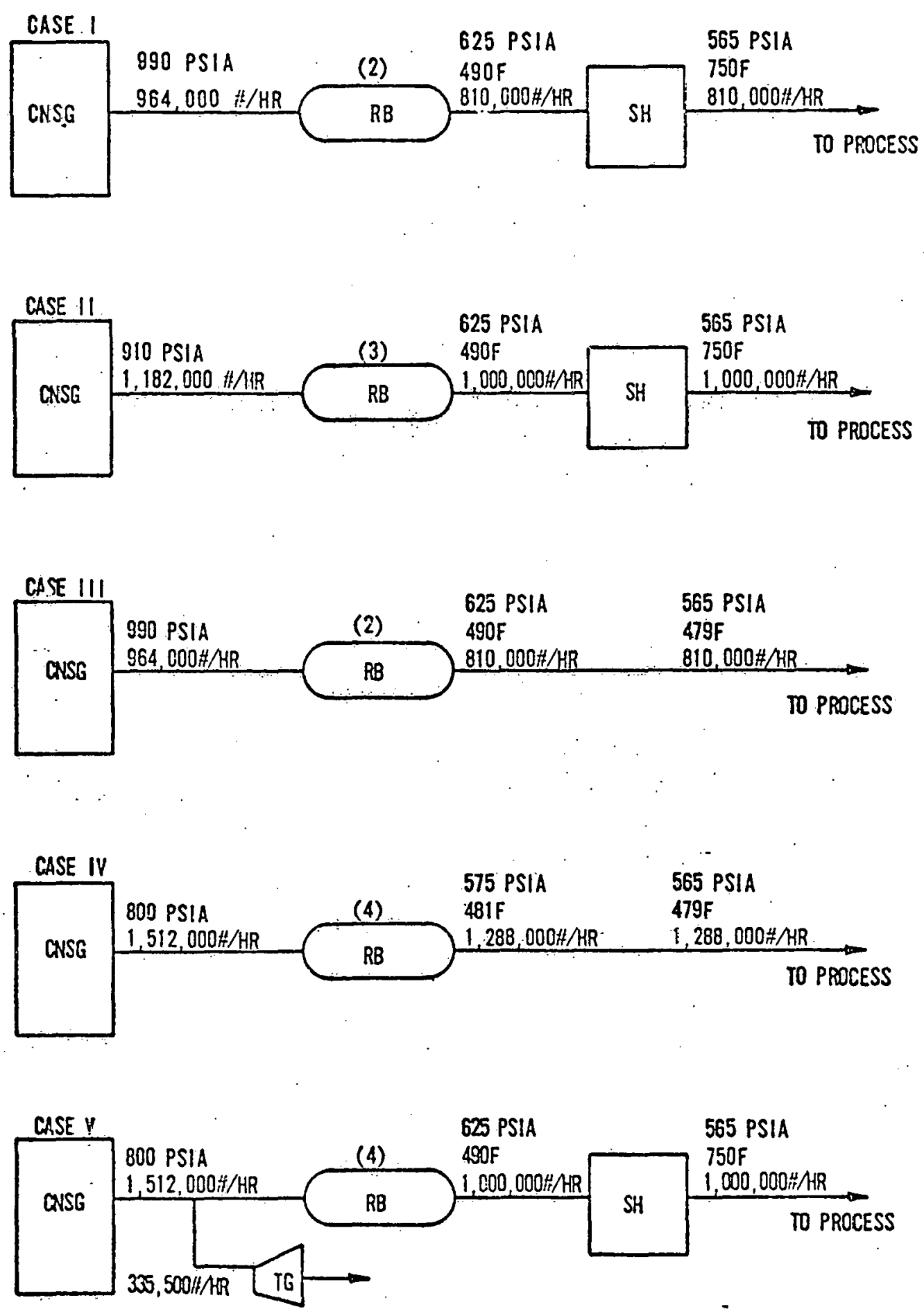


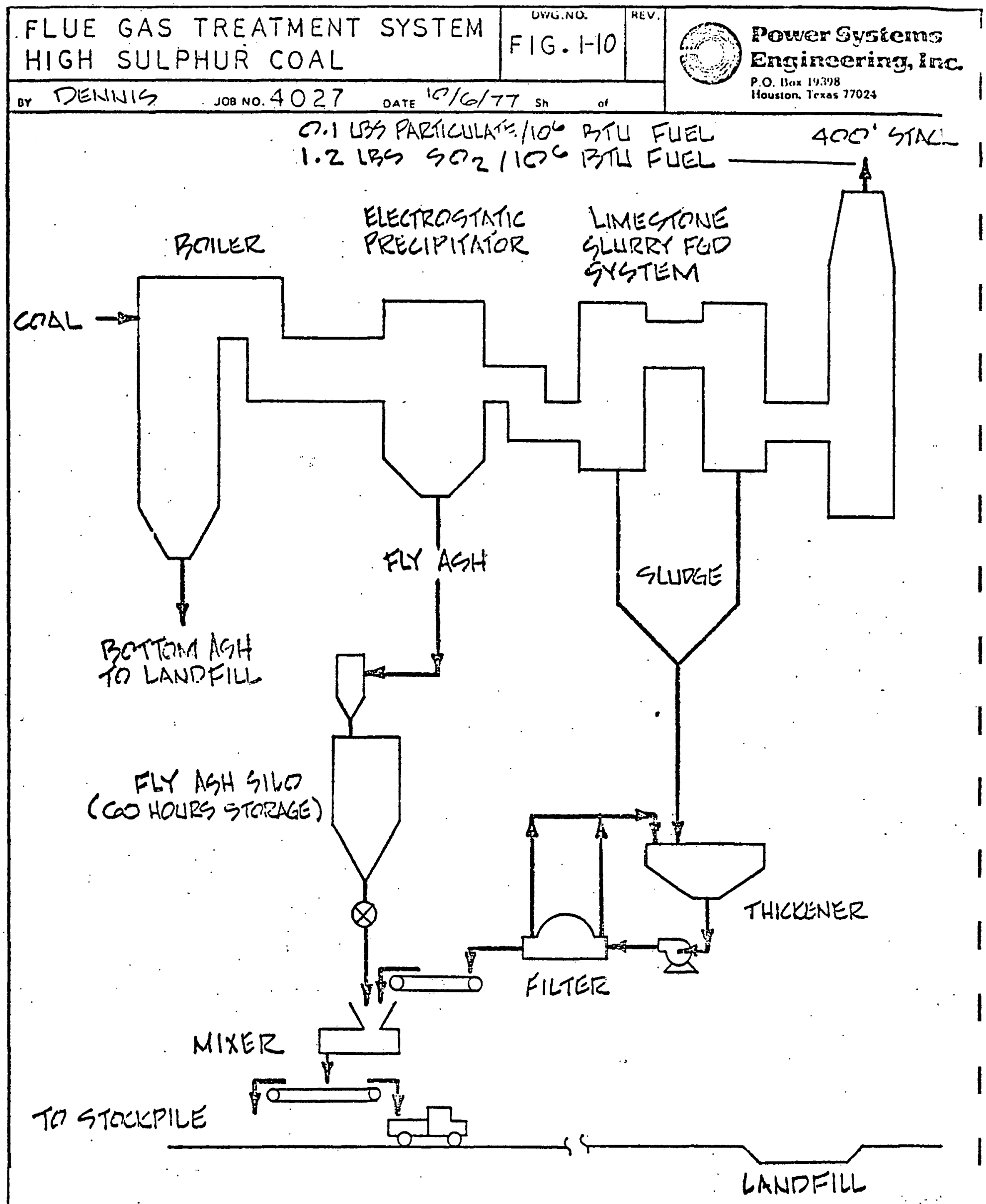


TABLB 1-1

PE-CNSG CAPITAL COST ESTIMATES

(\$1,000' - AASE JANUARY 1, 2978)

\begin{tabular}{|c|c|c|c|c|c|c|}
\hline \multirow{2}{*}{\multicolumn{2}{|c|}{$\cdots$}} & \multicolumn{5}{|c|}{ CA $A$ B } \\
\hline & & 1 & 2 & 3 & . & 5 \\
\hline $\begin{array}{l}\text { PROCESS STRAM } \\
\text { DESIGM CONDITION.' }\end{array}$ & 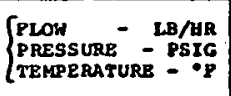 & $\begin{array}{r}010,000 \\
550 \\
750\end{array}$ & $\begin{array}{r}1,000,000 \\
550 \\
750\end{array}$ & $\begin{array}{r}810,000 \\
550 \\
4740\end{array}$ & $\begin{array}{r}1,288,000 \\
550 \\
678 .\end{array}$ & $\begin{array}{r}1,000,000 \\
550 \\
750\end{array}$ \\
\hline DESIGA PONER GEARRU & TTION (GROSS) & 0 & 0 & 0 & 0 & 34 \\
\hline
\end{tabular}

\begin{tabular}{|c|c|c|c|c|c|c|c|c|c|c|c|c|c|c|c|}
\hline & \multicolumn{15}{|c|}{ BSTIMATES } \\
\hline & CASG & \begin{tabular}{|l|} 
SUPER- \\
HEATER \\
PRRCESS \\
INTER- \\
FACING \\
\end{tabular} & SOTALS & CNSG & \begin{tabular}{|l} 
SUPER- \\
HPATER \\
QRROCESS \\
INAER- \\
PACING \\
\end{tabular} & $\begin{array}{l}\text { SU⿴囗 } \\
\text { TOTALS }\end{array}$ & CNSG & \begin{tabular}{|l|} 
SUPER- \\
HEATER \\
PROCESS \\
INTER- \\
PACING \\
\end{tabular} & $\begin{array}{l}\text { SUB- } \\
\text { TOTALS }\end{array}$ & CNSG & $\begin{array}{l}\text { SUPER } \\
\text { HEATER } \\
\text { PROCESS } \\
\text { INTER- } \\
\text { FACING } \\
\end{array}$ & SUB- & CNSG & \begin{tabular}{|l|} 
SUPER \\
HEATER \\
PROCESS \\
INTER- \\
FACING \\
\end{tabular} & $\begin{array}{c}\text { SUB- } \\
\text { TOTALS }\end{array}$ \\
\hline LAND & 96 & --- & 96 & 96. & $\cdots$ & 96 & 96 & --.- & 96 & 96 & --- & 96 & 96 & --- & 96 \\
\hline STAUCTURES AND IMPROVEMEHTS & 23,921 & 684 & 24.605 & 23,972 & .684 & .24 .656 & 23,921 & 634 & 24,555 & 24.022 & 634 & 24.636 & 24,261 & & 25,127 \\
\hline REACTOR PLANT & 58,682 & $-\cdots$ & 58.682 & 58,682 & $\therefore-$ & 58,682 & 58,682 & --- & 58,682 & 58,682 & --- & 58,682 & 58,682 & --- & 58.682 \\
\hline TURaINE PLANT & $\cdots$ & --- & $-\cdot$ & -- & $\cdots$ & $\cdots$ & -- & $\cdots$ & --- & -.- & --- & $\cdots$ & 6,346 &.- & 6,346 \\
\hline $\begin{array}{l}\text { SECONDARY/TERTIARY/SUPRRHEATER } \\
\text { SYSTEYS }\end{array}$ & 3,027 & 4,778 & 7,805 & 3.641 & 5,101 & 8,742 & 3,027 & 3,091 & 6,110 & 4,244 & 3,091 & 7,335 & 3,975 & 5,101 & 9.076 \\
\hline RLECTRICL PLANT & 7.166 & $\cdots$ & 7,466 & 1.166 & -- & 7,466 & 7,466 & $\cdots$ & 7,466 & 7.466 & $\cdots$ & $\cdot 7,166$ & 8,881 & 1,093 & 9.974 \\
\hline MISCELLANEOUS PLANT EQUTPRERT & 3.978 & $\cdots$ & 2,978 & 2,978 & -- & 2.978 & 2,978 & -- & $2 . \dot{9} 78$ & 2,978 & -- & 2,978 & 3,122 & $\cdots$ & $3,12:$ \\
\hline OTAER COSTS & 2,300 & -- & 2,200 & 2,200 & -- & 2,200 & 2,200 & --- & 2.200 & 2,200 & --- & 2,200 & 2,500 & -- & 2.506 \\
\hline UNDISTRIBUTED COSTS & 26,090 & $\underline{1,111}$ & 17.201 & 16,090 & $\underline{1,176}$ & 17,266 & 26,090 & 764 & 16,054 & $\underline{26,090}$ & 764 & $\underline{16.854}$ & $\underline{12,250}$ & 2,430 & $18,6 \mathrm{eg}$ \\
\hline SUBTOZNA & 124,160 & 6,573 & 121,033 & 115,125 & $6,96 \mathrm{i}$ & 122,086 & 111,160 & 4,489 & 128.949 & 215,758 & 4,489 & 120,247 & 125,116 & 0.487 & $133,60=$ \\
\hline 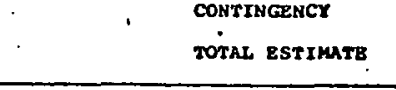 & 6,327 & 667 & $\frac{6,994}{129,027}$ & 6,414 & 205 & $\begin{array}{r}1,219 \\
129,205 \\
\end{array}$ & 6.327 & 4 & $\frac{6,785}{25,739}$ & 6,484 & 458 & $\begin{array}{r}6,942 \\
127,189 \\
\end{array}$ & 3.426 & 858 & $\begin{array}{r}8,204 \\
111,88 \\
\end{array}$ \\
\hline
\end{tabular}


TABLE 1-2

COAL PLANT CAPITAL COST ESTIMUTES

(\$1,000\% - BASE JNUUARY 1, 1978)

\begin{tabular}{|c|c|c|c|c|c|c|c|c|c|}
\hline & \multicolumn{8}{|c|}{ CABE } \\
\hline & & 1 & 2 & 3 & 1 & 5 & 6 & 7 & 8 \\
\hline $\begin{array}{l}\text { PROCESS STEAM } \\
\text { DESIAN CONDITIONS }\end{array}$ & 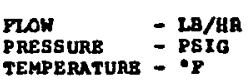 & $\begin{array}{r}1,000,000 \\
5500 \\
750\end{array}$ & $\begin{array}{r}1,000,000 \\
550 \\
750\end{array}$ & $\begin{array}{r}2,000,000 \\
550 \\
730\end{array}$ & $\begin{array}{r}1,000,000 \\
550 \\
550\end{array}$ & $\begin{array}{r}1,000,000 \\
550 \\
750\end{array}$ & $\begin{aligned} 1,000,000 \\
550 \\
750\end{aligned}$ & $\begin{array}{r}1,000,000 \\
550 \\
750\end{array}$ & $\begin{array}{rl}1,000 & 0000 \\
550 \\
750\end{array}$ \\
\hline $\begin{array}{l}\text { DESTGN POHRR GENERAT } \\
\text { TYPE OF COAL }\end{array}$ & ron $m$ (Gross) & HICH S̊ULPUR & LOY süpur & $\begin{array}{l}30,4 \\
\text { HIGH SULFUR }\end{array}$ & LOH SULPUR & $\begin{array}{l}25 \\
\text { HICH SULPUR }\end{array}$ & $\begin{array}{c}25 \\
\text { LOH SURFUR }\end{array}$ & $\begin{array}{l}51.5 \\
\text { HIGH SULFUR }\end{array}$ & $\begin{array}{c}51.5 \\
\text { LOW surfug }\end{array}$ \\
\hline
\end{tabular}

\begin{tabular}{|c|c|c|c|c|c|c|c|c|}
\hline & \multicolumn{8}{|c|}{ ESTSARES } \\
\hline LAND & $\$ \quad 100$ & $\$ \quad 100$ & 100 & 100 & $\$ \quad 100$ & 400 & 400 & \\
\hline SITEWORK & 1.125 & 1.125 & 1,125 & 1,125 & 1,125 & 1,125 & 1,225 & 1,125 \\
\hline BUILOINGS AND GTRUCTORES : & ie3 & 103 & 183 & 283 & 283 & 283 & 183 & 183 \\
\hline mar. yarn & 0.747 & 8,747 & 0,767 & $0 ; 941$ & 0.595 & 8.141 & 8,747 & $\dot{8}, 347$ \\
\hline GTCNA GEHERATOR & 19.050 & 15,560 & 15.650 & 15,560 & 27,500 & 16,150 & 17.500 & 16.450 \\
\hline TURAINE-GENERATOQ & --- & $-\cdots$ & 1,410 & 4,410 & 9,031 & 3,359 & 6.310 & 6,310 \\
\hline PROCESS MRCHANICAL EOUIPMERT & 4,584 & 5,057 & 5,534 & 6.000 & 4.731 & 5.231 & 5,664 & 6,074 \\
\hline ELECTRICAL & 3.088 & 3.115 & 4.460 & 4,457 & 4,236 & 4.233 & 4,866 & 4.863 \\
\hline CIVTL-STRUCTURAL & 732 & 500 & 921 & $m$ & 863 & 689 & 961 & 816 \\
\hline PROCESS PIPING AND INSTRURENTATIOA & 3,998 & 3,998 & 4,387 & 4,387 & 4.549 & 4.549 & 4,834 & 4,836 \\
\hline PLUR GAS DESULPURIZATION PACILITIES & 7.655 & $\cdots$ & 7,655 & ---- & 8.220 & $\cdots$ & 8,225 & ---- \\
\hline UNDYSTRYBUTED COSTS & $\cdot \underline{6,120}$ & $\underline{3,853}$ & 7,365 & $6,455^{\circ}$ & 7,418 & 6,339 & 2,359 & 7.164 \\
\hline SUBTOTAL & 52,282 & $\$ 42,626$ & 60,037 & $\$ 52,491$ & 61,103 & $\$ 51,305$ & $\$ 66.174$ & 57.266 \\
\hline CONTINGENCY & $5,228$. & $+4,264$ & 6,008 & $\underline{5,248}$ & $\underline{6,140}$ & 5,130 & 6,617 & $\underline{3,227}$ \\
\hline TOTAL ESTIMATE . & 857.510 & - 16.890 & 66,92 & 57.739 & 87,543 & 56,135 & $\$ 22,791$ & (62,993 \\
\hline
\end{tabular}


Table 1-3 Reactor Coolant System Parameters

NOMINAL VALUES

\begin{tabular}{|c|c|c|}
\hline Design Performance Summary & Metric & English \\
\hline Power & 365 MWt & 365 MWt \\
\hline Steam pressure at SG outlet (at full load) & $5.52 \mathrm{MPa}$ & 800 psia \\
\hline Steam temperature at SG outlet & $270^{\circ} \mathrm{C}$ & $518^{\circ} \mathrm{F}$ \\
\hline Steam flow & $191 \mathrm{~kg} / \mathrm{s}$ & $1.512 \times 10^{6}$ \\
\hline Feedwater inlet temperature & $204^{\circ} \mathrm{C}$ & $400 \circ \mathrm{F}$ \\
\hline Nominal core inlet temperature & $300^{\circ} \mathrm{C}$ & $571.6^{\circ} \mathrm{F}$ \\
\hline Nominal core outlet temperature & $319^{\circ} \mathrm{C}$ & $606.4^{\circ} \mathrm{F}$ \\
\hline Reactor vessel average temperature & $309.4^{\circ} \mathrm{C}$ & $589^{\circ} \mathrm{F}$ \\
\hline Rics flow & $3289 \mathrm{~kg} / \mathrm{s}$ & $26.06 \times 10^{6}$ \\
\hline Equipment Data/Design Performance Data & & \\
\hline No. of SG modules & 12 & 12 \\
\hline RCS total primary volume & $106.9 \mathrm{~m}^{3}$ & $3775 \mathrm{ft}^{3}$ \\
\hline Primary water volume & $99.8 \mathrm{~m}^{3}$ & $3525 \mathrm{ft}^{3}$ \\
\hline Pressurizer gas volume & $7.08 \mathrm{~m}^{3}$ & $250 \mathrm{ft} \mathrm{t}^{3}$ \\
\hline Reactor Vessel ID & $3.99 \mathrm{~m}$ & 157. in. \\
\hline No. of Control 3od Assemblies & 17 & 17 \\
\hline No. of fuel assemblies & 57 & 57 \\
\hline RC pump flow (four used) & $1.196 \mathrm{~m}^{3} / \mathrm{s}$ & $18,950 \mathrm{gpm}$ \\
\hline RC pump head & $32.31 \mathrm{~m}$ & $106 \mathrm{ft}$ \\
\hline RC pump expected power, hot & $0.326 \mathrm{MW}$ & $43.7 \mathrm{hp}$ \\
\hline $\begin{array}{l}\text { Pressurizer } \\
\text { Overall length } \\
\text { Sheel OD }\end{array}$ & $\begin{array}{l}8.969 \mathrm{~m} \\
2.013 \mathrm{~m}\end{array}$ & $\begin{array}{l}29 \mathrm{ft}, 5.125 \\
79.25 \text { in. }\end{array}$ \\
\hline
\end{tabular}




\subsection{INTRODUCTION}

To date, there have been no domestic applications of nuclear steam generation for industrial applications. Until the advent of the small PE-CNSG, nuclear plants had been much too large to consider for use by a single industrial user. Also, in the Gulf coast area, the incentive for industrial users to convert from inexpensive, plentiful, and clean natural gas fuel has been virtually nonexistent until the pencing fossil fuel shortage was recognized recently.

With the stated national goal of energy independence coupled with the domestic fuel oil and natural gas shortages and large oil import requirements at increasing and unpredictable cost, attention has been focused on increased utilization of abundant domestic fuels. The most abundant domestic fuel is coal, followed by nuclear fuel. Therefore, the current interest in energy production is now centered on the utilization of these two fuels. The Gulf coast is an area in which an industrial nuclear steam generation plant might prove economically attractive. Major coal deposits are located some distance from the Gulf Coast, and coal prices are expected to contribute to the nuclear plant appeal along the Gulf Coast more so than at other locations nearer coal supplies.

The B\&W PE-CNSG is a small nuclear reactor, being approximately onetenth the size and output of central generating station reactor plant. The 365-MW thermal capacity of the PE-CNSG is suited for applications requiring 1 to $1.2 \mathrm{milli}$ on $\mathrm{lb} / \mathrm{hr}$ of process steam. While the PE-CNSG is a pressurized water reactor (PWR) and designed to deliver saturated or slightly superheated steam, it is feasible to superheat this steam in an external fossil fired superheater with some economic penalty.

The technical and economic feasibility of using the PE-CNSG to provide process steam for industrial use has been found attractive for the hypothetical "Middletown, U.S.A." site in previous studies by ERDA, ORNL, $B \& W$, and $U E \& C$ (Reference 1). It is the intent of this study to determine PE-CNSG feasibility for an actual plantsite; namely, Du Pont śsité at Victoria, Texas.

The Du Pont site was chosen as a study site because it is within the range of $P E-C N S G$ applicability and is typical of large industrial steam users. In addition, Du Pont and other Texas industries are faced with cutbacks in their current natural gas supplies and increases in the price of natural gas. Therefore, if industry is to expand its operations, or even maintain current output, an alternative fuel is going to have to be utilized. Du Pont has already made provisions to burn number 6 fuel oil as a backup fuel, and the evaluation of coal as an alternative fuel has already been initiated by Du. Pont.

The study report herein has been designed to complement Du Pont's inhouse efforts to find economical alternative sources of energy for process steam production. Coal has been chosen for comparison with the nuclear option because Du jont' is also studying coal and because coal is the most plentiful domestic fuel and offers promise of being economically. attractive. 


\subsection{INTRODUCTION - (COntinued)}

The nuclear plants and coal plants considered in this study have been designed to match, in steam output and conditions, the following Du Pont requirements :

$\begin{array}{lr}\text { Steamflow: } & \\ \text { Peak } & 1,000,000 \mathrm{lb} / \mathrm{hr} \\ \text { Annual Average } & 723,000 \mathrm{Ib} / \mathrm{hr} \\ \text { Pressure } & 550 \mathrm{psig} \\ \text { Temperature } & 750 \mathrm{OF}\end{array}$

While a coal plant can be sized and optimized around the stated condiEiors, the PE-CISG capacity is fixed by design except for changes in operating mode and auxiliary equipment. The Du Pont requirements do not fully utilize the steaming capacity of the PE-CNSG, but the nuclear plarts studied have been optimized by including by-product electrical power to make more efficient use of the available steaming capacity.

The coal plants studied have been optimized as well through the incorporation of backpressure and/or extraction-condensing cycle electrical power generation.

This study has been a cooperative effort. Those participating in the stucy are the following:

Oak Ridge National Laboratory (ORNL)

Power Systems Engineering, Inc. (PSE)

The Babcock and Wilcox Company, Nuclear Power Generation Division ( $B \& W$ )

United Engineers and Constructors, Inc. (UE\&C)

E.I. Du Pont De Nemours and Company, Inc.. (Du Pont)

The study has been funded by the Department of Energy (DOE).

Du Pont provided all information necessary to interface this study with their requirements, and without Du Pont's significant contribution, this study would not have been possible.

The study was directed by ORNL with PSE acting as study coordinator. PSE was responsible for the physical interfacing of all study plants to the existing Du Pont system and for the development of all coal plant aspects of the study. The economic evaluation of alternatives was the responsibility of PSE as was the assembly of this final report. $B \& W$ and UE\&C were responsible for all aspects of nuclear study plant development, site evaluations and reporting. 


\subsection{SYSTEMS DESCRIPTIONS}

3.1 Design Reguirements

3.1.1 Description of Existing Plant

\subsubsection{General}

The site is large with adequate space for either the coal or nuclear alternative. Access to the site is by highway (Texas 185), daily rail (Southern Pacific and Missouri Pacific), and sea-level barge canal approximately 100 feet wide and 10 feet deep ( 8 feet deep into the plant). The Guadalupe river is adjacent to the barge canal. The site is at an average elevation of 65 feet MSL, or about 30 feet above the 100year flood level. The nearest residential population center to the plant is about 3 miles distant having a population of about 500 people. The city of Victoria is about 10 miles away and has a population of approximately 50,000. The principal use of land adjacent to Du Ponts property is for beef cattle grazing and farming. It is expected that the surrounding areas will tend towards industrialization in the future. Figure 3-1 locates the site.

Du Pont is a net purchaser of electrical power at the present time and the present electrical demand exceeds the generating capacity of all systems studied herein. Total steam production capability is $2.3 \mathrm{x}$ $10^{6} \mathrm{lb} / \mathrm{hr}$.

Cooling water and plant runoff are held in a pond for analysis and treatment prior to discharge into the river.

\subsubsection{Historical and Structural Geology}

The tertiary structures in the Gulf region, known as growth-faults, consist of a series of generally gulfward oriented faults in Louisiana and Texas initiated as a result of slumping, and often associated with salt or clay. The age of development and formation of the faulting is lower for faults nearer the Gulf. The oldest Pleistocene structures occur closest to the present shore and appear as large isolated salt deposits while the recent Pleistocene and salt structures are developing further south on what is known as the continental shelf. The sedimentation process presently is taking place in this area.

The thickness of the Quaternary strata reaches 12,000 feet of hard clays and silts (neritic deposits) which alternate with dune sands and hard clays and silts (shore deposits). Subsidence, consolidation, erosion and sedimentation as well as oxidation are some of the common features of this phase.

The structural geology of the Gulf Coastal plain is rather complex and started its development more than 230 million years before present (mybp) - The presence of salt and its movement during the Tertiary ( 65 to 2 mybp) have been responsible for the development of many types: of salt structures. This motion has been sustained by continued sedimentary loading in the Gulf. Also, a system of normal faults are known 


\subsubsection{Historical and Structural Geology - (Continued)}

to have developec in association with the development of salt domes.

In contrast to these, another system of structures known as growth faults exists in the Gulf Coastal Plain. These faults are most of the time dipping southward 40 to 60 degrees. This angle decreases as the fault extends downward, essentially becoming a bedding plain fault. The results therefore are essentially within the sedimentary. sequence and not an extention of the deeply buried tertiaric structures. The movement of these faults is contemporaneous and associated with sediment deposition. Since this is a rather slow phenomenon, it is believed that strain accumulation leading to sudden movement and generation oi seismic energy cannot take place.

\subsubsection{Site Geology}

A detailed geologic study on a rectangular area $5.4 \mathrm{x} 8.1$ miles with the Du Pont Victoria Plant at the center was prepared by Wm. H. Price. Co., Austin, Texas, with the purpose to determine the oakville-Catahoula strata injection capacity. The study shows that this is an area of massive sand development in the lower Miocene interval. It further indicates that the study area exhibits typical coastal geology with the sands dipping toward the coast and broken by down-to-the-coast faulting. Only minor faulting (less'than 200 feet throw) occur in the study area, although major faulting on the order of 1000 feet occurs several miles to the southwest and to the east of this region. It appears that a deep-seated salt intrusion occurs beneath the plant site area causing a local anticlinal structure which is fragmented by minor faulting.

The base of the Pleistocene (lissie) consists of fresh water sand which is the main aquifer $(300-350$ feet) from which sanitary water is obtained. The Pleistocene continues to the surface with marine clays of the outer coaster plain, known as Beaumont and having a thickness of about 500 feet. The Guadalupe River is the main supplier of water for the plant which requires about $30,000 \mathrm{gpm}$.

The soil reports made available by Du Pont show six borings labout 200 feet) which are located 1500 feet SE of the proposed PE-CNSG site. The boring supervision and testing of samples was performed by Trinity Testing Laboratories, Inc., Austin, Texas, who also prepared the foundation report. The results confirm a characteristic common to the Texas clays, the upper layer generating volume change problems, i. e., swelling or shrinkage depending on the conditions which are present. As the volume-change of these mostly bentonitic type clays affects mainly the surface layers, deep foundations are devoid of these problems if properly treated.

The borings have indicated the presence of expandable soils up to 16 feet from the surface. These consist of clay and sand clay with caliche and do normally require special treatment if foundations are placed on them. Below this depth normally follows silty sands and then sandy clay. These soils are cense or stiff and possess higher bearing values. 


\subsubsection{Site Geology - (Continued)}

Past experience with nuclear plants in the Gulf Coast area shows that plants located in similar soils and geologic conditions can be licensed.

\section{1 .2 steam and Power Requirements}

Du Pont currently operates two natural gas/haste-fuel-fired steam generation systems with number 6 oil backup:

(1) $650,0001 \mathrm{~b} / \mathrm{hr}, 550 \mathrm{psi} / \mathrm{saturated}$ steam directly to process. Steam is delivered to process at 550, 175, and 15 psi.

(2) $1,400,000 \mathrm{lb} / \mathrm{hr}, 550 \mathrm{psi} / 7500 \mathrm{~F}$. Normal generation is about $1,200,000 \mathrm{lb} / \mathrm{hr}$ annual average. In this system are numerous power turbines exhausting at 175 psi with exhaust steam being desuperheated and delivered to process. Total mechanical power generation from steam is approximately 20,000 horsepower.

The second system, (2), is the one which was "replaced" for the feasibility study. Since a certain amount of steam must be generated in this system out of the necessity to burn waste fuels, the levelized annual nuclear or coal steam generation delivered to the Du Pont system must be limited to $723,000 \mathrm{lb} / \mathrm{hr}$ at $550 \mathrm{psi} / 7500 \mathrm{~F}$. Sinse existing power turbines are to be maintained, the PE-CNSG/coal system interface is the existing 550 psi/7500F steam header.

Du Pont supplies deaerated feedwater with a conductivity of one micromho or better at approximately $50 \mathrm{psig}$ and $2800 \mathrm{~F}$. Therefore, the interface for feedwater is at Du Pont's feedwater header, with boiler feed pumps being the first major equipment in the study scope.

\subsubsection{Study Premises}

Significant study premises are itemized below:

(1) Du Pont supplies, at their existing feader, deaerated and treated boiler feedwater (including makeup) in sufficient quantities. for each study plant. The feedwater is supplied at $50 \mathrm{psig}$ and $280^{\circ} \mathrm{F}$.

(2) Du Pont receives, at their existing header, 550 psig, $7500 \mathrm{~F}$ steam from the study plants. Two of the five nuclear study plants supply saturated steam to the process. These plants were studied to gain insight into the effects of superheating with fuel oil and of operating the PE-CNSG at reduced load.

(3) ' Study plants having different availabilities, capacities, or operating life are equalized economically by charging the study plant with the number 6 fuel oil equivalent of any steam deficit with reference to the steam flow requirement. In so doing, each plant is compared on the basis of equal total Btu production over the life of the project. 
(4) Study plants having power generating capability are charged a utility backup fee for capability in excess of 15 MWe. Auxiliary power and/or net power generated by study plants is routed through Du Pont's existing substation, PPS -3 .

(5) Service water, potable water, and fire water are provided by Lu Pont at existing headers.

(6). Estimates include provisions for absorbing additional heat rejection loads resulting from the operation of the study plants.

(7) The study plants include provisions for all other items necessary for engineering, construction and operation. The cost of Du Pont internal administration and management has not been estimated.

This feasibility study compares the PE-CNSG with coal-fired alternatives. No attempt has been made to compare these systems with those facilities currently being operated by Du Pont.

\section{2 study systems}

3.2.1 Process Energy - Consolidated Nuclear Steam Generator Facility

\section{2 .1 .1 Plant Layout}

The plant layout and balance of plant (BOP) design for this study are based on a previous land-based PE-CNSG industrial application study conducted by $B \& W$ in conjunction with UE\&C. The objective of this study ias been to modify the previous study plant layout, conceptual design, and cost estimates to incorporate the site-specific and user-related ariteria of the existing Du Pont plant.

This section discusses the site laỹout and plot plan for the PE-CNSG for the Du Pont site. The major factors affecting the layouts are first discussed, followed by a description of the actual layout for the site.

As discussed in section 3.1.1.3, the site is characterized by soils which are prone to significant amounts of heave and settlement. Based upon these and other soil characteristics expected to be encountered at the site, a "floating foundation" concept was selected. This foundation concept consists of a thick concrete mat supporting one building (called "nuclear island") which houses all safety-related systems and which would further ensure evenly distributed loads on the foundation mat to minimize diferential settlements. Hanford Nuclear Plant (Units 3 and 4) for Washington Public Power Supply system is an example of a central station nuclear plant using the "floating foundation" concept because of soil conditions similar to those at the Du Pont site.

Soil conditions also have a major influence on the type of ultimate heat sink employed. A once-through intake and discharge system may be feasible for the site, but licensing probleims may arise because of soil conditions which are far from ideal (such as the plant founded on rock) for such a system. To avoid these potential problems a two-cell wet mechanical draft cooling tower with a basin for a 30 day supply of 


\subsubsection{Plant Layout - (Continued)}

makeup water is used. In any case, the difference in capital costs for the cooling tower and the once-through systems is believed to be small and cannot have a significant effect on the economic conclusions of this study.

Off-site power requirements of the nuclear plant were met by tapping the two independent $138 \mathrm{KV}$ lines which serve the existing plant. A transformer is used for each $138 \mathrm{KV}$ line to reduce the voltage to $4.16 \mathrm{KV}$. A circuit from each transformer is routed to the proposed PE-CNSG plant via an underground duct bank.

The site layout and plot plan based on these basic criteria were developed as shown in Figures $3-2$ and $3-3$ respectively. The particular location shown for the nuclear plant was selected for study purposes, and no attempt was made to determine if alternate locations may be more desirable based upon safety and/or economic considerations. The nuclear island, as discussed previously, contains the reactor service building which houses the reactor containment, the ultimate heat sink with the water reservior, the diesel generator, the fuel oil storage building and the control building. The borated and demineralized water. storage tanks are located on the roof of the reactor service building. The nuclear island proposed is considered to be a reasonable concept for the particular geological and soil conditions expected at the Du Pont site. The cost estimates assume that the reactor service, control diesel generator, and diesel fuel oil storage are contained in separate buildings, which is the basis for previous PE-CNSG studies. Specifically, it is assumed that the cost of the nuclear island is equal to a concept utilizing separate building. It is more than likely, however, that the nuclear island with a floating foundation will require additional strength in the mat, exterior walls, some interior walls, and the roof. While an evaluation of the additional cost is beyond the scope of this study, it is believed that the direct capital costs for the nuclear plant possibly may be higher by an amount up to $\$ 2,000,000$ for an installation using this concept. The cost estimates presented in section 4.0 do not reflect this potential additional cost.

The administration and process heat service buildings provide space for offices, change rooms, maintenance shop, spare parts storage, etc. The process area is an open area with ground floor slab and individual equipment foundations and supports. All facilities are located in two main sections that are joined by an underground piping tunnel which permits the installation of an access road through the middle of the plant layout. The access road permits easy movement of equipment and personnel around the site.

For the purposes of this study, it is assumed that the bottom of the foundation for the nuclear island is approximately 35 feet below existing grade. 


\subsubsection{Nuclear Steam Generating System}

The Consolidated Nuclear steam Generator (CNSG) concept was originally developed to provide propulsion power for commercial nuclear ships. This marine nuclear propulsion system, on which the PE-CNSG for industrial use is based, evolved as an advanced ship propulsion reactor having size, weight, and reactor safety benefits. The CNSG design was an extension and advancement of Babcock \& Wilcox's experience beginning in the late 1950 s with the company's activities in the NSS Savannah program. Design modifications to the basic concept have been made as a result of design reviews by both governmental and industrial groups. Modifications to the marine CNSG design were made only to change the design to landbased application where significant benefits could be realized.

\subsection{Reactor Coolant System}

The PE-CNSG is an integral pressurized water system in which the core, steam generator, and reactor pumps are located within the 157-inch inside diameter cylindrical reactor vessel (Figure.3-4). An electrically heated pressurizer of conventional design is connected externally to the pressure vessel to maintain the coolant in a sub-cooled liquid condition.

The steam generator consists of 12 modular once through units located above the top level of the core in the annulus between the core and. pressure vessel. A steam generator module can be isolated in the unlikely event of tube failure, with total steam output being reduced by only about $8 \%$. Each steam generator module incorporates counterflow heat transfer with shell-side boiling to produce saturated steam. The control scheme developed for this application maintains the reactor coolant average temperature constant at $589 \circ \mathrm{F}$ between $100 \%$ and $50 \%$ power and decreases the temperature linearly between $50 \%$ and $0 \% 10 a d$. The steam pressure varies from 800 psia at $100 \%$ power to 1100 psia at $50 \%$ power and remains constant at 1100 psia below $50 \%$ power.

Four primary coolant pump motors are mounted on the reactor vessel head with the shafts passing through the head to the impellers inside the vessel. The pumps are rated at $18,950 \mathrm{gpm}$ and $106 \mathrm{ft}$ head are vertical, single-stage, single-suction, constant-speed mixed-flow units. They are glandless, wet stator/rotor machines with no mechanical seal between the pump and motor. The pump motors are cooled by an external heat exchanger.

Tie reactor core consists of 57 fuel assemblies with $\mathrm{zircaloy-4}$ tubes containing slightly enriched $\mathrm{UO}_{2}$ pellets enclosed by welded end plugs. Tubes containing fuel are supported in assemblies by a spring-clip grid structure and end fittings. The 17 control rod assemblies, which control reactor power, are clusters of neutron absorber rods containing $\mathrm{B}_{4} \mathrm{C}$ that move in guide tubes within the fuel assemblies. 


\subsection{Reactor Coolant System - (Continued)}

During operation the reactor coolant is pumped downward through the steam generator tubes where the coolant transfers heat to the secondary side feedwater, thereby producing saturated steam. Leaving the steam generator modules, the coolant flows downward over mixing vanes and then turns upward into the core at the bottom of the reactor vessel. Heat generated by fission in the nuclear fuel raises the coolant temperature as it passes upward through the core. The coolant continues to flow upward until it reaches the reactor coolant pump suctions.

Reactor coolant system parameters are shown in Table 3-1.

\subsection{Auxiliary Systems}

A number of auxiliary systems are required to support the reactor coolant system. Major systems are listed below with a brief functional description.

Makeup and Purification System - Regulates inventory of the reactor coolant system during all modes of operation and removes corrosion products, fission products, and other impurities from the reactor coolant.

Decay Heat Removal System - Removes fission product decay heat from the reactor core during normal cooldown or following reactor trip and during shutdown, and provides cooling water injection to the reactor vessel and core under emergency conditions.

Emergency Decay Heat System - Removes heat from the reactor coolant system via the steam generators during accident conditions.

Chemical Addition \& Boron Recovery System - Transfers, stores, recovers and thereby changes concentration of bcric acid in the reactor coolant system during normal operation.

Reactor Plant Service Water System - Supplies cooling water to the reactor plant from the available water sources.

Component Cooling water system - Transfers heat from various sources in the reactor plant to the reactor plant service water system via heat exchangers.

Containment ${ }^{-}$drywe 11 Cooling system - Removes heat from the containment drywell atmosphere during both normal operating and emergency loss-of-coolant accident (IOCA) conditions.

Reactor Building. Ventilation System - Provides ventilation of various areas in the reactor building and controls release of radioactive gases to the environment via filters.

Radwaste Disposal System - Collects, stores, and disposes of all solid, liquid, and gaseous wastes generated by normal operation of the reactor plant. 


\subsection{Auxiliary Systems - (Continued)}

Post-LOCA Combustible Gas Control system - Injects Halon 1301 into containment following a LOCA to prevent ignition of hydrogen.

Sampling System - Provides a means of remotely sampling primary coolant, key auxiliary system effluents, and all waste gases.

Suppression Pool cooling System - Maintains the containment suppression pool water temperature and chemistry at required levels during normal and emergency conditions.

\subsection{Reactor Plant Instrumentation \& Control Systems}

The following sub-systems comprise the reactor plant instrumentation and control systems and provide for control, monitoring and safe shutdown of the reactor plant.

Integrated Control system

Nuclear Instrumentation system

Reactor Protection System

Non-Nuclear Instrumentation and Control systems

Engineered Safety Features Actuation System

Safety-Related Control and Instrumentation System

Control Rod Drive Control System

Incore Monitoring Systems

\section{2 .1 .2 .4 Containment}

The PE-CNSG nuclear steam system is enclosed by a containment vessel the purpose of which is to condense and contain the steam-water mixture that would discharge from a postulated pipe break in the PE-CNSG.

The pressure-suppression containment (Figure 3-5) comprises a dry well into which the steam-water mixture expands after being discharged through the break, a wet well containing a large volume of water for condensing the steam as it discharges through the vent pipes, and a suppression system air space into which the containment non-condensable gases are collected after condensation of the steam in the wet well. Because the steam is condensed in the wet well, the PE-CNSG containment can be relatively small and still produce a reasonably low design pressure (105 psig). The large PWR nuclear power plants do not have pressure-suppression containments and, thus, with the rapid release of steam-water mixtures, the containment must be very large to maintain a reasonably low design pressure.

Because of the compact reactor design and resulting suitability of pressure suppression containment as well as improved loss-of-coolantaccident (LOCA) transient characteristics of the PE-CNSG, the relatively small containment can be housed within the reactor service building in contrast to the loop-type PWRs where the containment is a large separate structure outside the reactor service building. The pressurecontaining wall of the cylindrical PE-CNSG containment is 38 feet in diameter by 64 jeet high. The containment is free-standing and bottom- 


\subsection{Containment - (Continued)}

supported. An upper closure is provided for refueling, inspection, and maintenance. The containment has a normal personnel access at about mid-height, which is closed and sealed during operation. Access to the area under the reactor vessel and through the Nss/containment load-bearing support plate is provided by an access tunnel and a bolted containment closure.

The PE-CNSG containment is surrounded by a concrete biological shield which protects against direct radiation from the PE-CNSG core and induced radioactivity in the primary coolant. The concrete biological shield and the reactor service building itself provide two additional barriers to the containment for minimizing the accidental release of radioactivity to the environment. This is accomplished by controlling and isolating these areas and filtering the air that is released to the environment.

\subsubsection{Refueling, Maintenance, and Inspections}

The PE-CNSG fuel handling systems provide a safe, effective means of transporting and handling nuclear fuel from the time of its arrival at the plant in an unirradiated condition until its departure from the plant after post-irradiation cooling. Supporting systems have been designed to minimize the possibility of mishanding which could cause fuel damage or potential release of fission products.

The land-based PE-CNSG uses a conventional method of "wet" refueling where all operations are performed underwater. Underwater transfer of spent fuel assemblies will provide an effective, transparent radiation shield as well as a reliable cooling medium for removal of decay heat. Use of borated: water provides an added safety margin that will ensure subcritical conditions during refueling. Both new and spent fuel storage are housed in the fuel storage pool located next to the reactor containment inside the reactor service building.

The refueling outage is estimated to be 30 days if performed every 12 months, 35 days if performed every 18 months, and 40 days if performed every 24 months. The outage days shown include not only the refueling time but also time for maintenance and inspections. The additional outage time for longer refueling cycles is for estimated additional maintenance due to the longer plant operating time.

The PE-CNSG has been designed to be highly accessible for the performance of Code-required inservice inspection. Through the use of remote examination devices, all the welds and components requiring examina tion under the rules of Section XI of the ASME Boiler and Pressure Vessel Code, 1975 Winter Addenda, can be examined.

The initial inspection results obtained prior to critical operation of the plant form the base map against which future inspection results will be compared. Any subsequent changes in inspection results recorded 


\subsubsection{Refueling, Maintenance, and Inspections - (Continued)}

During the post operational inspection will be compared and evaluated agaizst the original base data and Code-established fracture mechanics criteria. Manual scanning will be used wherever possible to provide economical inspection.

Piping and other associated components are designed taking maximum inspectability into account. Access requirements for the performance of inservice examinations required by the code are well defined and will be applied to the maximum extent possible consistent with effective design and operation of the Nuclear steam Plant.

The PE-CNSG is cesigned to facilitate any maintenance that may be required. In adaition, the equipment is arranged for minimal radiation exposure to personnel during maintenance or repair. For example, in the event that it becomes necessary to plug a defective steam generator tube, the straight-tube design of the steam generator facilitates the insertion and subsequent plugging of each end of the defective tube using remote plugging techniques. Tube plugging would be conducted during a refueling outage when the vessel head and upper flow distributor are removed. Sufficient water is added between the steam generator and the maintenance personnel so that radiation doses are acceptably low.

\subsubsection{Secondary/Tertiary Systems}

\section{2 .1 .4 .1 Introduction}

In the process heat applications, it is desirable to have an additional loop or separation barrier between the reactor coolant (primary system) and the process steam (tertiary system) to minimize the possibility of radioactive contamination of the process steam. Although primary-tosecondary system leakage is not expected, the possibility of activity in secondary system steam is not excluded as a conservative design consideration. To avoid any possible radioactive carryover to the process steam, a third loop or tertiary system is provided with process steam evaporators (herein referred to as reboilers) used to transfer heat from the secondary system. Although operational experience may indicate that reboilers can be eliminated from the design for certain applications, it is believed prudent to include them for initial plant des:-gn.

\subsection{Study Cases}

Five cases for supplying the process steam requirements of the process plant were devised and a reboiler system was designed for each case. Design points for each case are as follows:

Case. I - 810,000 \#/hr process steam @ 550 psig and 7500F, - Fig. 3-6

Case 2 - 1,000,000 \#/hr process steam a 550 psig and $750^{\circ} \mathrm{F}-\mathrm{Fig} \cdot 3-7$

Case $3-810,000$ \#/hr. process steam e 550 psig, saturated - Fig. 3-8.

Case 4 - Maximum process steam that CNSG will deliver e 550 psig saturated Fig. 3-9. 
3.2.1.4.2 Study Cases - (Continued)

Case $5-1,000,000 \# / \mathrm{hr}$ process steam \& $550 \mathrm{psig}, 750^{\circ} \mathrm{F}$, with the CNSG operating at maximum power and the excess secondary steam to be used in a condensing turbine for electric power generation - Fig. 3-10.

Cases 1, 3 and 5 require an oil-fired superheater to be located in the user's process plant in order to superheat the process steam to $750^{\circ} \mathrm{F}$.

\subsection{Secondary System Description}

The major components of the system are the reboilers and feedwater heaters. The reboilers are U-tube and shell heat exchangers with the secondary steam from the CNSG condensing in the tubes and the process fluid heated on the shell side.

A large drain reservoir is located in the condensate line between the reboilers and feedheater. This tank has a volume of $2500 \mathrm{ft}^{3}$ and serves as a four-fold purpose. This is: (1) to ensure a supply of fluid to the feedheater in the liquid state, (2) to provide the CNSG system with a 5-minute makeup supply (at maximum flow conditions) of steam generator coolant should it be required in an emergency situation, (3) to provide a location for hydrogen injection for control of oxygen in the secondary system and (4) to provide a water level which may be monitored to determine makeup requirements. During normal operation, the condensate enters the tank from the reboilers via spray nozzles. The tank contains approximately $2000 \mathrm{ft}^{3}$ of stored water, and the hydrogen gas collects above the water. The spray system provides adequate exposure of water to hydrogen gas to ensure entrainment of the hydrogen in the water. The water ultimately passes through the tank to the feedwater heaters.

The feedwater heaters are used to cool the secondary water on the tube side while heating the process fluid on the shell side. All secondary water from the tube sides of the reboilers passes through the feedheaters.

The water leaves the feedheaters and enters the suction side of the motor-driven centrifugal feedwater pump. The system has two feedwater pumps, each with $100 \%$ capacity, to provide full backup capability. The pump increases the water pressure and discharges the water to the steam generators.

Systems are provided for filtration and purification of the secondary water. An electro-magnetic filter is located downstream of the feedwater pumps. This system is designed to handle $100 \%$ of the flow. The system filters the CNSG secondary water to eliminate suspended magnetic solids formed during plant operation. The demineralization system is located downstream of the electromagnetic filter. The system is designed to handle up to $100 \mathrm{gpm}$ of the system flow. The water first passes through a letdown cooler where the temperature is reduced from $400 \mathrm{~F}$ to $120 \mathrm{~F}$. The demineralizer system is used for purification of both the letdown fluid and the makeup water. 


\subsection{Secondary System Description - (Continued)}

The system is intended for intermittent use depending on water quality conditions. The demineralizer discharges directly to the suction side of the feedwater pumps. Secondary system sample lines are provided on both the influent and effluent sides of the demineralizer and are used to monitor both the need for and effectiveness oi the demineralizer.

The makeup system is tied directly into the deminerailization system. The makeup system is controlled by the level in the drain reservoir. Water is added by the makeup system through the demineralizer when the bypass system is in operation.

If the bypass Iine is not in use, water is added directly to the feedwater pump inlet piping.

A chemical addition system is included for corrosion control. This system consists of hydrazine addition for oxygen control and ammonia addition for pF control. The system is manually controlled, based on input from sample readings, and used during system heatup and cooldown. Provisions for hydrogen addition have been made in the drain reservoir to suppress oxygen generated in the water by radiolysis as the water passes through the CNSG steam generator near the nuclear core. The oxygen concentration in the system is controlled to a maximum $7 \mathrm{ppb}$.

\subsection{Tertiary System}

The tertiary system steam is produced on the shell side of the reboilers. Tertiary system water is returned from the user's process at $280 \mathrm{~F}$ and 67 psia. It then enters the suction side of the tertiary feed pump. The system has two feed pumps, each with 1008 capacity. The water is increased in pressure by the pumps and then enters the shell side of the feedwater heaters, where it is partially heated while cooling the secondary fluic. At the feedwater heater outlet, the fluid is ready to enter the shell side of the reboilers. Steam leaves the reboilers at saturated conditions, and is superheated for cases. 1,2 and 5 .

Solids buildup in the reboiler is controlled by biowdown. There is one blowdown cooler in the system with a common intake line connected directly to the shell side of the reboilers and discharging to the user. The continuous blowdown rate is $1 \%$ flow for control of solids.

The tertiary system fluid is sampled from the blowdown cooler discharge Iine. This method of sampling allows examination of effluent from the reboilers without affecting operation.

\subsection{System Control}

The CNSG reactor and reboiler systems are monitored and controlled by computer systems. The Operator Information system (OIS) computer provides display, logging, and alarm monitoring of reactor and reboiler systems. The OIS also provides diagnostic monitoring of other computer systems. "The Plant Contröl system (PCS) controls the PE-CNSG and re- 


\subsection{System Control - (Continued)}

boiler by monitoring plant variables and iniliating control action as well as by interfacing with the control console and OIS.

\section{Secondary system}

Reboiler heating steam is supplied by the main steam from the CNSG compartment. The heating steam is controlled via control valves that regulate the flow to the reboilers. These control valves are monitored and controlled by the plant control system. If the heating steam demand becomes too low for the control valves to operate satisfactorily, one or more of the reboilers can be valved out of service. The process steam demand also regulates reactor power level. The secondary fluid level in the drain reservoir is monitored and controlled by the plant control system via the makeup supply. The piant control system automatically adjusts the makeup water supply valve to allow more or less flow to the secondary system, which ultimately adjusts the level in the drain reservoir to a preset value.

Feedwater flow is controlled by the action of the feed control valve and pumps in response to signals from the plant control system. In steady-state conditions, the feed flow matches steam flow, but the flows may differ during transients.

The flow through the demineralization system is controlled by the operator through the operator information system. Temperature sensors measure effluent temperature of the letdown cooler, and flow rate is determined with.a flow orifice. These values are monitored by the plant control system and, if the effluent temperature rises above $120 \mathrm{~F}$, flow is stopped to avoid damaging the resins in the demineralizer. The pressure drop through the demineralizer is monitored by the OIS. This pressure measurement along with sample readings of both the influent and effluent are used to determine the need for demineralizer resin replacement.

The secondary chemical addition system is monitored by the operator information system. The ammonium hydroxide tank level is measured and transmitted by this system to the control room. The flow rates of both the hydrazine and ammonium hydroxide adcition system are monitored by the operator information system and the rates are controlled manually by the operator.

\section{Tertiary System}

Two identical redundant feedwater pumps are included in the system design. During normal operation, one pump is running while the other remains idle. If the operating pump should fail, flow will be picked up by the idle pump. Both pumps have built-in recirculation loops with flow orifices. 
Tertiary system - (Continued)

The feedwater pumps discharge to the shell side of the feedwater heater where the fluid is heated before going into the reboilers. The feedwater to the reboilers is controlled by individual control valves; each valve is controlled by its respective reboiler water level. The level controller maintains the liquid level slightly above the tube bundle to prevent tube dry-out and excessive static pressure in the shell. If, during low-flow demand periods, the control valves fail to operate satisfactorily, one or more reboilers can be valved out of service. As the control valves are closed, the feedwater pump head increases and flow in the recirculation loop around the pumps increases.

Flow to the blowdown cooler is controlled manually by individual valves on each blowdown line. A flow orifice, located just downstream of the blowdown cooler is used by the operator information system to monitor flow. The blowdown fluid is cooled to $120 \mathrm{~F}$ by the cooler and flow is controlled remotely by an oIs-actuated throttle valve. The blowdown is discharged to the user's water system. Reboiler sampling is accomplished by a small line coming directly off the blowdown line. This system allows intermittent or continuous monitoring of samples from the reboilers.

\subsection{Condensing Cycle Turbine - Generator System}

A schematic flow diagram for the turbine generator system for nuclear case 5 is shown in Figure 3-10. Of the 555,000 lb/hr of secondary steam directed to the turkine generator system, only 412,000 1b/hr passes through the turbine to the condenser with the remaining being used for feedwater heating under normal operating conditions. The turbine generator consists of a $3600 \mathrm{rpm}, 34$ MWe single flow non-reheat steam turbine with a direct coupled, $3600 \mathrm{rpm}$, three phase, 60 hertz, air cooled synchronous generator. The exhaust steam from the turbine is condensed in a condenser designed at $3.5^{\prime \prime} \mathrm{Hg}$ vacuum. The turbine is designed to operate satisfactorily without external moisture separators. Condensate from the condenser is pumped to the deaerator by two $650 \mathrm{gpm}$ condensate pumps. The deaerator is an open heat exchanger tank which directly mixes the condensate with the remainder of secondary steam directed to the turbine generator system. This feedwater joins with the secondary feedwater from the process energy system and is pumped to the steam generators by means of secondary feed pumps. Condenser heat is removed by the circulating water systems. This heat is then rejected to the atmosphere by a single cell mechanical draft cooling tower.

\subsubsection{Construction Techniques}

The consolidated plant layout described in section 3.2.1.1 lends itself to construction techniques that use a fixed lifting device, such as a 300 ton stiff-leg crane, for all major lifts. This device will help to speed construction by making heavy lifts readily available and facilitating component placement. 


\subsubsection{Construction Techniques - (Continued)}

The load-bearing structure for the entire raactor complex is a steel plate 4-inches thick and 38 feet in diameter. This plate is shop-fabricated to include the coce-welded, 4-foot-high bottom segment of the reactor containment cylincirical sections.

The reactor vessel support pedestal upon which the skirt-supported reactor vessel will be positioned is centrally located on this plate. Webbing structures distribute the load from the vessel support pedestal to the support plate. The prefabricated, stress-relieved support plate and attachments are transported to the site, set on the reactor service building concrete base, jacked level, and grouted into position with cement. The reactor support pedestal is then ground to reactor vessel mounting flatness requirements.

The upper portion of the 38-foot-diameter, 54-foot-high containment vessel structure is shop-fabricated. This large containment segment would be lifted into position and circle-seam welded to the loadbearing base plate segments to form the containment vessel. Major components can then be lifted and placed, and the concrete shielding can be poured. The outer steel containment wall is covered with crushable material and is used as an inner form for the shield wall concrete to facilitate construction. The crushable material separates the concrete and steel and provides space for differential expansion and contraction. An access tunnel under the load-bearing base plate permits access to the bottom head of the reactor vessel and to incore instrumentation guide tubes and nozzles located there.

The reactor vessel is transported to the sice in one piece, except for the head. The reactor vessel internals are prefitted to eliminate major field assembly problems.

\subsubsection{Coal Fueled Steam/Power Plant}

\section{2 .2 Plant Layout}

The study plant layout is shown on Figures $3-12$ and $3-13$. The area for the coal facility was designated by Du ?ont and PSE did not attempt to optimize the location.

The site layout shows the maximum land usage anticipated for the size coal plant. The largest steam turbine generator, including a substation, condenser and cooling tower is shown, although this equipment does not apply to all study cases. Wyoming coal was used to size the coal storage pile and two flue gas desulfurization (FGD) systems with a bypass are shown also. At the time the estimates were finalized the FGD system was not required for firing Wyoming compliance coal.

Although the FGD system is shown on the layout it was not included in the cost estimate for the wyoming coal cases. Schematics of the flue gas treatment systems are shown in figures 3-14 and 3-15. 


\subsubsection{Plant Layout - (Continued)}

No pilings have been used at the site in the past and land subsidence has not been a problem. Based on this information and the fact that the foundations for the coal plant would be similar to existing foundations at the site, no pilings were included.

\subsubsection{Study Cases}

Eight cases were selected for this study; four high-sulfur coal cases and four low-sulfur coal cases. The energy balance diagrams show the major components of each study case, the design steam conditions, the generator power output, auxiliary power load, and fuel requirement at a process steam load of $700,000 \mathrm{lb} / \mathrm{hr}$ and the maximum process steam load of $1,000,000 \mathrm{lb} / \mathrm{hr}$. The following is a brief description of each study case:

\begin{tabular}{|c|c|c|c|c|c|c|c|c|c|c|c|}
\hline \multirow[b]{2}{*}{$\begin{array}{l}\text { CASE } \\
\text { No. } \\
\end{array}$} & \multirow[b]{2}{*}{ COAI } & \multicolumn{3}{|c|}{ BOILER DESIGN CONDITICiIS } & \multicolumn{6}{|c|}{ LEVELIZED ANNUAI CONDITIONS } & \multirow[b]{2}{*}{$\begin{array}{l}\text { ENERGY } \\
\text { BALANCE } \\
\text { DIAGRAM }\end{array}$} \\
\hline & & $10^{3}$ EL/h/ & $\begin{array}{l}\text { PRESS. } \\
\text { PSIG }\end{array}$ & $\begin{array}{c}\text { TEMP } \\
O_{F} \\
\end{array}$ & $\begin{array}{l}\text { GENERATOR } \\
\text { CYCLE } \\
\end{array}$ & $\begin{array}{c}\text { ELWW } \\
10^{3} \mathrm{Ib} / \mathrm{hx} \\
\end{array}$ & $\begin{array}{l}\text { PRESS } \\
\text { PSIG } \\
\end{array}$ & $\begin{array}{c}\text { TEMP } \\
O_{F} \\
\end{array}$ & $\begin{array}{l}\text { NET } \\
\text { MW }\end{array}$ & $\begin{array}{c}\text { COOAL } \\
10^{6} \mathrm{Btu} / \mathrm{hr}\end{array}$ & \\
\hline 1. & ILLINOIS & 1,000 & 580 & 750 & - & 723 & 550 & 750 & - & 1.008 & $3-16$ \\
\hline 2. & WYOMING & 1,000 & 580 & 750 & - & 723 & 550 & 750 & - & 1.029 & $3-17$ \\
\hline 3. & ILINNOIS & 1,000 & 580 & 750 & COND & 723 & 550 & 750 & 10.9 & 1,288 & $3-18$ \\
\hline 4. & WYOMING & 1,000 & 580 & 750 & COND & 723 & 550 & 750 & 18.3 & 1,315 & $3-19$ \\
\hline 5. & ILLINOIS & 1,060 & 1,500 & 950 & BACK PRESS. & 723 & 550 & 750 & 9.0 & 998 & $3-20$ \\
\hline 6. & WYOMING & 1,060 & 1,500 & 950 & BACK PRESS. & 723 & 550 & 750 & 9.9 & 1.019 & $3-21$ \\
\hline 7. & ILLINOIS & 1,000 & $1,5 n 0$ & 950 & BACK PRESS. & 723 & 550 & 750 & 36.1 & $1,38.0$ & $3-22$ \\
\hline 8. & WYOMING & 1,000 & 1,500 & 950 & BACK PRESS. & 723 & 550 & 750 & 38.3 & 1.409 & $3-23$ \\
\hline
\end{tabular}

All of the above data are based on two percent blowdown and a feedwater temperature O‡ $2800 \mathrm{~F}$.

\subsubsection{Design Criteria}

The design criteria for each major component of the steam/power plant is as follows.

\section{2 .2 .3 .1 CoaI Yard}

A 100-car unit train was selected as the method of coal delivery with a car positioner and a rotary car dumper used to unload the cars into an underground hopper and conveyor, which conveys the coal to the storage pile. The track length was sized at 6000 feet, which is capable of accomodating the 100-car unit train. It was assumed that enough trackage was available between the coal yard track and main line to store a full train prior to unloading. 


\subsection{Coal Yard - (Continued)}

The coal storage pile was sized for a 60 day supply of low-sulfur Wyoming coal. Three storage piles were used to keep the storage pile within the unit train track and to use a stacker and reclaimer with a standard span.

A separate stacker and reclaimer were specified to permit the simultaneous unloading of a unit train and the transport of coal to the plant. The stacker and reclaimer can be transferred to different piles by a cross track at one end of the coal yard.

Many design concepts are available for coal delivery and transport to the boilers. PSE selected a design which will provide an automated form of unloading and transport to the boiler. No attempt was made to optimize the design based on economics.

\section{2 .2 .3 .2 Boilers}

The boilers were specified for the conditions indicated on the energy balance diagrams. Auxiliary equipment was quoted with the boiler including pulverizers, FD Fan, ID Fan, Air preheater, feedwater controls and combustion controls.

\subsection{Electrostatic Precipitator}

The electrostatic discharge precipitator was specified on the basis of 85\% of the ash in the coal being converted to fly ash and entering the precipitator. The design discharge particulate emission level was specified at the EPA limit of 0.1 lbs. of particulate/106 Btu of fuel. This requires a precipitator which is more than $99 \%$ efficient. A flyash storage silo with 60 hour capacity was specified to permit flyash storage over weekends.

\subsection{Flue Gas Desulfurization (FGD) System}

A Iimestone slurry FGD system was specified for high sulfur coal plants to limit $\mathrm{SO}_{2}$ stack emissions to 1.2 lbs $\mathrm{SO}_{2} / 10^{5} \mathrm{Btu}$ of fuel which represents the EPA. new source limit in effect at the time of this study. This represents approximately 78 percent sulfur removal.' A single scrubbing train was estimated as well as a bypass system to allow unit operation during short-term scrubber outages. This system was selected over other competitive systems because it is the most widely used system today. However, PSE did not attempt to optimize the type of FGD system based on economics or reliability.

In the specified system the bypass duct allows addition of flue gas downstream of the scrubber to heat the flue gas leaving the scrubber above the saturation point to prevent corrosion. The limestone slurry FGD system produces a sludge effluent which will not set up and is unsuitable for a landfill. However, if the fly ash from the precipita- 


\subsection{Flue Gas Desulfurization (FGD) System - (Continued)}

tor is combinec with the sludge, as shown in Figure 3-24, the mixture can be used as a landfill. This method was used for the study cases. A limestome storage area has been included to provide a 30 day limestone supply. The limestone storage area was based on truck shipmerts of Iimestone.

\subsection{Bottom. Ash Disposal System}

This system was specified on the basis of 25 응 of the ash in the coal being convertec to bottom ash. The bottom ash is collected in hoppers at the bottom of the boiler. From there it is sluiced to a landfill in the area near the coal storage pile.

\subsection{Steam Turbine Generator}

Steam turbines were specified for the steam conditions shown on the energy balance diagrams and direct-connected to a hydrogen cooled synchronous generator rated at 3600 RPM, 3 phase, 60 Hertz, 13.8 KVA and .90 power factor with a power output as shown on the energy. balance diagrams. Power from the generator was stepped up to a transmission voltage of $23 \mathrm{kV}$ and connected to the existing substation PPS3. A station service transformer was included to supply coal plant auxilliaries. A separate tie from PPS3 was made to supply the auxiliaries if the turbine is shutdown.

\subsubsection{Construction Schedule}

A construction schedule for a typical study case is presented in Figure 3-24. 


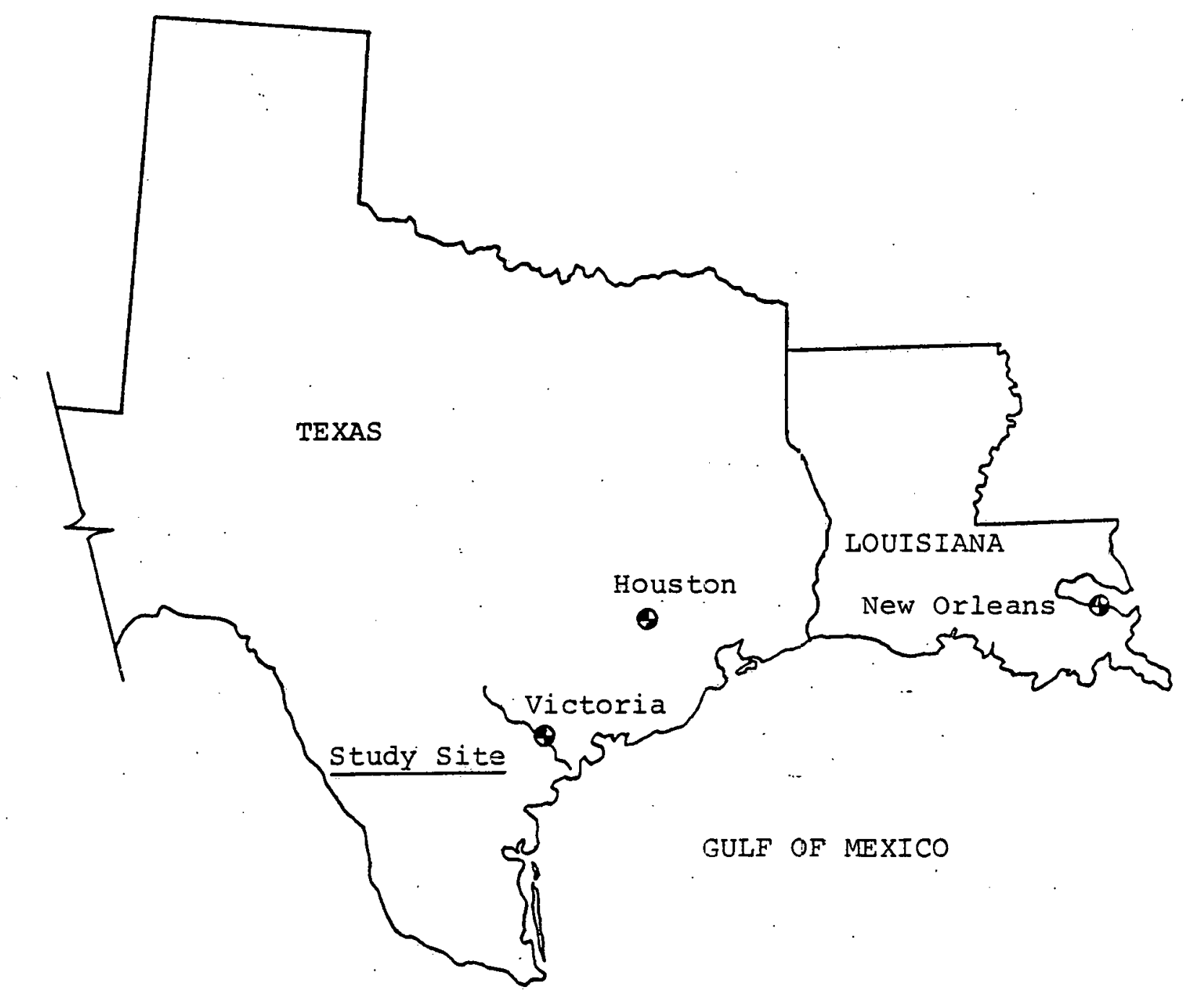

Figure 3-1 - GEOGRAPHIC LOCATION OF THE STUDY SITE 


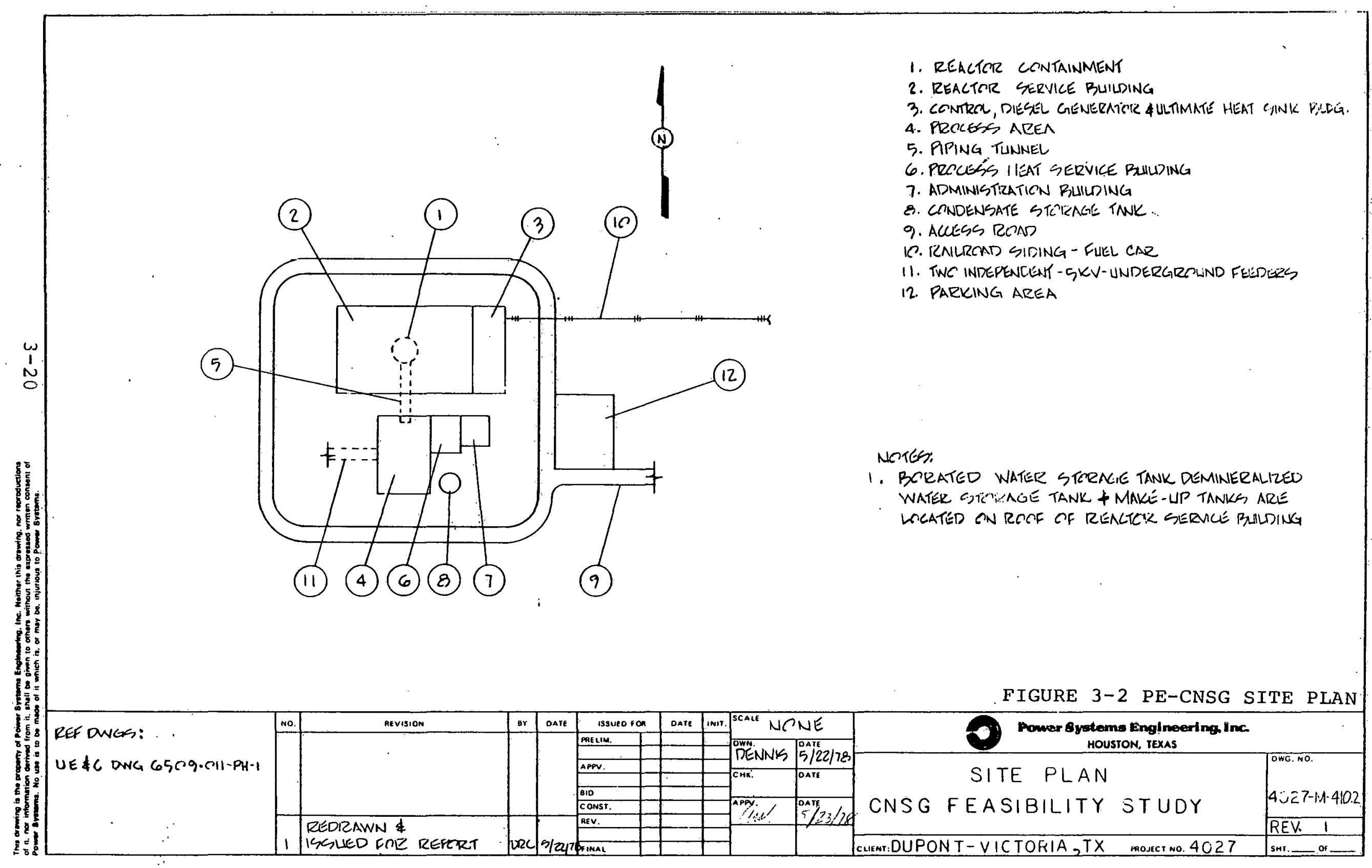




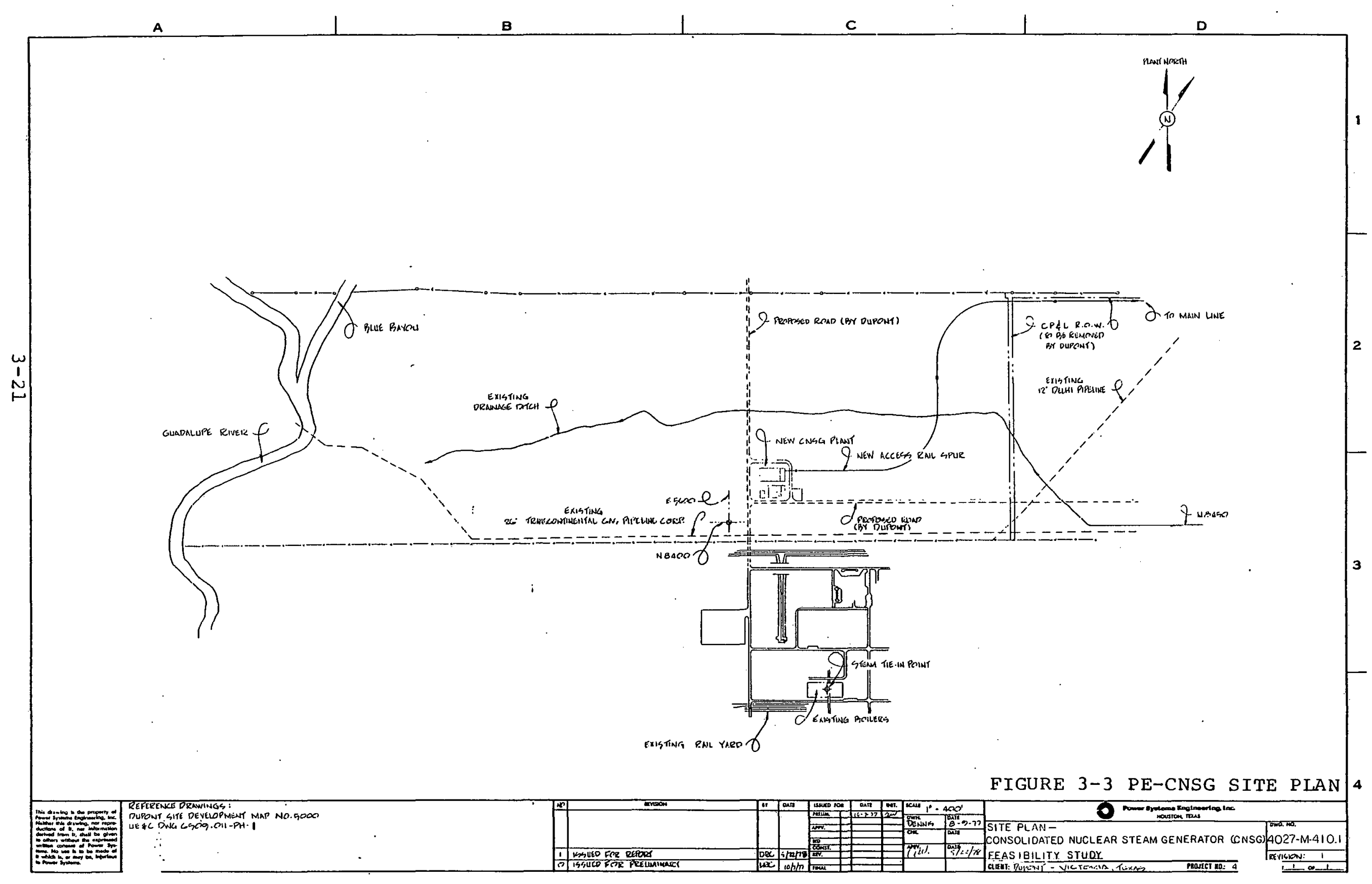


Figure 3-4 PE-CNSG Reactor Vessel

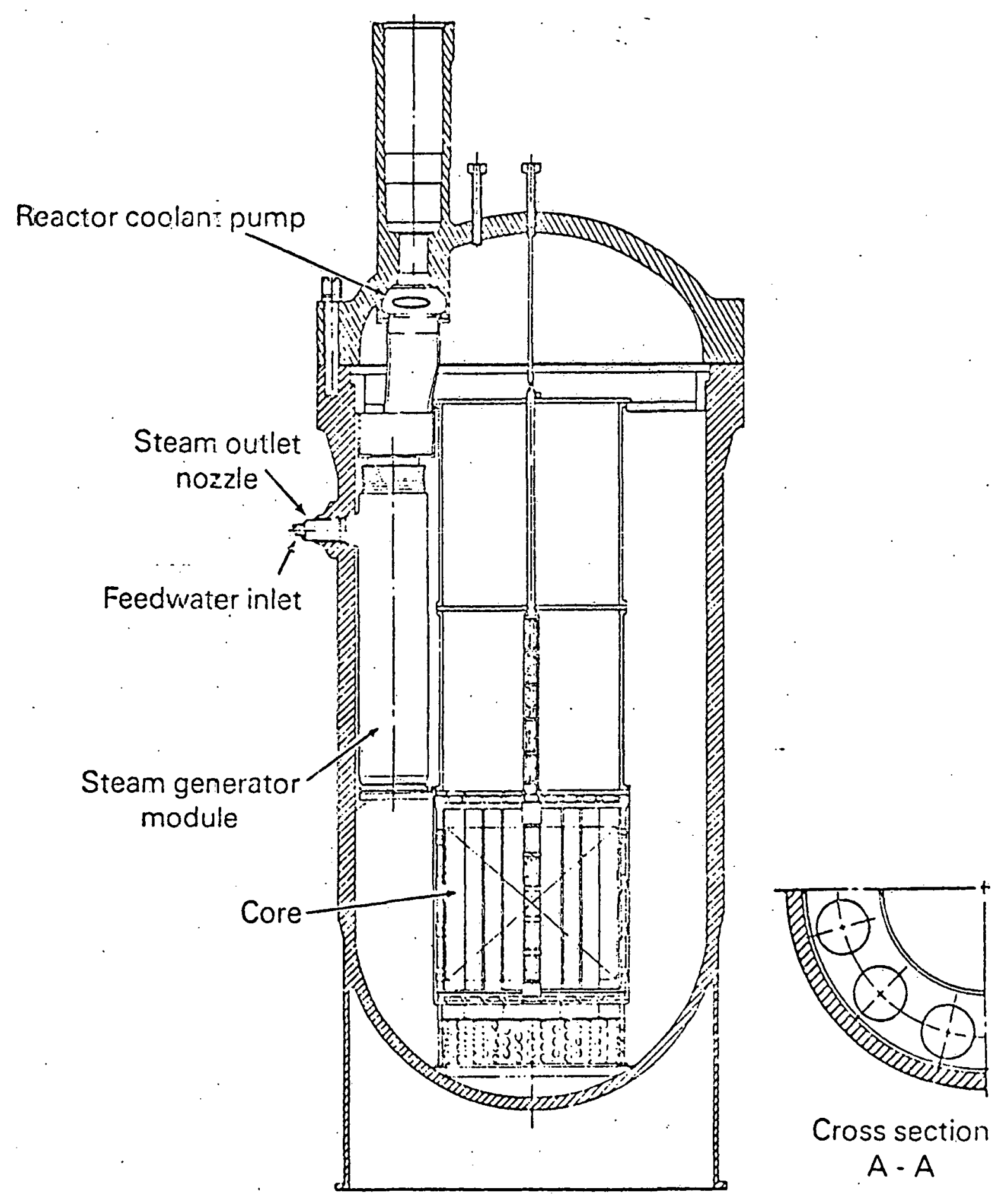




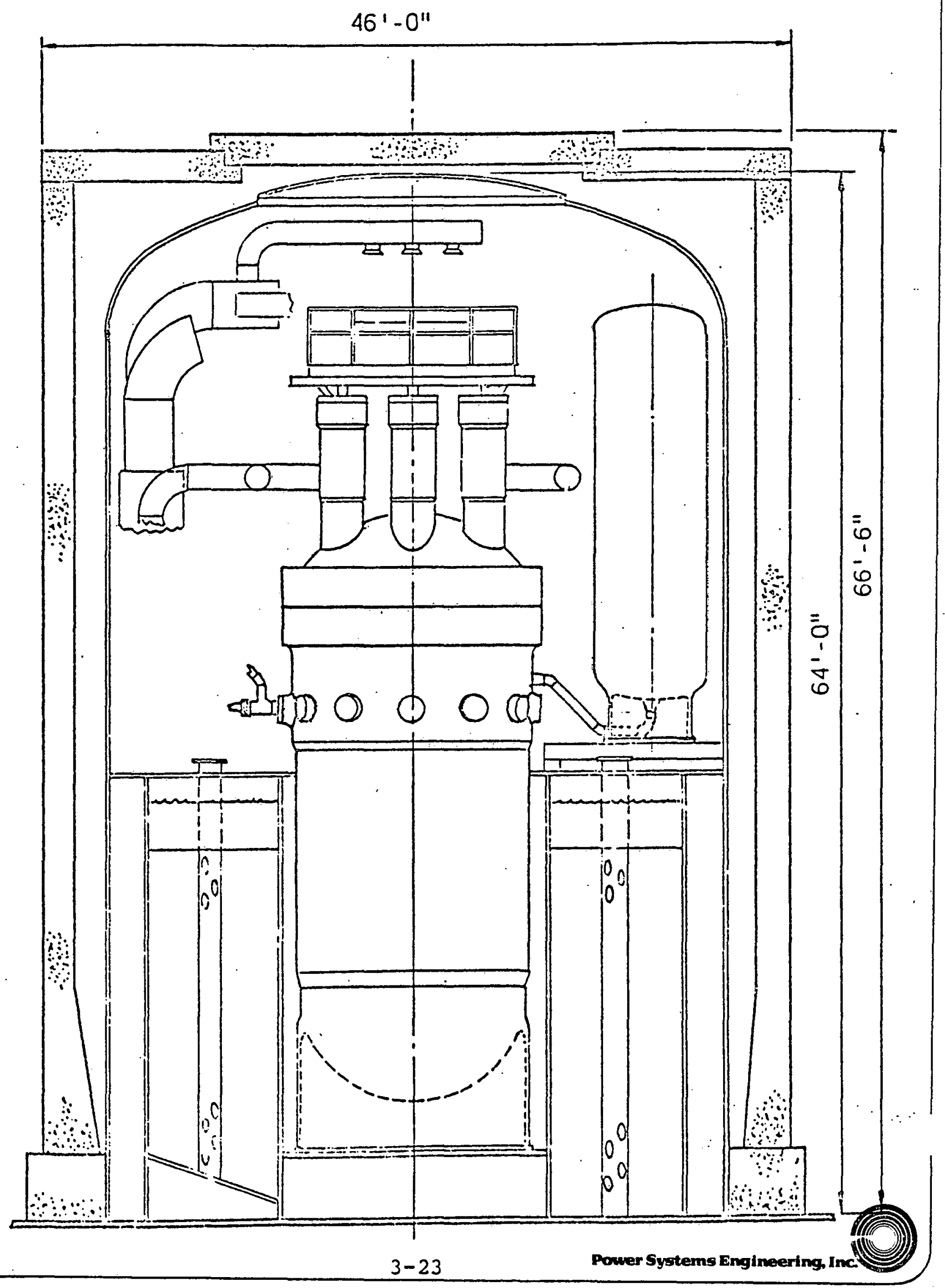




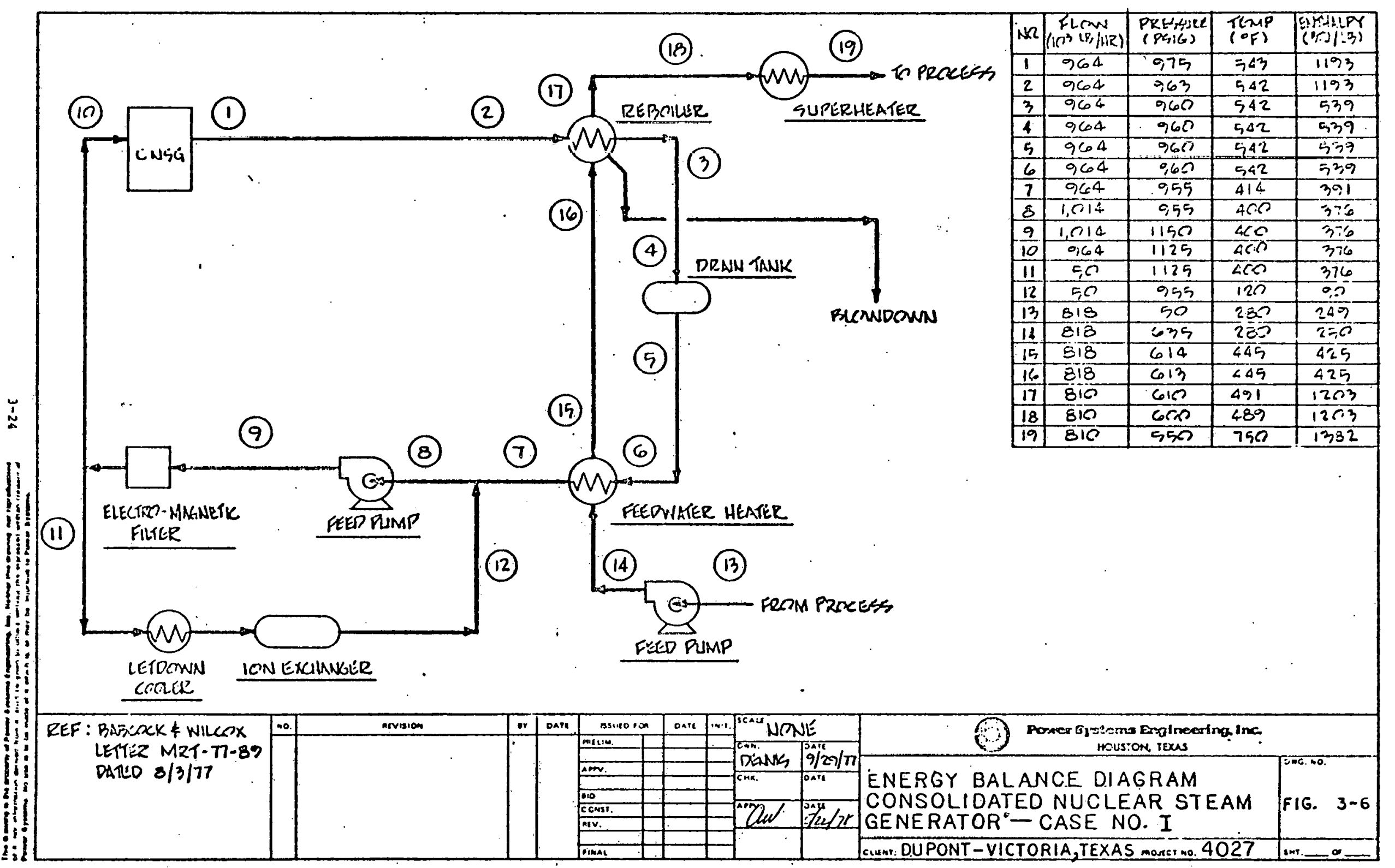




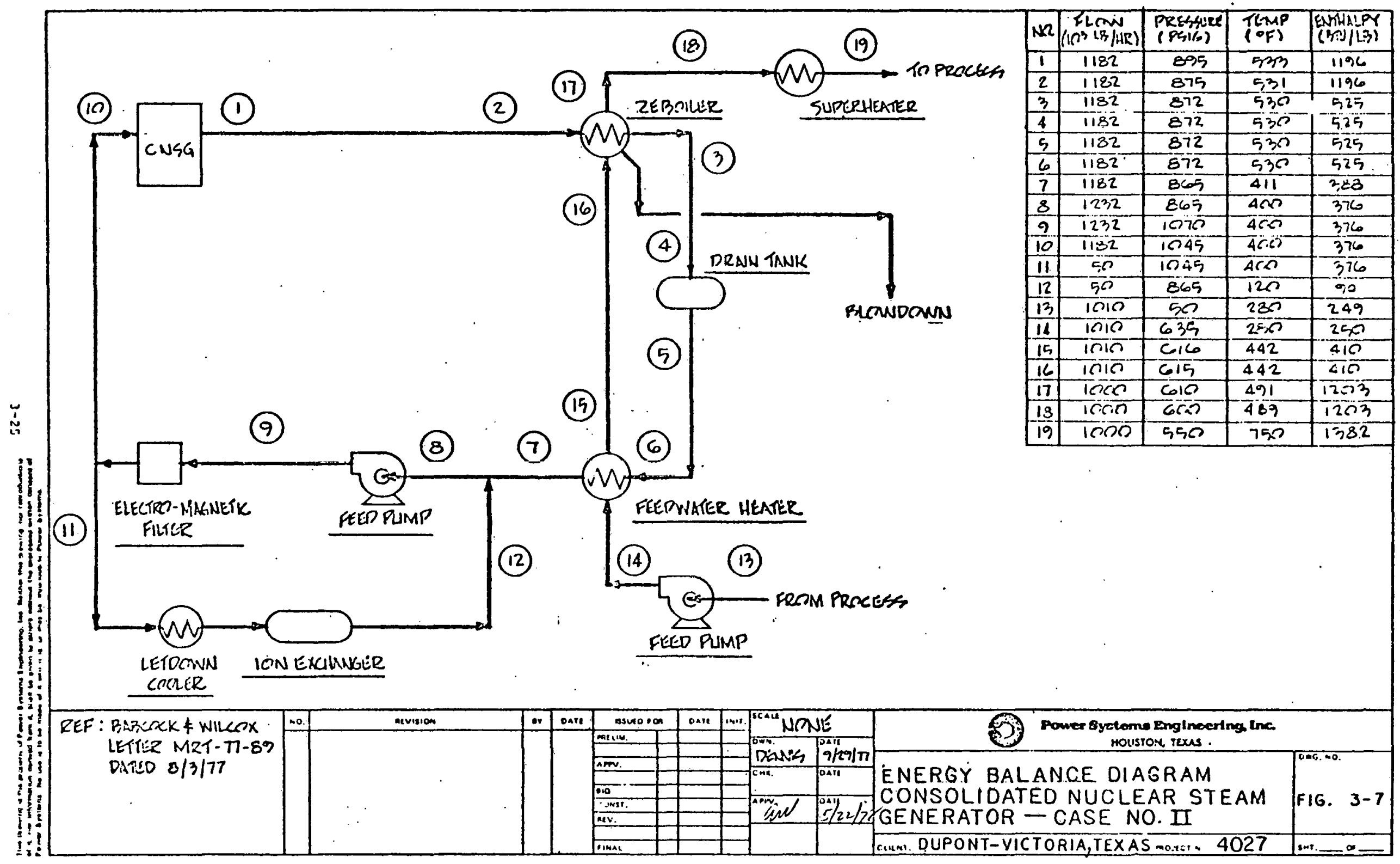




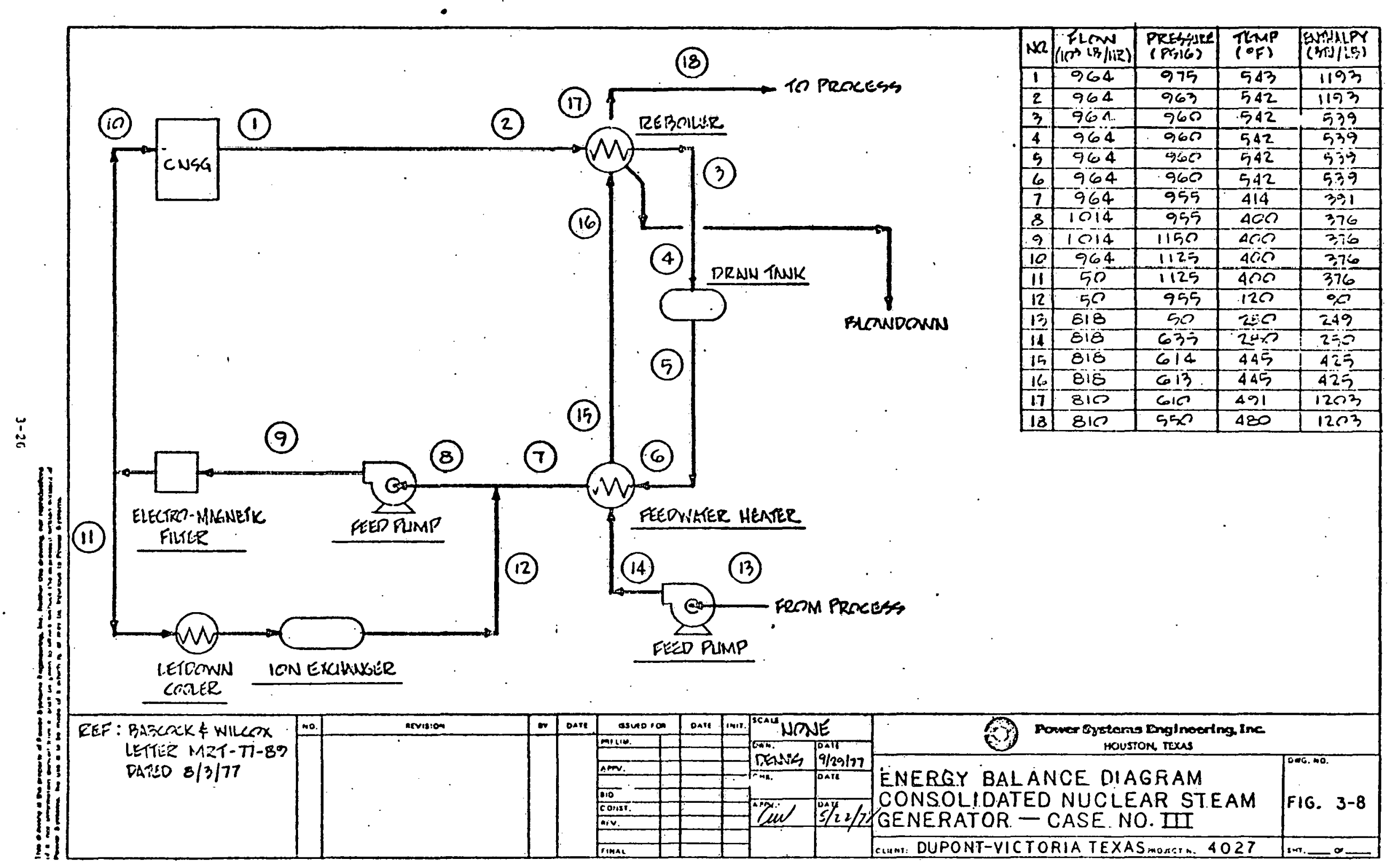




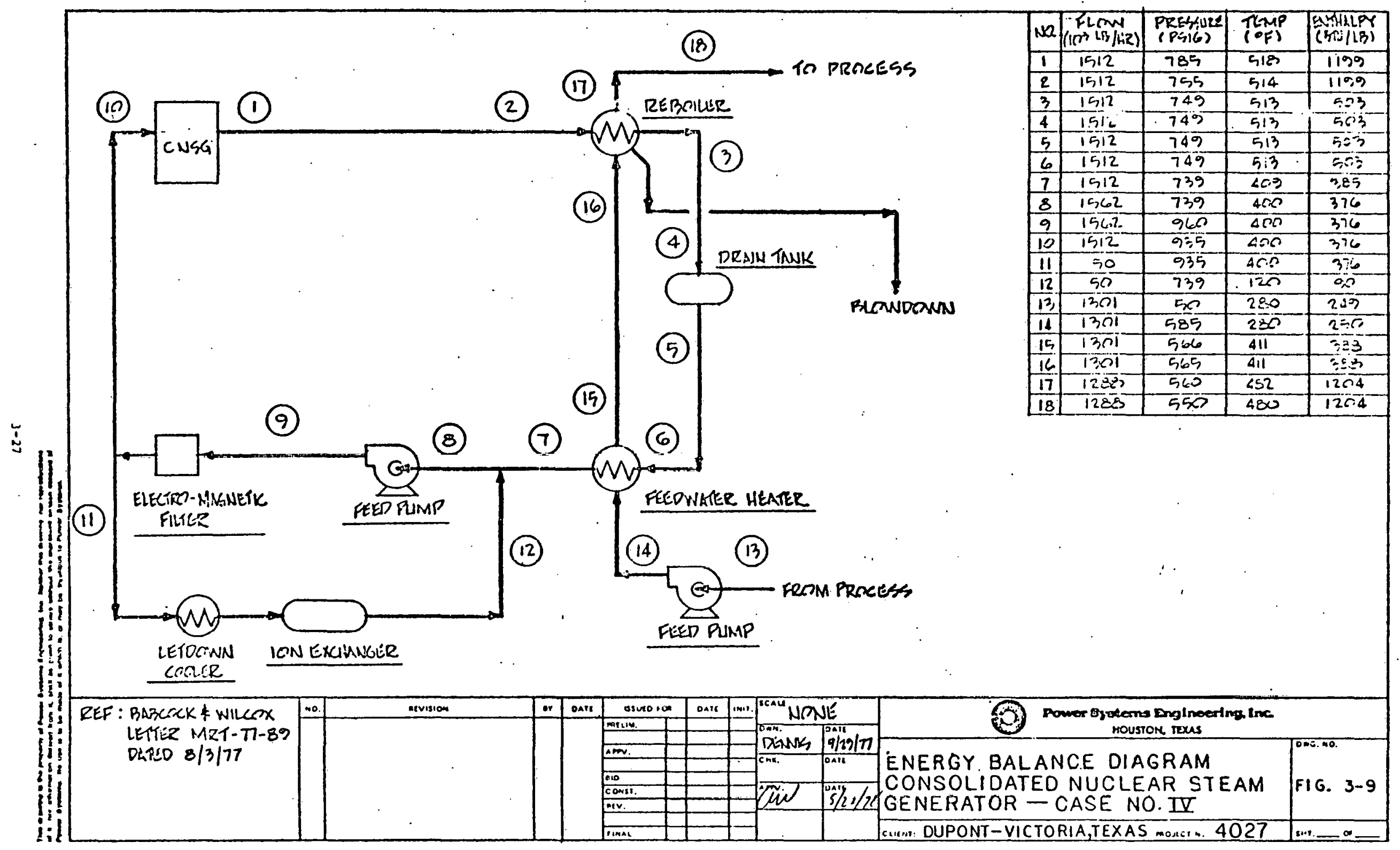




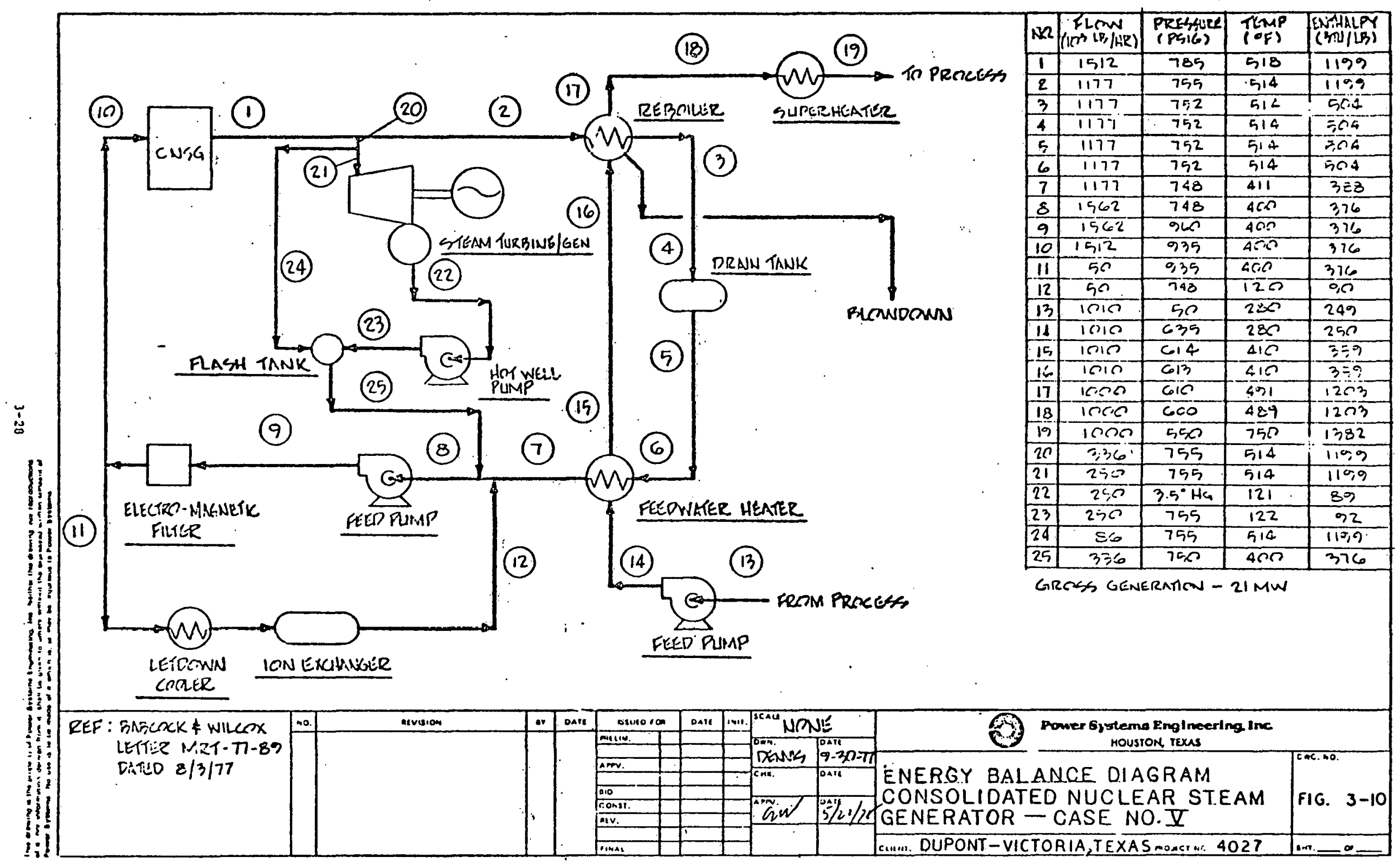


FIGURE 3-11 - NUCLEAR PLANT NTI OF A KIND CONSTRUCTION SCHEDULE

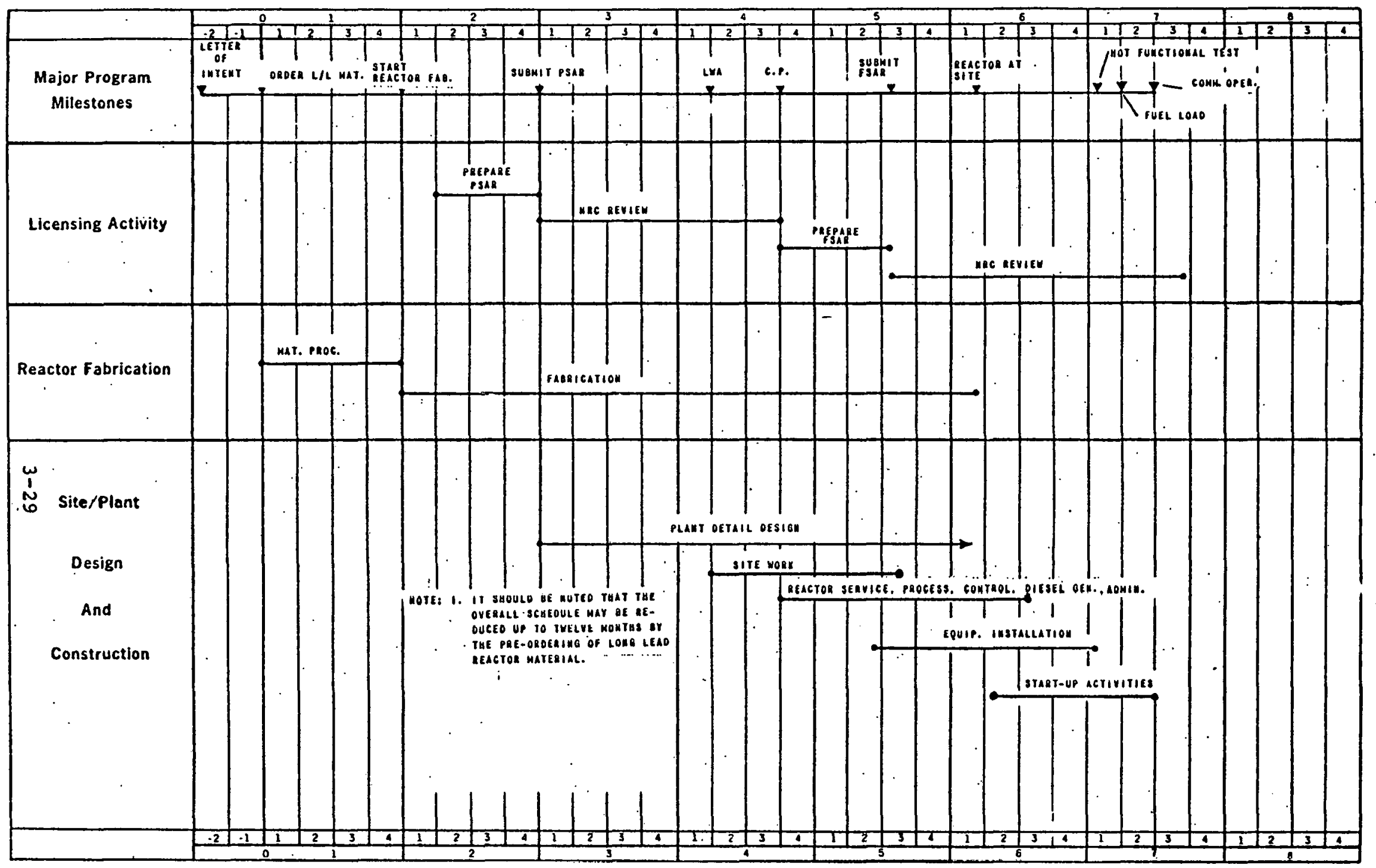




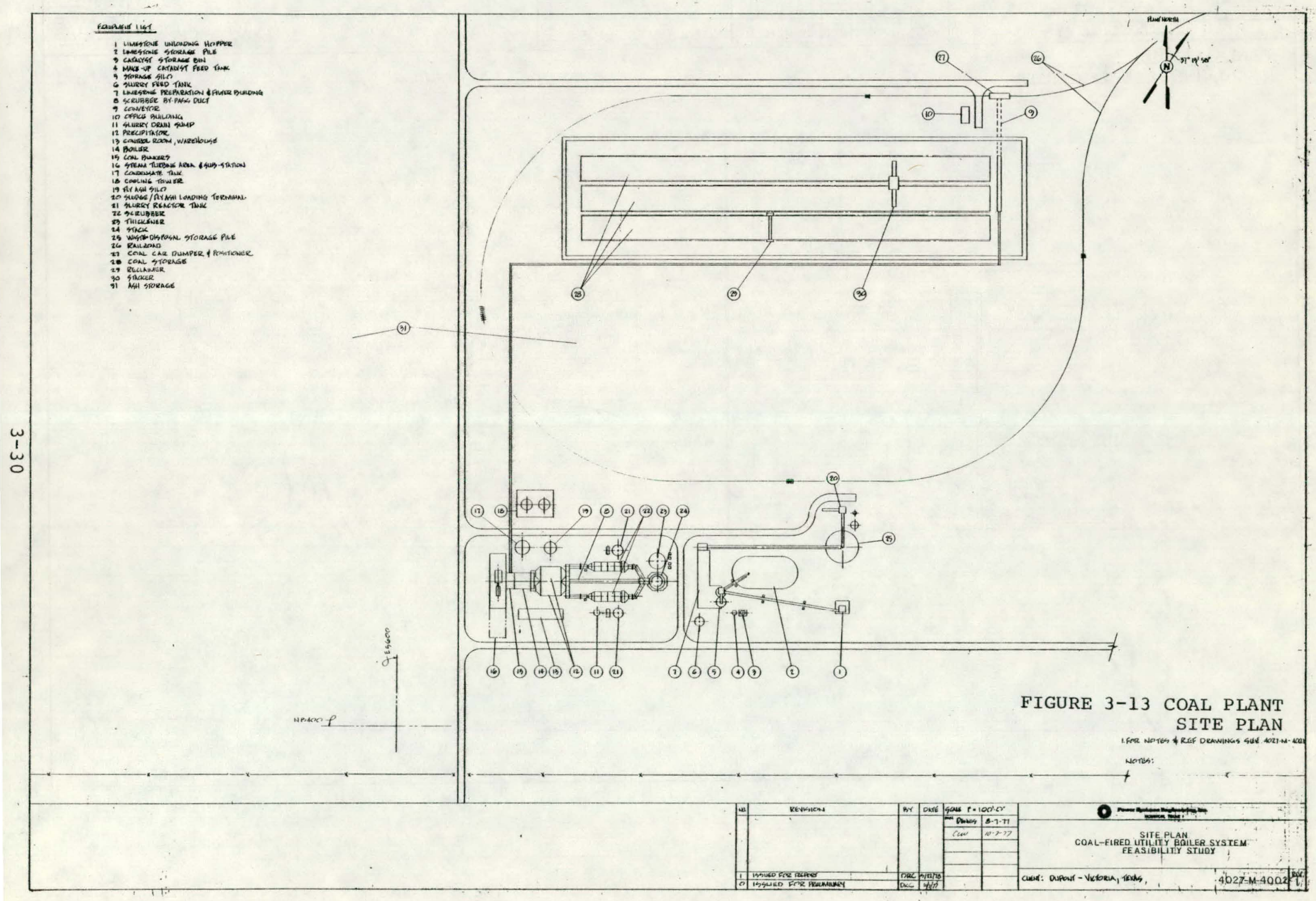


A

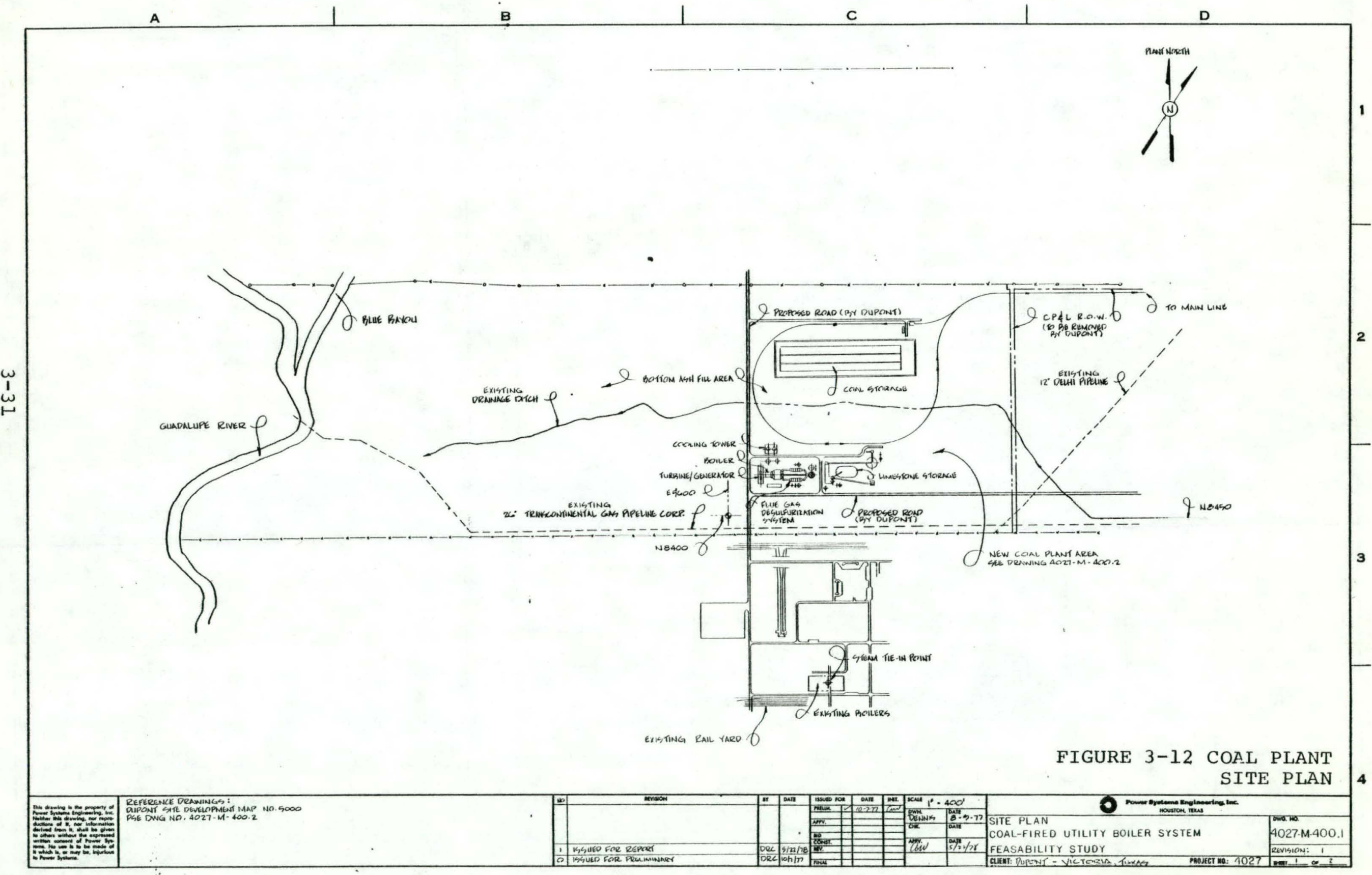




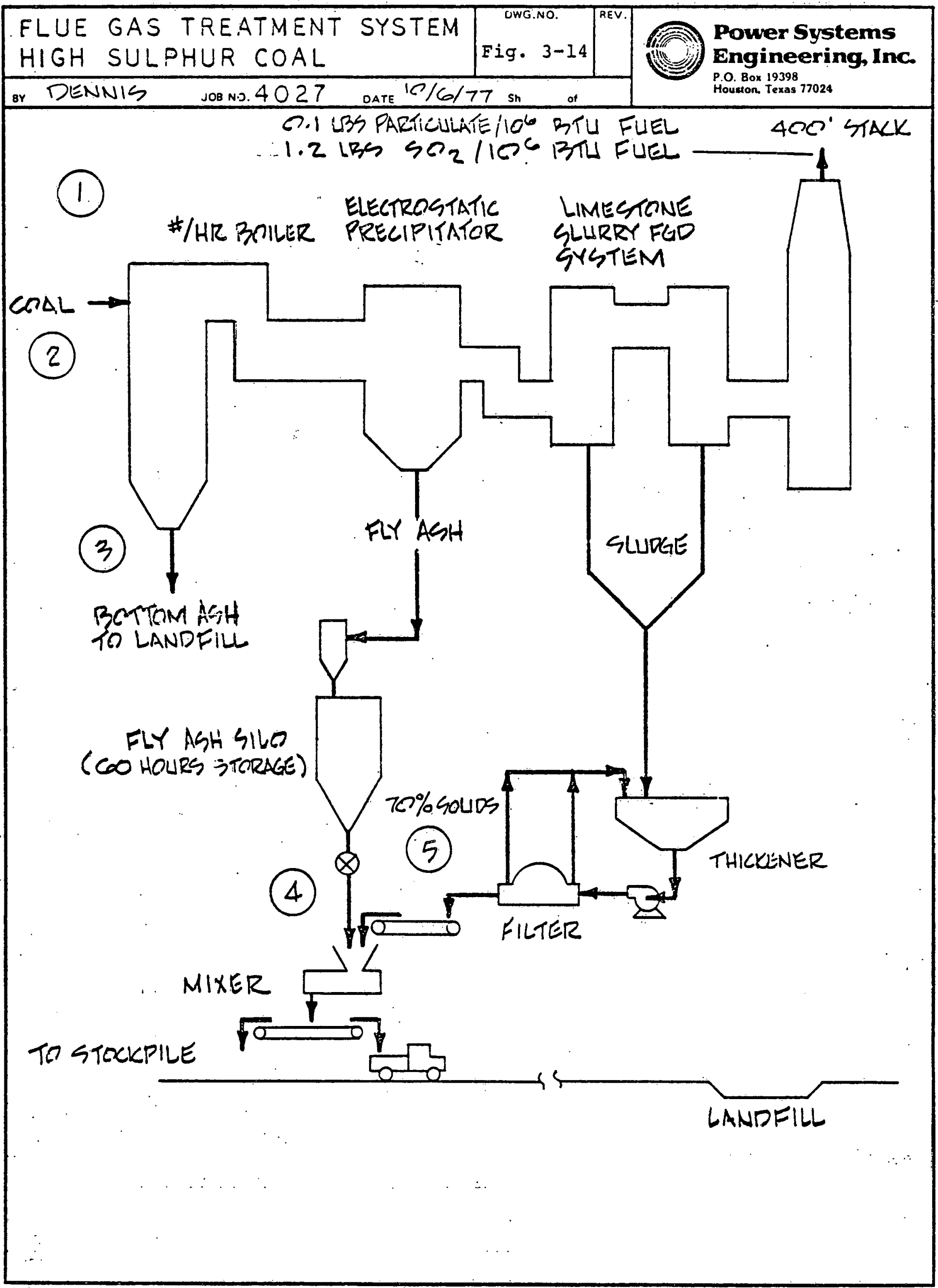




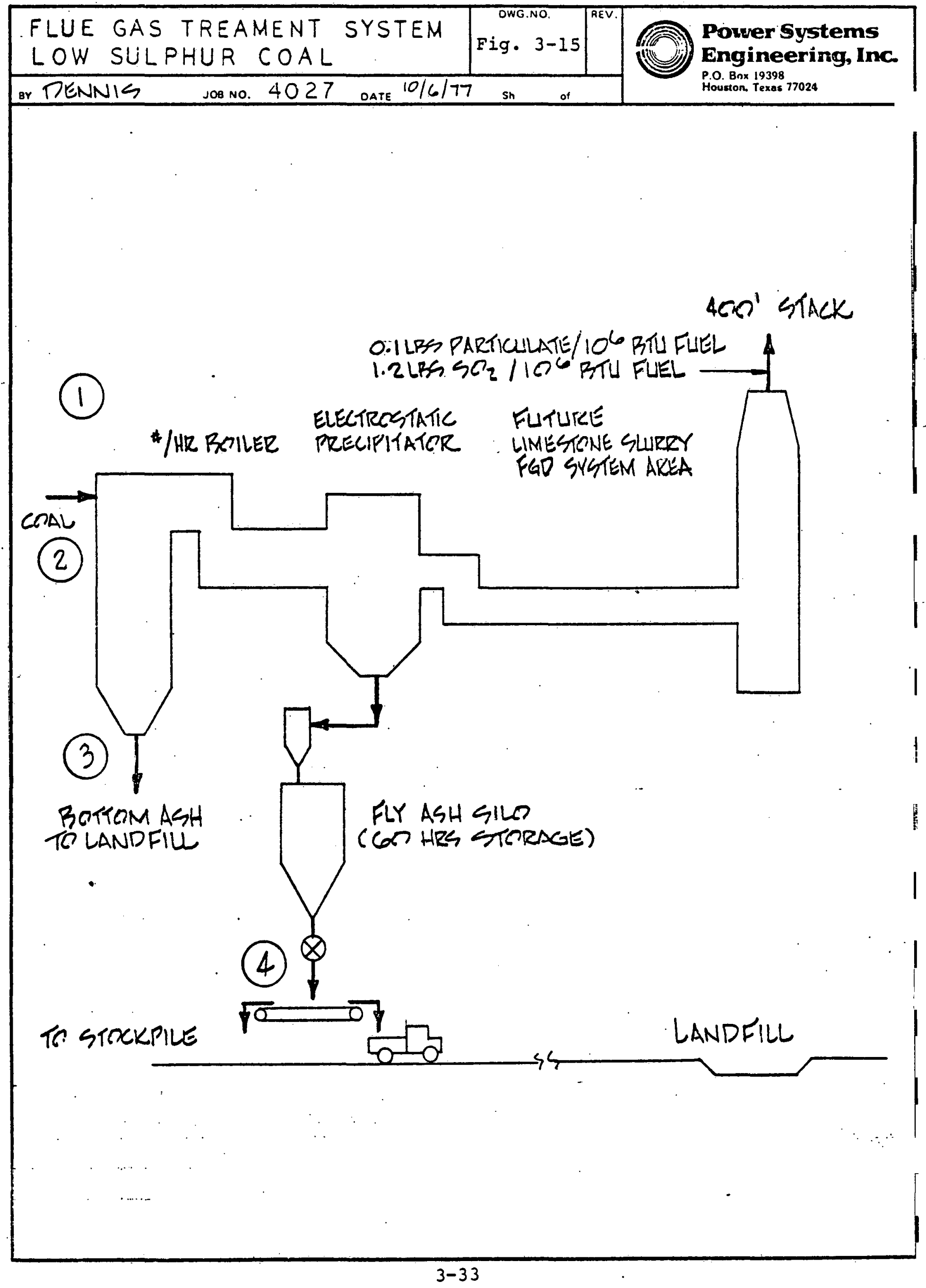




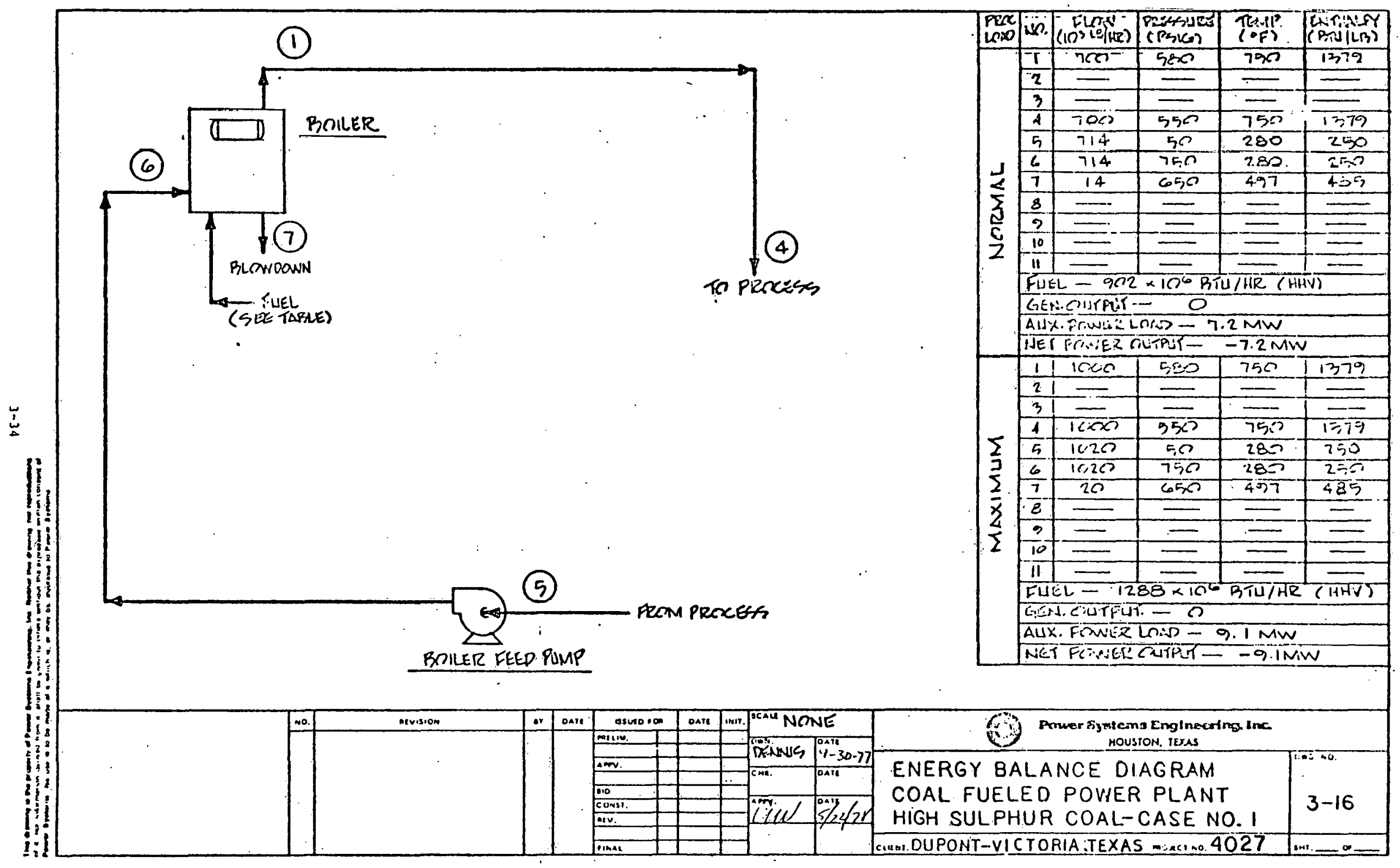




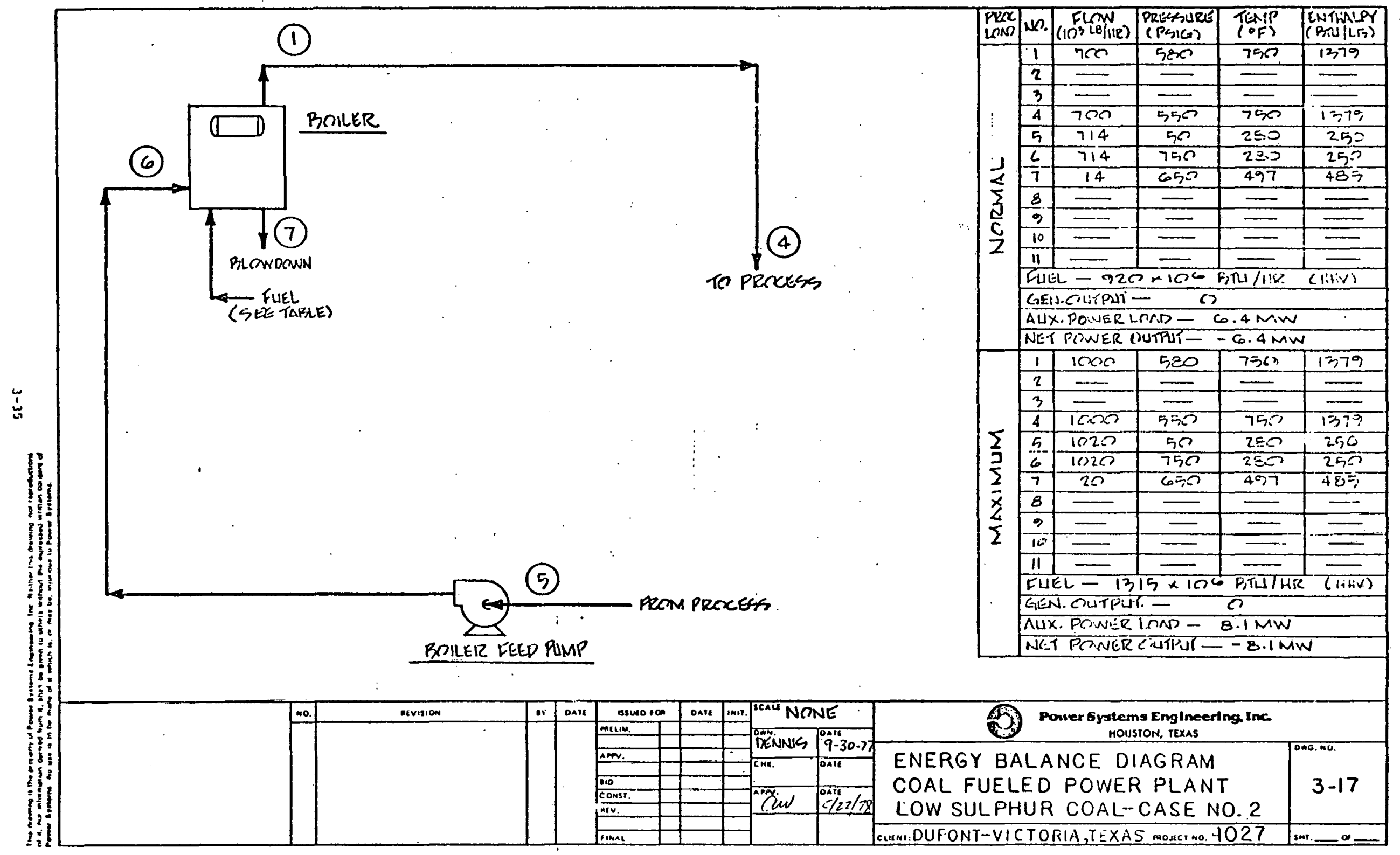




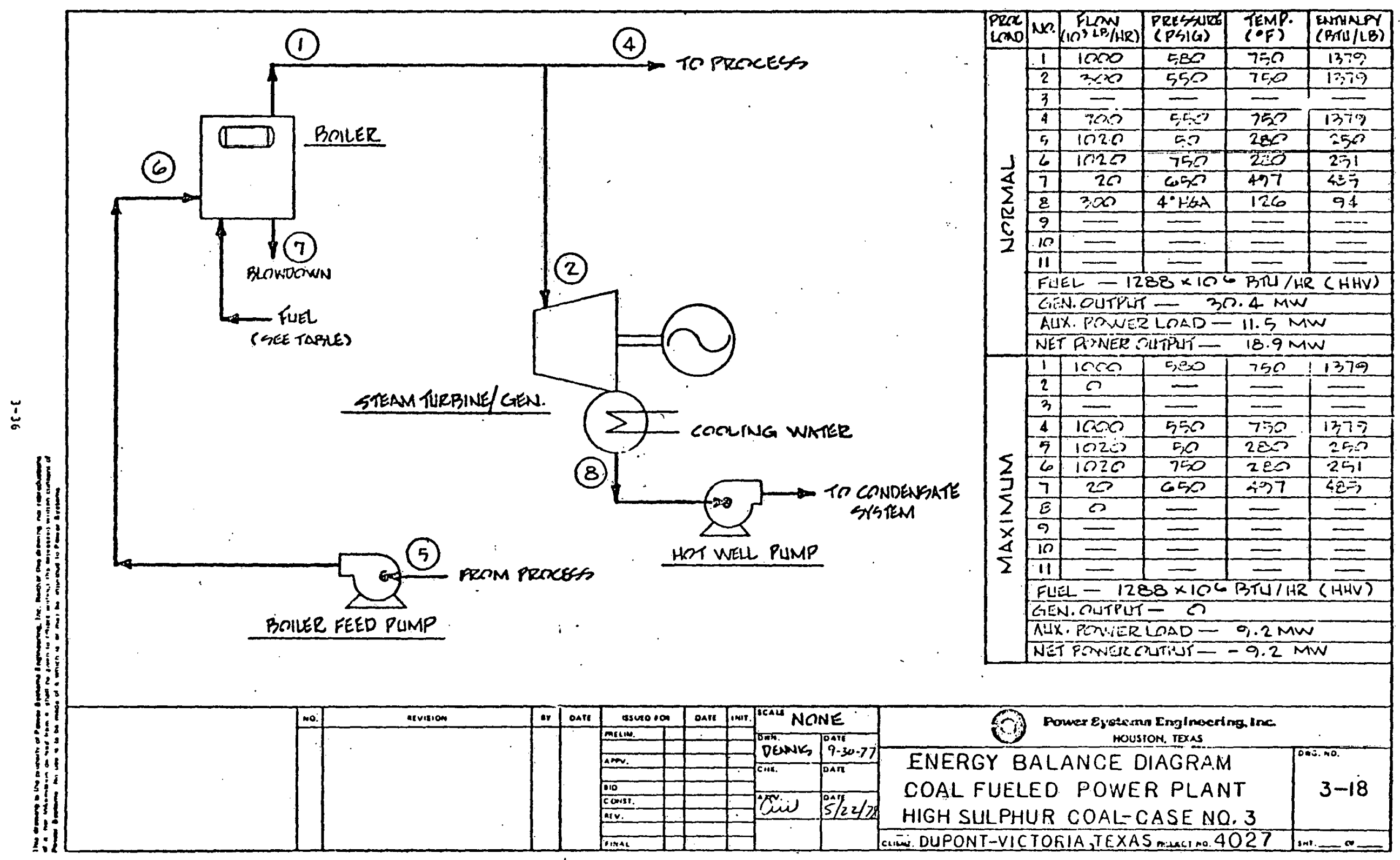




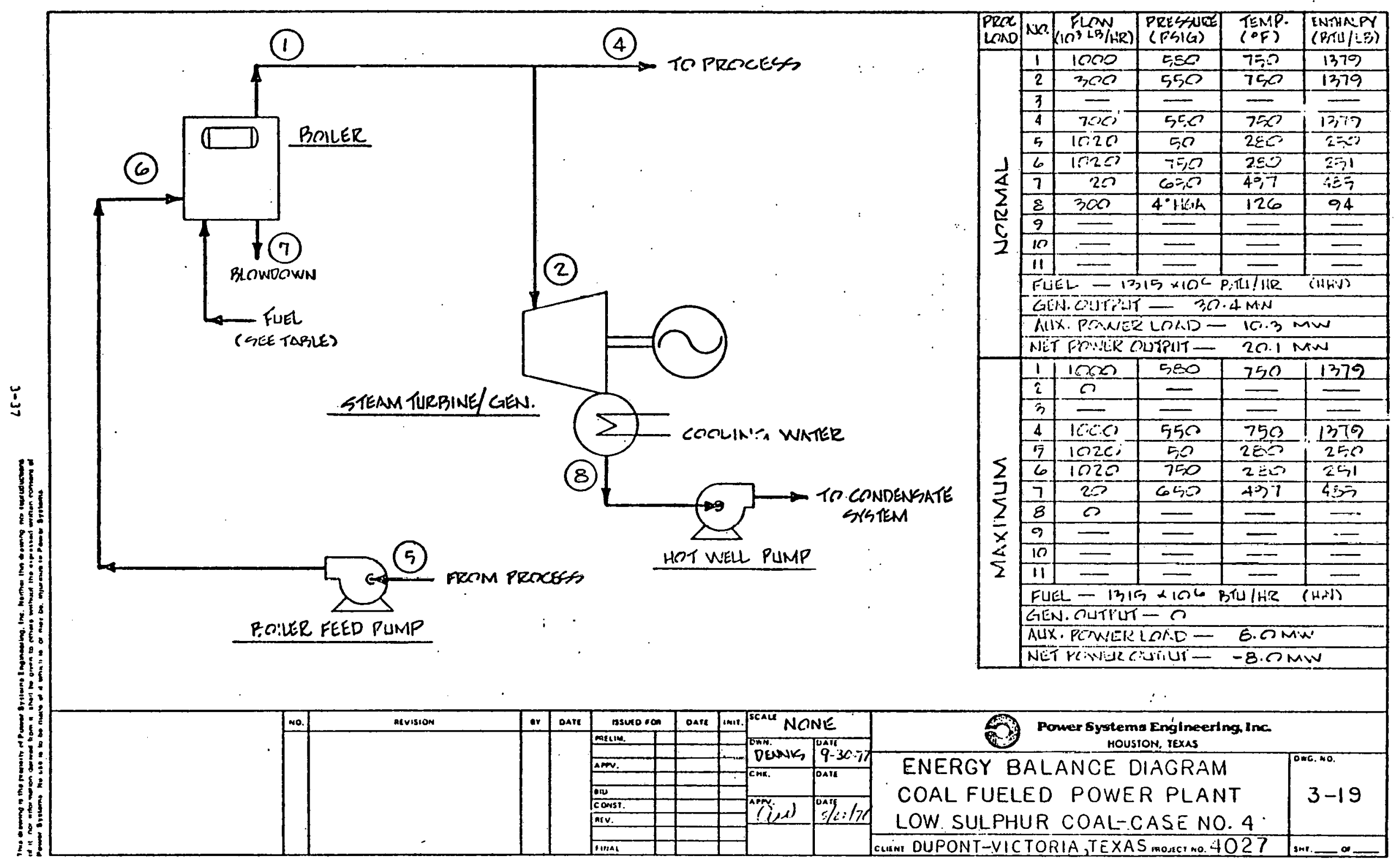




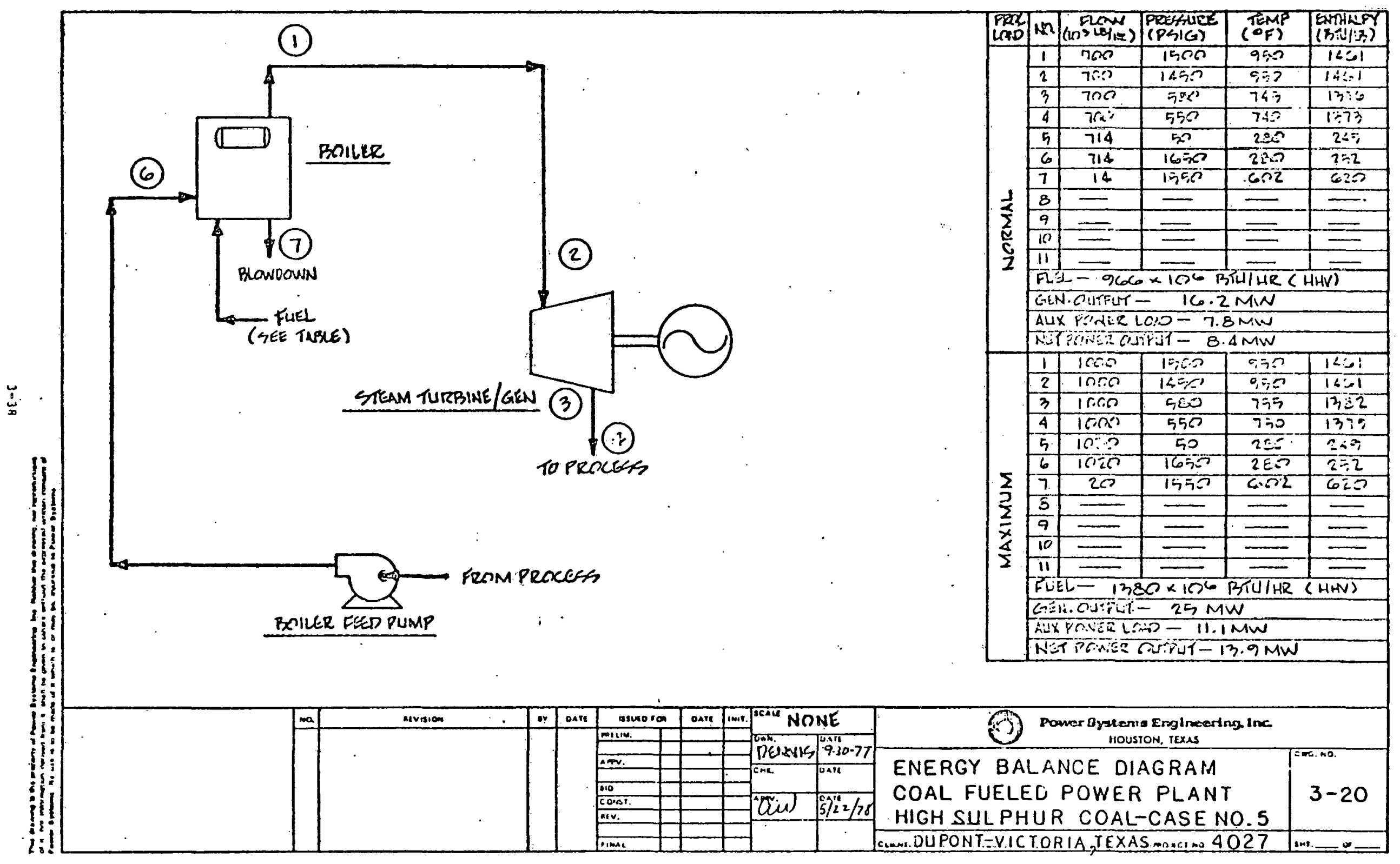




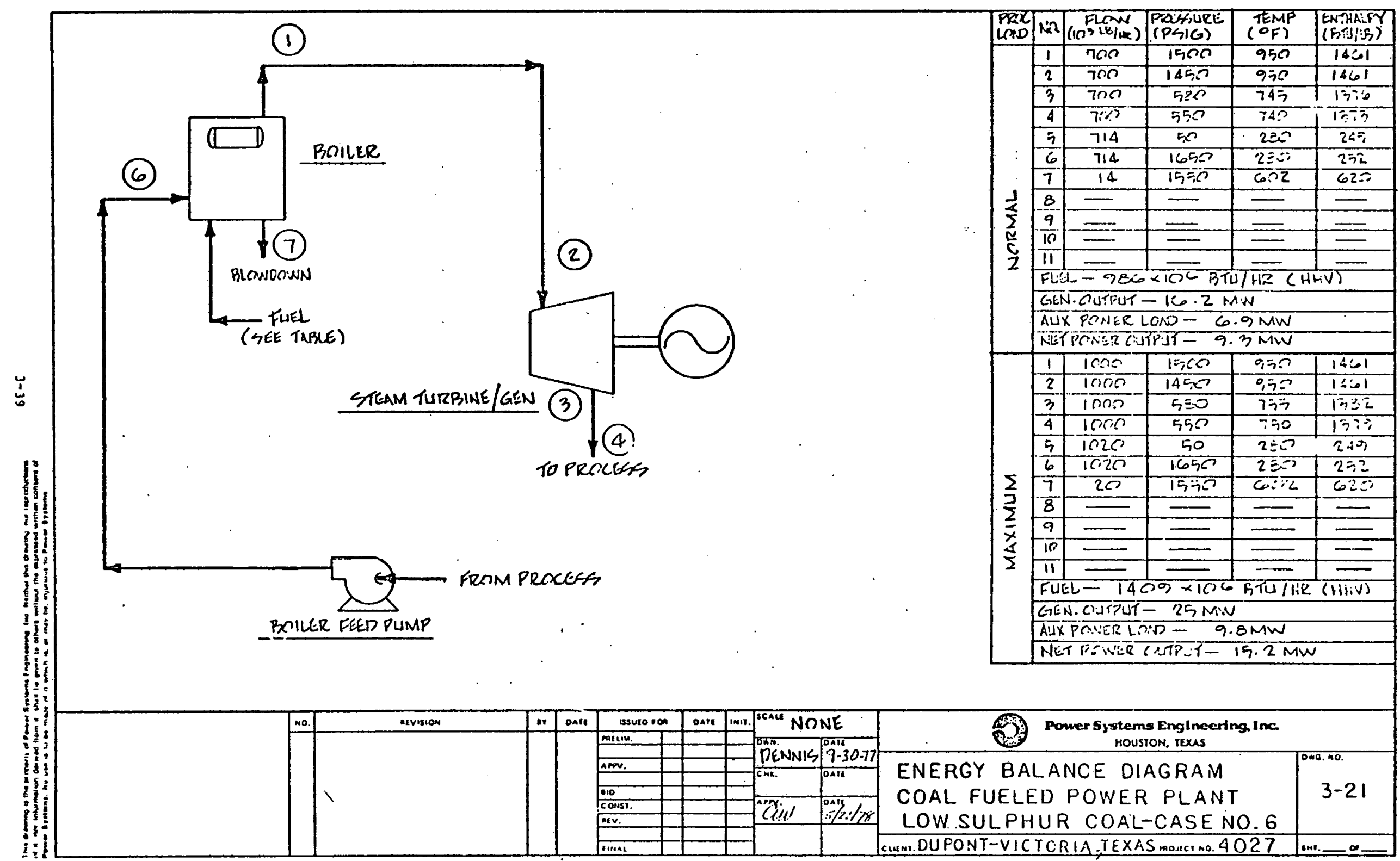




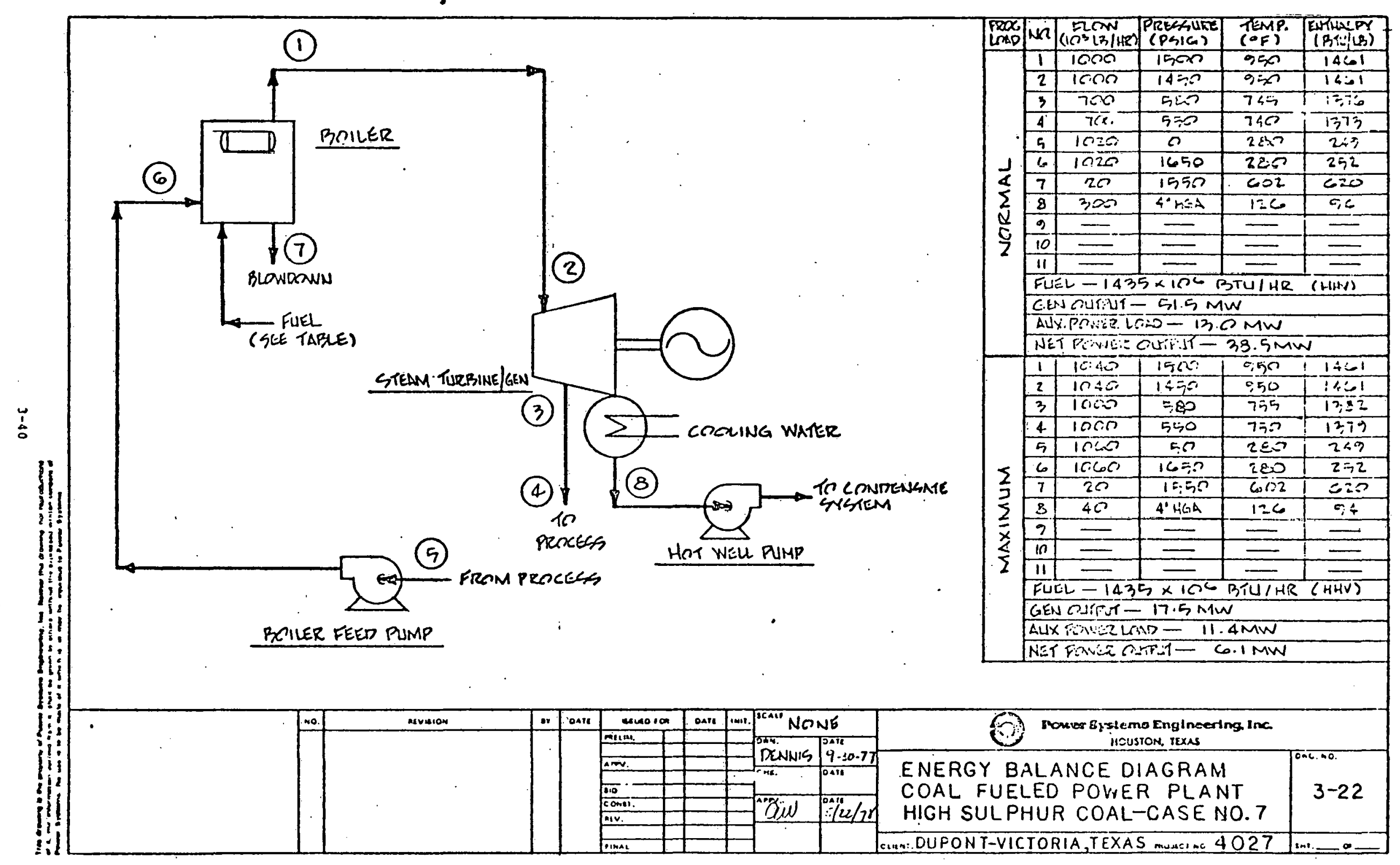




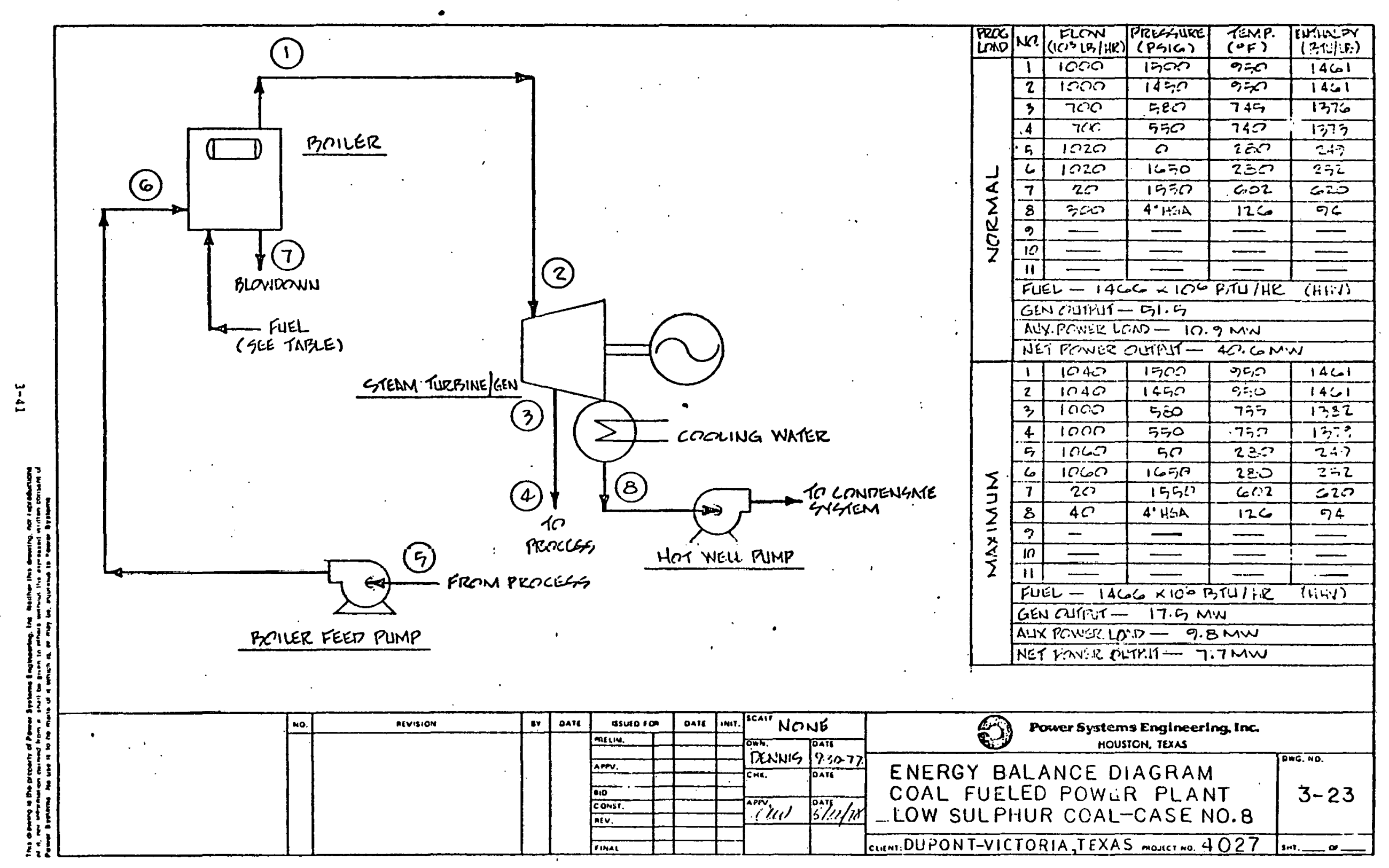




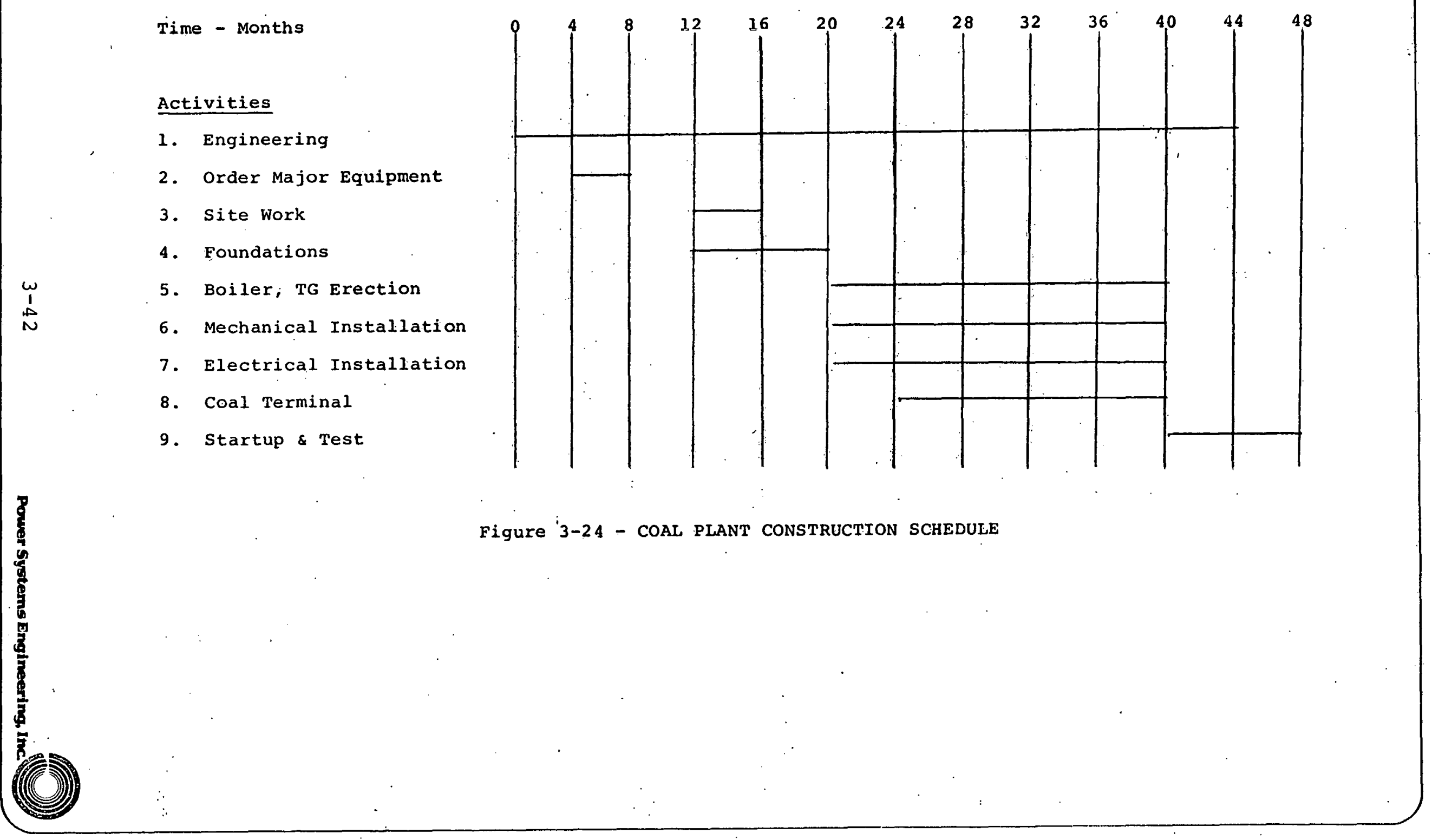


Table 3-1 Reactor Coolant System Parameters

\section{NOMINAL: VALUES}

Design Performance Summary

Power

Steam pressure at SG outlet (at full load)

Steam temperature at SG outlet

Steam flow

Feedwater inlet temperature

Nominal core inlet temperature

Nominal core outlet temperature

Reactor vessel average temperature

RCS flow

\section{Equipment Data/Design Performance Data}

No. of SG modules

RCS total primary volume

Primary water volume

Pressurizer gas volume

Reactor Vessel ID

No. of Control Rod Assemblies

No. of fuel assemblies

RC pump flow (four used)

RC punp head

RC pump expected power, hot

Pressurizer

Overall length

Sheel OD

$\begin{array}{ll}\text { Metric } & \text { English } \\ 365 \mathrm{MWt} & 365 \mathrm{MWt} \\ 5.52 \mathrm{MPa} & 800 \mathrm{psia} \\ 270^{\circ} \mathrm{C} & 518^{\circ} \mathrm{F} \\ 191 \mathrm{~kg} / \mathrm{s} & 1.512 \times 10^{6} \mathrm{lb} / \mathrm{hr} \\ 204^{\circ} \mathrm{C} & 400^{\circ} \mathrm{F} \\ 300^{\circ} \mathrm{C} & 571.6^{\circ} \mathrm{F} \\ 319^{\circ} \mathrm{C} & 606.4^{\circ} \mathrm{F} \\ 309.4^{\circ} \mathrm{C} & 589^{\circ} \mathrm{F} \\ 3289 \mathrm{~kg} / \mathrm{s} & 26.06 \times 10^{6} \mathrm{ib} / \mathrm{hr}\end{array}$

12

12

$106.9 \mathrm{~m}^{3}$

$3775 \mathrm{ft}^{3}$

$99.8 \mathrm{~m}^{3}$

$3525 \mathrm{ft}^{3}$

$7.08 \mathrm{~m}^{3}$

$-250 \mathrm{ft}^{3}$

$3.99 \mathrm{~m}$

$157 \cdot$ in.

17

17

57

57

$1.196 \mathrm{~m}^{3} / \mathrm{s} \quad 18,950 \mathrm{gpm}$

$32.31 \mathrm{~m}$

$106 \mathrm{ft}$

$0.326 \mathrm{MW}$

$437 \mathrm{hp}$

$8.969 \mathrm{~m}$

$2.013 \mathrm{~m}$
$29 \mathrm{ft}, 5.125 \mathrm{in}$.

79.25 in. 


\subsection{ECONOMICS}

\subsection{Economic Philosophy and Methods}

The investments being studied in this report (nuclear and coal process steam generation plants) are mutually exclusive projects. No attempt has been made to compare the study alternatives with the economics of continued utilization of existing. facilities at the Du Pont site. The economic method chosen for the analyses is the "Net Present Value" (NPV) method. This method is commonly used. in the industrial sector for preliminary evaluation of investment alternatives. Cash flows from project go-ahead through 30 years project life are developed which include all major cash flows that result from the implementation of each study project.

Since the nuclear study plants require seven years to construct versus four years for the coal plants, two economic analyses have been prepared. In both analyses nuclear plant construction starts on January 1, 1978. The first analysis considers that the coal plants start construction concurrently with the nuclear plants and thus begin operation three years prior to the nuclear plants. The second set of analyses considers that coal plant construction starts January 1, 1981, and coal plants start operation concurrently with the nuclear plants.

The base date for all economic studies is January 1, 1978, and all cash estimates are reported as of that date. In the analyses, cash flows are reported in current end-of-year dollars having been escalated per schedules suggested by Du Pont or estimated by PSE. The resultant net cash flow from each analysis is discounted at rates of 10,15 and 20 percent to arrive at a range of NPVs for each alternative. These NPVs are then compared to determine the option most attractive from an economic standpoint, namely, the alternative having the highest NPV (or the lowest negative NPV, as is the case with these "expense center" projects).

Should the NPVs of competing projects cross between the 10 and 20 percent discount rates, the choice of alternatives would not be clear and ffurther aralysis should be performed. While such crossings do occur in the results of this study, the NPVs which do cross are so nearly the same over the prescribed range of discount rates, that further analysis would not materially aid in selection of one alternative over another. Thus, the projects are said to be equivalent under the set of assimptions applied to each. Therefore, for the purposes of this study, the NPV method is the sole method employed for economic evaluation of alternative projects. Present value steam costs are presented for each study plant as complementary information.

The following sections summarize the various economic parameters which have been employed in these analyses. The cash flow pro forma statement is described with definitions of each column including mathematical formulae and descriptions of methods. An example of a cash-flow analy'sis is provided in order to illustrate the method. Refer to Figure 4-1. 


\subsubsection{Escalation Schedules}

Since escalation is very real factor in today's economic climate, its effect is accounted for in these studies. Table 4-1 summarizes escalation rates as they have been applied in these analyses. Following are discussions of each of the rates of escalation:

\subsubsection{General Inflation Escalation Rate}

The general inflation escalation rate is applied to the working capital account and to the introductory expense.

\section{4:1.1.2 Construction Labor Escalation Rate}

The construction labor escalation rate is combined with the construction material escalation rate to form a construction composite rate which is then applied to applicable capital expenditures during construction.

\subsubsection{Construction Material Escalation Rate}

The construction material escalation rate is combined with the construction labor escalation rate as in 4.1.1.4. This rate is also combined with the operating labor escalation rate as described in 4.1.1.6.

\subsubsection{Construction Composite Escalation Rate}

The construction composite escalation rate is formed from labor and material escalation rates (4.1.1.2, 4.1.1.3) as follows:

Construction composite rate $=0.35 \mathrm{x}$ construction labor rate $+0.65 \times$ construction material rate.

The construction composite escalation rate is applied to cash flow occurring during, and related to, construction.

\subsubsection{Operating Labor Escalation Rate}

The operations composite escalation rate is combined with the construction materials escalation rate to form an operations composite rate as described in 4.1 .1 .6 .

\subsubsection{Operation Composite Escalation Rate}

The operations composite escalation rate is formed from operating labor and materials rates $(4.1 .1 .3,4.1 .1 .5)$ as follows:

$$
\text { Operations composite rate }=0.4 \mathrm{X} \text {. operating labor rate }
$$
$+0.6 \mathrm{X}$ construction material rate. 


\subsubsection{Operation Composite Escalation Rate - (Continued)}

The operations composite escalation rate is applied to all study plant operating costs subject to escalation except fuel, including the electrical power costs or credits.

\subsubsection{Fuel (Primary) Escalation Rate}

The fuel escalation rate is applied to primary fuel expenses (i.e., coal and nuclear fuel).

\subsubsection{Number 6 Fuel Oil Escalation Rate}

The number 6 fue oil escalation rate is applied to backup operating expense and to the fuel oil cost for superheating nuclear-generated steam where the Fuel-oil fired superheater is employed.

\subsubsection{Federal Income Tax Rate}

The federal income tax rate is applied to adjusted operating expense which is the cost of operations including annual operating expense, fuel expense, depreciation, state sales tax, and introductory expenses. The federal income tax rate is 48 percent. Since these projects generate no revenue, income taxes appear as credits to the project, implying that sufficient corporate tax liability exist to allow taking such a credit.

\subsubsection{Investment Tax Credit}

The investment tax credit is applied to all capitalizable expense during construction. Only land is exempt from the -investment tax credit in this study. The investment tax credit rate is 10 percent.

\subsubsection{State Tax (Ad Valorem) Rate}

The state ad valorem tax is computed as the state rate times the total capital investment and remains a fixed annual expense not subject to escalation for the life of the project operation. The ad valorem tax rate is 1.3 percent.

\subsubsection{State Sales Tax Rate}

The state sales tax rate is applied to an estimate of taxable capital expenditure during construction only. During operating years state sales tax is. included in all expense estimates. State tax is estimated during construction as follows: 
4.1.5 State Sales Tax Rate - (Continued)

State sales $\operatorname{tax}=$ Sales tax rate $\mathrm{X}(0.7 \mathrm{x}$ capital expenditure) (Nuclear Plants)

State sales $\operatorname{tax}=$ Sales tax rate $\mathrm{x}(0.5 \mathrm{x}$ capital expenditure) (Coal Plants)

The sales tax is not applied to land expense. The sales tax rate is 4 percent.

\subsubsection{Insurance Rate}

The insurance rate is applied to the total capital investment and remains a fixed annual expense not subject to escalation for the life of the project operation. The insurance rate is 0.1 percent.

\subsubsection{Construction Labor}

The construction labor hourly rate is $\$ 12.20$, which includes labor, insurance, taxes, construction equipment, small tools and expendables, contractors home office and field overhead, and profit.

\subsubsection{Operations Labor}

The operating staff labor hourly rate is $\$ 12.40$ which includes the base labor rate plus overhead burdens. Table 4-9 presents a breakdown of the operating staff requirements for the nuclear plants. Table 4-12 presents this breakdown for coal plants.

\subsubsection{Plant Availability}

Plant availability is defined as the decimal percerit of a year which the study plant is available for operation at any load within its design capability. The plant availability is 0.8 for nuclear study plants and 0.92 for coal study plants.

\subsubsection{Plant Factor}

Plant factor is defined as the annual energy produced by the plant (reactor or coal plant) divided by the maximum possible energy that could be produced annually by continuous, full load operation.

\subsubsection{Backup Operation}

Backup operating expense is assumed to be the No. 6 fuel oil equivalent of the amount of backup steam flow supplied annually by Du Pont from existing facilities as a result of study plant unavailability, lack of capacity or differences in operating life. The nuclear cases, in which the construction period is three years longer than that for the 


\subsection{Il Backup Operation - (Continued)}

coal cases, are debited with backup operating expenses in the amount of the No. 6 fuel oil equivalent of the Du Pont steam requirement during the last three years of construction for the cases in which coal plants start construction concurrently with nuclear plants. No components of fixed charges or depreciation on existing facilities are included in the backup charge. In addition to backup charges for the rumber 6 fuel oil equivalent of steam, there is a utility electrical power backup charge of $\$ 3.26 / \mathrm{KW} /$ month assessed to those plants which generate in excess of $15 \mathrm{MW}$ gross electrical power. The charge is applied to study plant gross power generation in excess of $15 \mathrm{MW}$. For coal cases 5 and 6 , the electrical power backup charge is calculated for 0.8 times gross power generation less 15 MW since the fraction of time at higher power output is low. Table 4-10 summarizes backup expenses for both number 6 fuel oil. and: for electrical power. These backup expenses are charged to the study plant net of taxes.

\subsubsection{Electrical Power Expense or Credit}

Credit for power generation or expense for auxiliary power generation is computed on the basis of $29.6 \mathrm{mills} / \mathrm{kwhr}$ on January 1, 1978 . The value of electrical power is assumed to escalate at the operations composite rate.

\subsubsection{Working Capital}

A working capital account is established in the cash flow analysis as an entry in the year prior to commercial operation. The only entries during the operating years for working capital are those increases necessary to maintain the capital account in current dollars. The working capital is computed as follows:

\section{Nuclear Plants}

Working Capital $=0.06 \times$ (Annual operating expense + fixed charges) $+0.25 \times$ total annual fuel expense

Doal plants $\begin{aligned} \text { Working Capital }= & 0.06 \mathrm{x} \text { (Annual operating expense }+ \text { fixed charges) } \\ & +30 \text { days limestone }+60 \text { days coal inventory }\end{aligned}$

\subsubsection{Introductory Expense}

The introductory expense includes an estimate of miscellaneous startup expenses such as setting up offices, obtaining startup personnel, and purchasing miscellaneous supplies. The introductory expense column of the cash flow analysis also includes state sales tax during construction. 


\subsubsection{Depreciation}

Qualifying capitalizable expenditures are depreciated over 23 years of operation with the first three years depreciated double-declining balance and the remaining 20 years by the sum-of-year-digits method.

\subsubsection{Cash Flow Pro Forma Statement}

Figure 4-l is a sample cash flow summary. In this section, each column is defined.

4.1.16.1 Column (1) - Capital Expense

Capital expense cash flow is developed from the total capital investment and an estimated schedule of expenditure. The base year estimate is apportioned to the appropriate year and escalated via the construction composite rate $(4.1 .1 .4)$. The land expense is returned in year 30 at its escalated value.

\subsubsection{Column (2) - Backup Operating Expense}

The base year backup operating expense (4.1.10) is escalated according to the number 6 fuel oil escalation rate (4.1.1.8) and entered in each year of operation at its current dollar value, net of taxes (i.e., 52 percent of the escalated backup operating charge is entered).

\subsubsection{Column (3) - Net Change in Working Capital}

The base year working capital estimate (4.1.12) is escalated according to the general inflation rate (4.1.1.1) and entered in the year prior

to commercial operation. The net change in working capital thereafter is only the escalation to maintain constant value in current dollars. Total working capital is returned in the last year of operation.

4.1.16.4 Column (4) - Investment Cash Flow ...

Investment cash flow is the sum of columns (1), (2) and (3).

\subsubsection{Column (5) - Fuel Expense}

The sum of primary fuel (coal or nuclear) and secondary fuel (number 6 fuel for the oil fired superheater where applicable in nuclear plants) expenses is entered in this column after having been escalated according: to the (primary) fuel escalation rate (4.1.1.7) and the number 6 fuel oil escalation rate (4.1.1.8), respectively. For coal plants the base year fuel expense estimate is escalated and entered. For nuclear cases, discrete nuclear cash expenditures (Table 4-2) are escalated and entered. 


\section{1 .16 .6 Column (6) - Operating Expense}

Operating expense includes all annual expenses incurred during the operating life of the project. Power expenses (or credits where applicable) are ircluded as are fixed charges (ad valorem taxes and insurance). The non-fixed portions of the operating expense are escalated according to the operations composite escalation rate (4.1.1.6).

\subsubsection{Column (7) - Total Annual Expense}

Column (7) is the sum of fuel expenses, column (5), and operating expense, column (6).

\subsubsection{Column (8) - Depreciation}

Qualifying capital expenses incurred during construction are depreciated per 4.1 .14 and the resulting depreciation entered in column (8).

\subsubsection{Column (9) - Introductory Expense}

The introductory expense as defined in 4.1 .13 is escalated from its base year value to the year prior to operation and entered in column (9). Also entered in column (9) are state sales tax estimates computed as cescribed in 4.1.5. Thus, the year prior to operation is entered zs the sum of the escalated introductory expense plus the sales tax for that year.

\subsubsection{Column (10) - Adjusted Operating Expense}

This column is the sum of columns (5), (6), (8) and (9) (expenses subject to tax (credit) less depreciation). Income tax (credit) is computed from tis column.

\subsubsection{Column (11) - Federal Income Tax}

Column (11) is computed as column (10) times the federal income tax rate. The federal income tax is taken to be credit if column (I0) shows a cash outflow (negative cash flow).

\subsubsection{Column (12) - Net Operating Expense}

Column (12) is adjusted operating expense, column (10), less federal income tax, column (11) (or increased by federal income tax when the tax is a credit). 


\subsubsection{Column (13) - Investment Tax Credit}

All of the capital expenditures of column (1) qualify for the investment tax credit except the land expense. Column (13) reflects this credit.

\subsubsection{Column (14) - Total Cash Flow}

Column (14) is the sum of net operating expense, column (12); investment tax credit, column (13); and depreciation, column (8). The resultant column (14) is total expense charged to operations reduced jy federal tax (credits).

\section{1 .16 .15 Column (15) - Net Cash Flow}

Column (15) is the sum of investment cash flow, column (4), and total cash flow, column (14). Net cash flow is the actual cash flow, in current dollars, that can be anticipated for the investment under consideration.

\subsubsection{Column (16) - Discounted Cash Flow}

Each year's net cash flow, column (15), is discounted to January I, I 1978, to form column (16). For this study, aiscount rates of 10,15 and 20 percent were assumed.

\subsubsection{Net Present Value}

The sum of the discounted net cash flow values from column (16) is the net present value of the investment. The various study plants are evaluated on the basis of maximum net presen= value (minimum negative present valuel.

\subsubsection{Steam Costs}

The present value steam costs for each of the study cases has been calculated for discount rates of 10, 15, and 20\%. These costs, when escalated at the effective project composite escalation rate, multiplied by Du Pont's total annual Btu requirement then discounted and summed, will yield a present value that is equal to the project NPV at the same discount rate. Expressed mathematically, the steam costs are determined as follows: 


\subsubsection{Steam Costs - (Cotninued)}

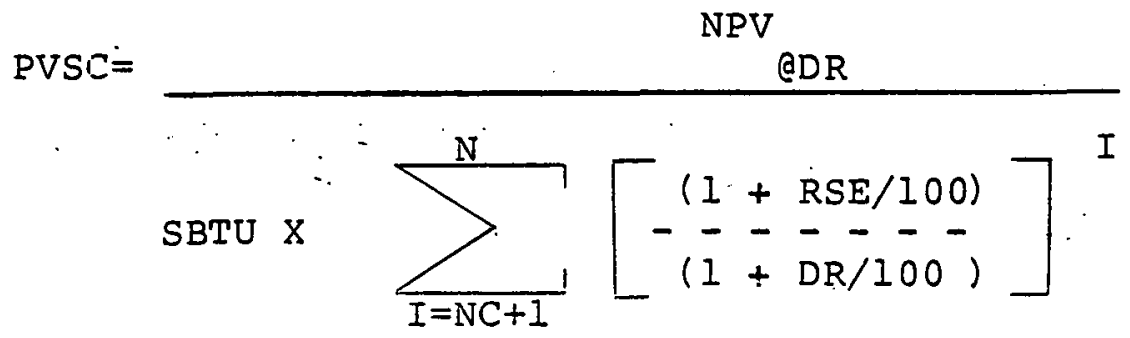

Where: $\begin{array}{ll}\mathrm{N} & =\text { Total project life, years } \\ \text { NC } & =\text { Number of years of construction } \\ \text { I } & =\text { Year index } \\ \text { SBTU } & =\text { Annual steam generation, } 10^{6} \mathrm{Btu} . \\ \text { RSE } & =\text { Rate of steam cost escalation, percent } \\ \text { DR } & =\text { Discount rate, percent } \\ \text { NPV } & =\text { Study plant net present value at DR, } 10^{6} \$ \\ \text { PVSC } & =\text { Present value steam cost, } \$ / 10^{6} \mathrm{Btu}\end{array}$

For all nuclear cases, total project life (N) is 30 years and construction time (NC) is seven years, implying an operating life of 23 years for the nuclear cases. For coal cases in which construction begins concurrently with nuclear plants and operation begins three years prior to nuclear plart operation, the nuclear cases are charged for steam (number 6 fuel oil cost equivalent) during the last three years of construction. In order to make a consistent comparison of steam costs between nuclear and coal plants, the total heat generated as steam must be the same. Therefore, for comparison of steam costs in the cases just described, the last three years of construction for the nuclear plants are considered as operating years by virtue of the fuel oil charge which equalizes the Btu generation with that of the coal plants. Thus the steam costs are calculated for both nuclear and coal plants on the basis of a total life (N) of 30 years and construction period (NC) of four years, or an operating life $(\mathrm{N}-\mathrm{NC})$ of 26 years. This applies only to the calculation of steam costs in the case of concurrent nuclear/coal start construction dates. For the cases of concurrent nuclear/coal oferation start dates, both types of plants are considered to have a 30 year life ard seven years of construction (thus 23 years of operation) for the purposes of steam cost calculations. 


\subsection{Capital Estimates}

\subsubsection{Nuclear Plants}

Total nuclear plant Nth-of-A-Kind (NOAK) capital costs have been estimated by $B \& W, U E \& C$, and PSE. The scope of responsibility for the estimates is shown in Table 4-3. Capital estimates appear in Table 4-4. Many of these costs are based on previous estimates which were revised to reflect the particular situation for the Du Pont site.

The estimates are based on a 40-hour work week and no allowance has been made for construction premium time. Capital cost estimates do not include owner's G\&A costs such as license fees, printing of safety analysis reports, attendance of personnel at hearings, preparation of testimony, legal fees, construction and operation of an information center at plant site, talks by company management and staff members before civic groups, and the G\&A overhead assignable to the project.

In general, NOAK costs are lower than First-of-A-Kind (FOAK) costs due to elimination of nonrepetitive first-time engineering and due to labor learning experience. B\&W NOAK equipment costs are lower due to a $B \& W$ shop labor learning curve and the elimination of firsttime engineering. These improvement factors are based on past $B \& W$ experience with central station plant engineering and equipment.

A reduction in UE\&C equipment scope costs results from field labor learning where there is a carryover of supervisor personnel from one project to another and from nonrepetitive engineering efforts such as preparation of construction procedures, etc.

\section{First-of-A-Kind Cost Estimates}

The nuclear plant costs and the overall economic comparison are based on NOAK costs and thus include no FOAK expenses. For this study it has been assumed that the FOAK costs would be borne by others; possibly EPRI, the U.S. Government, or other organization if deployment of small industrial reactors becomes a national objective.

First-of-a-Kind (FOAK) work is defined as follows:

Those work activities which are nonrepetitive for follow-on units, including nonrepetitive elements of engineering, licensing, and test and evaluation efforts required to develop design parameters, demostrate safety to the regulatory authorities, and verify design adequacy.

Generic activities as defined above include fabrication processes, baseline component and system design, resolution of generic licensing issues, and first-of-kind engineering proof test and evaluation programs. The detailed engineering and construction tasks for the first. unit include, but are not limited to, the following FOAK tasks: 


\subsubsection{Nuclear Plants - (Continued)}

\section{Encineering}

1. Development of reactor plant baseline design (component and system specifications and drawings).

2. Design and stress analyses required to satisfy regulatory agencies.

3. Development of reactor plant checkout, startup, and operating procedures.

4. Support of test and evaluation programs.

5. Architectural and construction design.

6. Developmen $=$ of balance-of-plant system and equipment designs.

7. Development of balance-of-plant checkout, startup, and operating procedures.

\section{Fabrication and Construction}

1. Manufacturing development for welding procedures, special fixtures, and ASME Code cases.

2. Development of special fabrication processes for shop and field construction.

3. Preparation of detailed shop processing and construction schedules.

\section{Licensing}

1. Resolution of generic issues related to the class of reactors:.

2. Determination of necessary supportive environmental monitoring programs.

3. Preparation of generic parts of preliminary and final safety analysis reports.

Inservice and Initial Operational Tests and Inspections

1. Baseline techniques for code in-service inspection.

2. Flow-induced vibration evaluation of reactor internals.

3. Hot functional test programs (field). 


\subsubsection{Nuclear Plants - (Continued)}

Hardware

1. Design and manufacture of special tools and handing equipment for major components.

2. Design and construction of fueling and refueling equipment and special tools.

In addition to the FOAK work items discussed above, certain test and evaluation programs are required to verify design adequacy or to demonstrate the margin of conservatism of the design. The test and evaluation programs also support the licensing process.

Test and Evaluation

1. Steam generator functional performance, secondary side flow distribution, and downcomer performance.

2. Steam generator fouling and chemical cleaning.

3. Upper internals vibration.

4. Control rod guide structure.

5. Fuel assembly prototype detail design and fabrication.

6. Fuel assembly life test.

7. Primary pump prototype.

8. Pressure suppression containment.

9. Reactor coolant temperature sensor.

10. Containment pressure suppression tests (not included as part of the cost estimate provided herein).

The total plant FOAK costs are estimated to be approximately $\$ 25$ million to $\$ 50$ million, including all FOAK costs in the area of engineering, shop and field construction, licensing, in-service and initial operational tests and inspections and hardware design and manufacture. This total plant FOAK estimate assumes all firstof-kind costs are applied to a single program and concept. In reality, many are common to three programs involving integral nuclear steam systems of similar or identical design: The PE-CNSG, the Maritime M-CNSG, and the higher power level CNSS concept. All three program studies and design activities have been supported at least in part by federal agency funding. A construction project involving any one of these programs would give impetus to the others, so some sharing of these first-of-a-kind costs over a period of six to eight years between programs can be considered. In this respect, first-ofa-kind government support of these programs should be especially cost- 


\subsubsection{Nuclear Plants - (Continued)}

effective. If FOAK costs could be shared between programs, the above estimated range of FOAK costs for a given program such as PE-CNSG could be reduced correspondingly.

The FOAK cost estimates discussed above are not based on an extensive investigation in this study but rather are based on work previously done in the Phase I study and in M-CNSG program activities. If an industrial process energy user should decide to proceed further with this study, the balance-of-plant FOAK costs should be determined in more detail.

The previous estimates do not include consideration of government legislation to provide nuclear accident liability insurance similar to Price-Anderson legislation. This may be required to cover industrial organizations as an incentive to establish nuclear plants for initial industrial installations. The estimates also exclude the cost of longer first-time construction schedules and resultant cost increases for pioneer plants.

\subsubsection{Coal Plants}

Total coal plant costs have been estimated by PSE. Capital estimates are presented in Table 4-5. The estimates represent costs for the complete coal plant including all coal handling systems, scrubbing systems (where required), ash and sludge handling systems, and auxiliaries required under the scope of this study.

Specifications were written for major equipment items and submitted to vendors who returned budget quotations. The items estimated in this manner are as follows:

Steam Generator (Boiler)
Flue Gas Desulfurization System
Electrostatic Precipitator System
Coal Stacker/Reclaimer System
Rail Car Roller/Positioner System
Ash Handing System
Turbine-Generator

The costs of auxiliary systems not obtained through quotation were estimated by PSE as were engineering and installation not provided by Du Pont including site preparation.

The estimates are based on a 40-hour work week and no allowance has been made for construction premium time. The capital estimates do not include Du Pont $G \& A$ costs, license fees, environmental impact study costs or other incidental expenses that would be assignable to internal Du Pont overhead. 


\subsection{Fuel Economics}

\subsubsection{Nuclear Fuel}

The nuclear fuel costs used in this study are based on a typical nuclear fuel "cycle" such as that depicted in Figure 4-2. The cycle includes all of the major processes that occur from the mining of the uranium ore to the final disposal of the fuel. The criteria for determining the cost of each process are listed in Table 4-6. These criteria were supplied by Jak Ridge National Laboratory and represent 1985 costs in terms of January 1, 1978 dollars.

Fuel cycle costs were generated as discrete cash flows for input to the economic analysis computer program. These cash flows are given in Table 4-2. Nuclear fuel cycle costs were assumed to escalate at a rate of 6 percent per year.

Each process in the fuel cycle is briefly described below including its contribution to the total fuel cycle cost. The total fuel cycle cost for this study ranges from 49 to $53 \% / 105 \mathrm{Btu}$ for the reprocessing fuel cycle to 60 to $66 \% / 106 \mathrm{Btu}$ for the non-reprocessing fuel cycle.

$\mathrm{U}_{3} \mathrm{O}_{8}$

- The uranium ore is found, mined, and milled to produce $\mathrm{U}_{3} \mathrm{O}_{8}$ yellowcake. This is about 46 to 518 of the total fuel cycle cost, depending on the exact cycle..

Conversion - The yellowcake $\left(\mathrm{U}_{3} \mathrm{O}_{8}\right)$ is converted to a gas, $\mathrm{UF}_{6}$. This is approximately 18 of the total fuel cycle cost.

Enrichment - The UF6 is currently fed into the U. S. Government gaseous diffusion enrichment facilities. (Consideration is being given to the construction of privately owned enriching facilities.) Here, the ratio (emrichment) of U-23.5 to U-238 atoms is increased from that naturally occurring $(0.00711)$ to between 0.02 and 0.04 . The customer is charged for the number of separative work units (SWUs) used. The number of SWUs is proportional to the total amount of enriched uranium obtained and also to the final uranium enrichment. This part of the fuel cycle typically is about 28 to 338 of the total fuel cycle cost.

Conversion \& Fabrication
The enriched UF6 is then converted to powdered $\mathrm{UO}_{2}$. The powdered $\mathrm{UO}_{2}$ is formed into pellets and loaded into fuel rods, which are then arranged into fuel assemblies. This process is about 13 to $21 \%$ of the total fuel cycle cost. 


\subsubsection{Nuclear Fuel - (Continued)}

Spent Fuel - A Eter the fuel assemblies are "burned" in the reactor Shipping \& to produce energy, they are unloaded from the reactor Disposal and are allowed to cool for several, months before shipping. The fuel is now either reprocessed or permanently stored without reprocessing. In reprocessing, the fuel rods are disassembled, the fuel pellets are dissolved, and the remaining uranium and valuable isotopes are recovered, while the rest is disposed of in a radioactive waste storage facility. The recovery of the uranium and valuable isotopes is a credit which helps reduce the overall fuel cycle costs. These credits have been taken in the $\mathrm{U}_{3} \mathrm{O}_{8}$ and enrichment cost elements. The reprocessing and shipping costs are approximately $17 \%$ of the total fuel cycle costs. This is nearly offset by the plutonium credit, which has been specified by the ORNL criteria (Table 4-6). Permanent storage of tine fuel assemblies in the nonreprocessing case is about 7 of the total fuel cycle cost.

\section{3 .2 Coal}

In this study, it is assumed that for a project of this size the industrial user would purchase coal under long term contract from a mine in lieu of purchasine reserves or participating in a mining operation. It is also assumed that the user would contract for unittrain delivery of the cral from the mine to the plant site. The estimated delivered cost of high-sulfur Illinois coal $(10,900 \mathrm{Btu} / \mathrm{lb})$ and low-sulfur Wyoming coal (8250 Btu/lb) are presented in Table 4-7. on the basis of a 100-car, 10,000 ton capacity unit train and 1575 tons per day of Illinois coal, one unit train every six days will be required. For Wyoming coal at 2080 tons per day, one unit train every five days will be required.

High-sulfur coal from Illinois was assumed, although the range of delivered prices would include high-sulfur coal delivered from anywhere within the same approximate radius of Victoria. There have been no long-term contracts for Illinois coal disclosed as yet for plants in Texas, and this fact makes it difficult to estimate accurately the delivered price of high-sulfur coal.

Conversely, there is experience with wyoming low-sulfur coal in Texas, and the $\$ 1.35 / 10^{6} \mathrm{Btu}$ price falls within the range for which contracts are being made. In order that high-sulfur coal remain competitive, it is reasonable to assume that its delivered price will remain no greater than, and generally less than that of lowsulfur coals. The user's actual contract negotiations will finally determine either high- or low-sulfur coal prices but. it is believed that the $\$ 1.20 / 10^{6} \mathrm{Btu}$ (high-sulfur) and $\$ 1.35 / 10^{6} \mathrm{Btu}$ (low-sulfur) price estimates are feasible. 


\subsubsection{Coal - (Continued)}

As is the case with current delivered coal prices, future price determinations are quite difficult to project accurately. It has been assumed that the price of coal will escalate at a rate of 6 percent, a rate slightly higher than the general inflation rate. As discussed in section 4.6 .3 , the effects of different escalation rates for coal and nuclear fuels have been determined and are seen to be quite significant, with the nuclear cycle be less sensitive.

Barge transportation of coal has not been considered in this study. Savings in transportation costs could be realized through the use of barge transportation over part or all of the route from the mine to the site. Should coal come into widespread use in Texas and other locations potentially serviceable by barge, river traffic will increase significantly and could ultimately become saturated. While rail transportation facilities are expected to also undergo periods of shortages, ultimately the rail capacity can be increased to accomnodate the demand. Disregarding these limitations, the exclusive use of rail transportation for this study has introduced a degree of conservatism into the results which are affected by fuel price.

\subsubsection{Number 6 Fuel Oil}

Number 6 fuel oil is used for superheating nuclear-generated steam in a fired superheater for nuclear cases 1,2 and 5 . It is also used as fuel for operating backup (existing) steam generation facilities for all coal and nuclear study plants. The base price for number 6 fuel oil has been taken as $\$ 2.60 / 106_{\mathrm{Btu}}$ for the purpose of this study. The escalation of fuel oil price is assumed to be at a rate of 6 percent per year.

\subsection{Operating Economics}

\subsubsection{Operating Load and Backup Expense}

The operating load is determined from the specified steam demand schedule supplied by Du Pont. The levelized annual steam demand is calculated as follows:

\begin{tabular}{cc} 
REQUIRED & PERCENT \\
STEAM FLOW & OF TIME \\
LB/HR & REQUIRED \\
\hline & \\
600,000 & 20 \\
700,000 & 49 \\
810,000 & 23 \\
900,000 & 6 \\
$1,000,000$ & 2
\end{tabular}

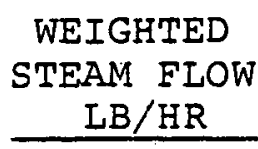

120,000

343,000

186,000

54,000

20,000

LEVELIZED ANNUAL STEAM. FLOW: $723,0000 \mathrm{LB} / \mathrm{HR}$ 


\subsection{Operating Load and Backup Expense - (Continued)}

Thus, to meet the process steam flow requirement, study plants are required to provide process steam at a levelized rate of 723,000 lb/hr, with the capability of meeting the schedule outlined above. In computing the annual operating expenses, each study plant was operated so as to satisfy the levelized steam flow requirement, subject to its plant availability. To obtain steam-load-related annual expense (fuel, backup operation, power credit or expense, etc.) the expenses first were determined for level annual operation at $723,000 \mathrm{lb} / \mathrm{hr}$ steam load and then adjusted by the appropriate plant availability. In so doing, constant operating efficiencies and linear operating characteristics are implied.

Backup operating expense is calculated as follows:

Levelized Backup Steam Requirement $=723,000$ lb/hr $\times$ (1-Availability) Annual Backup Btu Requirement

$=$ Levelized Backup Steam Requirement $\times 8760 \mathrm{Hr} / \mathrm{Yr} \times$ B.tu./Ib. Steam

Annual Backup Dperating Expense

= Annual Backup Steam Requirement $x$ cost of No. 6 Fuel 0il/106 Btu $\div$ Boiler efficiency (86\%)

For nuclear cases 1 and 3 , where the design capacity is only 810,000 lb/hr steam flow, an additional penalty for backup operating expense has been included.

For concurrent nuclear/coal construction start date cases, in which the nuclear plants require three years longer to construct than do the coal plants, the lifetime steam output of these nuclear cases is forced to be equal to that of the coal cases through a backup charge in years 5, 6 and 7 during nuclear construction. These backup charges are the No.6 fuel oil equivalent of Du Pont's steam requirement during each of those three years. See section 4.1 .10 for a complete description of backup operating expenses.

\subsubsection{Plant Availability}

\subsubsection{Nuclear Plants}

The cumulative availability of Babcock \& Wilcox"s seven large operating nuclear steam systems (NSS) through June 30,1977 , ranges from 0.61 for the lowest to 0.92 for the highest, with a mean of 0.74 over the entire period of their commercial operation. Note that this refers only to nuclear system availability as opposed to plant availability. Ongoing work by B\&W's Nuclear Power Generation Division to improve product relialility and thus minimize maintenance downtime has enabled $B \& W$ nuclear units to achieve this excellent availability record to date, and the data trend has been towards more reliable operation as operations continue. 


\subsubsection{Nuclear Plants - (Continued)}

Through an extensive study of nuclear plant reliability, $B \& W$ has identified the nuclear system components that have contributed most highly to plant outages (low reliability). Such equipment as reactor coolant pump seals, control rod drives, pressurizer spray valves, and surveillance specimen holder tubes have contributed significantly to the NSS unavailability. Programs have been implemented within $B \& W$ that have either corrected the problem or that have identified potential corrections. This ongoing product reliability improvement program has as its objective an increase in total plant availability.

The equipment improvement program for the large B\&W NSS plants has direct impact on increasing the PE-CNSG availability by feeding forward pertinent design improvement during the design stages of the PE-CNSG. Some design improvement modifications on NSS plant equipment, such as control rod drives, have direct application to the PS-CNSG, as these drives (in shortened form) are used on the PE-CNSG. Some NSS equipment problems, such as seals on primary coolant pumps, do not apply to the PE-CNSG, as it uses glandless wet stator machines with no mechanical seals between the pump and motor.

Considering the current availability of B\&W operating NSS's and the potential improvements which should occur by the time of PE-CNSG. operation, a plant availability of 0.80 was chosen for the PE-CNSG nuclear fuel cycle studies. A 12-month refueling period was chosen. Availability is defined in section 4.1.9. Plant factor is defined in section 4.1.10. For nuclear cases 4 and 5 , a reactor plart factor of 0.80 was assumed. To achieve this plant factor, the NSS availability must of course be greater than 0.80. Since most process plants operate near rated load most of the time, the availability required to achieve a 0.80 plant factor would probably have to be only slightly above 0.80. This is considered to be achievable, as previously discussed.

At 0.80 plant availability the system is available for design-condition operation 292 days per year and unavailable 73 days per year due to annual maintenance, refueling, or unscheduled outages.

\subsubsection{Coal Plants}

Industrial coal plants, with their around-the-clock maintenance attention, are capable of achieving quite high plant availability factors. For this study, a plant availability of 0.92 has been selected. Translated, this factor means that the coal plant will be available to deliver design steam flow or operate at any load $92 \%$ of the time, or 336 days per year. The remaining 29 days per year the coal plant will be unavailable either because of scheduled maintenance or because of unanticipated operating difficulties. 


\subsubsection{Annual Operating Expense}

\subsubsection{Nuclear Plants}

Nuclear plant annual operating costs (less fuel) have been estimated by ORNL and PSE and are reported in Table 4-8. Staff requirements for plant operations are tabulated in Table 4-9. Costs for operating the superheater and turbine - generator are reflected in additional staff for the nuclear cases which utilize an oil-fired superheater and/or have electrical generation capability. .

Fuel costs for nuclear cases 1,2 and 5 include the cost of number 6 fuel oil for a fired process steam superheater. For cases 3 and 4 which have no superheater, only the nuclear fuel component applies.

Because of the batch method of fueling the nuclear reactor, nuclear fuel costs are reported as discreté cash flow expenses for each year from first Eueling through the life of the project. These nuclear fuel cash flow expenses are summarized in Table 4-2 for each fuel cycle considered in these analyses. The fuel expenses are net expenses and include the cost of new fuel and credits for spent fuel where suci credits apply (reprocessing cycles). For nonreprocessing cycles, the spent fuel is "thrown away" and no salvage value is assigned. Cosis for spent fuel storage are included.

For plants including the number 6 fuel-oil fired superheater, the number 6 fuel oil expense is added to the nuclear cash flow in each year of operation (after escalation of both fuel oil and nuclear fuel expenses). Number 6 fuel oil expenses are summarized in Table 4-10, including the cost of oil required for superheating and for backup operation. (Backup operation is not considered as an annual operating expense per se. See section 4.1 for the treatment of all cash flow components.)

\subsubsection{Coal Plants}

Coal plant annual operating cost estimates are reported in Table 4-1l. Staff requirements for plant operation are tabulated in Table 4-12. Adjustments in staff have been made according to requirements of plant configuration.

Limestone for $\mathrm{SO}_{\mathrm{x}}$ scrubbing is estimated at $\$ 7.00$ per ton. Sludge and/or ash disposal has been estimated to cost $\$ 0.05 / 106 \mathrm{Btu}$ of high-sulfur coal fired and $\$ 0.035 / 10^{6} \mathrm{Btu}$ of low sulfur coal fired.

\subsection{Comparative Economics}

The net present value (NPV) and present value steam costs of the five nuclear plants and eight coal plants were determined for discount rates of 10,15, and $20^{\circ}$ percent as outlined in 4.1 . Figures $4-3$ through 4-27. summarize the results. The assumption for coal plant construction start date is noted on the curves. 


\subsection{Comparative Economics - (Continued)}

Economic results by plant type (coal, nuclear) are discussed in the following section, followed by a discussion of the results of the coal vs. nuclear economic comparisons.

\subsubsection{Nuclear Plants}

\subsubsection{Plants Satisfying Process Steam Temperature Requirements}

Nuclear plant cases 1, 2, and 5 satisfy the required steam conditions of $750 \mathrm{~F}$ and $550 \mathrm{psig}$ delivered to process. Case 1 is designed to deliver a maximum of $810,000 \mathrm{lb} / \mathrm{hr}$ of steam to process, while cases 2 and 5 are designed deliver the specified $1,000,000 \mathrm{lb} / \mathrm{hr}$ peak steam flow demand. For economic evaluation, the nuclear plant for case 1 is assumed to be supplemented by a number 6 oil-fired peaking unit in order that the total process steam output from Case 1 is identical to that for Cases 2 and 5 . The supplemental steam is charged at the fuel oil equivalent value of the case l steam deficit, net of taxes. (Table 4-10). Case 5 is designed with condensing cycle electrical power generation capability via a turbine-generator inserted into the secondary steam loop which generates a net 26.1 MW power for use by Du Pont. Each of these three plants has been analyzed for operation per section 4.1. The results of the economic analysis are presented in Figures 4-3 through 4-6.

Case 5 has the highest NPV (the lowest negative NPV) for discount rates under 20 percent and is the economic choice for that range of discount rates. The results for case 5 show that the addition of electrical generating capacity reduces the cost of process steam relative to the steam-only case 2 .

It is evident by comparing cases 1 and 2 that the capital savings realized from the reduced steam capacity and consequently lower superheating cost in case 1 is offset by the increased backup operating expense required. The relative attractiveness of cases 1,2 , and 5 was not influenced by changes in the coal-fired plant schedule (Figures $4-3$ and $4-4$ versus Figures $4-5$ and $4-6$ ) or by associated changes in oil requirements. It can be conciuded that the $1,000,000$ lb/hr steam capacity chosen for the case 5 design is appropriate. and is the proper economic choice for discount rates under 20 percent.

\subsubsection{Benchmark Plants (Saturated Steam)}

Cases 3 and 4 were designed with no facilities for superheating the steam. Case 3 is identical to case 1 with the single exception of steam superheat capability and thus provides a benchmark determination of the economic effect of the superheat capability for an average steam flow rate of $723,000 \mathrm{lb} / \mathrm{hr}$. Figures 4-7 through 4-10 present the results of the economic study of the effect of superheating. In each case the addition of superheat is seen to decrease NPV approximately $\$ 20,000,000$ at a discount rate of 10 percent and approximately $\$ 5,500,000$ at 20 percent. Steam costs are increased 6 to 12 percent by the addition of oil-fired superheating. 


\subsubsection{Benchmark Plants (Saturated Steam) - (Continued)}

In order to gain an appreciation of the penalty incurred by operating a saturated-steam only PE-CNSG at less than its design capability, a further hypothetical comparison was developed. For this comparison, case 4, it was assumed that Du Pont has a constant annual saturated steam demand of: (a) $723,0001 \mathrm{~b} / \mathrm{hr}$ and (b) $1,288,0001 \mathrm{~b} / \mathrm{hr}$.

Assuming that only the steam demand varied while other assumptions remained the same, present value steam costs were determined for both $1,288,000$ and $723,0001 \mathrm{~b} / \mathrm{hr}$ steam flows. The results of this comparisor are presented in Figure 4-11. The unit cost for saturated steam is seen to be reduced approximately 208 as a result of using the PE-CNSG at its full capacity.

\subsubsection{Coal Plants}

Each of the coal plant designs satisfies Du Pont's process steam requirements, including flow, pressure, and temperature. Cases 1, 3, 5 , and 7 are high sulfur-coal-fired plants with flue gas sulfur scrubbing; cases $2,4,6$, and 8 are low-sulfur-coal-fired plants without scrubbing facilities. See section 3.0 for technical descriptions of these plants. Cases 1 and 2 provide steam only and include no electrical power generation capability. The remaining plant designs include various schemes for power generation by means of backpressure, condensing, or a combination extraction-condensing turbine generator.

Figures 4-12 through 4-15 present the results of the economic evaluation of the high-sulfur-coal-fired plants. Among these plant concepts, the case 7 coal plant is the economic choice over the range of discount rates studied.

Figures 4-16 through 4-19 present the results of the economic evaluation of the low-sulfur coal-fired plants. The Case 6 plant is seen. to be the economic choice in Figures 4-16 and 4-17, while the case 6 and case 8 plants are economically equivalent in Figures 4-18 and 4-19. Deferring the start of coal-fired plant construction from 1978 to 1981 does not alter the relative economic attractiveness of the various plant concepts studied.

The optimum high- and low-sulfur coal-fired plants are compared in Figures 4-20. timrough 4-23. Were low-sulfur coal firing without flue gas scrubbing to be allowed, the low-sulfur plants would be the economic choice. However, it is a virtual certainty that all new coal fired plants will be required to scrub flue gas. The addition of flue gas scrubiing to the low-sulfur plants would decrease their NP.V below that of the high-sulfur plant, case 7. Therefore the case 7 high-sulfur coal fired plant is the economic choice for comparison with case 5 nuclear plant. 


\subsubsection{Economic Comparison of Optimum Coal and Nuclear Plants}

The case 5 nuclear plant and case 7 coal plant are compared in Figures 4-24 through 4-27. At the present =ime, there is no nuclear fuel reprocessing allowed in the United States. However, the possibility that fuel reprocessing may become feasible in the future cannot be ruled out entirely. The results of the Case 5 nuclear plant economics are presented assuming both reprocessing and non-reprocessing fuel cycles. Because of the low sensitivity of nuclear plant economics to fuel costs, the impact of non-reprocessing is quite small. The non-reprocessing fuel cycle increases the fuel cost over that of the reprocessing fuel cycle by approximately 10 percent. The case 7 high-sulfur coal-fired plant is presented assuming coal prices of $\$ 1.20, \$ 1.40$, and $\$ 1.60 / 10^{6} \mathrm{Btu}$. At a discount rate of 15 percent, the coal plant is the economic equivalent $0 \equiv$ the nuclear plant (Base case) at a coal price between $\$ 2.00$ and $\$ 2.20 / 10^{6} \mathrm{Btu}$ for the concurrent nuclear/coal construction start date assumption (Figure 4-24. and $4-25)$ and between $\$ 2.40$ and $\$ 2.50 / 10^{6}$ Btu for the concurrent nuclear/coal operation start date assumption (Figures 4-26 and 4-27). To illustrate the effect of plant availability, the NPV of the coal plant firing $\$ 1.20 / 10^{6} \mathrm{Btu}$ coal is shown for an availability of 0.85 .

Refer to section 4.1 .17 and note that the present value steam cost is a function of net present value, annual steam Btu production and a - discount factor (same value for all coal and nuclear cases for the same discount rate and escalation rate). In the case of concurrent construction, implying 26 years of operation, this discount factor is calculated over the range 5 to 30 years. For the concurrent operation assumption, implying 23 years of operation, the discount factor is calculated over the range 8 to 30 years, thus lowering the factor and tending to increase the present value steam cost.

The higher present value steam cost for the nuclear case as shown in Figure 4-27 is the result of the discount factor decreasing at a rate faster than that of the improvement of nuclear plant net present value. The approximately equal coal present value stean cost in both Figures 4-24 and $4-27$ is the result of the coal plant net present value and the discount factor decreasing at the same rate.

\section{6. .NPV Sensitivity to Variations in Econonic Parameters}

Seven economic variables have significant inpact on the NPV of the investments being considered in this study:

- Capital Investment

-. Primary Fuel Cost (Coal, Nuclear Fuel)

- Primary Fuel Cost Escalation

-. Secondary Fuel (Number 6 Fuel 0 1 )

- Operating Cost (Less Fuel)

.. Power Cost/(Credit)

-. Availability 


\subsection{NPV Sensitivity To Variations in Economic Parameters-(Continued)}

In order to evaluate the sensitivity of NPV to these parameters, coal case 7 and ruclear case 5 were analyzed for a range of variations in the parameters. Both cases are for the concurrent construction start date, January 1, 1978. The results of this sensitivity study are presented in Table $4-13$ and discussed in the following section.

\subsubsection{NPV Sensitivity to Variation in Capital Investment}

Both plants exhibit approximately the same sensitivity to capital investment costs. At low discount rates the nuclear plants are slightly more sensitive due to the capital intensiveness of the nuclear plant.

\subsubsection{NPV Sensitivity to Primary Fuel Cost}

The annual expense for nuclear fuel is significantly less than for coal. This fact is apparent in the sensitivity of nuclear plant NPV to primary fuel cost variations, which is approximately one-third to one-fourth of the coal plant sensitivity to coal price.

4.6.3 NPV Sensitivity to Variations in Primary Fuel Cost Escalation Rate

As was observed for primary fuel cost, the effect on NPV of varying fuel cost escalation rate is significantly greater for the coal plant. The amplification of sensitivity by a factor of more than four is, once again, related to the relative prices of coal fuel and nuclear fuel.

\subsubsection{NPV Sensitivity to Variations in Number 6. Fuel Oil Costs}

Because the nuclear plant uses number 6 fuel oil for superheating steam as well as for a backup operating fuel, its NPV is more sensitive to variations in fuel oil cost. Note that the nuclear plants exhibit a higher sensitivity to number 6 fuel oil cost than to the primary nuclear fuel costs.

\subsubsection{NPV Sensitivity to Variations in Number 6 Fuel oil Cost Escalation Rate}

For the reason stated in 4.6.4, the nuclear plant is twice as sensitive to fuel oil price escalations as is the coal plant. 
4.6 NPV Sensitivity to Variations in Economic Parameters - (Continued)

\subsubsection{NPV Sensitivity to Annual Operating Costs (Less Primary Fuel)}

The difference in sensitivity to nonprimary fuel operating costs between nuclear and coal plants reflects the higher coal plant base operating cost. The coal plant NPV is approximately twice as sensitive to such variations.

\subsubsection{NPV Sensitivity to Power Credit}

The case 7 coal plant generates approximately $38 \%$ more net electrical power and it is therefore more sensitive to changes in the credit allowed for this power generation.

\subsubsection{NPV Sensitivity to Availability}

Both nuclear and coal plants exhibit a rather high sensitivity to plant availability, with coal plants being more sensitive than nuclear plants.

\section{6 .9 Use of Table 4-13}

Table 4-13 can be used in conjunction with Figure 4-24: to construct NP.Vs for coal and nuclear plants not actually analyzed. Variations in the economic parameters should be limited to +10 percent for good accuracy, except that coal price variations of up to +50 percent will yield accurate results. Variations in excess of those stated will be less accurate and should be attempted with caution. For variations in escalation rates, +1 percentage point will yield good accuracy. Variations larger thañ 1 percentage point will yield doubtful accuracy. Availability variations should not exceed 15 percent.

This table has been constructed from analyses performed on nuclear case 5 and coal case 7 with concurrent construction start dates, and its use should be limited to these cases. 
CASH FLOW SUMMAKY

CLIENT - DUFONT (NUCLEAR)

PSE JOB - 4027
FUEL CYCLE $5 R$

(TABLE 4-2)

\begin{tabular}{|c|c|c|c|c|c|c|c|c|c|c|}
\hline YEAR & $\begin{array}{c}\text { (1) } \\
\text { CAFITAL }\end{array}$ & $\begin{array}{r}(2) \\
\text { BACKUF }\end{array}$ & NET (3) & $\begin{array}{l}\text { (4) } \\
\text { INUESTMENT }\end{array}$ & $\begin{array}{l}\text { (5) } \\
\text { FUEL }\end{array}$ & $\begin{array}{c}\text { (6) } \\
\text { OFERATING }\end{array}$ & $\begin{array}{l}\text { (7) } \\
\text { TOTAL }\end{array}$ & $\begin{array}{l}\text { (B) } \\
\text { IEEFEECIATION }\end{array}$ & $\begin{array}{l}\text { (9) } \\
\text { INTROA. }\end{array}$ & $\begin{array}{c}(10) \\
\text { ADJUGTEI }\end{array}$ \\
\hline & EXF'ENSE & $\begin{array}{l}\text { OPERATING } \\
\text { EXFENSE }\end{array}$ & $\begin{array}{l}\text { IN WOHKING } \\
\text { CAFI I TAL }\end{array}$ & $\begin{array}{l}\text { CASH FLOW } \\
(1+2+3)\end{array}$ & EXFENSE & EXFENSE & $\begin{array}{l}\text { ANNUAL } \\
\text { EXFENSE } \\
(5+h)\end{array}$ & & EXFENSE & $\begin{array}{l}\text { OFELAGTING } \\
\text { EXFENSE } \\
(7-8+9)\end{array}$ \\
\hline
\end{tabular}

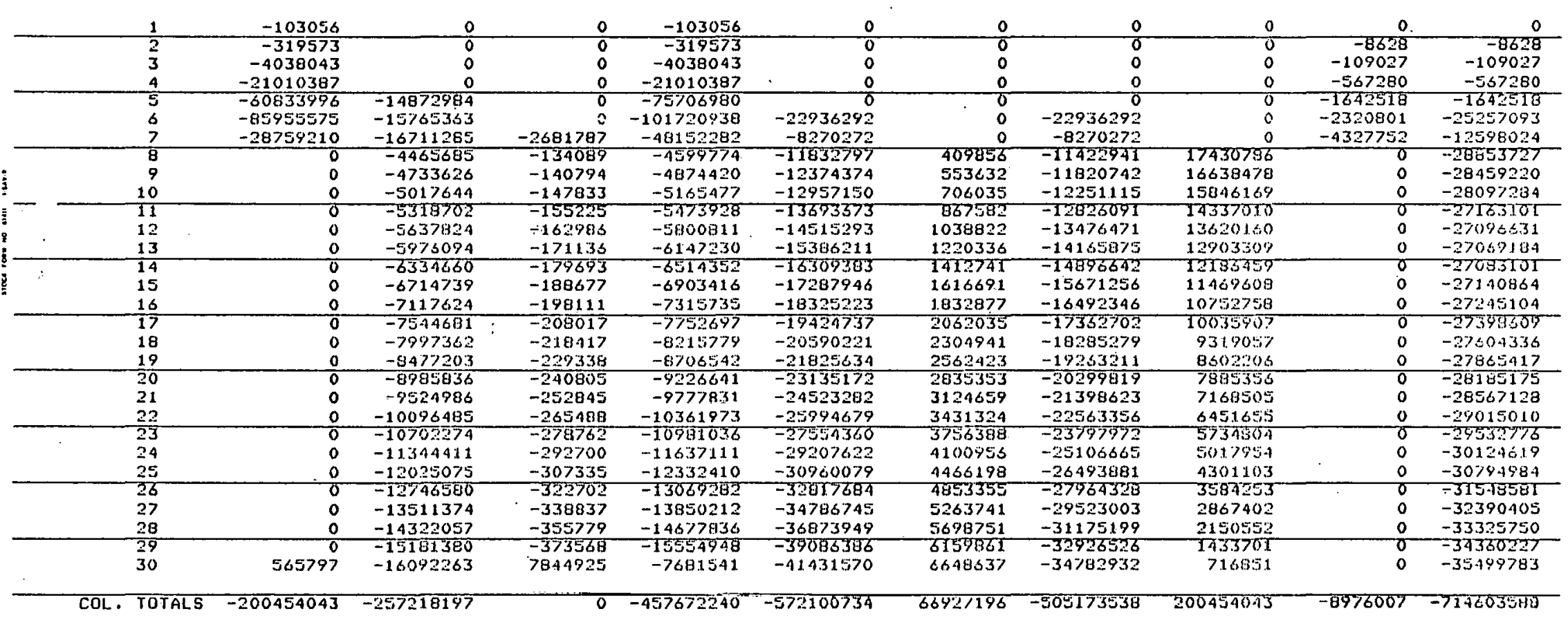


PSE JOE -4027

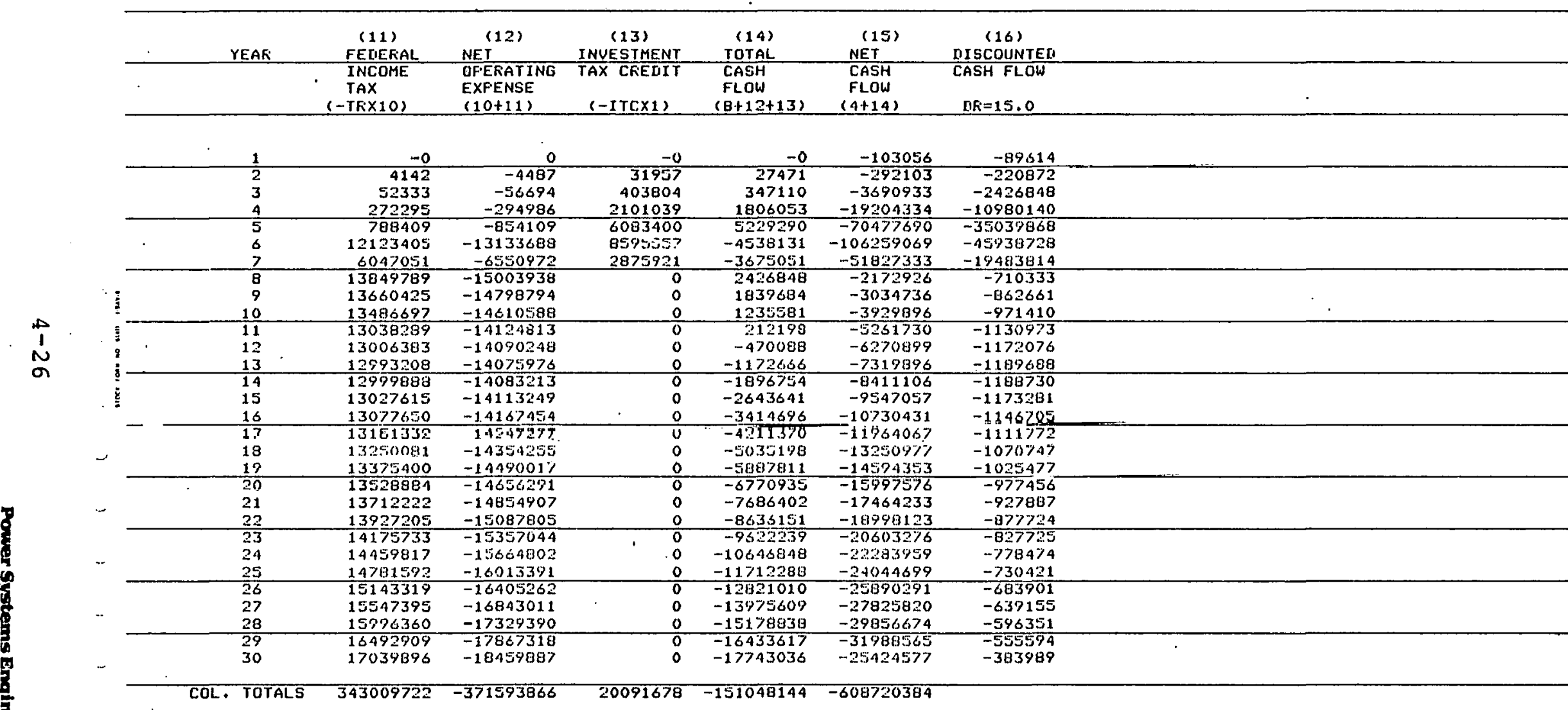

NET FRESENT VALUE $=-134912414$ 
ChIENT = DUPONT CH.S. COAL)

COAL PRICE $\$ 1.20 / 10^{6} \mathrm{BtU}$ CASE JÜ 7
PSE JUB
-4027

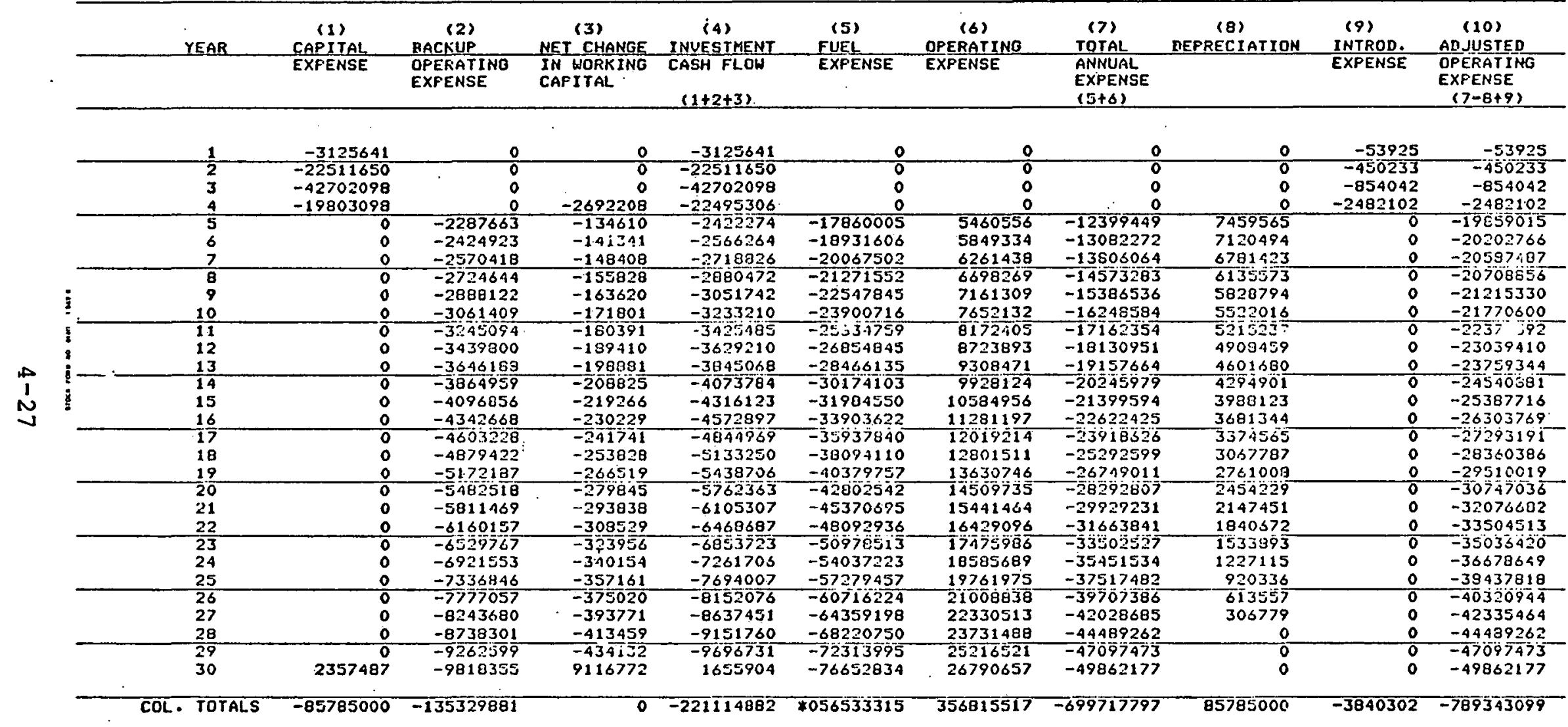

FIGURE 4-1 (Continued) 
PSE JOB -4027

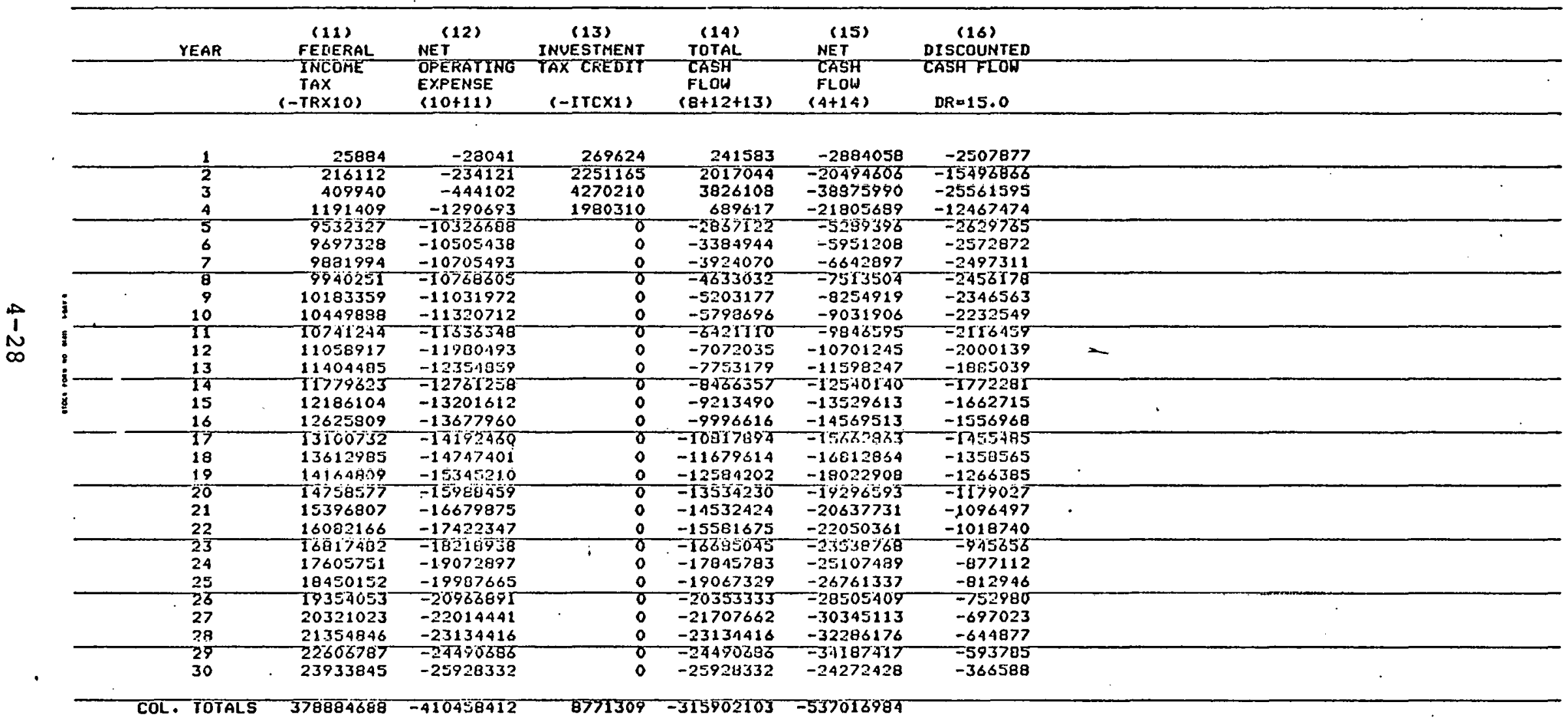

NET PRESENT UALUE $=-94828317$

FIGURE 4-1 (Continued) 
FIGURE 4-2 NUCLEAR FUEL CYCLE

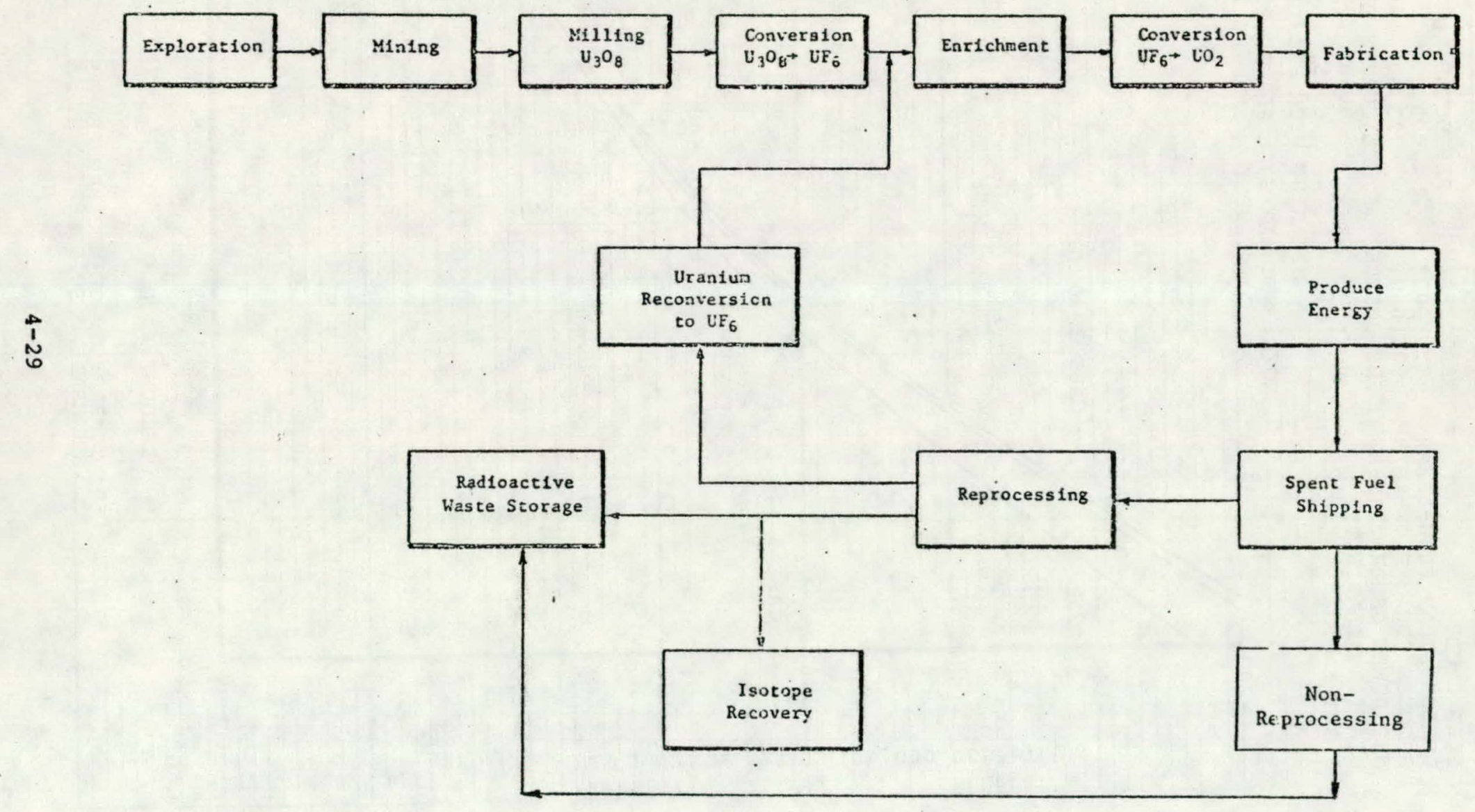




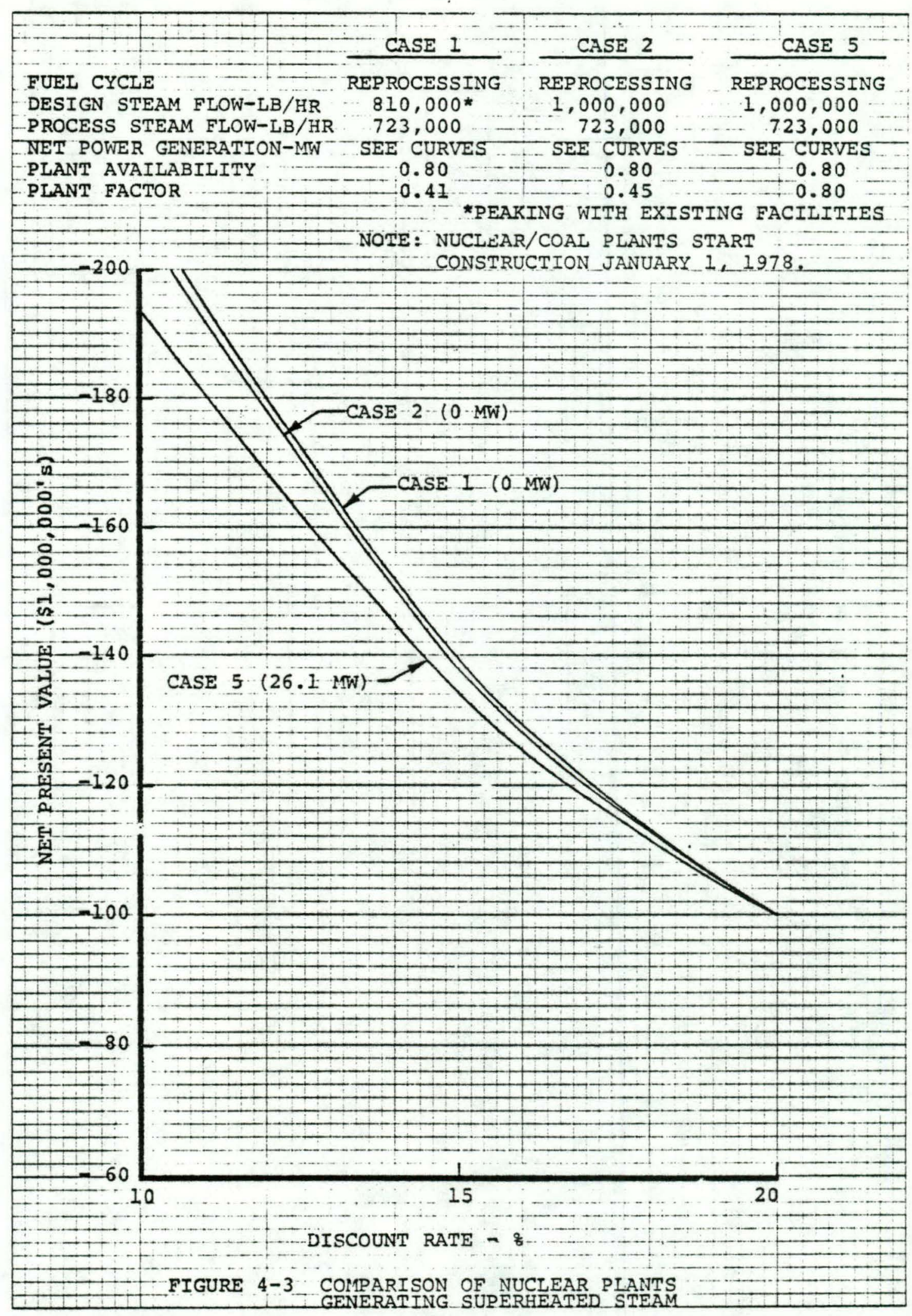




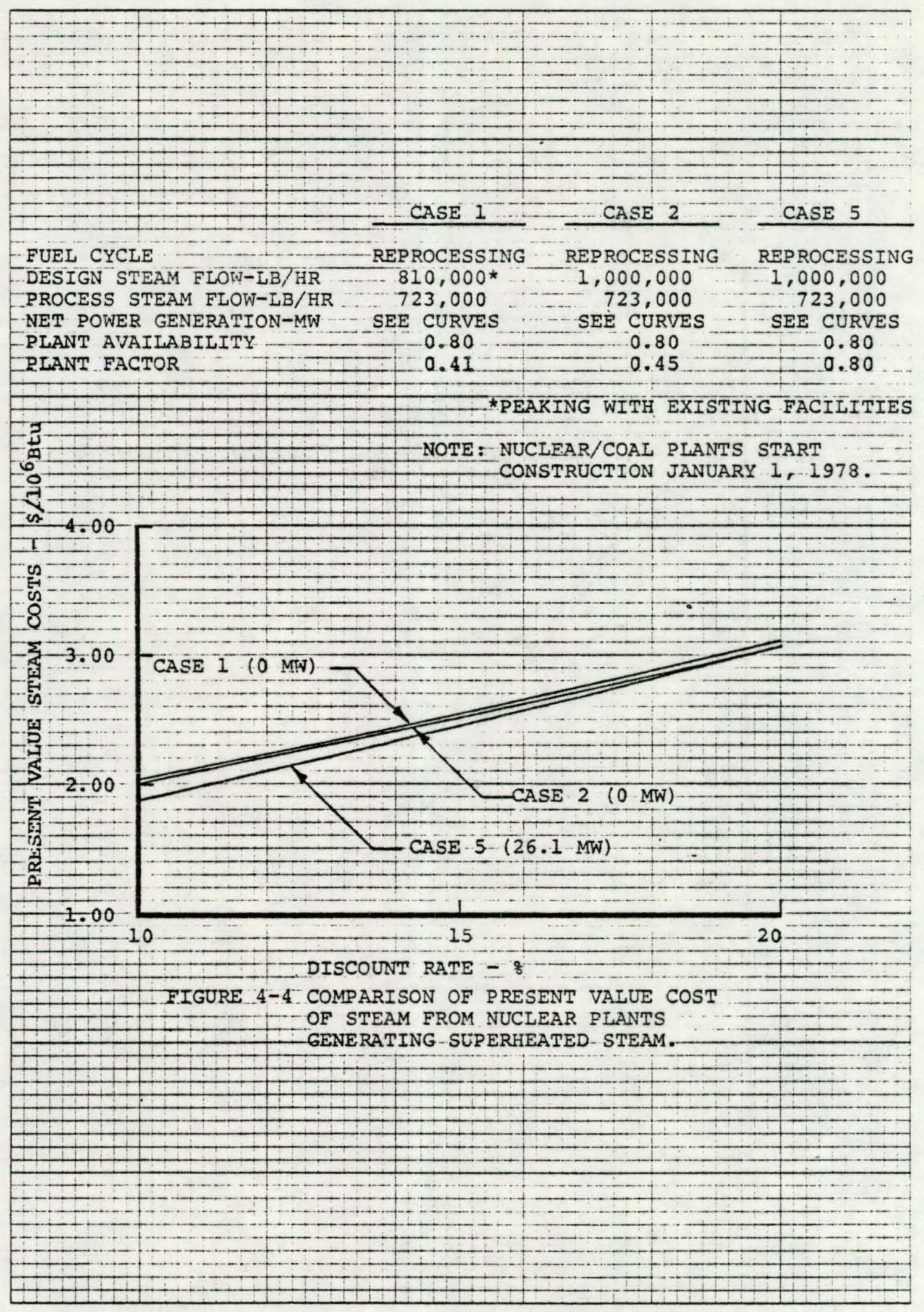

4-31 


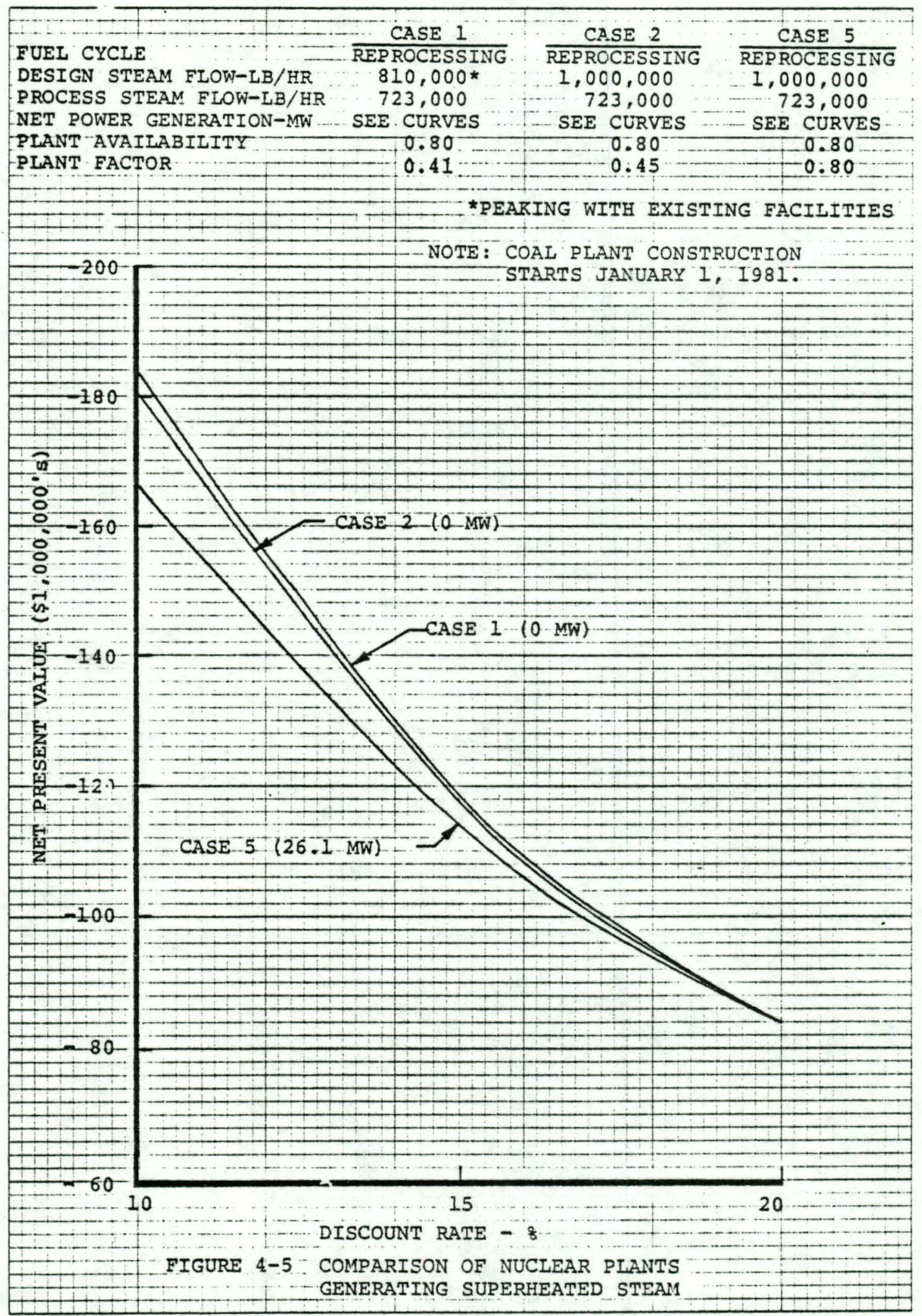

4-32 


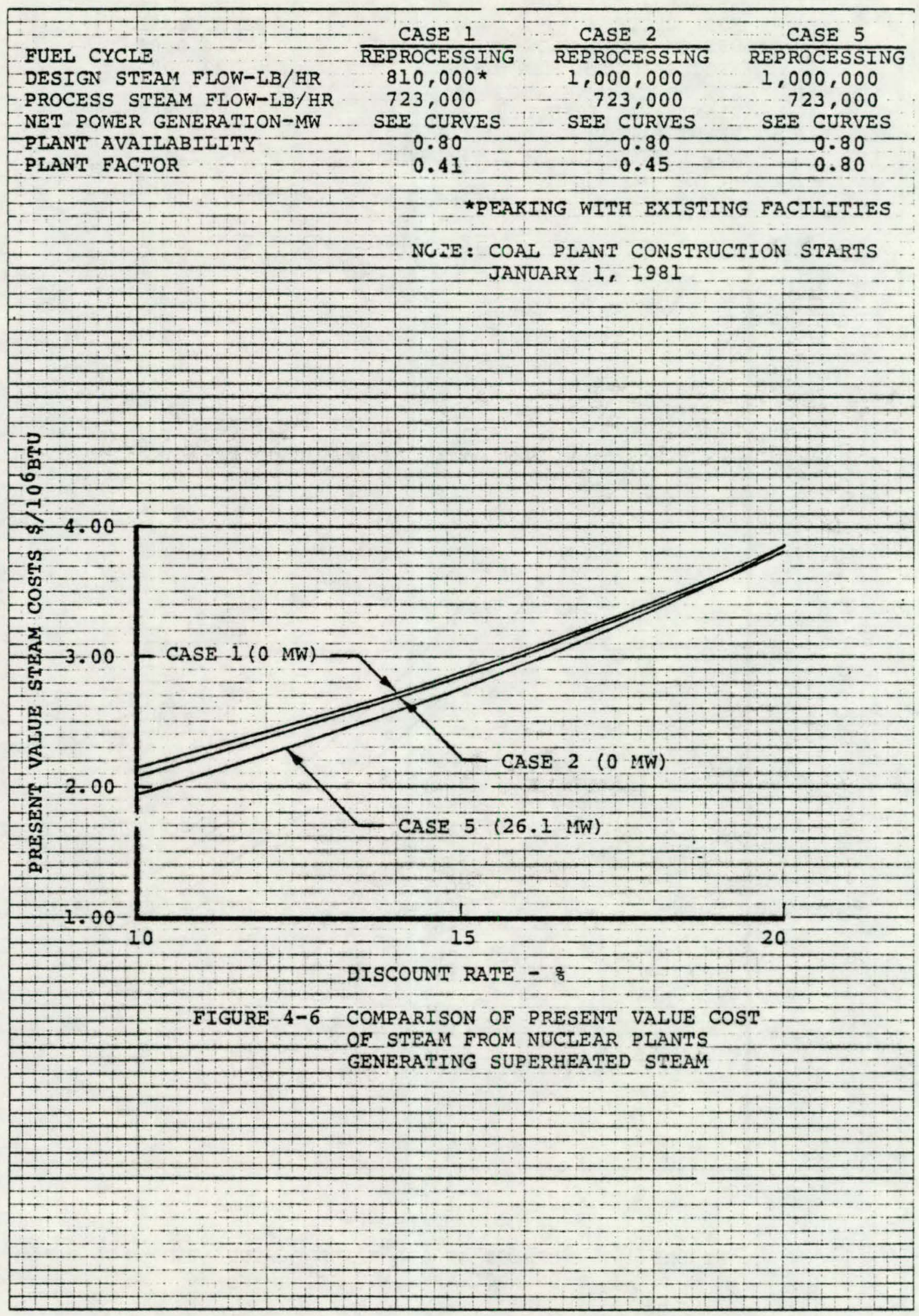




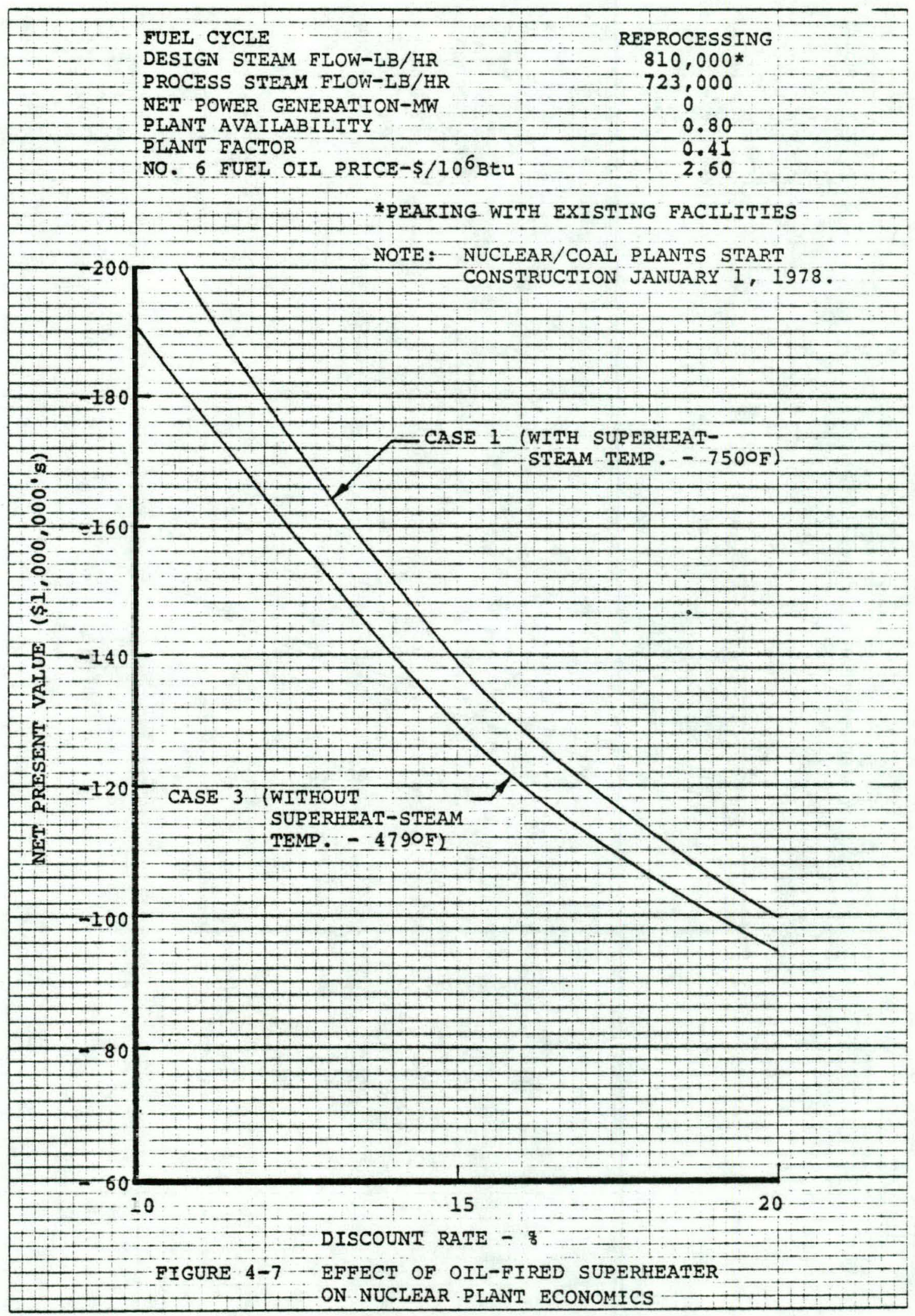




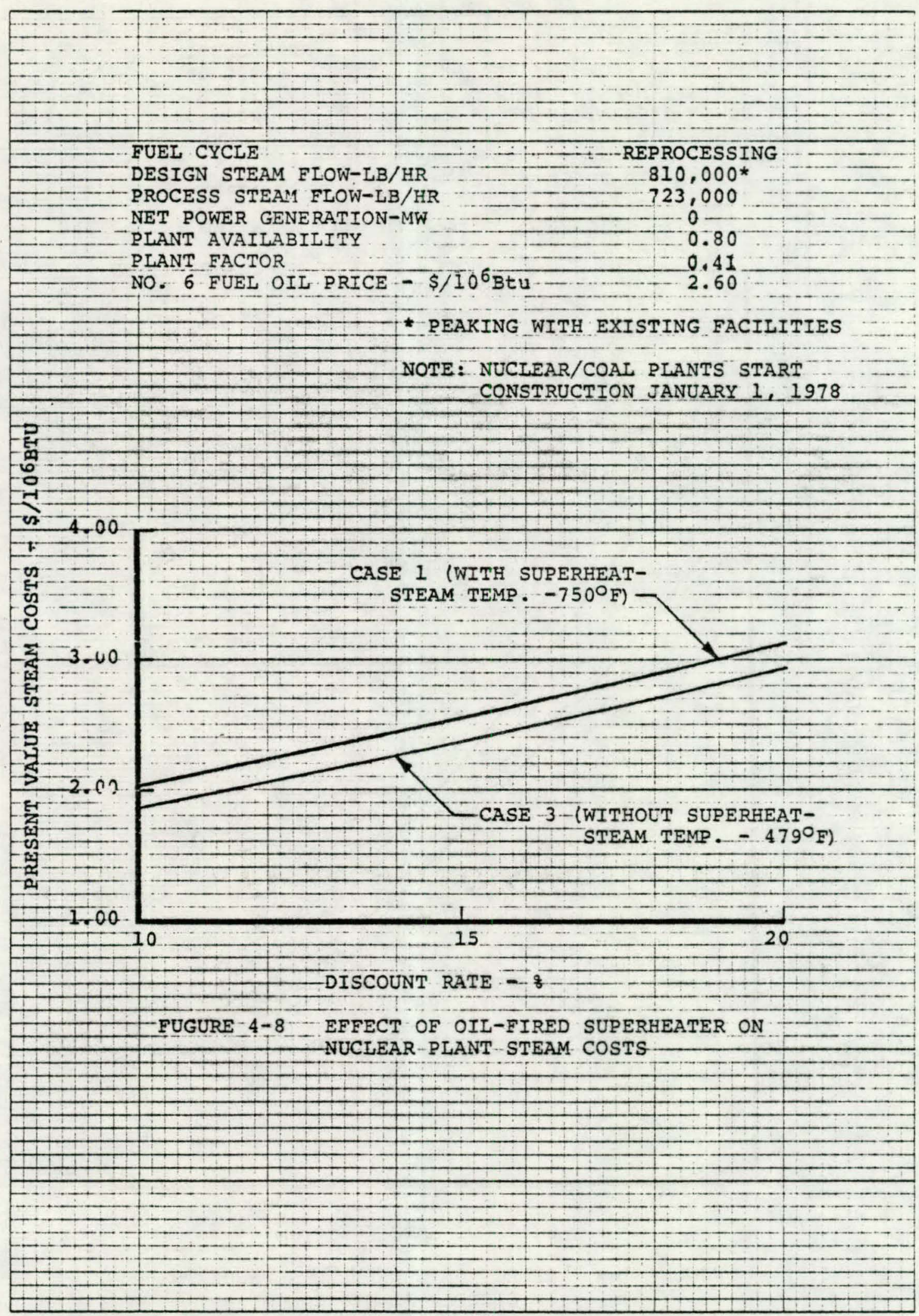

4-35 


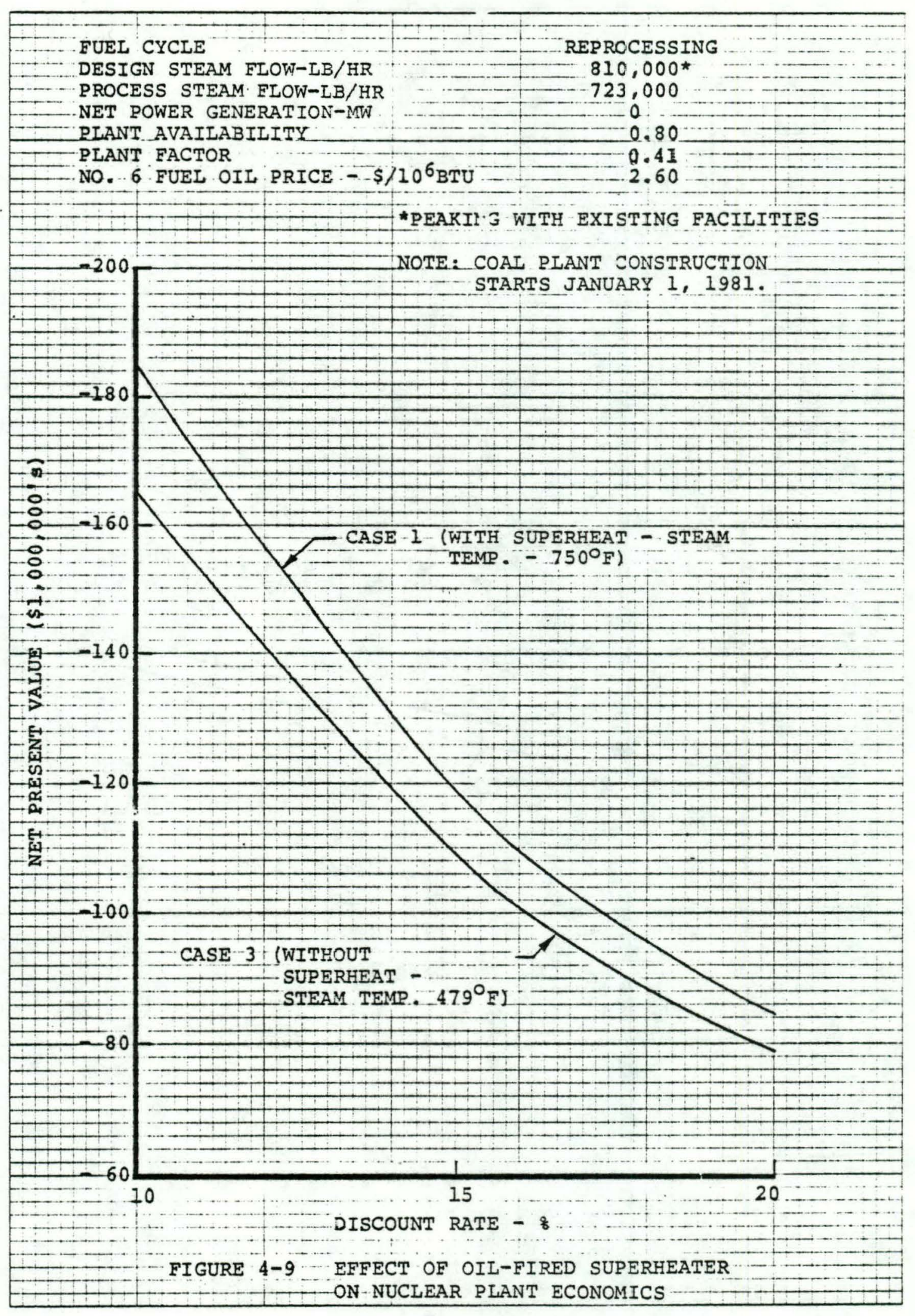

\section{4-36}




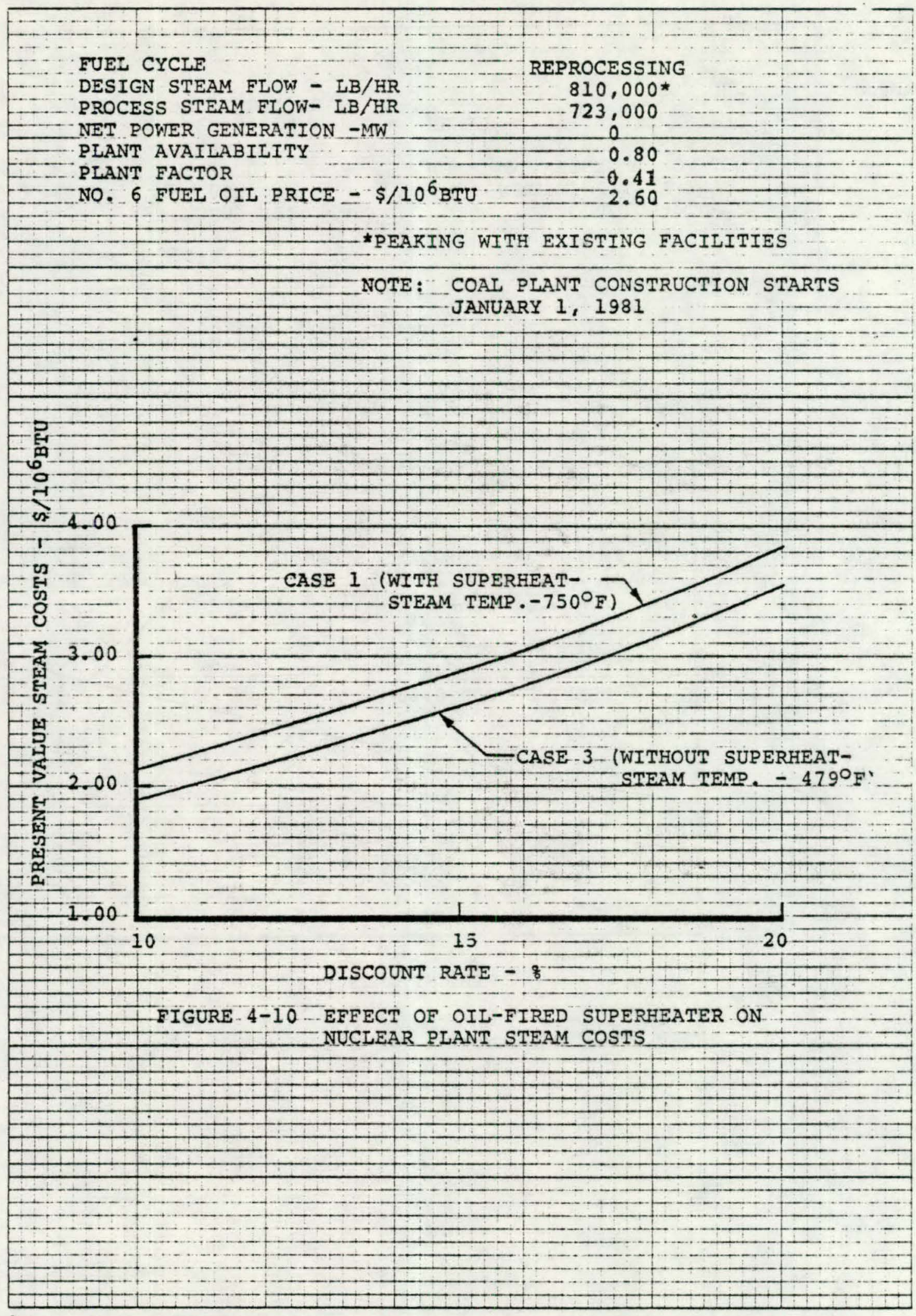




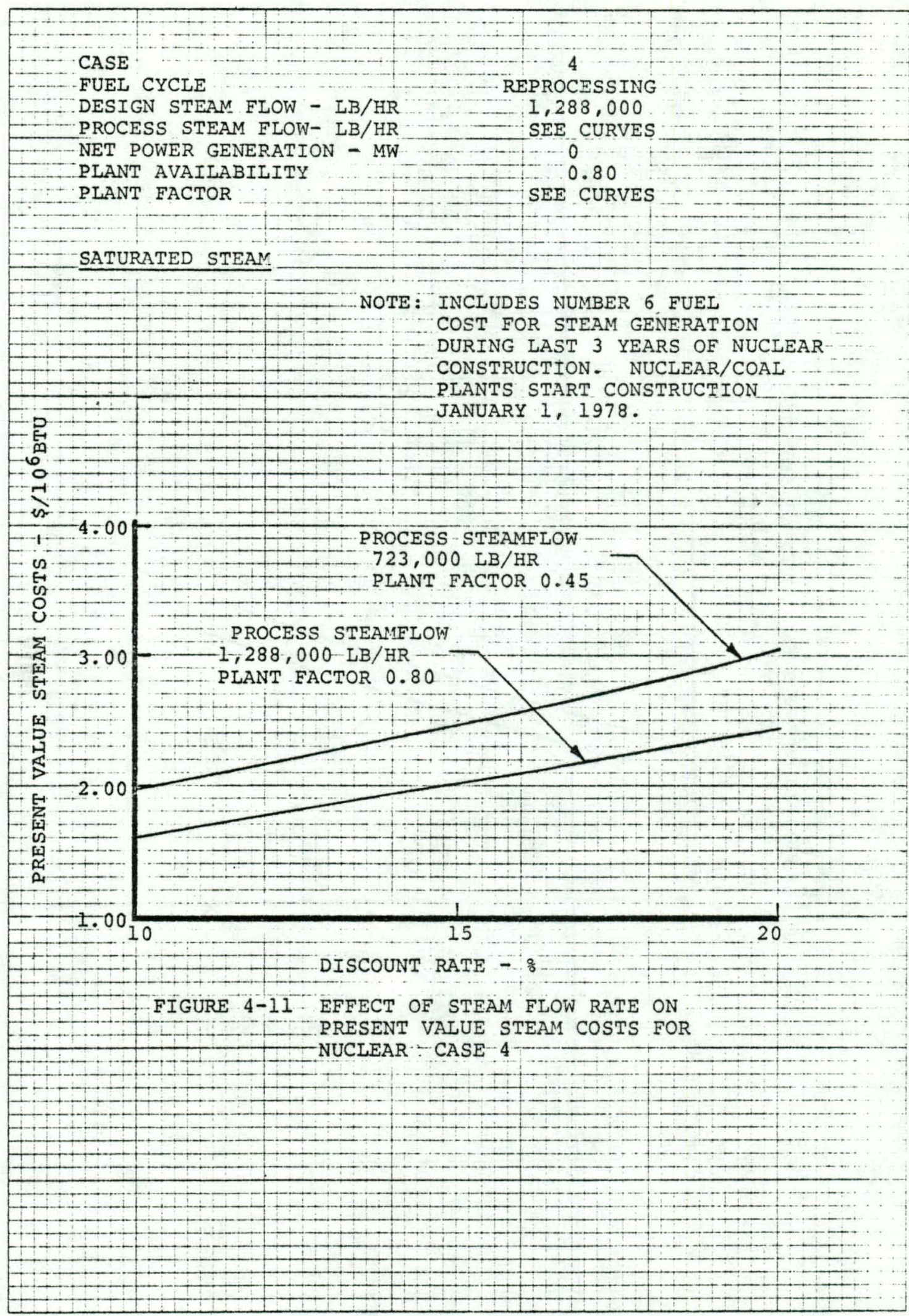

$4-38$ 


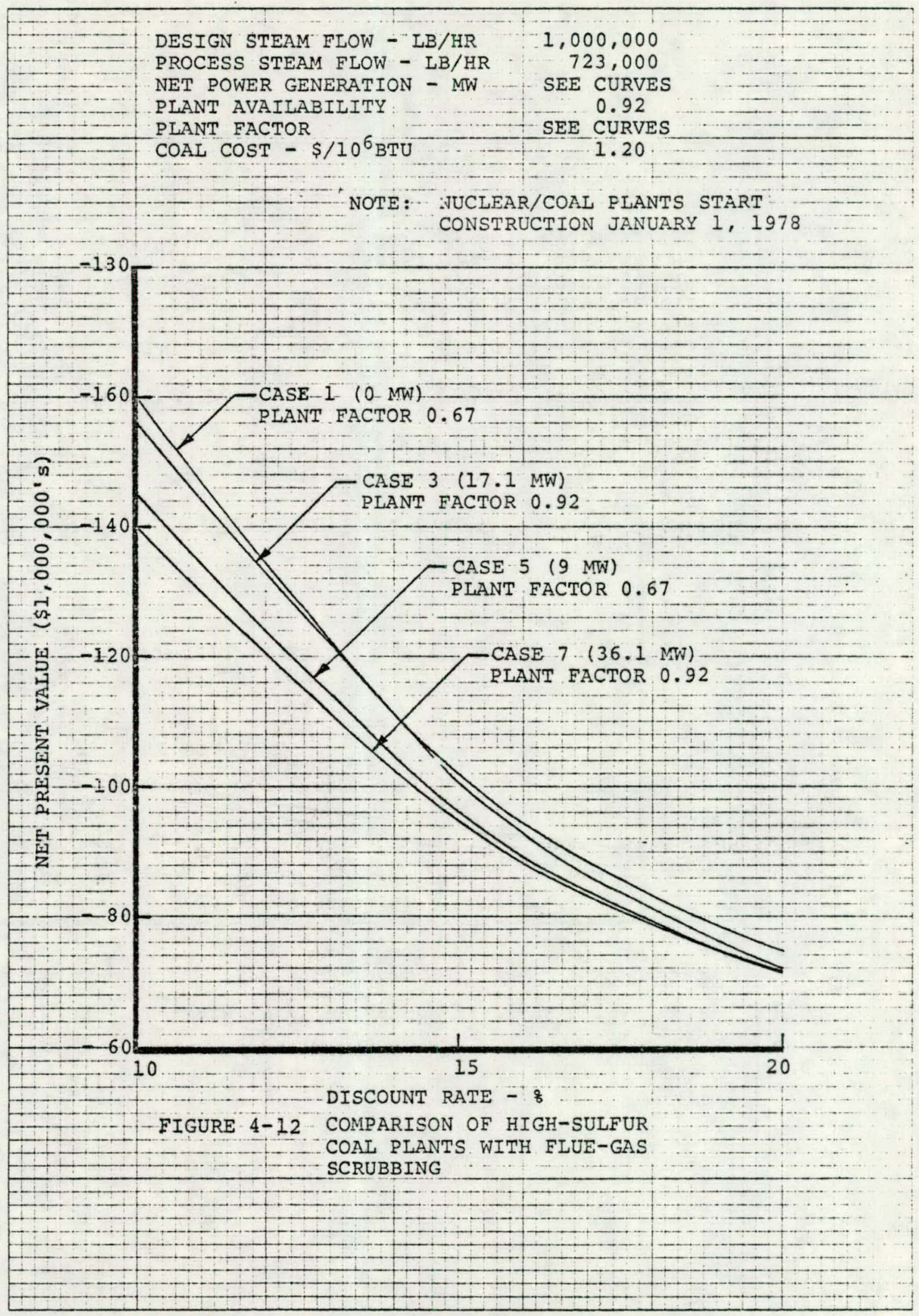

$4-39$ 


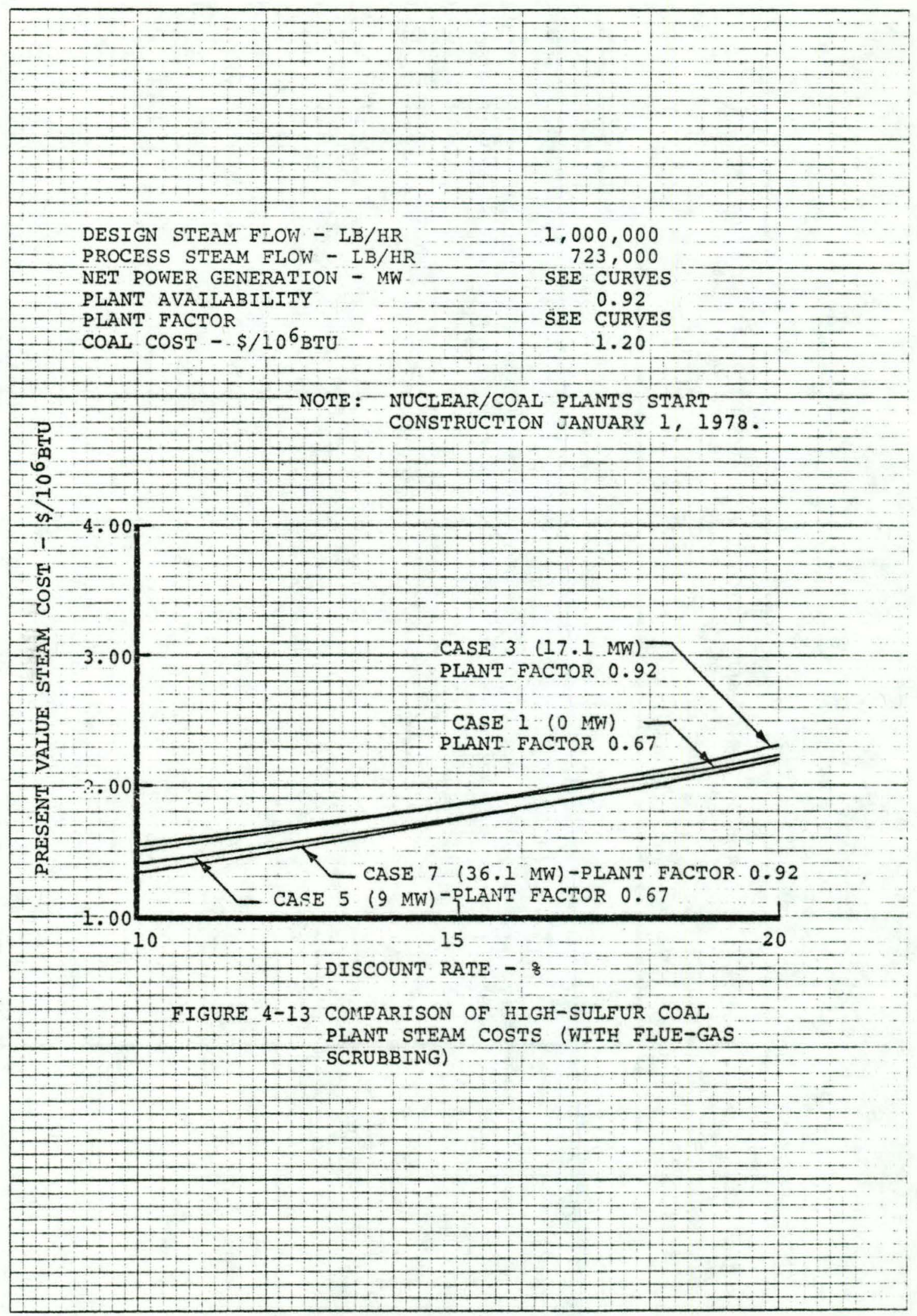

$4-40$ 


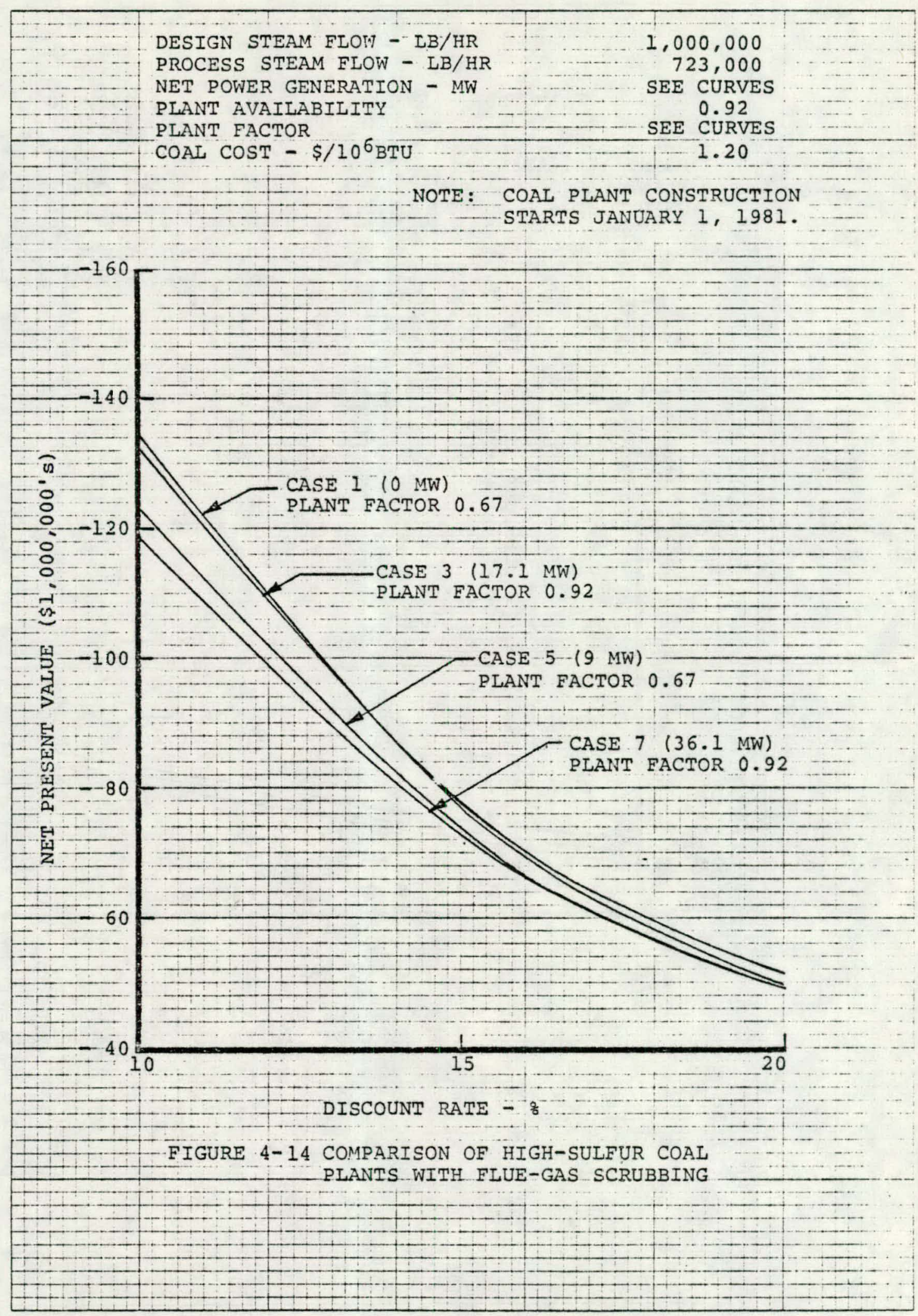

4-41 


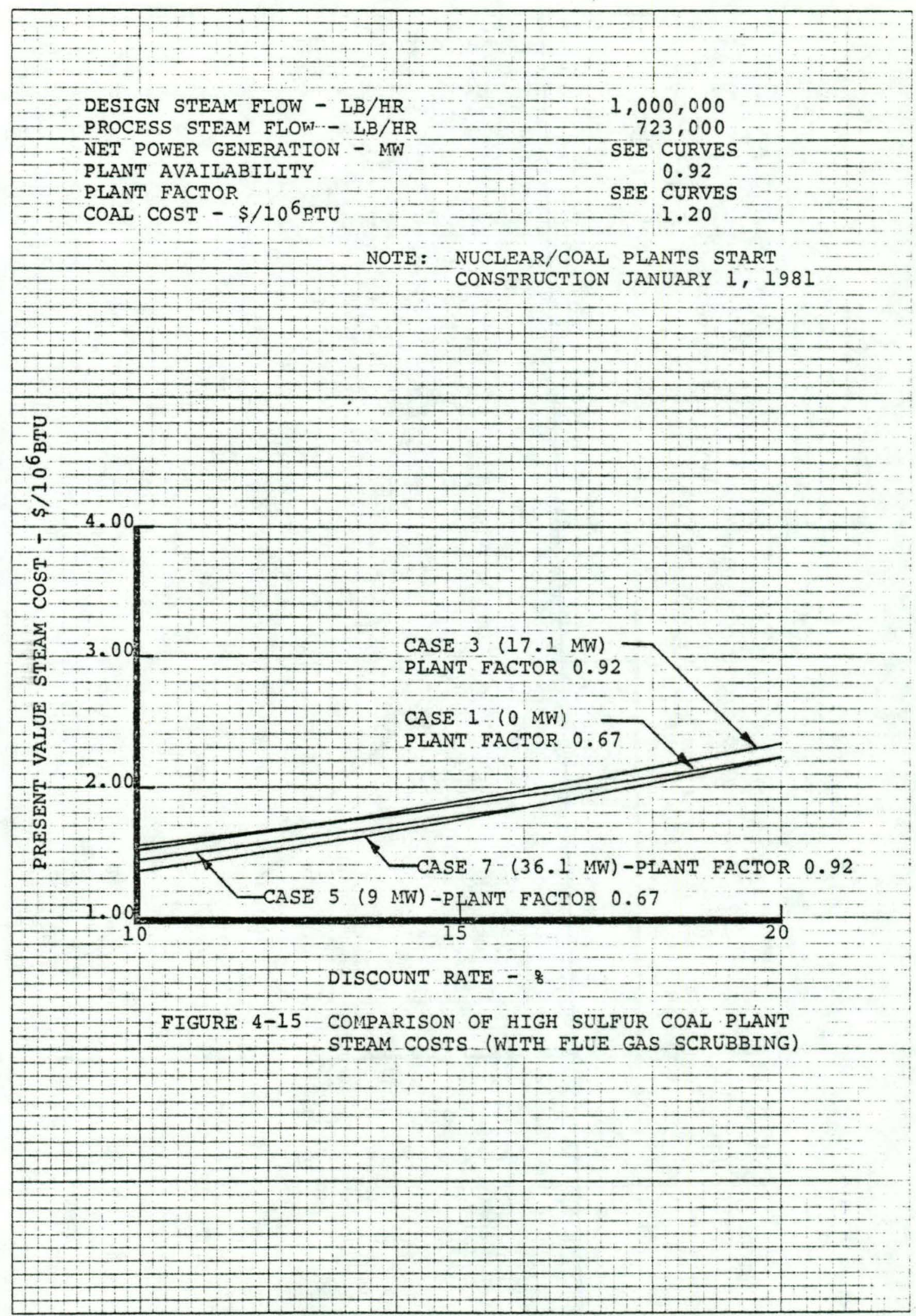




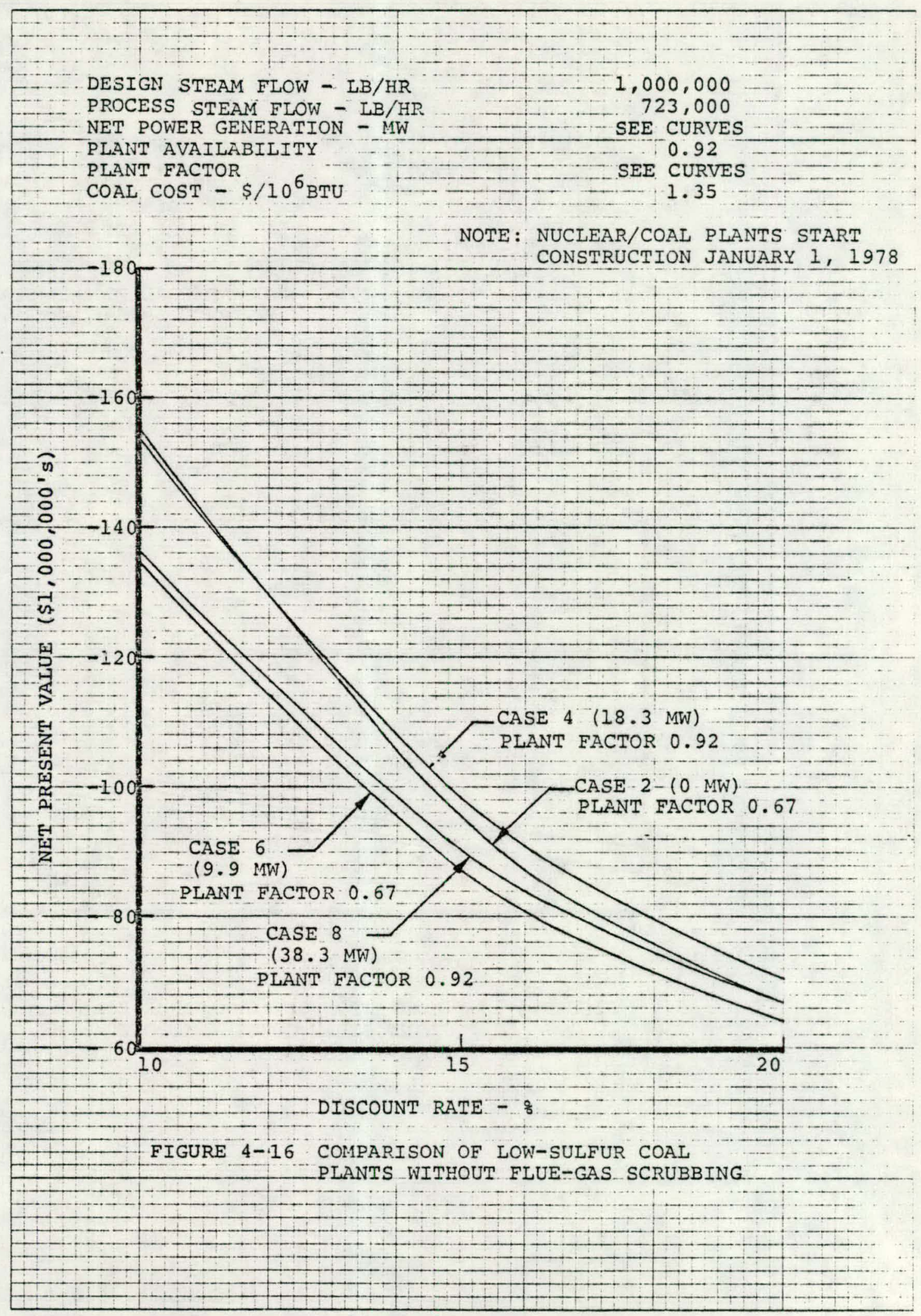




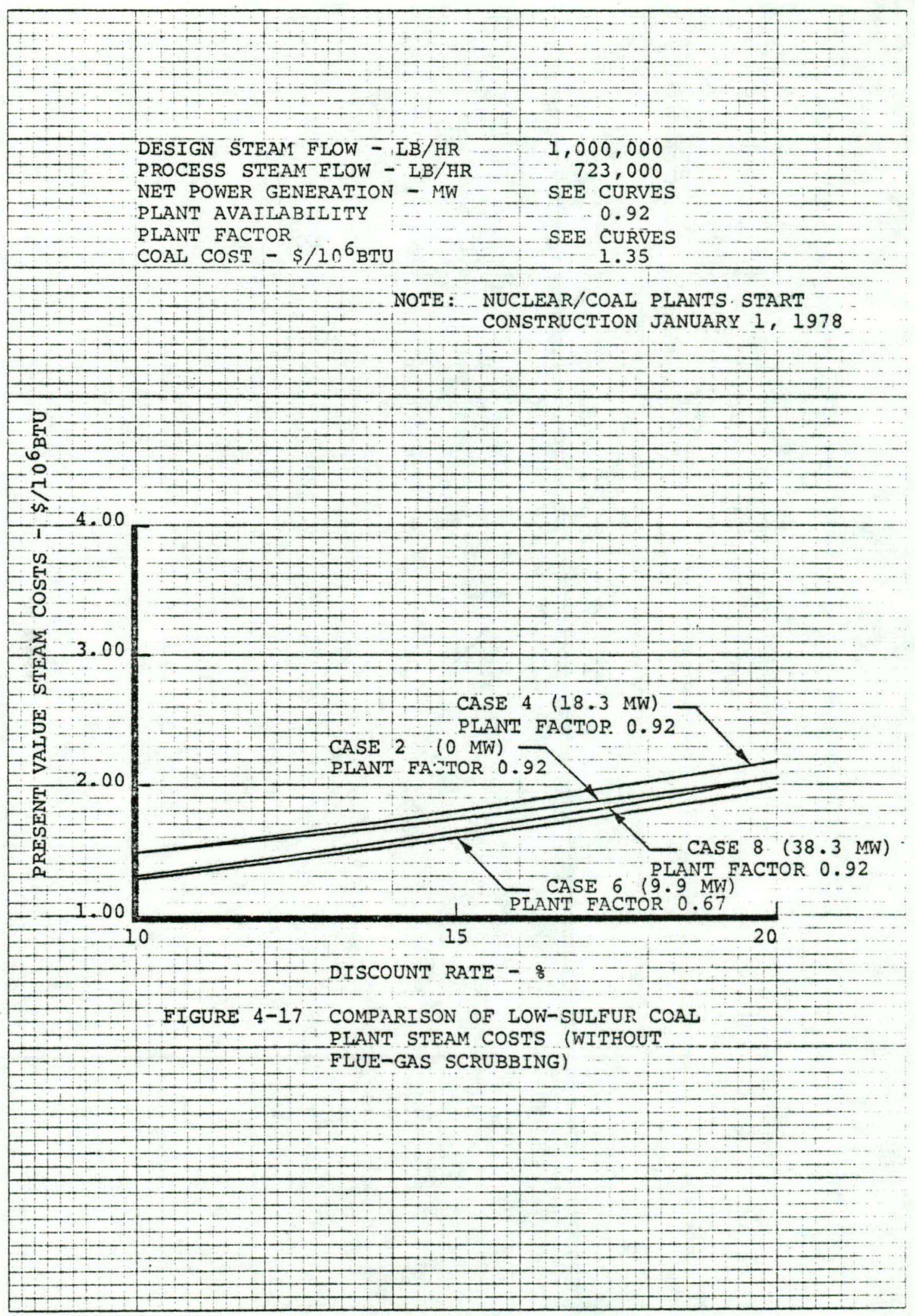

4-44 


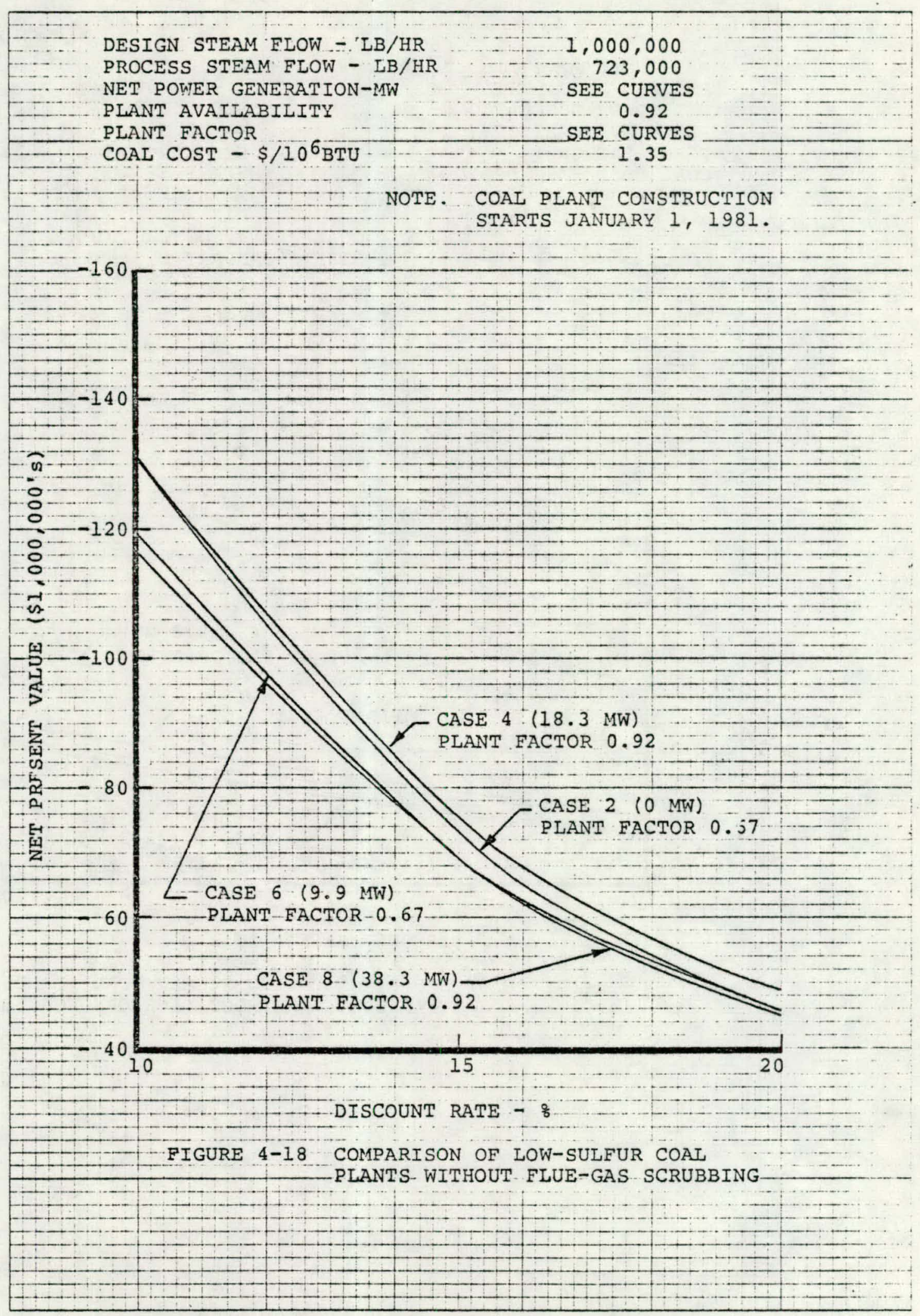




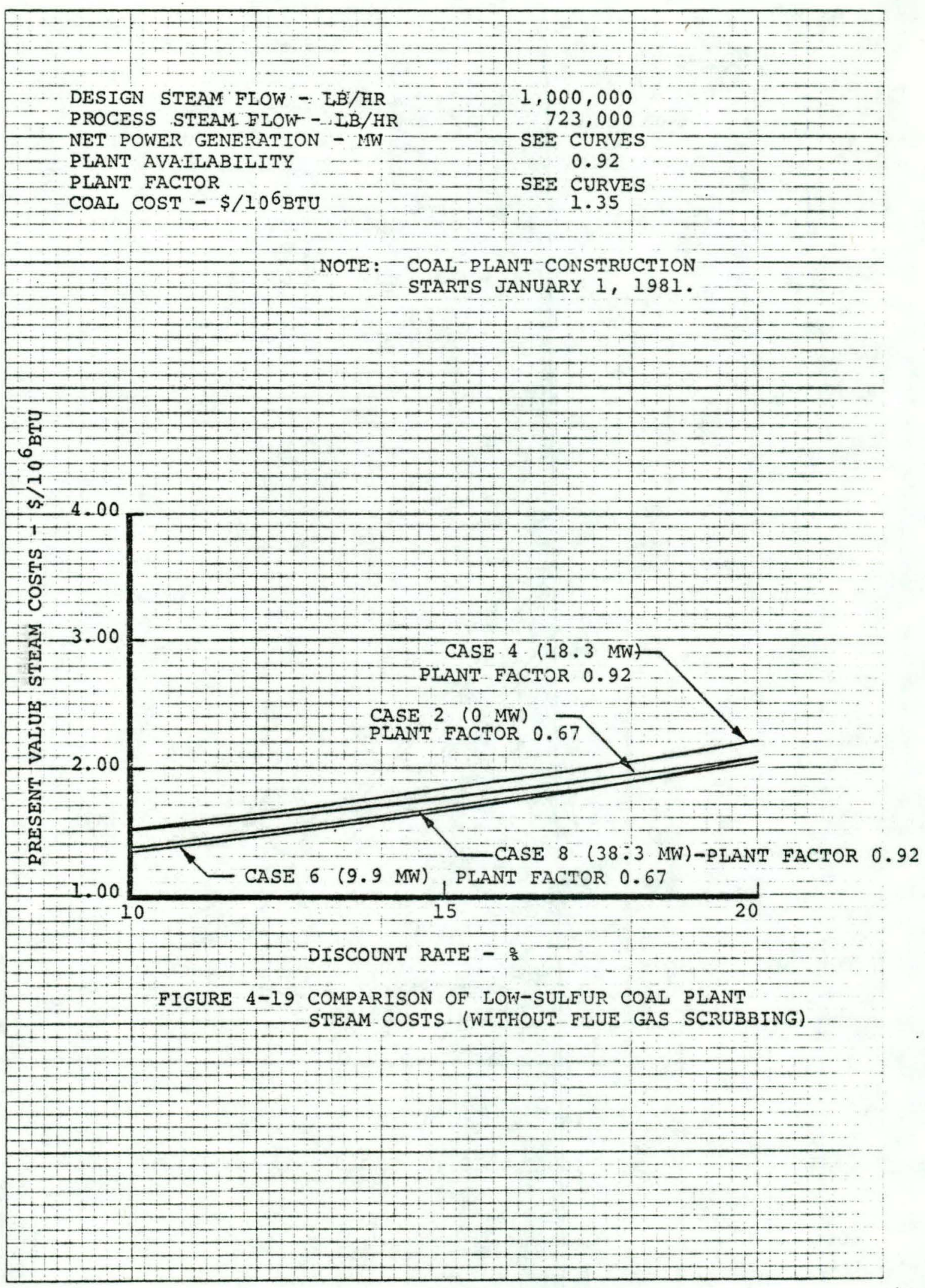

4-4 6 


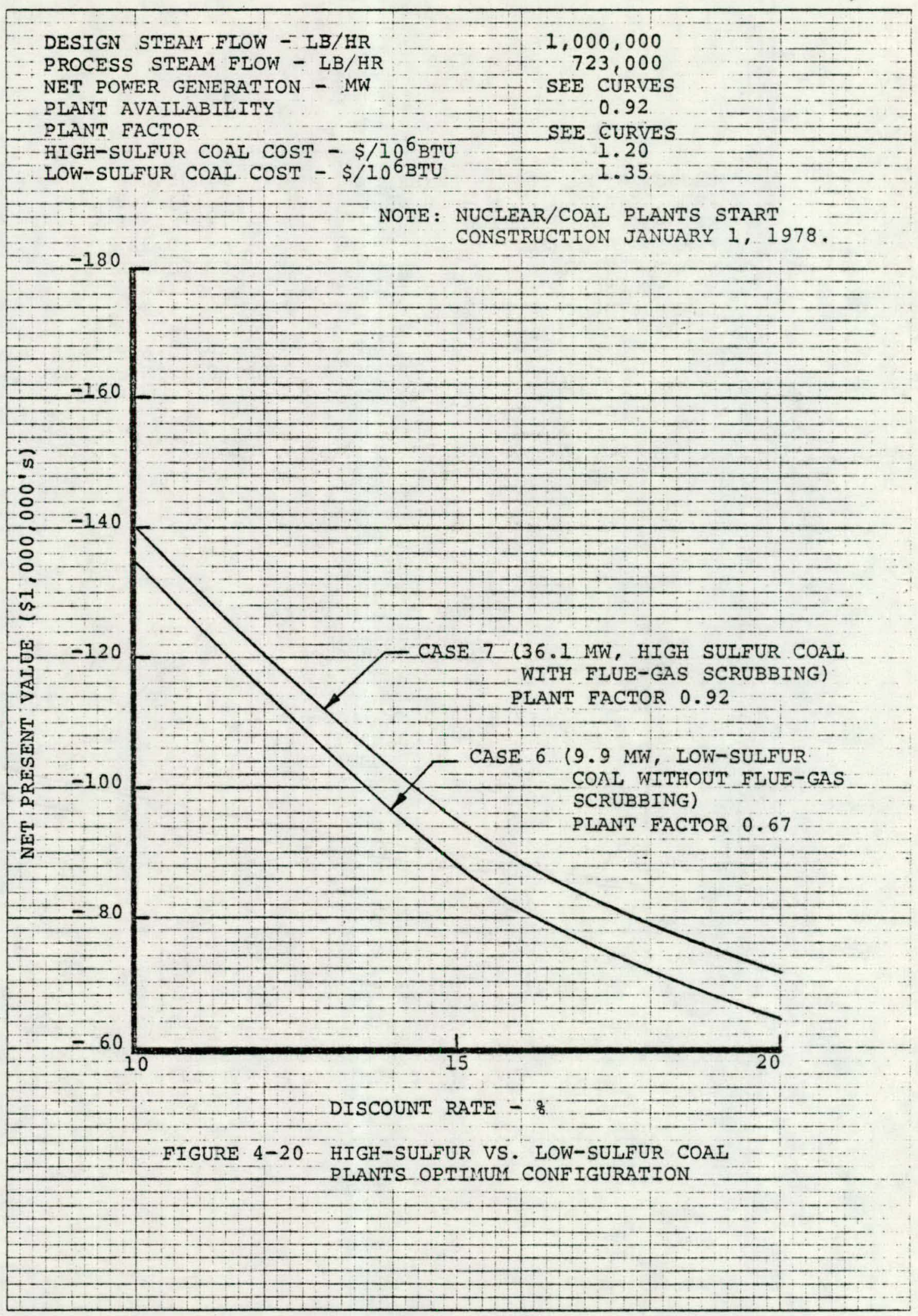




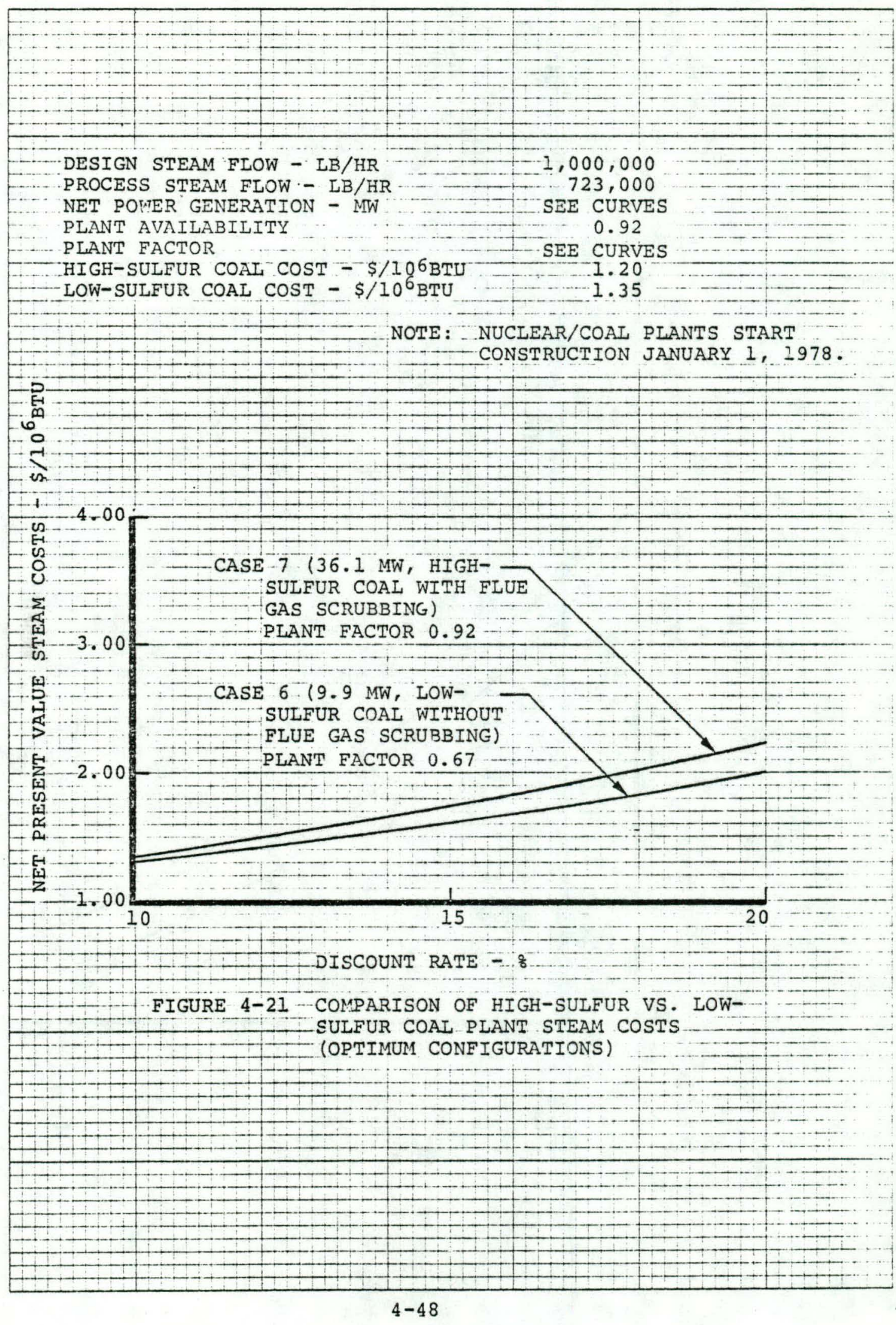




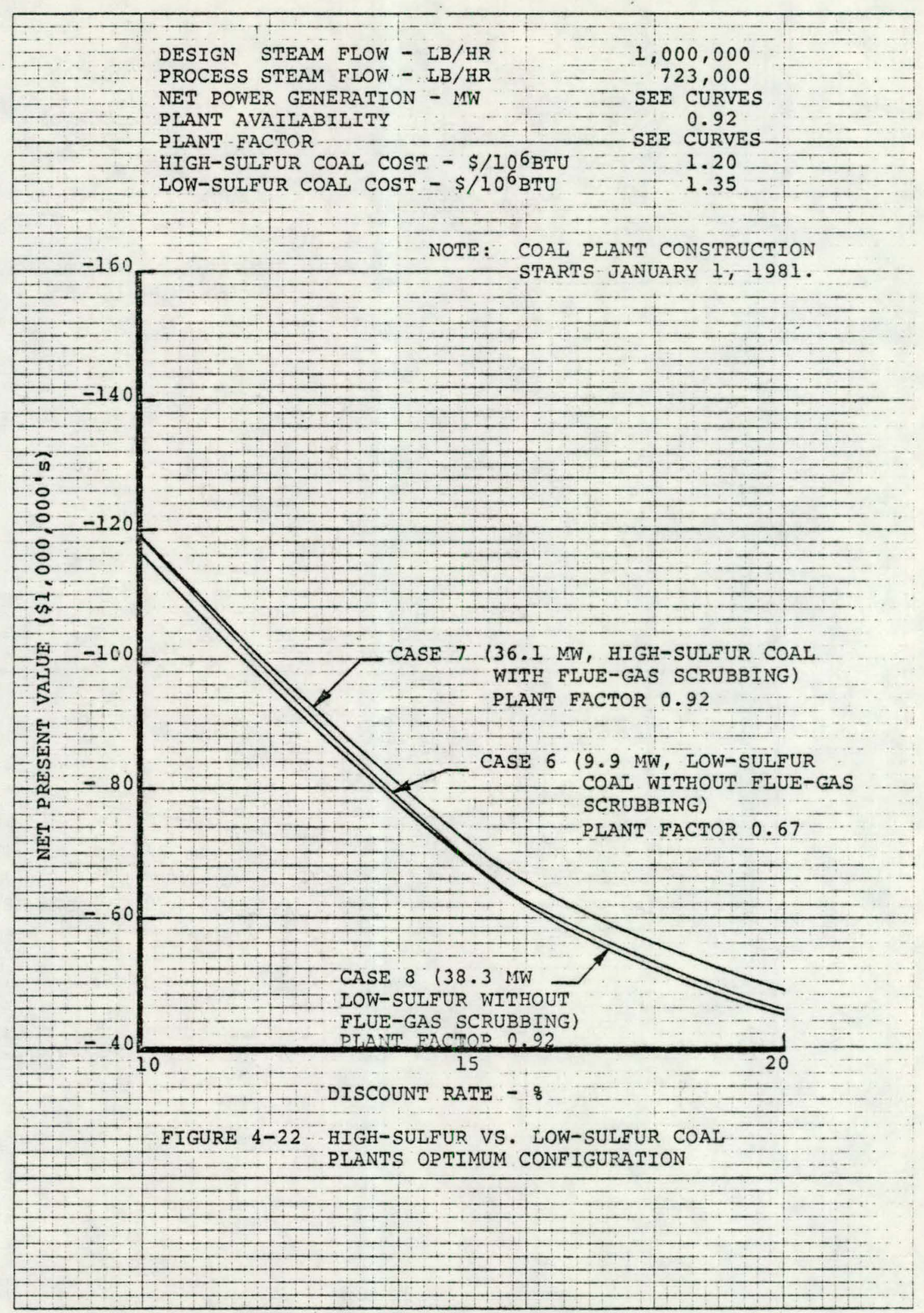

4-49 


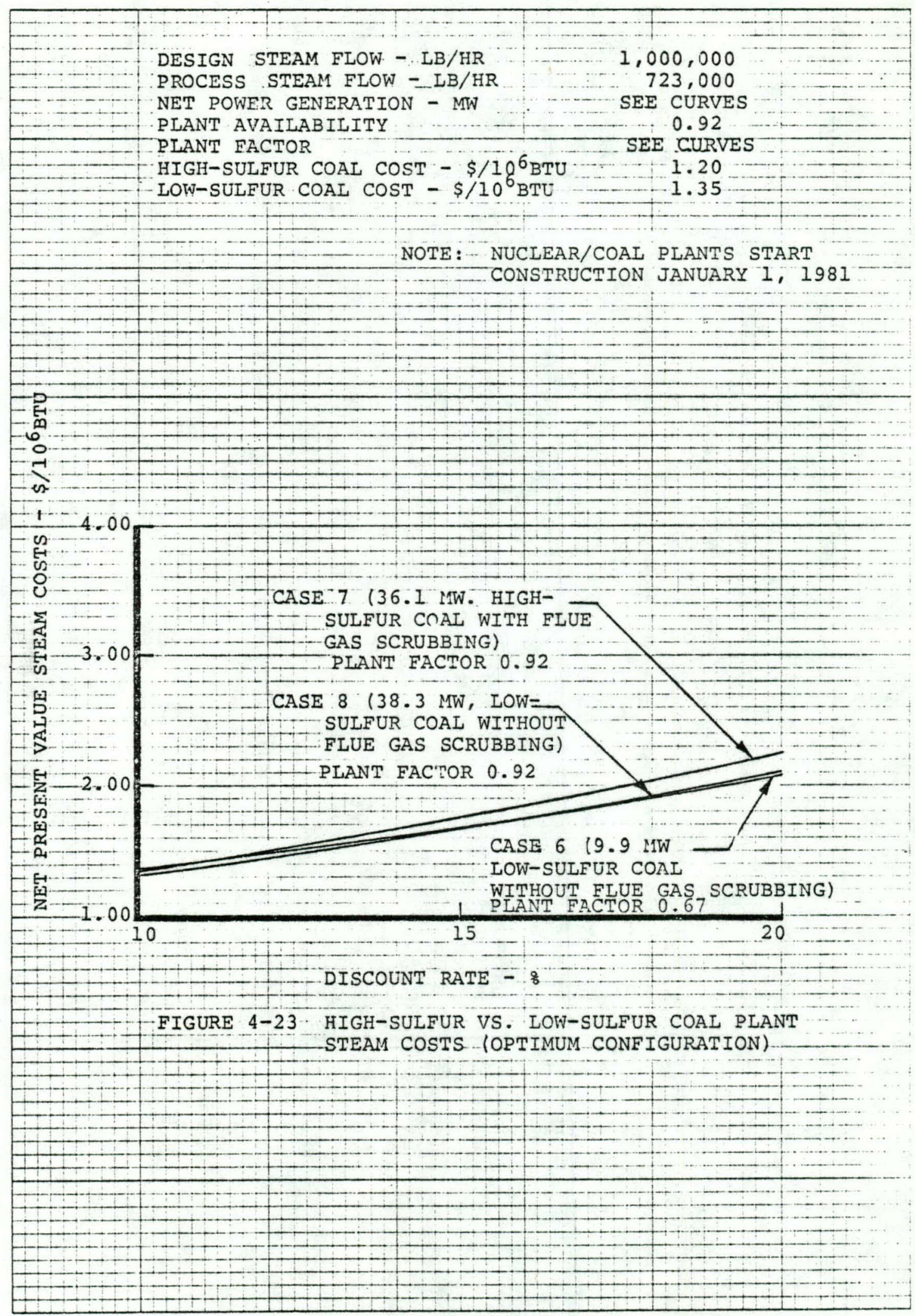

4. -50 


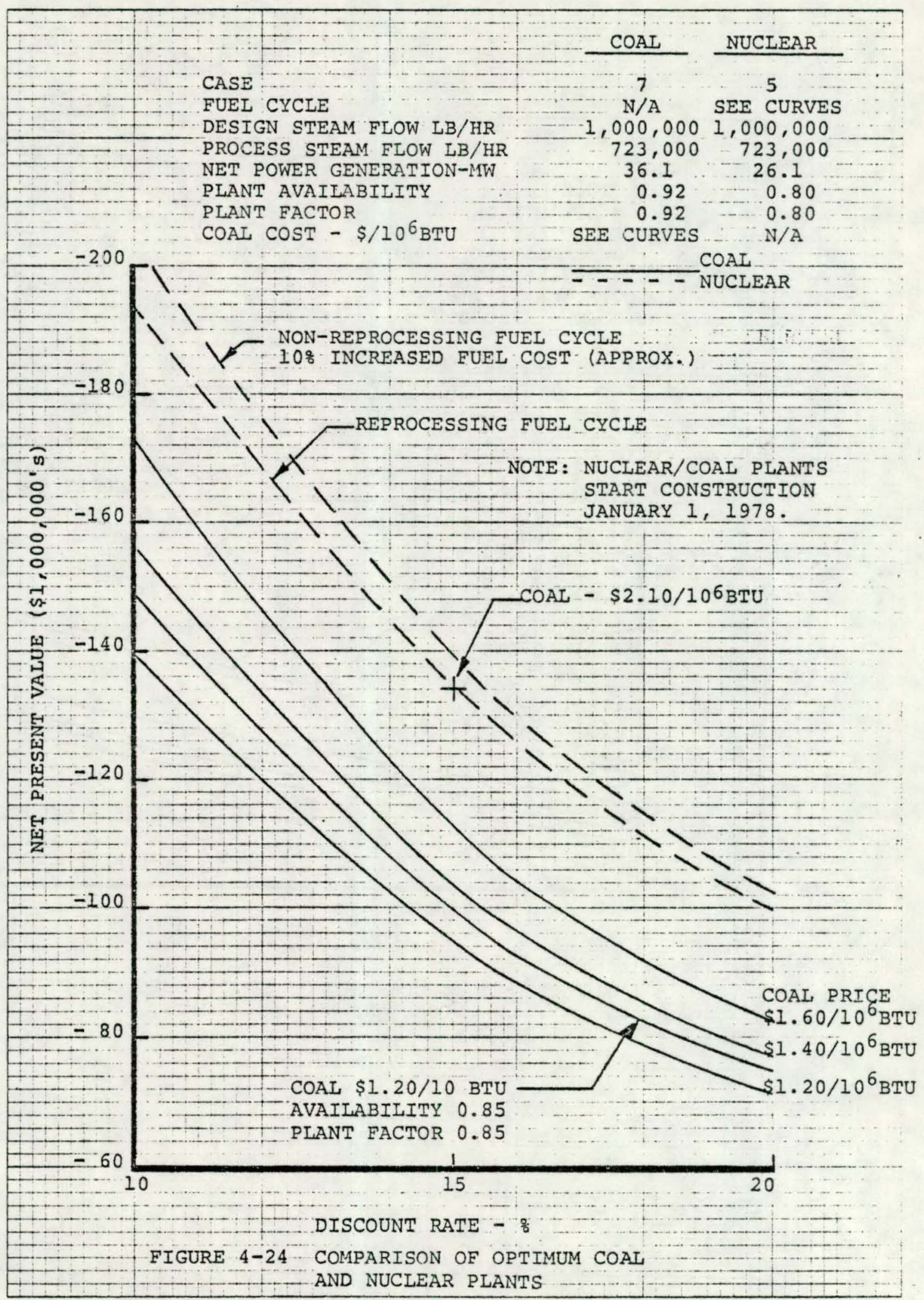

$4-51$ 


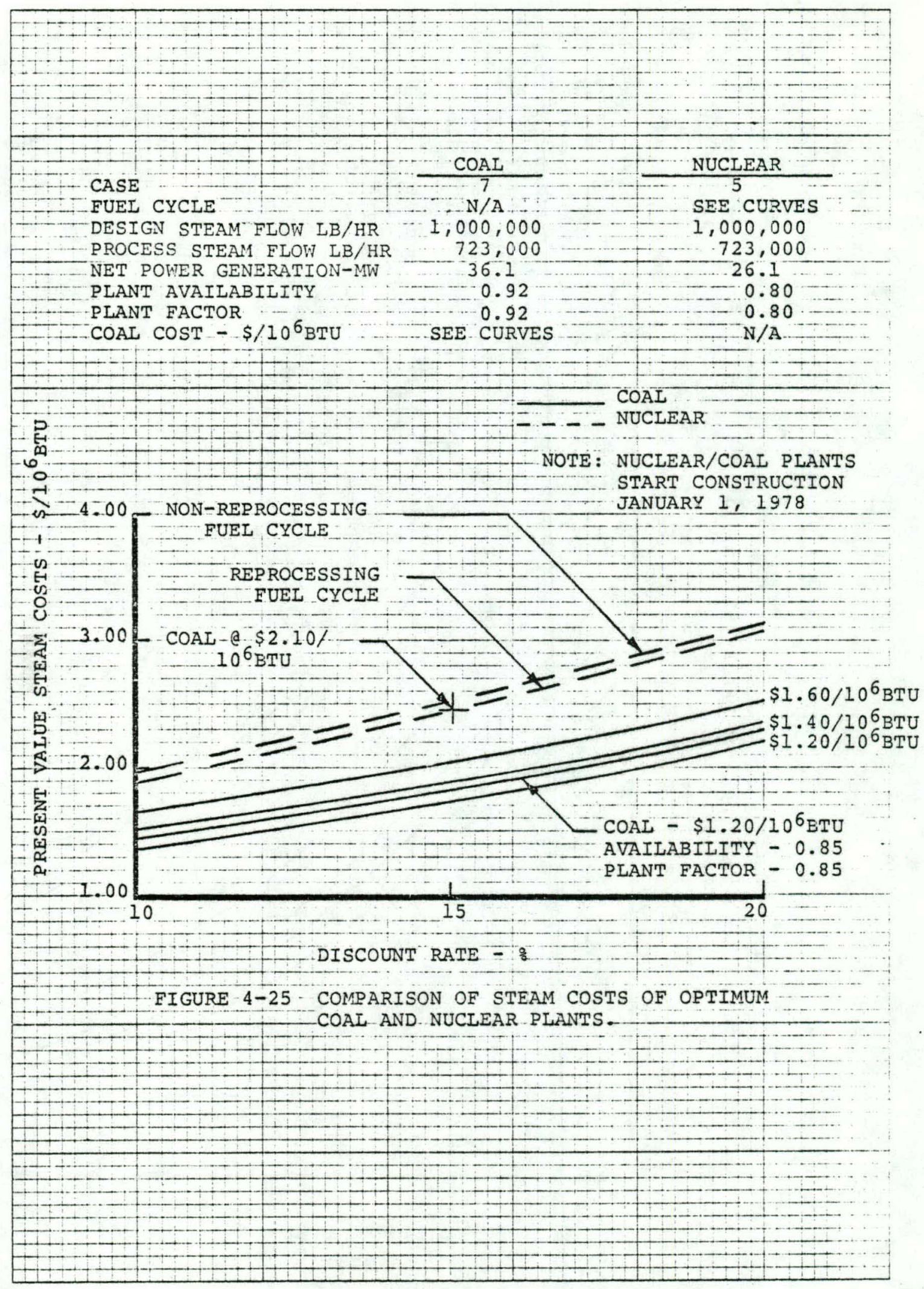

$4-52$ 


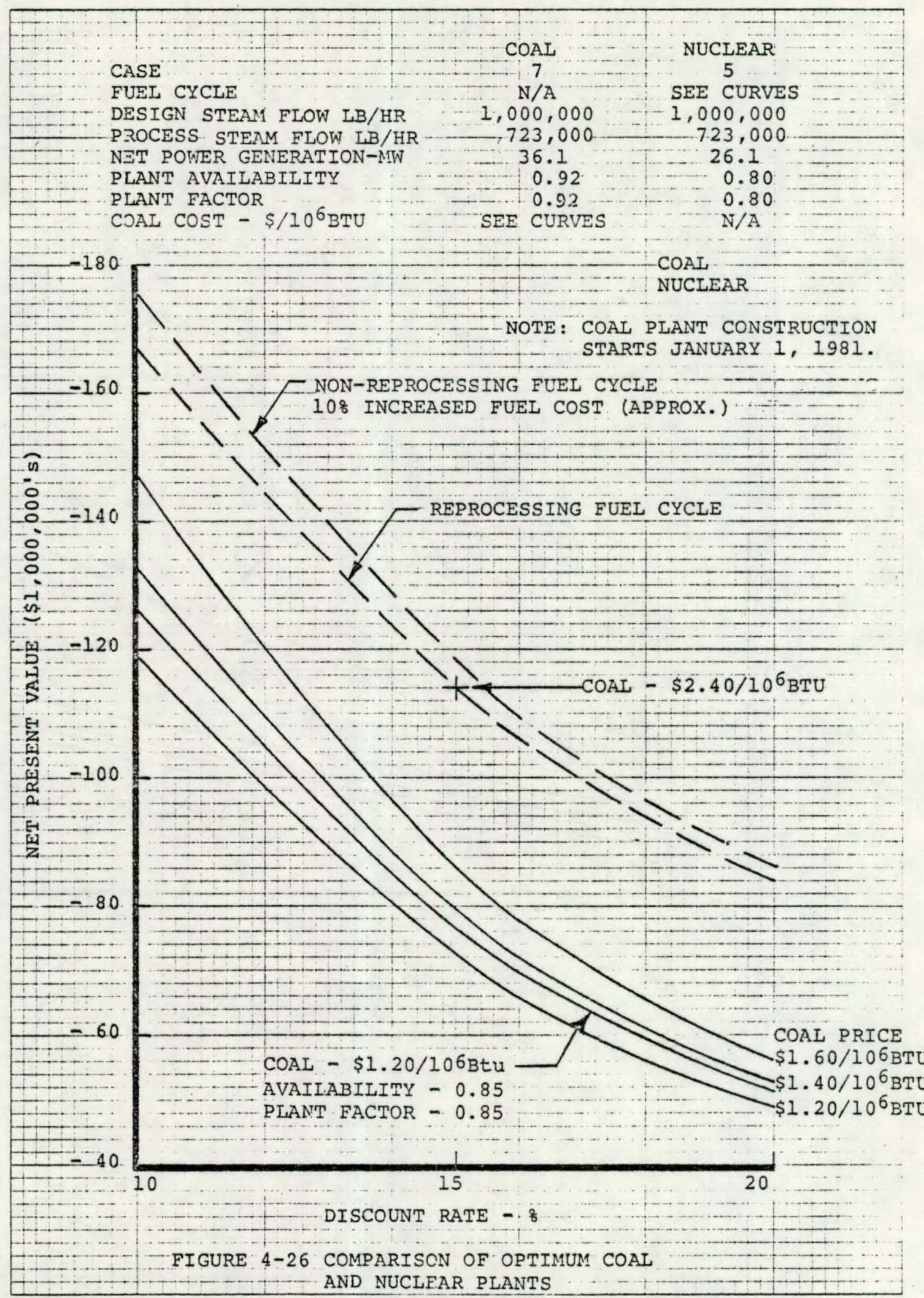

4-53 


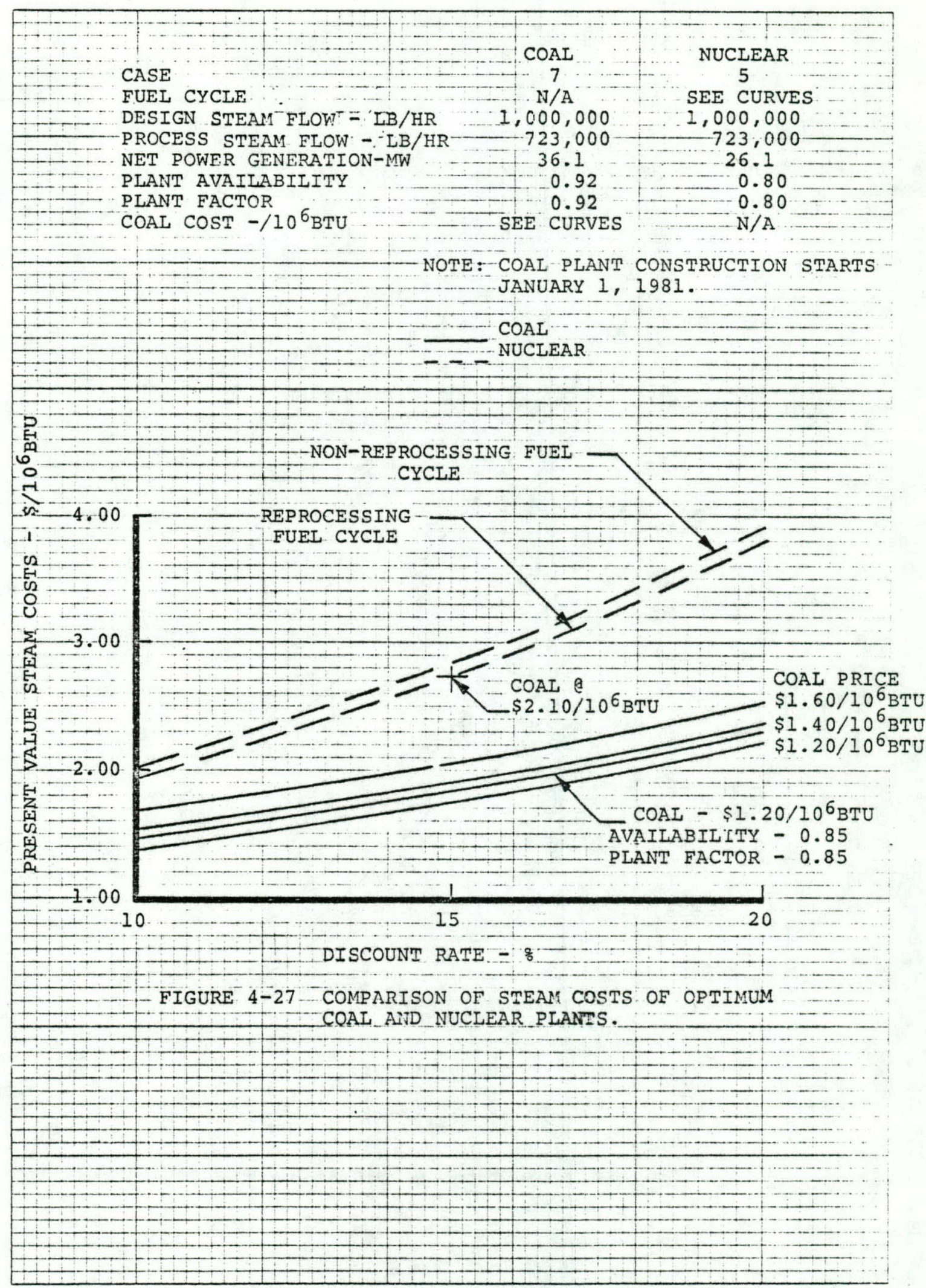


TABLE $4-1$

\section{ESCALATION RATE SCHEDUEES}

YEAR 1 YEAR 2 YEAR 3 YEAR 4 YEAR $5 \quad 6$ THRU 30

\begin{tabular}{|c|c|c|c|c|c|c|}
\hline $\begin{array}{l}\text { GENERAL } \\
\text { INFLATION }\end{array}$ & 6.0 & 5.0 & 5.0 & 5.0 & 5.0 & 5.0 \\
\hline $\begin{array}{l}\text { CONSTRUCTION } \\
\text { LABOR }\end{array}$ & 8.0 & 8.0 & 8.0 & 6.0 & 6.0 & 6.0 \\
\hline $\begin{array}{l}\text { CGNSTRUCTION } \\
\text { MPTERIALS }\end{array}$ & .7 .0 & 6.0 & 6.0 & 6.0 & 6.0. & 6.0 \\
\hline $\begin{array}{l}\text { CONSTRUCTION } \\
\text { COMPOSITE } \\
.\end{array}$ & 7.3 & 6.7 & 6.7 & 6.0 & 6.0 & 6.0 \\
\hline $\begin{array}{l}\text { OPERATIONS } \\
\text { LABOR }\end{array}$ & 8.0 & 7.0 & 7.0 & 7.0 & 7.0 & 6.0 \\
\hline $\begin{array}{l}\text { OPERATIONS } \\
\text { COMPOSITE }\end{array}$ & 7.4 & 6.4 & 6.4 & 6.4 & 6.4 & 6.0 \\
\hline $\begin{array}{l}\text { FUEL } \\
\text { (PRIMARY) }\end{array}$ & 6.0 & 6.0 & 6.0 & 6.0 & 6.0 & 6.0 \\
\hline $\begin{array}{l}\text { No. } 6 \\
\text { FUEL OIL }\end{array}$ & 6.0 & 6.0 & 6.0 & 6.0 & 6.0 & 6.0 \\
\hline
\end{tabular}

Escalation rates are expressed in percentage points.

$$
4-55
$$


TABLE $\quad 4-2$

NUCLEAR FUEL CYCLES

CASH FLOW - \$1,000's

FUEL CYCLE NUMBER

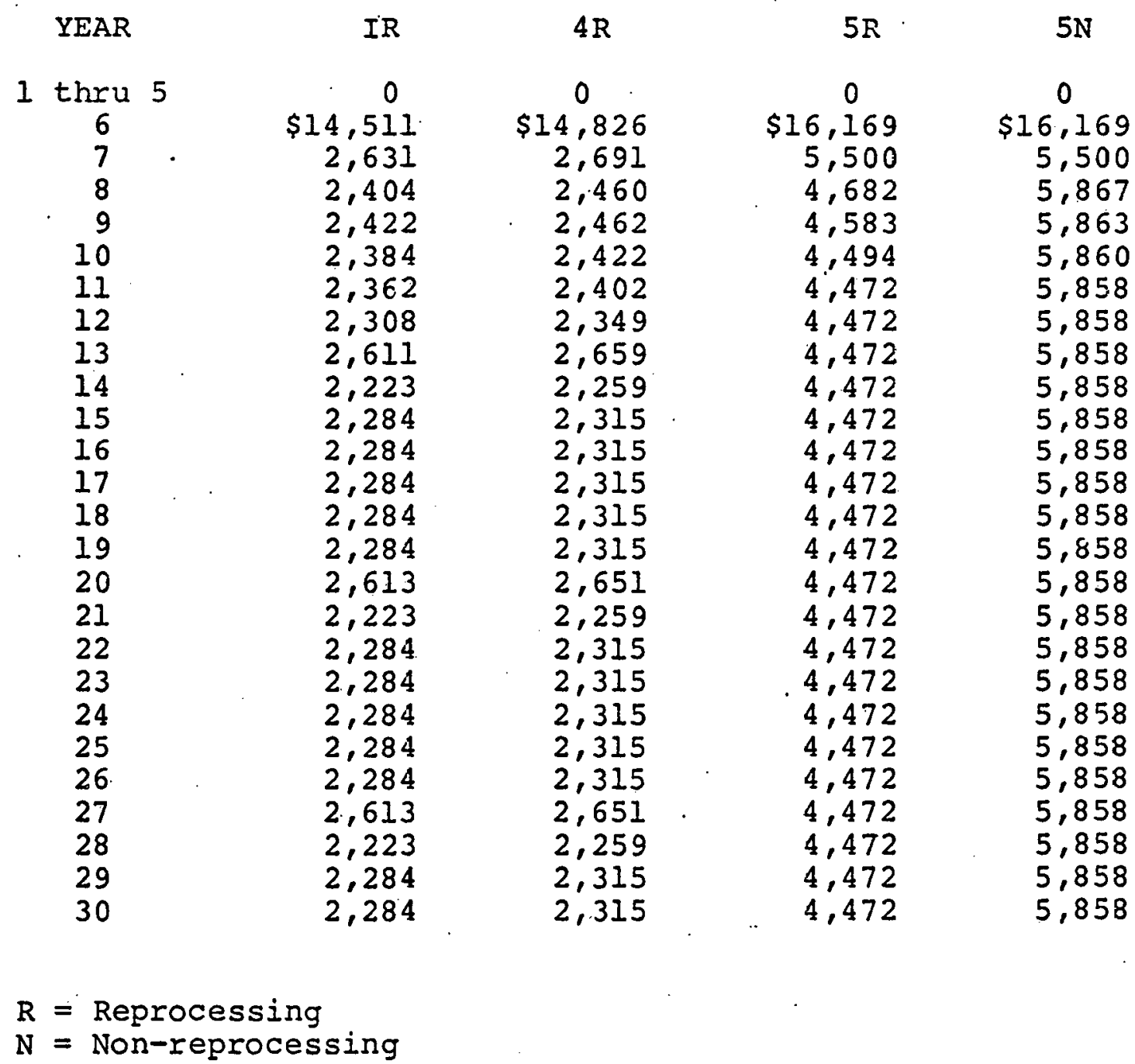

BASE DATE - January 1, 1978 


\section{TABLE $4-3$}

365 MWt PE-CNSG STUDIES

LAND NND IAND RIGIITS

$\mathrm{X}$

STRUCIUIR:S AND INPROVEIENTS

YARD WORK

$\mathrm{X}$

CONTAINNENT STRUCTURE

SUBSTRUCTURE

SUPERSTRUCTURE

CONCRETE SHIELDING

STEEL CONTAINIENT AND CONPONENTS

BUILDING SERVI.CES

REACTCR CONPART:ENT VENTILATION SYSTEM

CONTA INNENT DRY WELL COOLING SYSTEM

POST LOCA COIRUSTIBLE GAS CONTROL SYSTEM

LIGHTING AND SERVICE WIRING

LICHTING AND SERVICE NTRING

REACTOR SERVICE BUṬLIING

$x$

CONTROL BUILDING

$\mathrm{X}$

DIESEL. GENERATOR AND FUEL OIL BUILDING

$\mathrm{X}$

ADMINISTRATION BUILDING

$\mathrm{X}$

PROCESS BUILDING

$\mathrm{X}$

PROCESS HEAT SERVICE BUILDING. • . $\quad \cdot \quad \mathrm{X}$

WATER TREATMENT BUILDING $\quad \mathrm{X}$

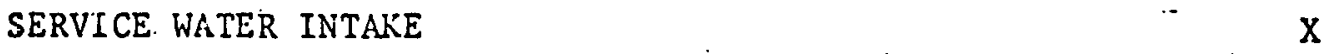

\section{REACTOR PLANT EQUIPIIENT}

RQEACTOR EQUIPIENT

EQUIPMLNT SONPONENTS

REACTOR VESSEL SHELL, HEAD, INTERNALS

STEAM GENERATORS

PRIMARY PUNPS (INC1. HEAT EXCHANGER, SERVICE AND MAINTENANCE TOOLS)

INSUIATION (REACTOR VESSE)

REACTOR CONTIOI, EQUIPNEN'T

CONTKOL RONS MND CONTROL ROD DRTVES

HANDLING EQUIPNENT (HENU STORICE STAND AND INTERNALS

HANDLTNG EQUTPNENT)

FIELD INSTALLATION OF ALL REACTOR EQUIPMENT

$\mathrm{x}$

$\mathrm{X}$

$\mathrm{X}$

$\mathrm{X}$

$x$

$\mathrm{X}$ 
REACTOR COOL.AN'T SYSTEH

EQUJPMLIIT COMPOHENTS

PRESSSURIZER AND IIEATERS.

PRE:SURIZER SURCE AND SPRAY LINE

PRESSURIZER RLLIEF LINE

PRESSURIZER RELIEF VALVES

INSULATION (PRESSURIZER, NND SURGE, SPARY AND RELIEF $\mathrm{X}$

LINES)

FIELD INSTALLATION OF ALL REACTOR COOLANT SYSTEM $X$

SAFEGUARDS COOLING SYSTEMS

DECAY HEST REYOVNL SYSTEM

DECAY HEAT REHOVAL PURE'S

DECAY HEAT REMOVAL HEAT EXCHANGER

PIPING AND VALVES

INSULATION

FIELD INSTALLATION OF DECAY HEAT REMOVAL SYJTEM

$x$

$\mathrm{x}$

$x$

$\mathrm{X}$

EMERGENCY DECAY HEAT RENOVAL SYSTEM

EMERGENCY DECAY HEAT REYOVAL PURPS

PIPIITG AND VALVES

INSULATION

FIELD INSTALLATION OF ENERGENCY DECAY HEAT

$x$

$\mathrm{X}$

$\mathrm{X}$

$\mathrm{X}$

$\mathrm{X}$.

REMOVAL SYSTEM .

RADIOACTIVE WASTE TREATIENT AND DISPOSAL SYSTENS

LIQUID WASTE DISPOSAL SYSTEM

ALL EQUIPNENT

PIPING AND VALVES

INSULATION

FIELD INSTALLATION OF LIQUID WASTE DISPOSAL SYSTEM $\mathrm{x}$

GASEOUS WASTE DISPOSAL SYSTEM

ALL EQUIPNENT

PIPING AND VALVES

INSULATION

FIELD INSTALLATION OF GASEOUS WASTE DISPOS $/ \perp \cdots \cdots$ SYSTEN

SOLID WASTE DISPOSAL SYSTEM

NLL EQUIPNENT

PIPING AND .VALVES

INSULATION

FIELD INSTALIATION OF SOLID WASTE DISPOSAL SYSTEM

$x$

$x$

$\mathrm{X}$

$X$

NUCLEAR FUEL HANDLING AND STORAGE SYSTENS

NLL EQUIYPIENT

PIPING $\Lambda N D$ VALVES

INSULATION

FIELD INSTALLATION OF NUCLEAR FUEL HANDLING AND

$\mathrm{x}$

$x$

$\mathrm{X}$

$x$

STORAGE SYSTENS 
NITROGEN NWD IIYDROCEN GAS SYSTEN

ALL EQUTPMENT

PIPING

FIELD INSTALLATION OF NITROCEN AND GAS SYSTEM

$\mathrm{X}$

$\mathrm{x}$

$\mathrm{X}$

COOLANT PURIFICATION AND CHEMICAL TREATMENT SYSTEMS

MNKEUP AND PURIFICATION SYSTEM

HAYEUP TANK

MAKEUP PURTS AND YOTORS

PURIFICATION DEMINERILIZERS

BORATED WATER STORAGE TANK

FILTERS

LETDONN COOLERS

PIPING NND VALVES

INSULATION

FIELD INSTALLATION OF MUKEUP AND

PURIFICATION SYSTEM

CHEMICAL ADDITION AND BORON RECOVERY SYSTEN

R-C BJ,EED HOLD-UP TANKS

R-C BLEED EVAPORATOR DISTILLATE TEST TANKS

CONCENTRATED BORIC ACID STORAGE TANKS

BORIC ACID MIX TANK

BORIC ACID ADDITION TANK

CAUSTIC MIX TANK

LITHIUN HYDROXIDE MIX TANK

R-C BLEED EVAPORATOR FEED PIRPS

R-C DISTILLATE TRANSFER PUNPS

R-C BLEED - EVAPORATOR DISTILLATE TEST TANK PUNPS CAUSTIC PLRP

CHEMICAL ADDITION PURP

DEBORATION DEMINERALIZERS

DISTILLATE DEMINERALIZERS

R-C BLEED EVAPORATOR DEMINERALIZERS

R-C DEGASIFIER PACKAGE

R-C BLEED EVAPORATOR PACKAGE

BORIC ACID BIN AND SCREN CONVEYOR

BORIC ACID FILTERS

MAKEUP AND PURJIICATION DEMINERALIZERS

PIPING AND VALVES

INSUL $A T I O N$

FIELD INSTALLATION OF CHEMICAL ADDITICN AND BORON RECOVERY SYSTEN

$\begin{array}{ll} & \mathrm{X} \\ & \mathrm{X} \\ \mathrm{X} & \mathrm{X} \\ & \mathrm{X} \\ & \mathrm{X} \\ \mathrm{X} & \\ \mathrm{X} & \\ \mathrm{X} & \end{array}$

$\mathrm{X}$

$\mathrm{X}$

$x$ 
PIPJING ANI) VALVES

INS ULATION

FIELD INSTALLATION OF COMPONENT COOLING WATER

$\mathrm{X}$
$\mathrm{X}$
$\mathrm{X}$ SYSTEH

MISCELIANEOUS PLANT EQUIPMENT

DEMINERALIZED WATER STORAGE TANK

EQUIPNENT AND FLOOR DRAINS COLLECTION TANK

DEMINEPALIZER FLUSH 'TANK

CASK DECONTAMINATION DRAIN COLLECTION TANK

DEMINERALIZER FLUSII TANK PUMPS

CASK DECONTAMINATION DRAIN PUNP AND MOTOR

CASK DECONTAMINATION DRAIN COLLECTION FILTER

SAIPLE COOLERS

PIPING AND VALVES

INSULATION

FIELD INSTALLATION OF MISC. PLANT EQUIPMENT

$\mathrm{x}$

$\mathrm{x}$

$x$

$\mathrm{x}$

$x$

$x$

$x$

$\mathrm{X}$

$x$

$\mathrm{x}$

MISCELLANEOUS SUSPENSE ITENS

FINAL ALIGNMENT AND CHECKING, FIELD PAINTING, QUALIFICATION OF WELDERS, STANDBY LABOR DURING

$x$ STAR'TUP :

ULTINATE HEAT SINK EQUIPAENT, PIPING, VALVES, IISSULATION AND $\mathrm{x}$ FIELD INSTALLATION

$\mathrm{X}$ MAKEUP WATER PIPING AND VALVES AND FIELD INSTALLATION

SERVICE WATER SYSTEM

EQUIPMENT, PIPING, VALVES, INSULATION AND . $\mathrm{X}$ FIELD INSTALLATION MAKEUP WATER PIPING AND VALVES AND FIELD INSTALLATION

INSTRURENTATION AND CONTROLS

NSS INSTRURENTS AND CONTROLS

INSTRUNENT PIPING AND TUBING

FIELD INSTALLATION OF INSTRUNENTATION AND CONTROLS

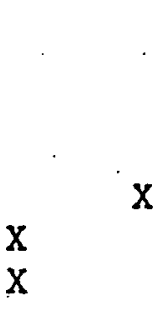

PROCESS ENERGY EQUIPNENT

SECONDARY SYSTEM

REBOILLRS

FEED IIEATERS

PURLFICATION ION EXCILNGIS

COOLEKS

SECONDARI FEI:D PUMPS

BLECTRO MAGNETIC FILTERS

DLAIN TANK

MOISTURE SLYARATORS

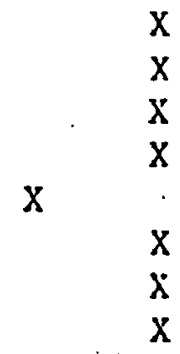


CIIESII CAL ADDITIOH EQUTPHEN'T

PIPING NND VALVES

INSUI, ATION

INSTRUYENTATION

FILLD INSTALLATION OF SECONDARY SYSTEM

$\mathrm{X}$

$\mathrm{X}$

$\mathrm{x}$

$\mathrm{X}$

TERTI ARY SYSTEM

FEED AND PROCESS RETURN PUMPS

DENERATOR

SUPERHEATER (InCl. FUEL SUPPLY SYSTEM)

PIPING AND VALVES - INSIDE PROCESS BLDG.

- FRON PROCESS BLDG TO USER'S PISANT

INSULATION - INSIDE PROCESS BLDG.

- FROM PROCESS BLDG. TO USER'S PLANT

FIELD INSTALLATION - INSIDE PROCESS BLDG.

- FROM PROCESS BLDG. TO USER'S.

\section{PLANT}

INSTRUSENTATION

$\mathrm{X}$

$\mathrm{X}$

$\mathrm{X}$

$x$

$x$

$\mathrm{x}$

$\mathrm{x}$

$\mathrm{X}$

$\mathrm{X}$

$\mathrm{X}$

TURBINE - GENERATOR SYSTEM

EQUIPIENT

PIPING AND VALVES

INSULAT ION

INSTRUNENTATION

FIELD INSTALLATION OF TURGINE - GENERATOR SYSTEH . $\cdot \mathrm{x}$

ELECTRIC PLANT EQUIPNENT

SIITCH GEAR

STATION SERVICE EQUIPIENT (Incl. T-G's and D-G's) , X

SWITCHBOARDS

PROTECTIVE EQUIPRINT. . . X X

ELECTRICAL STRUCTURES AND WIRING CONTAINERS $\quad \mathrm{X}$

POWER AND CONTROL. WIRING - .

MISCELLANEOUS PLANT EQUIPMENT

TRANSPORINTION AND LIFTING EQUTPNENT X X

AIR, WATER AND STEAM SERVICE SYSTENS $\cdot \cdot \mathrm{X}$

COMMUNICATIONS EQUIEMIENE

FURNISHINGS AND FIXTURES

$\mathrm{X}$

$\mathbf{x}$

$x$

$X$
$X$
$X$
$X$ 
UNDISTRIYUTED COST

ENGIMLERING MID HOME OFHICE SERVICES NUCLEAR PLANT

BALANCE-OF-PLAN'T

FIELD SUPERVISION, QUALITY CONTROL NIVD JOB OFFICE

$$
\begin{aligned}
& x \\
& x
\end{aligned}
$$
EXPENSE

TERPORARY FACILITIES

CONSTRUCTION EQUIPSTINT

CONSTRUCTION SERVICES

OTHER PLANT COST

LICENSING AND PUBLIC RELATIONS EXPENSE, OPERATOR TRAINING AND SPARE PARTS

$\begin{array}{ll} & X \\ X \\ X \\ X \\ X\end{array}$


2NBLS 4-A

PE-OASO CAPITAL COST ESTIMATES

(02,000\% - BA3E JANUARY 1. 1978

\begin{tabular}{|c|c|c|c|c|c|c|c|c|c|c|c|c|c|c|c|}
\hline \multirow[t]{2}{*}{. } & \multicolumn{15}{|c|}{ c A s $=$} \\
\hline & \multicolumn{3}{|c|}{1} & \multicolumn{3}{|c|}{2} & \multicolumn{3}{|c|}{3} & \multicolumn{3}{|c|}{.4} & \multicolumn{3}{|c|}{ s } \\
\hline \multirow{4}{*}{$\begin{array}{l}\text { PROCESS STEAM } \\
\text { DESTYG CONDITIONS }\end{array} \begin{array}{l}\text { FLOW } \\
\text { PRESSURE } \\
\text { TEMPERATURE }- \text { PSIGR }\end{array}$} & \multirow{2}{*}{\multicolumn{3}{|c|}{$\begin{array}{r}810,000 \\
550 \\
750 \\
0\end{array}$}} & \multirow{2}{*}{\multicolumn{3}{|c|}{$\begin{array}{r}1,000,000 \\
550 \\
750 \\
0\end{array}$}} & \multirow{2}{*}{\multicolumn{3}{|c|}{$\begin{array}{c}810,000 \\
550 \\
474^{\circ} \\
0\end{array}$}} & \multirow{2}{*}{\multicolumn{3}{|c|}{$\begin{array}{c}1,288,000 \\
550 \\
478 \\
0\end{array}$}} & \multirow{2}{*}{\multicolumn{3}{|c|}{$\begin{array}{r}1,000,000 \\
550 \\
750 \\
31\end{array}$}} \\
\hline & & & & & & & & & & & & & & & \\
\hline & \multicolumn{15}{|c|}{ ESTIMATES } \\
\hline & CNSG & $\begin{array}{l}\text { SUPER- } \\
\text { HEATER } \\
\text { PROCESS } \\
\text { INTER- } \\
\text { FACING } \\
\end{array}$ & $\begin{array}{l}\text { SUB- } \\
\text { TOTALS }\end{array}$ & CNSG & $\begin{array}{l}\text { SUPER- } \\
\text { MEATER } \\
\text { PROCESS } \\
\text { INTER- } \\
\text { FACING } \\
\end{array}$ & $\begin{array}{l}\text { Sur- } \\
\text { TOTALS }\end{array}$ & CNSG & \begin{tabular}{|l|} 
SUPER- \\
HEATER G \\
PROCESS \\
INTER- \\
FACING \\
\end{tabular} & $\begin{array}{l}\text { SUP- } \\
\text { TOTALs }\end{array}$ & CNSG & \begin{tabular}{|l|} 
SUPER \\
HEATER \\
PROCESS \\
INTER- \\
FACIIS \\
\end{tabular} & $\underset{\text { SOIALS }}{\text { Tors }}$ & CwSG & \begin{tabular}{|l|} 
SUPER \\
HEATER \\
PROCESS \\
INTER- \\
EACISOC \\
\end{tabular} & SUB- \\
\hline LANO & 96 & --- & 96 & 96 & --- & 96 & 96 & ---- & 96 & 96 & --- & 96 & 96 & --- & $9 \epsilon$ \\
\hline STRUCTURES AND IMPROVEHENTS & 23,921 & 684 & 24.605 & 23,972 & 684 & 24,656 & 23,921 & 634 & 24,555 & 24.022 & 634 & 21,636 & 24,264 & 863 & 25.127 \\
\hline REACTOR PLANT & 58,682 & ...- & 58,682 & 58,682 & --- & 58,682 & 58,682 & --- & 58,682 & 58,682 . & -- & 58,682 & 58,682 & $\cdots$ & 58.682 \\
\hline TURBINE PLANT & --- & --- & $\cdots$ & --- & $\cdots$ & $\cdots$ & --- & --- & --- & $\cdots$ & $\cdots$ & --- & 6,346 & -- & 6.346 \\
\hline $\begin{array}{l}\text { SECONDARY/TERTIARY/SUPERHEATER } \\
\text { SYSTEMS }\end{array}$ & 3.027 & 4.778 & 7,805 & 3.641 & 5,201 & 8,742 & 3.027 & 3.091 & 6.118 & 0,244 & 3,091 & 7.335 & 3.975 & 5.101 & 9.076 \\
\hline ELECTRICL PLANT & 7.466 & $:-\cdots$ & $\therefore 7,166$ & 7,466 & $\cdots$ & 7,466 & 7,466 & --- & 7.466 & 7,466 & --- & 7,466 & 8,801 & 1,093 & 9,974 \\
\hline MISCELLLANEOUS PLANT EQUIPKENT & 2.978 & $\cdots$ & 2,978 & 2,978 & -- & 2.978 & 2.978 & --- & 2.978 & 2,978 & --- & $.2,978$ & 3,122 & $\cdots$ & 3,122 \\
\hline OTHER COSTS & 2,200 & $-\infty$ & 2,200 & 2,200 & $-\cdots$ & 2.200 & 2.200 & $\cdots$ & 2,200 & 2,200 & --- & 2.200 & 2,500 & $\cdots$ & 2.500 \\
\hline UNDISTRIBUTEO COSTS & 16,090 & $\underline{1,111}$ & 27.201 & 16,090 & $\underline{1,176}$ & $\underline{17,266}$ & $\underline{16,090}$ & 764 & $16,054^{\circ}$ & $\underline{16,090}$ & 764 & 16.859 & 17,250 & 1,430 & 18,680 \\
\hline SUBTOTAL & 114.460 & 6.573 & 1221,033 & 125,125 & 6,961 & 122,086 & 114,460 & 4,189 & 118,949 & 115,758 & 1,489 & 120,217 & 125,116 & 0.487 & 133,603 \\
\hline $\begin{array}{l}\text { CONTINGENCY } \\
\text { TOTAL ESTIMATE }\end{array}$ & 6,327 & 667 & $\begin{array}{r}6,994 \\
128,027\end{array}$ & 6.414 & 705 & $\begin{array}{r}7,119 \\
129,205 \\
\end{array}$ & 6.327 & ${ }^{458}$ & $\frac{6.785}{225,734}$ & 6.484 & 458 & $\begin{array}{r}6,942 \\
127,289 \\
\end{array}$ & 7.426 & 858 & $\begin{array}{r}8,28: \\
141,807 \\
\end{array}$ \\
\hline
\end{tabular}

saturated steai 
TABLE 4-5

COAL PLUNE CAPITAL COSE EGTIMITES

(\$2,000's - GASI JNAUARY 2, 2978)

\begin{tabular}{|c|c|c|c|c|c|c|c|c|c|}
\hline \multirow{2}{*}{. } & & \multicolumn{8}{|c|}{ CAs 8} \\
\hline & & 1 & 2 & 3 & • & 5 & 6 & , & • \\
\hline $\begin{array}{l}\text { PROCESS STERM } \\
\text { DESICAN CONDITIONS }\end{array}$ & 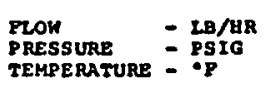 & $\begin{array}{r}1,000,000 \\
5550 \\
750\end{array}$ & $\begin{array}{r}1,000,000 \\
550 \\
750\end{array}$ & $\begin{array}{r}1,000,0000 \\
550 \\
790\end{array}$ & $\begin{array}{r}1,000,000 \\
550 \\
750\end{array}$ & $\begin{array}{r}1,000,000 \\
550 \\
750\end{array}$ & $\begin{array}{r}2,000,0000 \\
550 \\
750\end{array}$ & $1,000,0000$ & $1,000,0000$ \\
\hline $\begin{array}{l}\text { OESTCN POWER . CENEAT } \\
\text { TYPE OF CONL }\end{array}$ & rrow Mn (GRoss) & HIGH sULPUR & Lon sirfur & $\begin{array}{l}30.4 \\
\text { HICH SULPUS }\end{array}$ & LOW SULFUR & $\begin{array}{l}25 \\
\text { AICH SULPUR }\end{array}$ & $\begin{array}{l}25 \\
\text { LOW SULFUR }\end{array}$ & $\begin{array}{l}\text { 51.5 } \\
\text { HICH SURPUR }\end{array}$ & $\begin{array}{l}51.5 \\
\text { LOW SULPUR }\end{array}$ \\
\hline
\end{tabular}

\begin{tabular}{|c|c|c|c|c|c|c|c|c|}
\hline \multirow[b]{2}{*}{ LAND } & \multicolumn{8}{|c|}{ ESTIMATES } \\
\hline & S $\quad 400$ & - 100 & s 400 & $\$ \quad 100$ & $\$ \quad 100$ & $\$ \quad 100$ & $8 \quad 100$ & 400 \\
\hline SITEHORK & 1,225 & 1,125 & $1,1.25$ & 1,125 & 1,125 & 1,125 & 1,125 & 2,225 \\
\hline BUILDINGS AND STRUCTURES & 283 & 183 & 283 & 203 & 283 & 283 & 203 & 283 \\
\hline COAL YARD & 8.767 & 8,747 & 0.747 & 8.747 & 8,747 & 8.747 & 8.747 & 8,747 \\
\hline STEAM GENERATOR & 25,650 & 25,560 & $25.050^{\circ}$ & 25,560 & 17,500 & 16,450 & 17.500 & 16.450 \\
\hline TURA INE-GENERATOR & --- & $\cdots$ & 4,010 & 4.410 & 3.631 & 3,359 & 6.320 & 6,310 \\
\hline PROCESS MECHANICAL RQULPMEAT & 4.584 & 5.057 & 5.534 & 6,000 & 4,731 & 5,231 & 5,664 & 6.074 \\
\hline eLrctracis & 3,088 & 3.215 & 4.460 & 4.457 & 4.236 & 4.233 & 4.866 & 4.863 \\
\hline CIVIL-STRUCTURAR & 732 & 588 & 921 & $m$ & 863 & 689 & 961 & 016 \\
\hline PROCESS PIPING AND YNSTRURENTATIOM & 3,998 & 3,998 & 4,387 & 4,387 & 6,549 & 4.549 & 4.034 & 4,834 \\
\hline FLUE GAS DESULFURIzATION FACILITIPS & 7.655 & --- & 7,655 & $\cdots$ & 8,220 & $-\cdots$ & 8,225 & $-\cdots$ \\
\hline UNDISTRYBUTED COSTS & 6,120 & 3,853 & 7,365 & 6,455 & 2,110 & 6,339 & 7,359 & $\geq, 464$ \\
\hline SUBTOTAL & - 52.282 & 3 12,626 & $.60,837^{\circ}$ & 52.491 & 861.403 & - 51,305 & 866,174 & $.37,266$ \\
\hline CONTINGENCY & 5.228 & 1,264 & 6,084 & $\underline{5,248}$ & 6,140 & 5,130 & 6,617 & 5,727 \\
\hline TOTAL ESTIMATB & S $\$ 37.510$ & - 16.890 & $5.66 .92 \mathrm{i}$ & 157.739 & 607.543 & . 56.035 & 322,791 & 662.993 \\
\hline
\end{tabular}




\section{TABLE $4-6$ \\ CRITERIA FOR FUEL CYCLE COSTS \\ (Source - ORNL)}

BASIC COSTS

$\underline{1 / 1,78 \text { DOLLARS }}$

$\mathrm{U}_{3} \mathrm{O}_{3}(\$ / \mathrm{Ib})$

CONVERSION COST

$(\$ / \mathrm{Kg})$

ENRICHMENT COST

( $\$ / S W U)$

TAILS CONCENTRATION

( $\mathrm{s}$ U-235)

FUEL RECOVERY COST

$(\$ / \mathrm{Kg}) \quad 196$

FISSILE PLUTON.IUM VALUE

$(\$ / g)$

WITH

REPROCESSING

43

3.80

3.80

100

100

0.25

0.25

$(\$ / \mathrm{Kg}) \quad 196$

$-\div-$

33

DISPOSAI

$(\$ / K g)$

WITHOUT

REPROCESSING

43

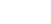

3

$--$

$-\infty$

1.00 
TABLE 4-7

COAL PRICE ESTIMATES

Wyoming Low-Sulfur Coal - 8,250 Btu/Lb

Illinois High-Sulfur Coal - 10,900 3tu/Lb

Rail Transportation

Coal cost at mine

Delivered Price
CosT - \$/MBtu

\begin{tabular}{lc}
$\frac{\text { COST }}{\text { WYOMING }}$ & ILIMINOIS \\
\hline .88 & $\$ .40$ \\
$\$ .47$ & $\$ .80$ \\
\hline
\end{tabular}

$\$ 1.35$

$\$ 1.20$

NOTE: These prices include all costs for delivered coal. It is assumed that the purchased does not own the unit train. 
TABLB $4-8$

PE-CNSG TOTAL ANNUAL EXPENSE ESTIMATES (LESS NUCLEAR FUEL*)

(\$1,00018 - BASE JANUARY 1, 1978)

PLANT AVAILABILITY 0.80

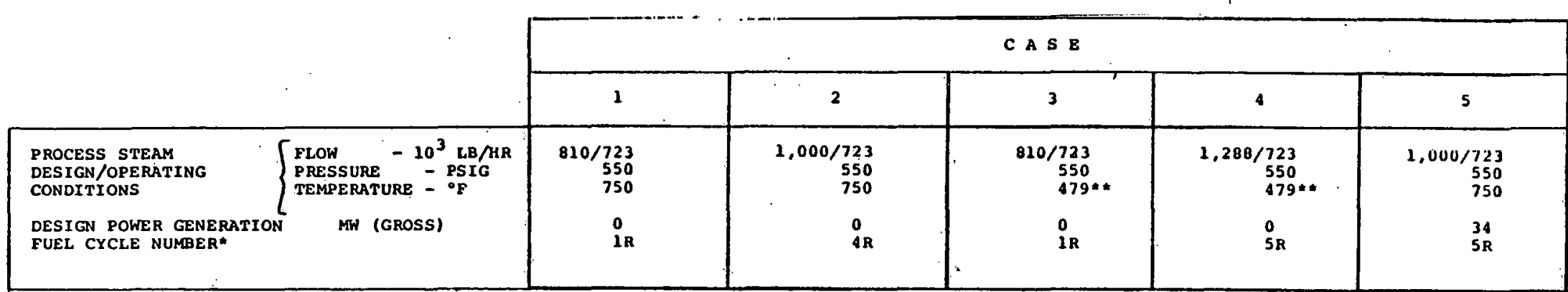

\section{STAFF}

MAINTENANCE MATERIAL.

SUPPLIES AND EXPENSES

GENERAL/ADMINISTRATIVE

NUCLEAR LIABILITY INSURANCE

NUCLEAR INSPECTION FEE

$$
\text { SUBTOTAL }
$$

POWER EXPENSE (CREDIT)

NO. 6 FUEL OIL FOR SUPERHEATING

TOTAL ESCALATING EXPENGB

(LESS NUCLEAR FUEL)

TAXES AND INSURANCE (FIXED)

TOTAL ANNUAL EXPENSE
(LESS NUCLEAR FUEL)

\begin{tabular}{|c|c|c|c|c|c|c|}
\hline \multicolumn{6}{|c|}{ B.STIMATES } & \multirow[b]{2}{*}{2,150} \\
\hline$\$$ & 2.100 & $\$ 2,100$ & $s: 1,935$ & $\$ 1,935$ & s & \\
\hline & 850 & 850 & 850 & 850 & & 850 \\
\hline & 325 & 325 & 325 & 325 & & 325 \\
\hline & 270 & 270 & 270 & 270 & & . 270 \\
\hline & 340 & 340 & 340 & 340 & & 340 \\
\hline & 22 & 22 & 22 & 22 & & 22 \\
\hline & 3,907 & 3,907 & 3,742 & 3,742 & & 3,957 \\
\hline & 1,245 & 1,245 & 1,245 & 1,245 & & $(5,419)$ \\
\hline & $\underline{2,707}$ & 2,742 & $\cdots$ & --- & & 2,742 \\
\hline & $\underline{7.859}$ & 2,894 & 4,987 & 4987 & & 2,280 \\
\hline & $\underline{1,792}$. & $\underline{1,809}$ & 1,760 & 2,781 & & $\underline{1,986}$ \\
\hline & $\underline{\underline{9.651}}$ & 9,703 & 6,747 & $\underline{\underline{6,768}}$ & & $\underline{3,266}$ \\
\hline
\end{tabular}

- See Table 4-2 for nuclear fuel cycle costs.

+ No. 6 Fuel Oil cost - $\$ 2.60 / \mathrm{MBtu}$ 


\section{TABLE $\underline{4-9}$}

\section{NUCLEAR PLANT OPERATTONS MANPOWER*}

NUMBER

PLANT MANAGEMENT:

PLANT MANAGER

ASSISTENT PLANT MANAGER

TECHNICAL ASSISTANTS

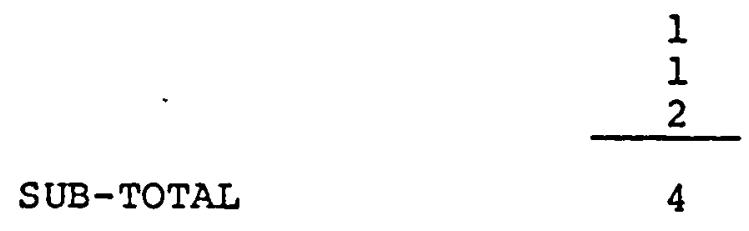

ADMINISTRATION :

OFFICE SUPERINTENDENT

CLERKS

STOCKMEN

ADDITIONAL SECURITY GUARDS

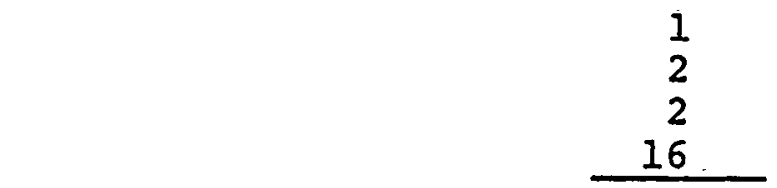

SUB-TOTAL

21

OPERATIONS :

SUPERINTENDENT

SHIFT SUPERVISORS

OPERATING SUPERVISORS

CONTROL OPERATORS

AUXILIARY OPERATORS

QUALITY ASSURANCE REPRESENTATIVE

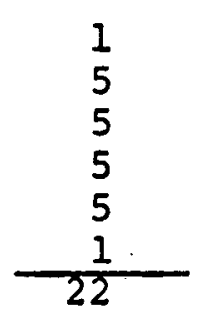

MAINTENANCE :

$$
\text { SUB-TOTAL }
$$

SUPERINTENDENT

FORMEN

MECHANICS

REPAIRMEN

REPAIRMEN HELPERS

UTILITY MEN

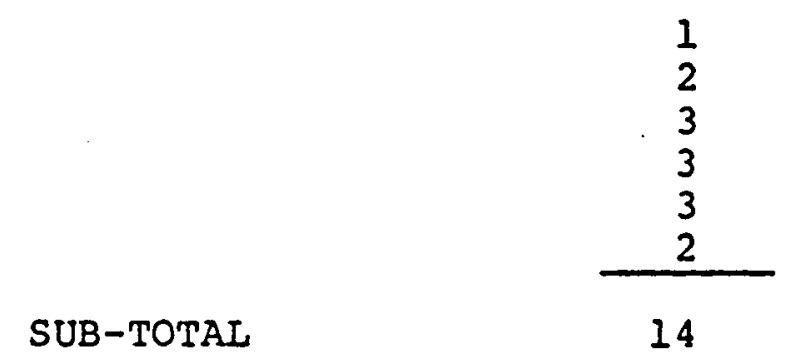




\section{TABLE $4-9$ cont'd.}

NUMBER

INSTRUMENTATION \& CONTROLS :

INSTRUMENT AND CONTROLS ENGINEER

TECHNICIANS

REPAIRMEN

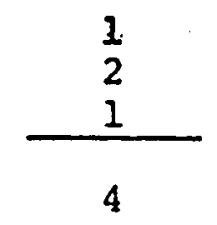

REACTOR ENGINEERING:

REACTOR ENGINEER

TECHNICAI ASSISTANT

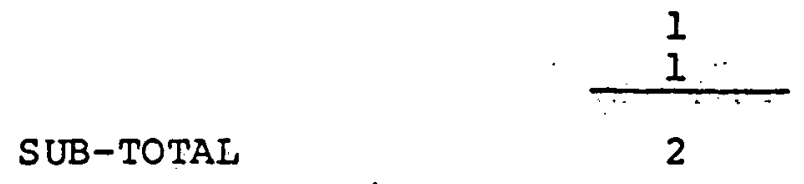

CHEMISTRY AND HEALTH PHYSICS:

RADIOCHEMICAI ENGINEER

SUB-TOTAL

TECHNICAL ASSISTANT

TECHNICIANS

RADIATION CONTROL HELPER

HEALTH PHYSICIST

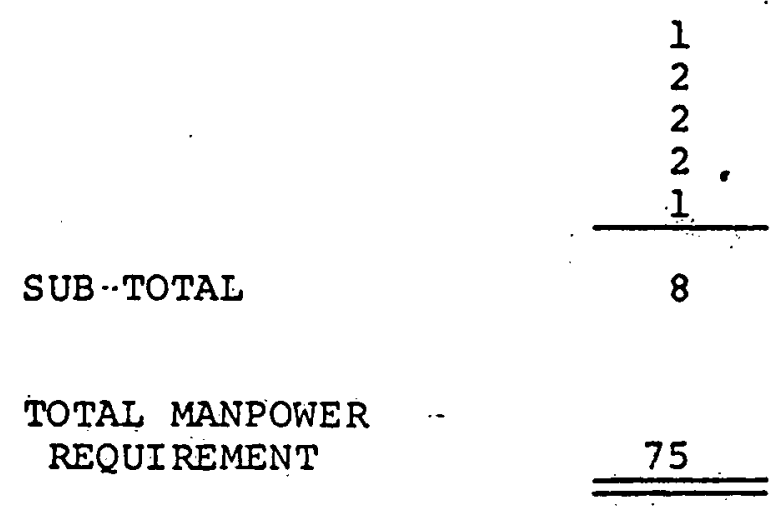

* Manpower for steam generation only. For nuclear cases 1,2 and 5 add 4 men for superheater operations. For case 5 add an additional 4 men for turbinegenerator operations. 
TABLE 4-10

BACKUP OPRRATING EXPENSES - \$1000's

NUCLEAR PLANTS (9)

\begin{tabular}{|c|c|c|c|}
\hline Case & 1 & $\begin{array}{l}\text { Years } \\
\text { Years }\end{array}$ & $\begin{array}{l}5-7 \text { (1) } \\
8-30\end{array}$ \\
\hline Case & 2 & $\begin{array}{l}\text { Years } \\
\text { Years }\end{array}$ & $\begin{array}{l}5-7 \text { (1) } \\
8-30\end{array}$ \\
\hline Case & 3 & $\begin{array}{l}\text { Years } \\
\text { Years }\end{array}$ & $\begin{array}{l}5-7 \text { (1) } \\
8-30\end{array}$ \\
\hline Case & 4 & $\begin{array}{l}\text { Years } \\
\text { Years }\end{array}$ & $\begin{array}{l}5-7 \\
8-30\end{array}(2)(3)$ \\
\hline Case & 4 & $\begin{array}{l}\text { Years } \\
\text { Years }\end{array}$ & $\begin{array}{l}5-7 \\
8-30\end{array}$ \\
\hline Case & & $\begin{array}{l}\text { Years } \\
\text { Years }\end{array}$ & $\begin{array}{l}5-7 \\
8-30\end{array}$ \\
\hline
\end{tabular}

COAL PLANTS (years 5-30)

Case 1

Case 2

Case 3

Case 4

Case 5

Case 6

Case 7 .

Caise 8
No. 6 FUEL OIL

(5) (7)

$\$ 21,373$

$8,0.59(8)$

21,373

$7,387(8)$

21,373

18,286

3,657

32,576

6,515

21,373

$7,387(8)$

(10)

$$
\$
$$

$\$ \quad 1,860$

1.860

1,860

1,860

1,860

1,860

1,860

1,860
POWER

(6)

$\$ 0$

0

$\$ 21,373$

8,059

21,373

7,387

21,373

5,352

$0 \quad 18,286$

$0 \quad 3,657$

0

32,576

6,515

0

21,373

7,387

NOTES:

(1) No. 6 Fuel not charged in years 5, 6, and 7 when coal and nucleas plants are assumed to start operation concurrently.

(2) Only concurrent construction start date case considered.

(3) Assumed 723;000 lb/hr saturated stean demand.

(4) Assumed 1,288,000 1b/hr saturated steam demand.

(5) No. 6 Fuel oil price $-\$ 2.60 / 10^{6} \mathrm{Btu}$.

(6) Backup power charged o $\$ 3.26 / \mathrm{KW} / \mathrm{MO}$. for peak gross electrical power generation over 15MW (Except coal cases 5 and 6 , where backup is calculated based on $0.8 \mathrm{x}$ peak).

(7) Backup fuel is sufficient to make up the difference between annual Btu produced and annual Btu required by Du Pont.

(8) Includes No. 6 fuel for superheating.

(9) Availability 0.80

(10) Availability 0.92

Base Date - January 1, 1978 
INBLE 1-21

COAT: PLANT SOTAE ANNUAL EXPENSE

(\$1,000' - BASE JANUARY 2, 1978)

PLANT RVALLAHILLTY - U.92

\begin{tabular}{|c|c|c|c|c|c|c|c|c|}
\hline & \multicolumn{8}{|c|}{$C A B=$} \\
\hline . & J. & 2 & 3 & 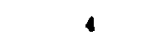 & 3 & 6 & 1 & 8 \\
\hline 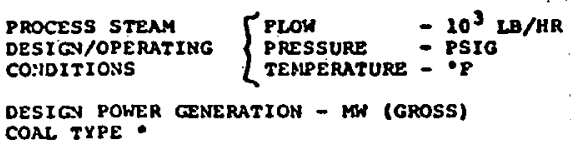 & $\begin{array}{r}1,000 / 723 \\
550 \\
750 \\
0 \\
\text { HIGH SULFUR }\end{array}$ & $\begin{array}{c}1.000 / 723 \\
550 \\
750 \\
0 \\
\text { LOH SULEUR }\end{array}$ & $\begin{array}{r}1,000 / 723 \\
550 \\
750 \\
30 / 4 \\
\text { HIGH SULFUR }\end{array}$ & $\begin{array}{r}1,000 / 723 \\
550 \\
750 \\
50 \\
\text { LOW SÚtFUR }\end{array}$ & $\begin{array}{c}1,000 / 723 \\
550 \\
750 \\
25 \\
25 \\
\text { HIGH SULFUR }\end{array}$ & $\begin{array}{r}i, 000 / 723 \\
550 \\
750 \\
25 \\
25 \\
\text { LOW SULPUR }\end{array}$ & $\begin{array}{r}1,000 / 723 \\
550 \\
750 \\
51.5 \\
\text { HIGH SULPUR }\end{array}$ & $\begin{array}{r}1,000 / 723 \\
550 \\
750 \\
51.5 \\
\text { LOW SULPUR }\end{array}$ \\
\hline
\end{tabular}

\begin{tabular}{|c|c|c|c|c|c|c|c|c|}
\hline STAFP & Is 1.780 & $1,54 \theta$ & 1,909 & I\$ 1,676 & 1,909 & 2,676 & 1,909 & $=1.676$ \\
\hline MAINTENANCE MitTERIAL & 600 & 502 & 700 & 640 & 320 & 620 & 820 & 711 \\
\hline LIMESTONE & 235 & --- & 326 & --- & 252 & -.. & 347 & --- \\
\hline ASH/SLUDGE DISPOSAL & 347 & 248 & 479 & 343 & 371 & 265 & 514 & 367 \\
\hline MISCELLANEOUS SUPPLIES & .2215 & 279 & 323 & 245 & 249 & 189 & 314 & 261 \\
\hline SUBTOTAL & 3,177 & $2,47 ?$ & 3,137 & $2,90,4$ & 3,501 & 2,750 & 3,904 & 3,015 \\
\hline POWER EXPENSE (CREDIT) & 1.804 & 1,603 & $(4,6.99)$ & $(4,366)$ & $(2,147)$ & $(2,362)$ & $(\theta, 611)$ & $(9,137)$ \\
\hline COAL EXPENSE & 2,011 & $\underline{10,342}$ & 12,455 & $\underline{14,305}$ & 9,649 & 11,083 & $\underline{13,3,66}$ & $\underline{15.330}$ \\
\hline TOTAL ESCNLATING EXPEMSS & $\underline{13,992}$ & 14.422 & $\underline{\underline{2,113}}$ & $\underline{12.843}$ & 11,003 & $\underline{11,471}$ & .8 .639 & 9,208 \\
\hline TAXES AND INSURANCE (FIXED) & 805 & 656 & 9.937 & 808 & 946 & 790 & 1,019 & $\underline{882}$ \\
\hline TOTAL ANNUAL EXPENSE & 14,797 & 15.078 & $\underline{13.050}$ & $13,651$. & $\underline{11,949}$ & $\underline{12,261}$ & 9,658 & 10.030 \\
\hline
\end{tabular}

- high sulfur coal cost - \$1.20/Matu; Lor sulfur coal cost - \$2.35/MBtu 
TABLE $4-12$

COAL PLANT OPERATIONS MANPOWER*

Number

MANAGEMENT STAFF :

- PLANT MANAGER

MECHANICAL ENGINEER

ELECTRICAL/INSTRUMENTATION ENGINEER

PURCHASING AGENT

WAREHOU SEMAN

PAYROLL CLERK

RECEPTIONIST/SECRETARY

1

1

1

1

1

SUB-TOTAL

5

MAIN CONTROI ROOM:

SUPERVISOR

1

OPERATORS :

BOILER

TURBINE-GENERATOR

INSTRUMENTATION

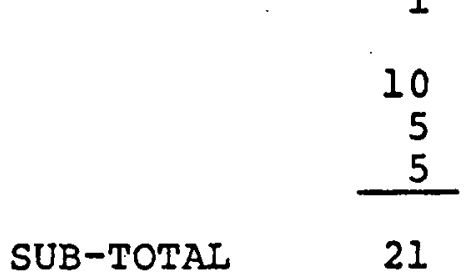

ROVING :

WATER TREATMENT

5

PRECIPITATOR/DUST COLLECTION

ASH HANDLING

COAL HANDIING :

SUPERVISOR

COAL RECEIVING AND STACKING

COAL RECLAIMING AND DELIVERY

ASH PONDS

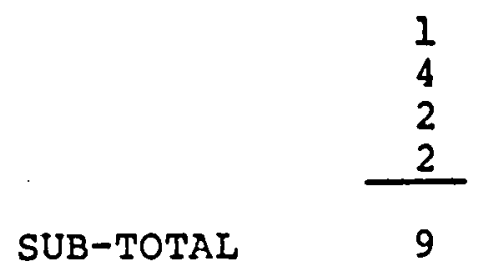


TABLE $4-12$ Cont'd.

Number

FLUE GAS DESULFURIZATION:

SUPERVISOR

LIMESTONE HANDLING

CONTROL ROOM

SLUDGE DISPOSAL

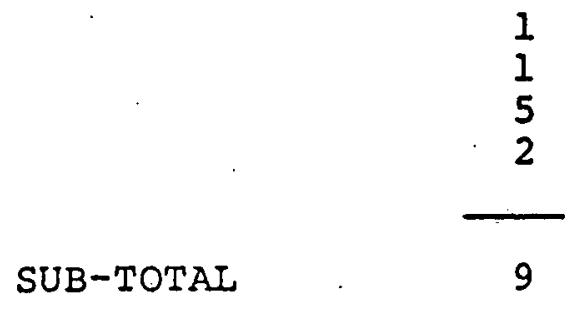

MAINTENANCE :

SUPERVISOR

PREVENTATIVE

STANDBY

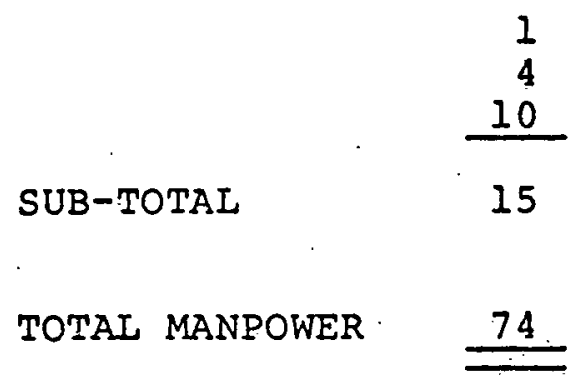

* INCLUDES MANPOWER FOR TURBINE GENERATOR AND FLUE GaS DESULFURIZATION FACILITIES. 


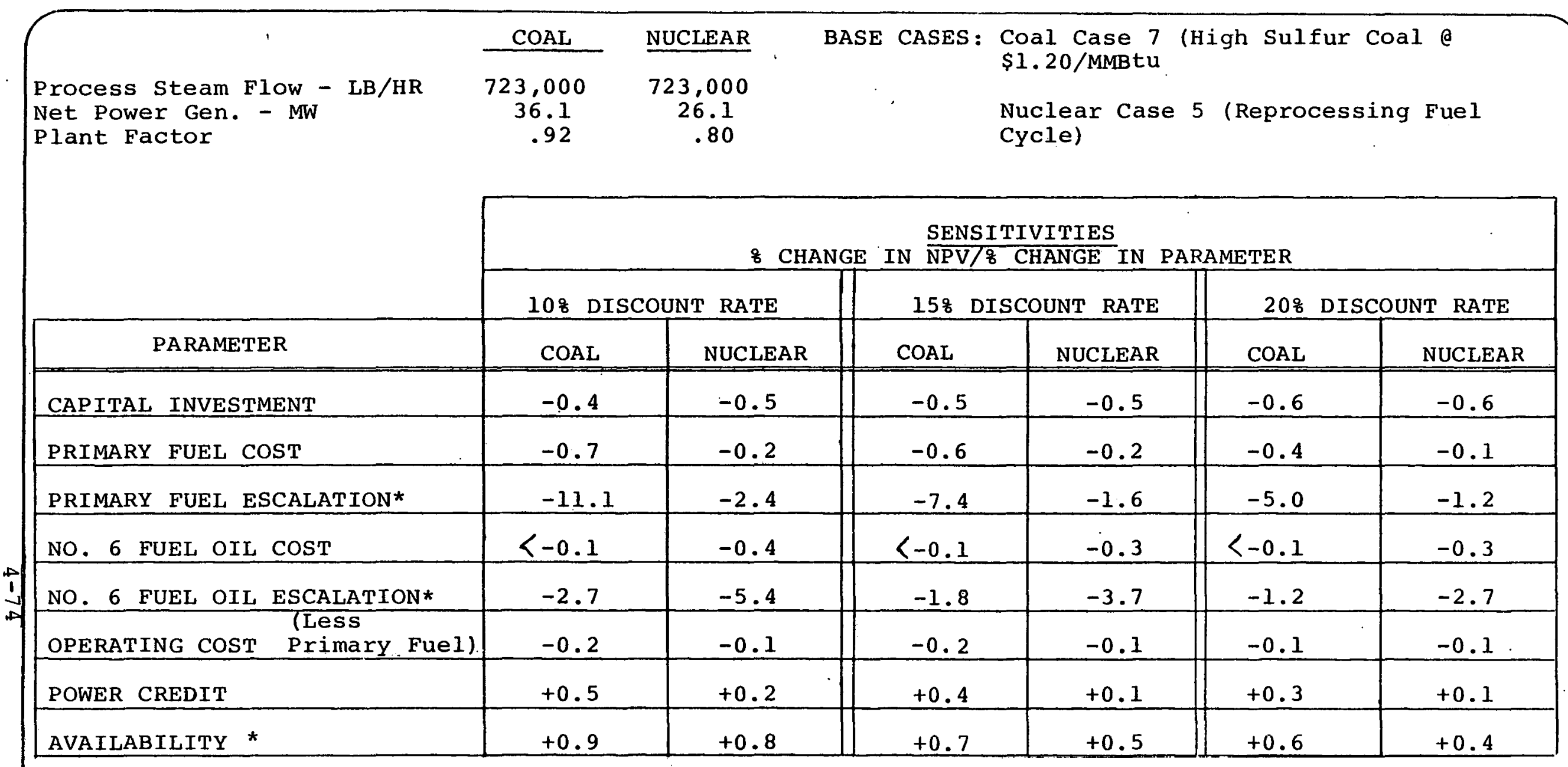

*PER. PERCENTAGE POINT

Example: A 1\% Increase in nuclear (primary) fuel cost results in a $0.2 \%$ Decrease in net present value at 158 discount rate.

TABLE 4-13 COMPARISON OF NET PRESENT VALUE SENSITIVITY TO ECONOMIC PARAMETER VARIATIONS 


\subsection{CONCLUSIONS}

\subsection{Site Feasibility}

This section treats the results of the preliminary evaluation of the suitability of the Du Pont site for siting a nuclear power plant such as the PE-CNSG. The objective of this evaluation was to identify gross site inadequacies, such as possible active faults, which could place very serious limitations on locating the PE-CNSG at the site and could lead to complex licensing problems and the associated substantially zigher costs that could accrue.

Although proper investigation of such potential inadequacies would require extensive field studies, it was felt that the stated objective could be met by a site visit and by examination of Du Pont's available geologic data. This has been accomplished, but the costs associated with site suitability studies and site preparation or remedial work, that might be revealed later by actual field investigations, have not been factored into the economic assessment.

As pointed out before, the objective of the site evaluation was to identify major geological inadequacies if any. Brief consideration was also given to some other site-related factors. The findings listed below are preliminary and are subject to future verification.

(1) No gross site characteristics were identified which would preclude locating a nuclear plant at the Du Pont site:

(2) From a licensing standpoint, surface faulting and subsidence are major geological considerations which will have to be addressed. Iiquifaction, however, should not be of concern because of the high density of the existing sands.

(3) As of now, there are no borings drilled at the proposed PE-CNSG location. However, considering the characteristics of the upper soils, only light or less important structures should be placed on these soils.

(4) According to available information, the overpressure that would result at the proposed CNSG site if the nearest storage container exploded would be approximately 0.01 psi. This is small, and the 24. inch diameter natural gas transmission pipeline running just south of the proposed CNSG site seems to be of more significance in estimating explosion overpressure. While an analysis is beyond the scope of the study, it is believed that the gas pipeline will not be a limiting factor in locating the CNSG plant at the Du Pont site. 


\subsection{Site Feasibility - (Continued)}

The physical requirements for nuclear plant siting are more restrictive than those for a conventional coal plant. Thus, the lack of apparent site difficulties affecting nuclear siting appears to ensure that there would be no problems in locating a coal plant physically on the site.

The licensing of a nuclear plant is based on safety considerations and analyses which demonstrate the even under conditions associated with the "design basis" loss-of-coolant accident and with a number of conservative assumptions, the reactor core will be adequately cooled and no fuel melting or fission product released will occur. Federal regulations (10 CFR Part 100), however, state that as an aid in evaluating a proposed site an applicant should assume a fission product release from the core together with containment leakage for the purpose of determining that the radiation dose to human individuals around the site is below certain values. The Nuclear Regulatory Commission requires further conservative ("worst case") assumptions for siting analysis, including lower radiation limits to humans plus conservative assumptions with respect to atmospheric dispersion and human inhalation. These conservative assumptions are designed to ensure that the reactor site will be such that radiation exposure to the population will be minimized in the event of an accident.

The results of the siting analysis determine the so-called "Exclusion Area" (EA) and the "Low Population Zone" (IPZ) to be associated with the nuclear plant site. The EA is the area surrounding the reactor in which the reactor licensee has the authority to determine all activities within the area, including removal of personnel and property. In selecting a site for a nuclear power plant, it is necessary to provide for an exclusion area in which the applicant has the authority to control activities within the area. This is typically accomplished by providing a fence with guards to monitor and control the personnel who enter the area.

The LPZ is an area that immediately surrounds the exclusion area in which the population number and distribution is such that there is a reasonable probability that appropriate measures could be taken in their behalf in the unlikely event of a reactor accident. A fence would not typically be used at the LPZ since this area can contain residential dwellings and occupants not under the control of the plant owner.

At a typical large electrical generating nuclear plant, the EA can. be as large as a circular area with radius of $0.4 \mathrm{mile,}$ and the LPZ as large as an area with a radius of 3 miles. Because of the small size and inherent safety features of the PE-CNSG, the radius of the LPZ was calculated to be 900 feet and the EA was calculated to be so small as to be virtually at the reactor building. This implies that 


\subsection{Site Feasibility - (Continued)}

an individual standing near the reactor building following a reactor accident would not receive a radiation dose in two hours that exceeds regulatory acceptable limits nor would a person standing at the LPZ boundary receive a radiation dose that exceeds safe limits even if he stands at the location for the entire duration of the activity release (usually assumed to be 30 days).

Due to the very low EA and LPZ distances that result from a PE-CNSG reactor accident, it is recommended for this site that the EA boundary be moved out to the 900-foot distance so that the EA and IPZ are the same. This implies that a fence would be placed around the reactor plant at a 900 foot radius with appropriate security guards to control and monitor personnel entering the site. Since the process plant then would be outside of the LPZ, even the worst assumed reactcr accident conditions should not interfere with continued operation of the plant with auxiliary steam.

From a radiation standpoint, it is concluded that the proposed plantsite will be acceptable for licensing based on the limited study performed.

\subsection{Economic Feasibility}

The case 5 nuclear plant is the optimun of the five nuclear plants studied under the established net present value (NR.V). criterion. This configuration is designed to meet Du Pont's stated process steam requirements and generates a $26.1 \mathrm{MW}$ of electrical power on a $26.1 \mathrm{MW}$ levelized annual basis.

The case 7 high-sulfur coal-fired plant is the optimum coal plant. The case 6 or case 8 low-sulfur coal-fired plants actually have slightly higher NPVs but do not include expenses for flue gas scrubbing, which most probably will be required. Therefore it has been concluded that the case 7 plant is more representative of a realistic alternative. The case 7 coal plant also satisfies Du Pont's process steam requirements, while generating 36.1 MW of electrical power on a levelized annual basis.

Under the assumptions in force for the study and for this particular application, it is concluded that the coal-fired plant is the economic choice for coal prices less than $\$ 2.00-\$ 2.20 / 10^{6} \mathrm{Btu}$ for the concurrent construction start date plants and less than $\$ 2.40-\$ 2.50 / 10^{6}{ }_{\mathrm{Btu}}$ for the concurrent operation start date plants.

The relatively high energy costs predicted for nuclear (compared to earlier estimates) arise from several factors. The average industrial steam load of $723,000 \mathrm{lb} / \mathrm{hr}$ amounts to only 56 f of rated reactor capacity, and while the excess steaming capacity is used to generate electricity, power generation does not provide sufficient net revenue to yield attra:tive overall steam production costs. For a. PE-CNSG producing steam only a rise in industrial steam load from 56\% to $100 \%$ of reactor capacity would lower steam cost by about $20 \%$. 


\subsection{Economic Feasibility - (Continued)}

Du Pont's requirement for superheated steam imposes an additional cost penalty on the PE-CNSG since a supplemental oil-fired superheater is required to elevate the reactor steam to about $7500 \mathrm{~F}$. Thus, oil provides about one-fifth of the energy consumed to produce process steam during normal operations. Superheating increases steam costs by about $10 \%$.

A PE-CNSG application for supplying base-load saturated steam to industry, either prime steam or via cogeneration; probably would be more attractive. Present results, project saturated steam costs of about $\$ 2 / 10^{6} \mathrm{Btu}$ in 1978 dollars for a $1,288,000 \mathrm{lb} / \mathrm{hr}$ constant steam demand and a $15 \%$ discount rate. Oil based superheat would increase the steam cost to about $\$ 2.20 / 106_{\mathrm{Btu}}$; this is roughly equal to the cost of superheated process steam from a case 7 coal-fired plant with a 0.85 plant availability factor and burning high-sulfur coal costing $\$ 1.70 / 10^{6} \mathrm{Btu}$, or $\$ 37 /$ Ton.

Sensitivity studies showed that the nuclear plant economics are less sensitive to fuel prices than the coal-fired plants.

Since the capital investments required for nuclear and coal plants are widely different, a NPV analysis may not provide sufficient economic information to allow a final choice to be made. However, a more detailed evaluation that considers company financing explicitly, is beyond the scope of the present study. It is expected that consideration of debt financing in place of equity financing would improve the economic outlook for the capital intensive nuclear option.

\subsection{Technical Feasibility}

All CNSG and coal-fired process steam generation systems studied are technically feasible. Both types of systems represent essentially state-of-the-art technology.

For the CNSG plants, the major technologically related uncertainty is the Nuclear Regulatory Commission's (NRC) Iicensing requirements. The CNSG application considered in this study would be a "First-of-akind" installation. As such, there is no direct precedent to guide the NRC in its licensing procedures. B\&W has expended considerable effort towards generic-type licensing of the reactor plant itself. Since the plant is an extension of previous marine applications and calls for no technological advances, and since the design appears to offer certain safety advantages, there is no reason to doubt its licenseability. 


\subsection{Technical Feasibility - (Continued)}

The coal plant poses no apparent problems from a technical licensing standpoint. Environmental standards may become more stringent in the future. However, as of the date of this study, all coal plants considered would be acceptable from an environmental standpoint in the Victoria, Texas, area if flue gases are scrubbed. 


\subsection{RECOMMENDATIONS}

This feasibility study has demonstrated that both the PE-CNSG and coal alternatives are feasible process steam generation systems for the Du Pont plant site at Victoria, Texas. The economic analyses have shown that, on an all-equity, net present value basis, the optimum PE-CNSG configuration is not competitive with the optimum coal plant configuration. Any future studies aimed at more fully defining PE-CNSG and coal plant economics should consider these aspects:

(1) Consider cost of capital in cash flow analyses. This is necessary due to the wide differences in capital investment required between the nuclear and coal plants.

(2) Study the economics of coupling the PE-CNSG to existing industrial plants that have been modified to accept saturated steam. This improves the economics of the PE-CNSG plant considerably, especially as the steam demands increases towards full PE-CNSG capacity.

(3) Consider alternative fuels for superheating, including waste or by-product fuels not currently fired to produce steam.

Item (1) will certainly be a factor in the final decision to proceed with any alternative steam supply system. The wide difference in capital required for a PE-CNSG plant relative to a coal-fired plant would have to be economically justifiable. The return on the differential capital investment for the more expensive alternative would have to be determined in light of a comparison to the alternative investment, with cost of capital included in the analysis. The effect of cost of capital becomes increasingly important as the amounts of capital investment become more highly unequal. The PE-CNSG offers potentially high savings in annual costs, but with its high capital investment, a complete economic picture can be obtained only with debt service costs included as a part of the economic analyses.

The PE-CNSG is a pressurized water reactor (PWR). A generic characteristic of PWRs is that they generate saturated or only slightly superheated steam. While superheating the PWR steam presents no real technical obstacle, it can have a significant impact on PE-CNSG economics for applications where superheated steam is required, depending on the fuel used. Thus, any further study ought to consider the economics of alternative superheater fuels and/or process plant modifications which would allow use of saturated steam. 


\section{REFERENCES}

1. "A Small pressurized Water Reactor for Process Energy" prepared by Babcock and Wilcox under contract to the Oak Ridge National Laboratory, Report No. BAW-1428 (ORNL/SUB-4390/2) June 1976 .

2. O. H. Klepper, I. C. Fuller, and M. L. Meyers, "Assessment of a Small Pressurized water Reactor for Industrial Energy", ORNL/TM 5881, October 1977.

3. "Comparison of Coal - and Nuclear-Fueled Alternatives for Process Steam and By Product Electrical Power Generation for the PPG Industries, Incorporated, Plant Site, Lake Charles, Louisiana", prepared by Power Systems Engineering under contract to Oak Ridge National Laboratory, ORNL/SUB-7257/8

4. "Duval Corporation Application Study, Nuclear Process Energy From PE-CNSG", prepared by Babcock \& Wilcox under contract to Oak Ridge National Laboratory BAW-1448, ORNL/SUB-4390/5 December, 1977. 